\title{
RESISTÊNCIA DE BIOTIPOS DE Brachiaria plantaginea (Link) Hitchc. A HERBICIDAS INIBIDORES DA ACETIL COENZIMA A CARBOXILASE
}

\section{MARLUCE GONÇALVES CORTEZ \\ Engenheira Agrônoma}

\author{
Orientador: Prof. Dr. RICARDO VICTORIA FILHO \\ Co-orientador: Prof. Dr. PEDRO JACOB CHRISTOFFOLETI
}

Tese apresentada à Escola Superior de Agricultura "Luiz de Queiroz", Universidade de São Paulo, para obtenção do título de Doutor em Agronomia, Área de concentração: Fitotecnia.

$\mathrm{P}$ i r a c i c a b a

Estado de São Paulo - Brasil

Maio - 2000 


\section{E R R A T A}

"A autora, após a experiência desta tese, comprovou que é difícílimo, senão impossivel evitar que, ao longo de aproximadamente 60.000 palavras, se deslizem algumas erratas. Apesar dos esforços para evitá-las e das correçōes efetuadas, a última leitura, já encadernada, revelou as erratas abaixo, algumas fundamentais, outras nem tanto, para as quais espero, que o bom critério dos leitores possa ressalvá-las."

\section{Página: Onde se lê:}

$\mathbf{v}$

viii $\quad$...planta daninha com menor tolerância...

...a herbicidas vários herbicidas...

$7 \quad$...2400 milhōes...

9 ...tiorcarbamatos...

11 Figura 3...

haloxyfop

13 (Walkil et al., 1993)

$15 \quad$...Konish \& Sasaki, 1994).

19 (Hoppe \& Zacher, 1982 e 1985)

21

23

24

26

28

31

32

38

40

41
...(Brezeu et al., 1976...)...

...(Hoppe, 1981...)...

...classes de herbicidas (Heap,1999).

Gressel \& Segel (1978)

(Hauler et al., 1991)

Final do $2^{\circ}$ parágrafo é início do $3^{\circ}$ parágrafo.

LeBaron (1988)

(Whitehead \& Switzer, 1963)

(Rubim, 1997)

...ou herbicidas com mecanismo

de ação...

...de aril-glucosídeo e menr...

(Hauler et al., 1991)

(De Prado et al., 1973)

\section{Leia-se:}

... e do fator de resistência de...

...planta daninha com maior tolerância...

...a vários herbicidas...

...2,4 bilhōes...

...tiocarbamatos...

Figura 1...

haloxyfop-methyl

(Walkil et al., 1983)

...Konishi \& Sasaki, 1994).

(Hoppe \& Zacher, 1982;

Hoppe, 1985)

...(Brezeanu et al., 1976...)

...(Hoppe, 1989...)...

...classes de herbicidas

(Heap, 1997).

Gressel \& Segel (1982)

(Hausler et al., 1991)

LeBaron (1982)

(Whitehead \& Switzer, 1962)

(Rubim, 1991)

..ou herbicidas com mesmo mecanismo de ação...

...de aril-glucosídeo e menor...

(Hausler et al., 1991)

(De Prado et al., 1997) 
Página: Onde se lê:

63 ...e quatro ciclohexanodionas...

...sendo que a maior taxa...

72

75

77

78

79

80

82

83

84

93

94

105

109

111

125

126

132

133

135

137

144

146

147

155

... o grau de resisitência...

...Freitas et al., 1993.

...fluazifop-p-butil...

... aplicados dissolvidos...

...determinação da taxa...

...Piracicaba/SP...

...Argilosa...

0,3

0,02

288,8

$3,9 \quad 15,6 \quad 62,5 \quad 250 \quad 10004000$

\section{8}

...(vide item 1.3)...

...taxa de resistência...

...(Kissmann \& Groth, 1991)...

...taxa de resistência...

...taxa de resistência...

...sethoxydim...

...fluazifop-methyl...

Os compostos...

...caráter resistente...

...item $2.2 \ldots$

...item $2.2 \ldots$

...item $2.2 \ldots$

...sethoxydim absorvido foi

aumentando...

...tepraloxydim que apresentou, após 48 horas...

...taxa de resistência...

...taxa de resistência...

...sethoxydim mostrou diferenças

significativas...

...COOETEC-201...

...(Durigan et al., 1983)...

...26 tratamentos...

...Tabela 2 ...

...taxa de resistência...

Tabela A2...

\section{Leia-se:}

..e três ciclohexanodionas... ...sendo que o maior fator... ... o fator de resisitência...

...Freitas et al., 1990.

...fluazifop-p-buthyl...

... aplicados diluidos...

...determinação do fator...

...Holambra/SP...

...Arenosa...

0,31

0,03

28,9

$\begin{array}{llll}15,6 & 62,5 & 250 & 1000\end{array}$ 400016000

$8 \quad 32$

...(vide item 1.2)...

...fator de resistência...

...(Kissmann, 1991)...

...fator de resistência...

...fator de resistência...

...butroxydim...

...fluazifop-p-butthyl...

As formulações...

...caráter de resistência...

...item 2.1.2...

...item 2.1.2...

...item $2.1 .2 \ldots$

...sethoxydim absorvido foi diminuindo...

...tepraloxydim foi reduzindo após 48 horas..

...fator de resistência...

...fator de resistência...

sethoxydim e tepraloxydim

mostraram diferenças

significativas...

...COODETEC-201...

...(Durigan, 1983)...

...24 tratamentos...

anexada no final!

...fator de resistência...

Tabela A1... 
REFERÊNCIAS BIBLIOGRÁFICAS - ACRESCENTAR:

Página 44:

BOGER, P.; SANDMAN, G. Target sites of herbicides action. R.C. Kirkwood ed.Plenum Press, New York. 1989. 415p.

BURGSTHALER, R.J.; LICHTENTHALER, H.K. Inhibition by sethoxydim of phospho- and galactolipid accumulation in maize seedlings. In: SIEGENTHALER, P. A.; EICHENBERGER, W. eds. Structure, function and metabolism of plant lipids. Elservier, Amsterdam. p. 619-622. 1984.

ASARE-BOAMAH, N. K.; FLETCHER, R. A. Physiological and cytological effects of BASF $9052 \mathrm{OH}$ on corn (Zea mays) seedlings. Weed Science v. 31, p. 49-55. 1983.

Página 46:

DE PRADO, R.; LOPEZ-MARTINEZ, N.; GIMENEZ-ESPINOSA,R. Herbicideresistant weeds in Europe: agricultural, phisiological and biochemical aspects. In: DE PRADO, R.; JORRÍN, J.; GARCIA-TORRES, L. eds. Weed and crop resistance to herbicides. Kluwer, Dordrecht. 1997. p. 17-28.

Página 47:

DEISENHOFER, J.; MICHEL, H. The photosyntetic reaction center from the purple bacterium Rhodopseudomonas viridis. Science v.245, p. 14631473. 1989.

Página 50:

HEAP, I. International survey of herbicide resisitant weeds. On line. Internet. www.weedscience.com. $6^{\text {th }}$ October. 1999.

Página 52:

HOPPE, H.H.; ZACHER, H. Inhibition of fatty biosynthesis in isolated bean and maize choloplast by herbicidal phenoxypropionic acid derivates and structurally related compounds. Pesticide Biochemistry and Physiology v. 24, p. 298-305. 1985.

LICHTENTHALER, H.K.; MEIER, D. Inhibition by sethoxydim of chloroplast biogenesis, development and replication in barley seedlings. Zeitschrift fur Naturforschung v. 39, p. 115-122, 1984. 
Página 53:

LUCAS, W.J.; WILSON, C.; WRIGHT, J.P. Perturbation of Chara plasmalemma transport finction by 2 (4 (2', 4'-dichorophenoxy) phenoxy) propionic acid. Plant Physiology v. 74, p. 61-66. 1984.

Página 56:

OLSON, W.A.; NALEWAJA, J.D. Antagonistic effects of MCPA on wild oat (Avena fatua) control with diclofop. Weed Science v.29, p. 566-571. 1981.

OWEN, W.J. Herbicides metabolism as a basis for selectivity. In: R.C. Kirkwood ed. Target sites of herbicides action.Plenum Press, New York. 1989. p. 285314.

PEREGOY, R.S.; GLENN, S. Physiological responses to fluazifop-butyl in tissue of corn (Zea mays) and soybean (Glycine max). Weed Science v. 33, p. 433446. 1981.

Página 61:

TRYEE, M.T.; PETERSON,C.A.; EDGINGTON,L.V. A simple theory regarding amtimobility of xenobiotics with special reference to the nematicide oxamyl. Plant Physiology v.63, p. 367-374. 1979.

WAIBEL, H. Global pesticide markets and future prospects for pesticides. $16^{\text {th }}$ SESSION FAO/UNEP Panel of Experts on IPM, Roma. 15p.

WOOD MACKENZIE Agrochemical Service. 1995.

Página 120:

FREITAS, R.R. Dinâmica do banco de sementes em uma comunidade de plantas daninhas com aspectos da germinação e dormência de sementes de capim marmelada (Brachiaria plantaginea (Link) Hitc.). ESAL-Lavras, 1990. 118p. (Dissertação de Mestrado) - ESAL.

Página 121:

MURRAY, B.G.; FRIESEN, L.F.; BEAULIEU, K.J.; MORRISON,I.N. A seed biossay to identify acetyl-CoA carboxylase inhibitor resistant wild oat (Avena fatua) populations. Weed Technology v.10, p. 85-89, 1996.

PEREIRA, A.R.; ARRUDA, H.V. Ajuste prático de curvas na pesquisa biológica. Fundação Cargill, Campinas. 1987. 50p.

SEBER, G.A.F.; WILD, C.J. Nonlinear regression. New York. John Wiley \& Sons eds. 1989. 
Página 122:

SPRAGUE, C.L.; STOLLER, E.W.; WAX, L.M. Common cocklebur (Xantium strumarium) resisitance to selected ALS-inhibiting herbicides. Weed Techonology v.11, p. 241-247. 1997.

STREIBIG, J.C.; GREEN, J.M. How to compare glasshouse and field dose responses. In: BCPC Monograph no. 59: Comparing glasshouse \& field pesticide performance II. p.173-180. 1994.

Página 177:

BARROS, A.C. de. Efíciência de herbicidas pós-emergentes no controle de gramineas na cultura da soja. Goiânia, 1989. 8p. (EMGOPA. Comunicado Técnico, 18).

BLANCO, H.G.; OLIVEIRA, D.A.; ARAÚJO, J.B.M.; GRASSI, N. Observações sobre o periodo em que as plantas daninhas competem com a soja (Glycine $\max ($ L.) Merril). O Biológico, v. 39, p. 31-35, 1973.

CHRISTOFFOLETI, P.J.; VICTORIA FILHO, R.; SILVA, C.B. Resistência de plantas daninhas aos herbicidas. Planta Daninha. v.12, n.1, p.13-20, 1994.

Página 178:

DURIGAN, J.C. Matocompetição e comportamento de baixas doses de herbicidas na cultura da soja (Glycine max (L.) Merril). ESALQ-Piracicaba, 1983. 163p. (Tese Doutorado) - ESALQ - Universidade de São Paulo.

Página 180:

VOLL, E.; GAZZIERO, D.L.P.; KARAM, D. Dinâmica de populações de Brachiaria plantaginea (Link) Hitchc. sob manejos de solos e de herbicidas. 1. Sobrevivência. Pesquisa Agropecuária Brasileira. v.30, n.12, p.13871396. 1995. 


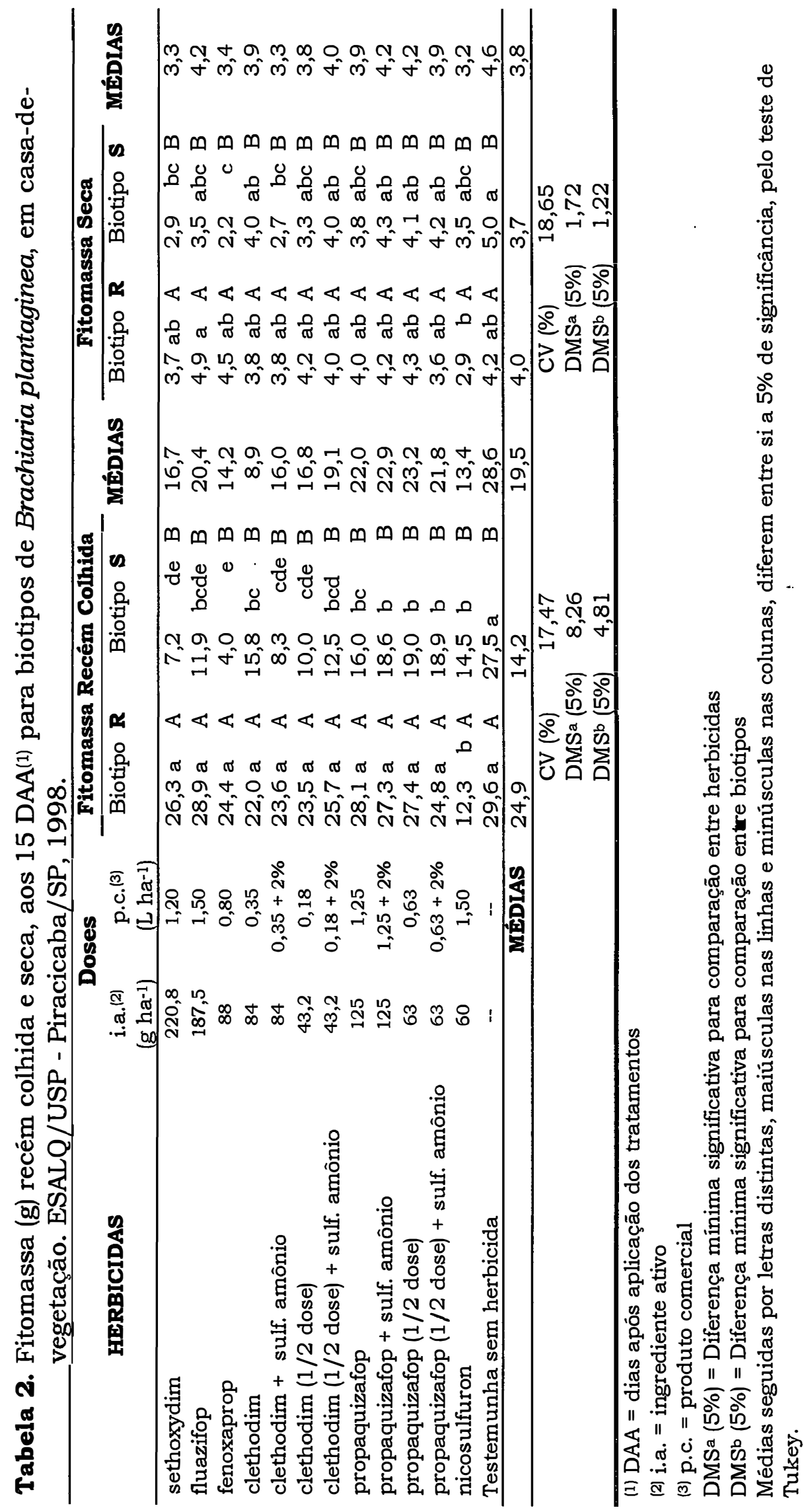




\title{
Dados Internacionais de Catalogação na Publicação (CIP) DIVISĀO DE BIBLIOTECA E DOCUMENTAÇĀO - Campus "Luiz de OueirOz"/USP
}

\author{
Cortez, Marluce Gonçalves \\ Resistência de biotipos de [Brachiaria plantaginea (Link) Hitchc.] a herbicidas
} inibidores da acetil coenzima A carboxilase / Marluce Gonçalves Cortez. - - Piracicaba, 2000.

214 p. : il.

Tese (doutorado) - Escola Superior de Agricultura Luiz de Queiroz, 2000.

Bibliografia.

1. Capim marmelada 2. Controle químico 3. Genética vegetal 4. Inibidor de enzima 5. Planta daninha 6 . População de planta 7. Resistência ao herbicida I. Título

CDD 632.58

\section{Mermitida acopia total ou parcial deste documento, desde que cituda a fonte -0 auto}

Data do depósito jun to CPQ/ESALO

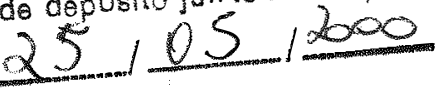


A meus pais, Genival e Maria, meus maiores motivadores, minha força e minha luz,

Aos meus irmãos Marli, Roberto e Júnior, às minhas cunhadas, cunhado e sobrinhos, vocês que sâo a minha maior torcida,

Ao meu irmão Gilberto (in memorian), a mais triste perda de minha vida.

\section{Dedico}

Ao Toni, meu marido, pelo incentivo, paciência e compreensāo, em todos os momentos.

\section{Ofereço}




\section{AGRADECIMENTOS}

A Deus, por me guiar e dar-me forças para recomeçar a cada dia.

Este trabalho foi possivel graças ao auxilio de algumas instituições e incontáveis pessoas. À todos que me ajudaram de várias maneiras e colaboraram para esta realização deixo aqui o registro de meus sinceros agradecimentos.

À Universidade Estadual de Ponta Grossa pela possibilidade de realização deste curso.

À Coordenação de Aperfeiçoamento de Pessoal de Nivel Superior (CAPES), pela concessão das bolsas de estudos no Brasil e no Exterior.

Ao Prof. Dr. Ricardo Victoria Filho pela orientação, apoio, amizade e confiança em mim depositada.

Ao Prof. Dr. Pedro Jacob Christoffoleti, autor de muitas idéias que fazem parte este trabalho, agradeço pela orientação, amizade, e por estar sempre presente e participativo comigo, e com todos seus orientados.

Ao Prof. Dr. Rafael De Prado, da Escuela Técnica Superior de Ingenieros Agrónomos y de Montes (E.T.S.I.A.M.) da Universdidad de Córdoba, Espanha, pela orientação, amizade e apoio recebidos em todos os momentos de minha permanência na Espanha.

Ao Prof. Júlio Menendez, da Universidad de Huelva, Espanha, pela orientação e auxilio imprescindiveis, e pela tarefa de treinar-me no conhecimento e utilização de técnicas avançadas de bioquímica

Ao Departamento de Quimica Agricola y Edafologia da E.T.S.I.A.M. pela calorosa acolhida, de modo especial agradeço a Ana Maria León, Maria Dolores Osuna e Jacinto Gonzales.

À ZENECA Brasil Ltda., através do colega Nestor Gabriel da Silva, pela utilização das instalaçōes da Estação Experimental em Holambra/SP, e aos colegas André e Santiago pela orientação e imprescindivel apoio na instalação de meus gigantes experimentos.

Aos funcionários do Departamento de Produção Vegetal/Esalq, de modo especial a Elizabete Sarkis São João, Silvia Borghesi, Aparecido Serrano e 
Helena Rodrigues de Camargo, sempre dispostos a ajudar e atender nossos mais urgentes pedidos. Quero agradecer em particular aos funcionários Luiz Ferrari, Aparecido Mendes e Ony Rodrigues de Campos pela presteza e dedicação com que sempre me auxiliaram.

À Prof.a. Dra. Maria Angeles Diaz Ortin e Prof. Dr. Francisco Peña Rodriguez (PyPJPS), que são professores do Departamento de Quimica Agrícola (E.T.S.I.A.M./Espanha) e, principalmente meus amigos inesqueciveis, com os quais dividi momentos de trabalho árduo, momentos muito tristes e momentos alegres também.

Meu especial agradecimento à Maria Célia Rodrigues, do Departamento de Produçāo Vegetal/Esalq, que com profissionalismo, solidariedade e amizade incomuns me auxiliou de forma árdua e intensa na fase final deste trabalho.

Aos amigos e colegas de curso que acompanharam com entusiasmo meu trabalho, meu agradecimento pela especial ajuda, pela força e pelos bons momentos compartilhados: Telma Passini, Patricia A. Monqueiro, Daniel Medeiros, Cláudio de Almeida Hehdi, Lúcia Helena Albert, Oscar José Smiderle e Remi Dambrós.

À Dra. Maria Estela Monteiro Bergamo, que com seu profissionalismo e grande sensibilidade tem me auxiliado a encontrar "um novo jeito de caminhar".

Muito obrigado a todos. Foi um privilégio trabalhar e conviver com vocês. 
SUMÁRIO

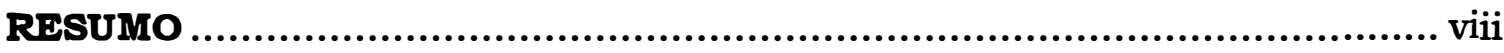

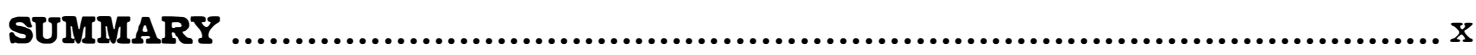

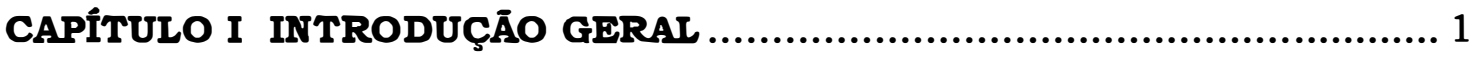

REFERÊNCIAS BIBLIOGRÁFICAS ........................................... 4

CAPÍTULO II REVISĀO DE LITERATURA...................................... 6

1 O USO DE HERBICIDAS NA AGRICULTURA ................................... 6

2 HERBICIDAS ARILOXIFENOXIPROPIONATOS E CICLOHEXANODIONAS.

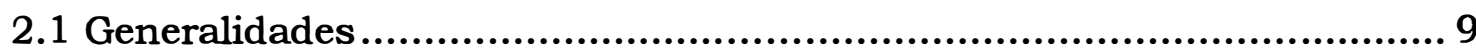

2.2 Atividade da acetil coenzima A carboxilase (ACCase) em plantas ............ 13

2.3 Modo e mecanismo de ação dos herbicidas ariloxifenoxipropiona-

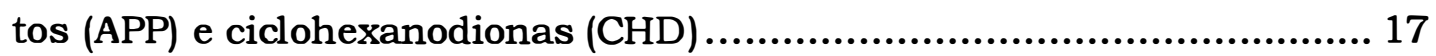

2.3.1 Inibição da sintese de ácidos graxos ............................................ 18

2.3.2 Alteração no "gradiente de prótons da membrana" ........................... 21

3 RESISTÊNCIA DE PLANTAS DANINHAS A HERBICIDAS......................... 24

3.1 Evolução e desenvolvimento da resistência......................................... 24

3.2 Resistência de plantas daninhas aos herbicidas inibidores da acetil

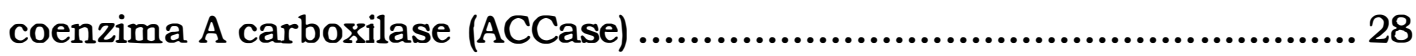

3.3 Resistência de plantas daninhas a herbicidas no Brasil ....................... 31

4 MECANISMOS DE RESISTÊNCIA DE PLANTAS A HERBICIDAS................ 33

4.1 Redução da concentração do herbicida no local de ação......................... 34

4.2 Metabolismo e destoxificação do herbicida ........................................ 36

4.3 Perda de afinidade pelo local de ação na ACCase ................................ 39

4.4 Outros mecanismos de resistência ................................................ 40

5 A PLANTA DANINHA Brachiaria plantaginea......................................... 42

REFERÊNCIAS BIBLIOGRÁFICAS ................................................ 44 
CAPÍTULO III RESISTÊNCIA CRUZADA EM BIOTIPOS DE Brachiaria plantaginea (Link) Hitchc. A HERBICIDAS INIBIDORES DA ACETIL COENZIMA A CARBOXILASE (ACCase) .......................................6 63

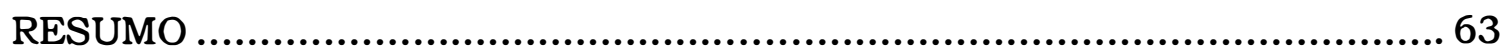

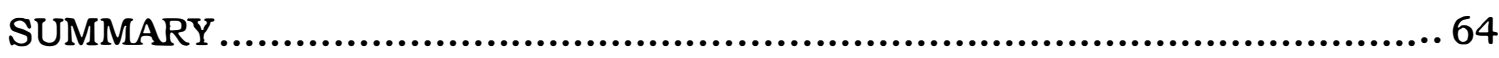

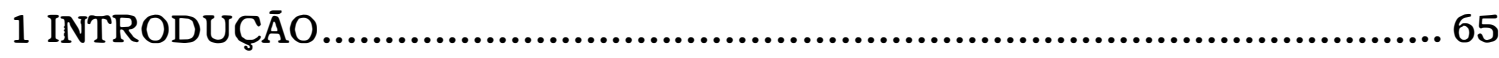

1.1 Metodologia para comprovação da resistência de plantas daninhas a herbicidas.......................................................................... 66

1.1.1 Determinação em campo .........................................................6 66

1.1.2 Determinação em laboratório .................................................. 68

1.2 Estudo da resistência através de curvas de dose-resposta..................... 70

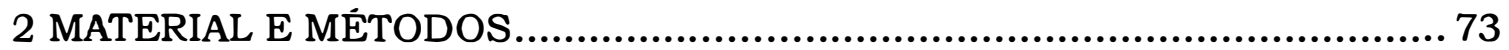

2.1 Avaliação preliminar da sensibilidade de populações de B. plantaginea suspeitas de serem resistentes a herbicidas inibidores da ACCase ........ 73

2.1.1 Seleção do material no campo..................................................... 73

2.1.2 Tratamento de sementes para quebra de dormência ....................... 75

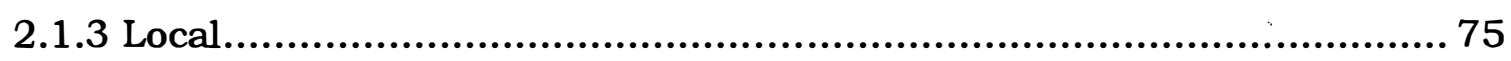

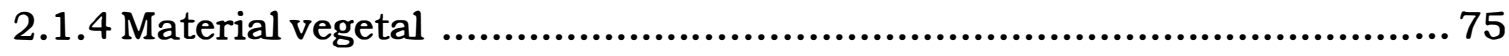

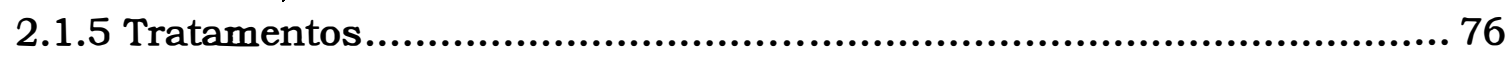

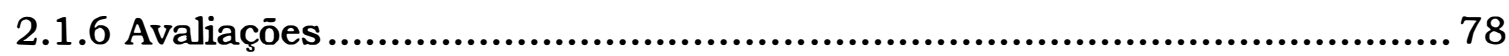

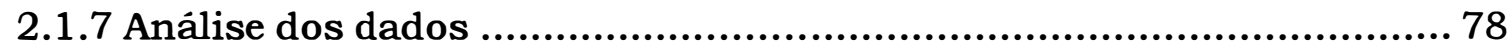

2.2 Avaliação da resistência cruzada e do grau de resistência em biotipos de $B$.

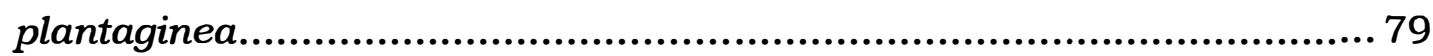

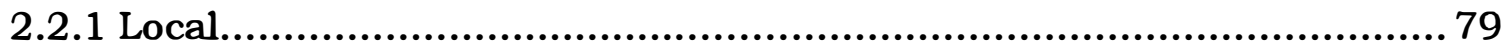

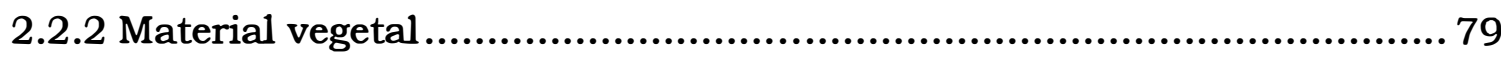

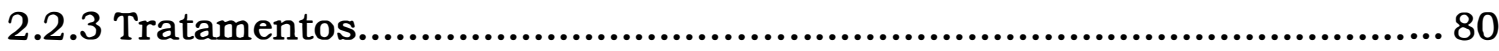

2.2.4 Avaliaçōes.......................................................................... 81

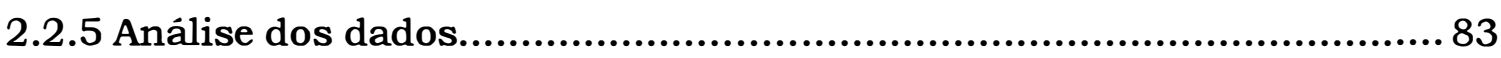

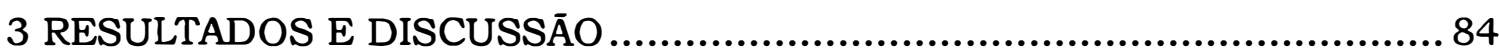

3.1 Avaliação preliminar da sensibilidade de populaçōes de Brachiaria plantaginea suspeitas de serem resistentes a herbicidas inibidores da ACCase 
3.2 Determinação da resistência cruzada e da taxa de resistência em biotipos biotipos resistentes de Brachiariaplantaginea. .94

4. CONCLUSŌES 118

REFERÊNCIAS BIBLIOGRÁFICAS 119

CAPÍTULO IV MECANISMOS DE RESISTÊNCIA A HERBICIDAS INIBIDORES DA ACETIL COENZIMA A CARBOXILASE (ACCase) EM BIOTIPOS DE Brachiaria plantaginea (Link) Hitchc.....................................123

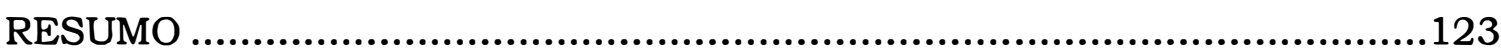

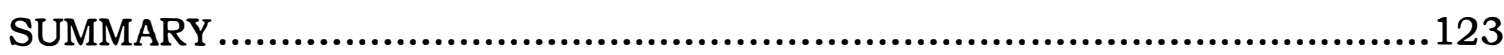

1 INTRODUÇĀO......................................................................... 124

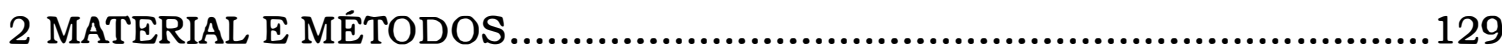

2.1 Absorção e translocação de herbicidas CHD em biotipos de B. plantaginea........................................................................129

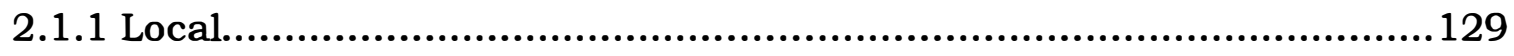

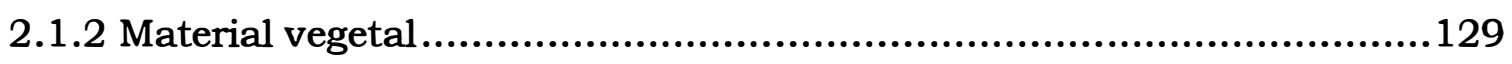

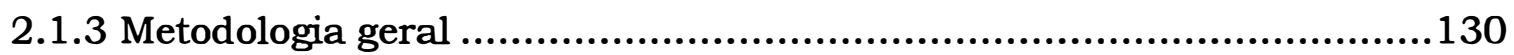

2.1.4 Tratamentos com sethoxydim .................................................132

2.1.5 Tratamentos com tepraloxydim .................................................133

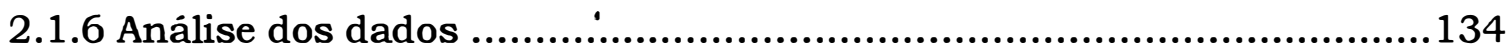

2.2 Atividade da ACCase em biotipos de B. plantaginea ...........................134

2.2.1 Extração da ACCase ................................................................... 135

2.2.2 Bioatividade enzimática para sethoxydim e tepraloxydim ..................136

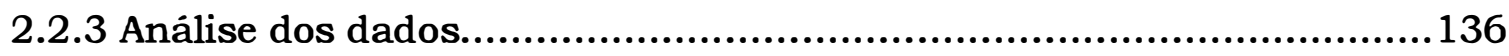

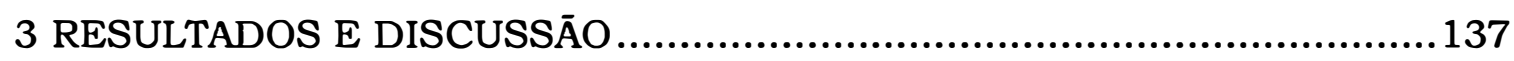

3.1 Absorção e translocação de herbicidas CHD em biotipos de Brachiaria plantaginea .............................................................................137

3.2 Atividade da ACCase em biotipos de Brachiaria plantaginea ..................144

4 CONCLUSŌES ...................................................................147

REFERÊNCIAS BIBLIOGRÁFICAS ............................................. 148 
Capítulo $v$ alternativa para O MANEJo AGRONÔMico dE Brachiaria plantaginea (Link) Hitchc. RESISTENTE A HERBICIDAS APP e CHD, EM PLANTIO DIRETO, NA CULTURA DA SOJA......................155

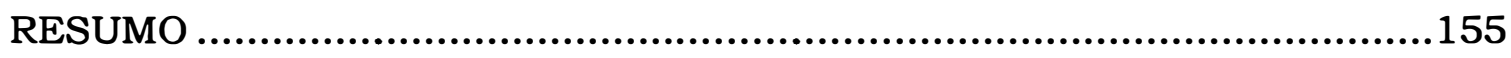

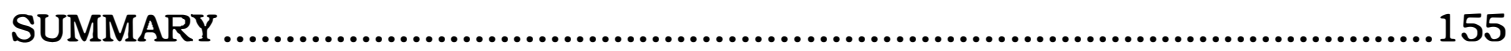

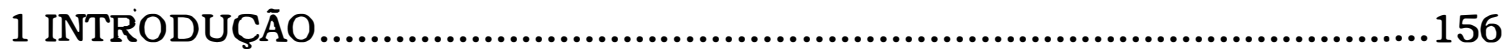

2 MATERIAL E MÉTODOS.................................................................161

2.1 Avaliação da sensibilidade de biotipos de $B$. plantaginea a herbicidas alternativos em bioensaio de casa-de-vegetação.................................161

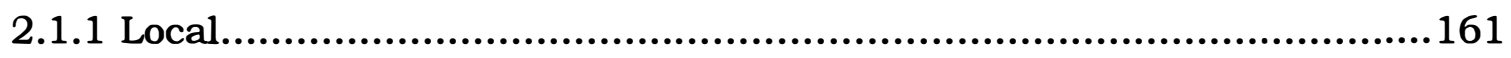

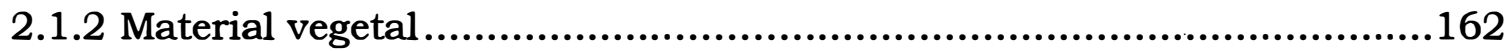

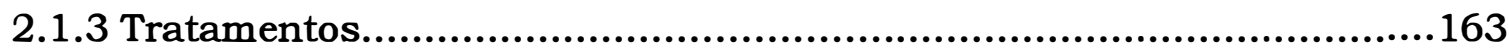

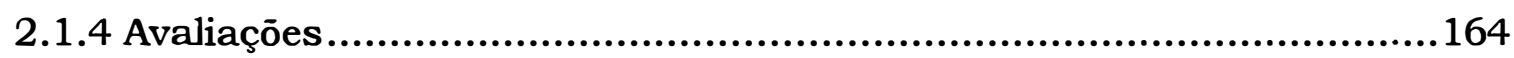

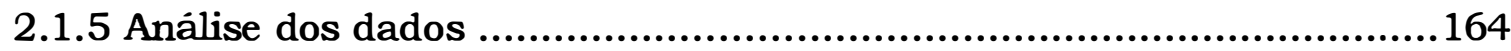

2.2 Avaliação de herbicidas alternativos no controle de população resistente de B. plantaginea em condiçōes de campo ...........................................164

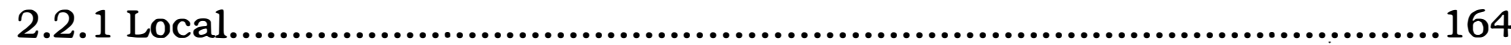

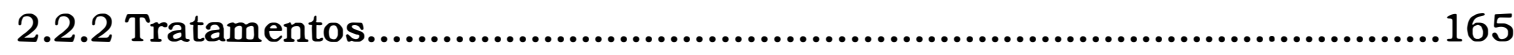

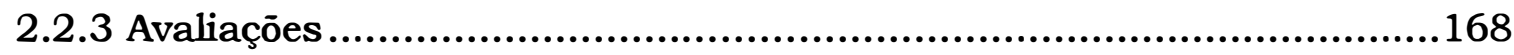

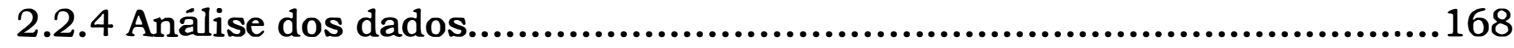

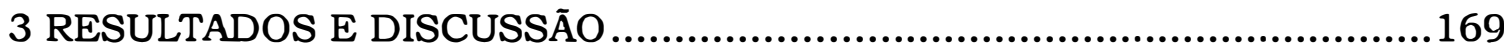

3.1 Avaliaçāo da sensibilidade de biotipos de Brachiaria plantaginea com herbicidas alternativos em bioensaio de casa-de vegetação ..........................169

3.2 Avaliação de herbicidas alternativos no controle de população resistente de Brachiaria plantaginea em condiçōes de campo ..................................... 172

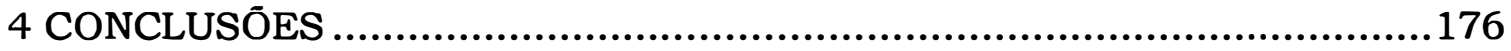

REFERÊNCIAS BIBLIOGRÁFICAS .............................................177

CAPÍTULO VI CONCLUSŌES GERAIS ..........................................181

CAPÍTULO VII REFERÊNCIAS BIBLIOGRÁFICAS ............................181 


\title{
RESISTÊNCIA DE BIOTIPOS DE Brachiaria plantaginea (Link) Hitchc. A HERBICIDAS INIBIDORES DA ACETIL COENZIMA A CARBOXILASE
}

\author{
Autora: MARLUCE GONÇALVES CORTEZ \\ Orientador: Prof. Dr. RICARDO VICTORIA FILHO \\ Co-orientador: Prof. Dr. PEDRO JACOB CHRISTOFFOLETI
}

\section{RESUMO}

A planta daninha Brachiaria plantaginea é uma das mais comuns nas áreas cultivadas com soja. $O$ controle seletivo em pós-emergência é realizado principalmente com os herbicidas inibidores da ACCase. O uso intensivo e repetido destes herbicidas em áreas cultivadas com soja no municipio de Guarapuava/PR, selecionou populaçōes desta planta daninha com menor tolerância a estes herbicidas. Esta pesquisa foi desenvolvida com o objetivo de estudar a sensibilidade destas populaçōes a herbicidas inibidores da ACCase; bem como a ocorrência de resistência cruzada em biotipos resistentes; verificar se o mecanismo de resistência é originado por alteraçōes na ACCase ou por deficiência na absorção e translocação dos herbicidas; e ainda propor alternativas de manejo para populaçōes resistentes. Através de bioensaios conduzidos em condiçōes de casa-de-vegetação, constatou-se a diferença de sensibilidade entre as populaçōes testadas, a herbicidas vários herbicidas ariloxifenoxipropionatos (APP) e ciclohexanodionas (CHD). Em bioensaios conduzidos em condiçōes de casa-de-vegetação com biotipos resistentes (R) e suscetivel (S), foram obtidas curvas de dose-resposta e $G_{50}$ que permitiram comprovar a resistência cruzada a herbicidas APP e CHD. Ensaios de laboratório permitiram comprovar que existem diferenças entre a absorção e translocação dos herbicidas testados, entre os biotipos $\mathrm{R}$ e $\mathrm{S}$, porem insuficientes para explicar os altos niveis de taxa de resistência observados. Os 
resultados obtidos em ensaios com a ACCase isolada, permitiram verificar que a ACCase extraídas de plantas $\mathrm{R}$ foram insensiveis aos herbicidas CHD testados, quando comparadas com a atividade da ACCase plantas S. Em condições de campo e em casa-de-vegetacao, foi avaliado o controle de biotipo resistente de $B$. plantaginea, a herbicida inibidores da ACCase e outros com mecanismos de ação diferentes. Comprovou-se que o herbicida nicosulfuron, embora não recomendado para a cultura da soja; e sua mistura com trifluralin, foram eficazes no controle do biotipo resistente, no campo e em casa-devegetacao. 


\title{
RESISTANCE OF Brachiaria plantaginea (Link) Hitchc. BIOTYPES TO ACETIL COENZYME A CARBOXILASE INHIBITOR HERBICIDES
}

\author{
Author: MARLUCE GONÇALVES CORTEZ \\ Adviser: Prof. Dr. RICARDO VICTORIA FILHO \\ Co-adviser: Prof. Dr. PEDRO JACOB CHRISTOFFOLETI
}

\section{SUMMARY}

The weed Brachiaria plantaginea is one of the most common infesting plant in soybean production areas of Brazil. The selective post-emergence control has been done mainly with ACCase inhibitor herbicides. The intensive and repetitive use of these herbicides in cultivated areas of soybean in Guarapuava/PR - Brazil, had selected population of this weed with lower level of susceptibility to these herbicides. This research project was developed with in order to study the sensibility of these populations to ACCase inhibitor herbicides, as well as the occurrence of cross resistance in the resistant biotypes; verify if the mechanism of resistance is the alteration on the site of the action of the herbicide in the ACCase or lack of absorption and translocation; and indicate alternatives of management of resistant populations. Through bioassay conducted under greenhouse conditions, it was detected a difference of susceptibility among the tested populations, to several ariloxyphenoxypropionates (APP) and cyclohexanodiones (CHD). GR50 values were obtained from the greenhouse experiments, comparing the resistant $(R)$ with the susceptible (S), and that allow conclusion about the cross resistance of APP and CHD herbicides. Laboratory assay proved that there are differences between the biotypes $\mathrm{R}$ and $\mathrm{S}$ with regard to absorption and translocation, however these differences are not enough to explain the level of resistance presented by the $\mathrm{R}$ biotype. Results obtained from isolated ACCase 
allowed to conclude that ACCase from R plants are insensitive to CHD and APP herbicides, when compared to ACCase from S plants. In field (resistant site) and greenhouse experiments, it was evaluated the control of $B$. plantaginea by ACCase inhibitor herbicides and by others with different mechanism of action. The herbicide nicosulfuron alone and in mixture with trifluralin were very efficient in the control of $R$ and $S$ biotype; however, nicosulfuron is not recommended for soybean weed control. 


\section{CAPÍtulO 1}

\section{INTRODUÇÃO GERAL}

A resistência das plantas daninhas aos herbicidas é um fenômeno de ocorrência em muitos países. A razão mais provável desta ocorrência é a utilização intensiva de herbicidas como principal método de controle de plantas daninhas (Le Baron \& Gressel, 1982; Powles \& Holtum, 1994; Sherman et al., 1996). Nos últimos anos diversas pesquisas tềm sido conduzidas, buscando compreender as bases fisiológicas e bioquimicas da resistência de biotipos de plantas daninhas aos herbicidas (Shimabukuro \& Hoffer, 1992; Burnet et al., 1993; Holtum et al., 1994; Maneechote et al., 1994, Marshall et al., 1994; Tardif \& Powles, 1994; Devine, 1997).

O desenvolvimento de biotipos de plantas daninhas resistentes aos herbicidas está condicionado a uma mudança da freqüência genética na populaçāo da planta daninha. A resistência ocorre com a pressāo de seleçāo, que é causada por sucessivas aplicaçōes de herbicida na dose recomendada. Assim, a tolerância de plantas daninhas aos herbicidas é diferenciada da resistência pois a tolerância é uma caracteristica inerente da planta, antes mesmo da primeira aplicaçāo do herbicida naquela área. Já, a resistência de plantas daninhas aos herbicidas é umá caracteristica expressa por biotipos de plantas daninhas dentro de uma populaçāo. Ela ocorre por causa da pressāo de seleçāo que é causada por aplicaçōes sucessivas de um mesmo herbicida.

A utilizaçāo de herbicidas na agricultura, portanto, deve estar condicionada a recomendaçōes práticas para evitar o desenvolvimento de 
biotipos de plantas daninhas resistentes. Estes biotipos podem restringir ou inviabilizar o uso futuro dos herbicidas aplicados, pois a eficácia de controle fica reduzida a niveis abaixo dos aceitáveis pelo agricultor. Desta maneira, é necessário que a resistência de plantas daninhas aos herbicidas seja compreendida de maneira aprofundada pelas pessoas envolvidas direta ou indiretamente envolvidas com o manejo das plantas daninhas, visando a adoçāo de medidas adequadas e racionais que evitem ou retardem o aparecimento de biotipos de plantas daninhas resistentes.

A resistência de plantas daninhas a herbicidas tem sido constatada em algumas regiōes de soja do Brasil localizadas nos Estados do Mato Grosso do Sul, Rio Grande do Sul e Paraná. No entanto, entre as pesquisas desenvolvidas sobre este fenōmeno no Brasil, sāo poucos os trabalhos relacionados com as causas fisiológicas e/ou bioquimicas do desenvolvimento de biotipos resistentes de plantas daninhas.

A cultura de soja ocupa expressivas áreas do Estado do Paraná, com alta produtividade e tem como principal sistema de produçāo o plantio direto. Dentre os principais fatores de perdas na produtividade da cultura da soja destaca-se a competiçāo das plantas daninhas, principalmente o capimmarmnelada ou papuā [Brachiaria plantaginea (Link) Hitchc.] O controle desta planta na cultura da soja é realizado principalmente por meio de herbicidas do tipo graminicidas, em condiçōes de pós-emergência. Esses herbicidas pertencem aos grupos quimicos ariloxifenoxipropionatos (APP) e ciclohexanodionas (CHD), cujo mecanismo de açāo é a inibiçāo da atividade da acetil coenzima A carboxilase (ACCase).

Recentemente, tem-se observado falhas no controle quimico desta planta daninha em diversos campos de produçāo de soja, onde os herbicidas APP e CHD vinham sendo utilizados de forma repetitiva, há vários anos. Todas as populações escapes de B. plantaginea encontram-se associadas a um histórico de cultivo sucessivo de soja no verāo, e pulverizaçāo anual de herbicidas inibidores da ACCase no controle em pós-emergência de gramineas. Desta forma, atribui-se como causa destas falhas de controle a ocorrência de biotipos de $B$. plantaginea resistentes aos herbicidas inibidores da ACCase. 
Além de avaliar a resistência de biotipos de Brachiaria plantaginea aos herbicidas inibidores da ACCase, foram realizados ensaios com os seguintes objetivos:

- Comprovar a hipótese de ocorrência de diferentes populaçōes de $B$. plantaginea resistentes a herbicidas inibidores da ACCase seletivos à soja, utilizados em plantio-direto;

- Estudar a resposta de biotipos resistentes de B. plantaginea aos herbicidas inibidores da ACCase (ariloxifenoxipropionatos e ciclohexanodionas), registrados no Brasil para a cultura da soja;

- Estudar as diferenças na tolerāncia destes biotipos a estes produtos e a hipótese do mecanismo de resistência ser originado por alteraçōes na sensibilidade da ACCase ou pela deficiēncia na absorção e translocação dos herbicidas nas plantas;

- Propor alternativas de manejo de populaçōes resistentes, visando reduzir ou evitar a ocorrência deste fenômeno. 


\section{REFERÊNCIAS BIBLIOGRÁFICAS}

BURNET, M.W.; LOVEYS, B.R.; HOLTUM, J.A.M.; POWLES, S.B. Increased detoxification is a mechanism of simazine resistance in Lolium rigidum. Pesticide Biochemistry and Physiology, n. 46, p. 207-218, 1993.

DEVINE, M.D. Target-site based resistance to ACCase inhibitors. In: Weed and Crop Resistance to Herbicides (DE PRADO, R.; JORRIN, J.; GARCIATORRES, L., eds). Kluwer Academic Publisher. 1997.

HOLTUM, J.A.M.; HÄUSLER, R.E.; DEVINE, M.D.; POWLES, S.B. Recovery of transmembrane potentials in plants resistant to aryloxyphenoxypropanoate herbicides: A phenomenon awaiting explantion. Weed Science, n.42, p.293-301, 1994.

LeBARON, H.M.; GRESSEL, J. Herbicide resistance in plants. New York: John Wiley \& Sons. 1982. 441p.

MANEECHOTE, C.; HOLTUM, J.A.M.; PRESTON, C.; POWLES, S.B. Resitant acetyl-CoA carboxylase is a mechanism of herbicide resistance in a biotype of Avena sterilis ssp. Ludoviciana. Plant Cell Physiology, v. 35, n.4, p.627-635, 1994.

MARSHALL G.; KIRKWOOD, R.C.; LEACH, G.E. Comparative studies on graminicide-resistant and susceptible biotypes of Eleusine indica. Weed Research, v. 34, n.3, p.177-185, 1994.

POWLES, S.B; HOLTUM, J.A.M. Herbicide resistance in plants: Biology and biochemistry. Boca Raton: Lewis, 1994, 353 p. 
SHERMAN, T.D.; VAUGHN, K.C.; DUKE, S.O. Mechanism of action and resistance to herbicides. In: DUKE, S.O. (Ed.) Herbicides Resistant Crops. Boca Raton: CRC press, 1996. p.14-28.

SHIMABUKURO, R.H. ; HOFFER, B.L.. Effect of Diclofop on the Membrane Potentials of Herbicide-Resistent and Susceptible Annual Ryegrass Root Tips. Plant Physiology, v.98, p.1415-1422, 1992.

TARDIF, F.J.; POWLES, S.B. Herbicide multiple-resistance in a Lolium rigidum biotype is endowed by multiple mechanisms: isolation of a subset with resistant acetyl-CoA carboxylase. Physiologia Plantarum, v.91, p.488494, 1994. 


\section{CAPÍTULO II}

\section{REVISĀO DE LITERATURA}

\section{O USO DE HERBICIDAS NA AGRICULTURA}

O desenvolvimento pelo qual a agricultura tem passado nas últimas décadas, com aumento das áreas cultivadas utilizando culturas geneticamente melhoradas e com alta produtividade, e a aplicaçāo de tecnologias de produçāo cada vez mais avançadas, tem permitido que a produçāo agricola mundial apresente uma taxa de crescimento acima do crescimento global da populaçāo humana, prevendo-se que esta tendência se mantenha pelos próximos anos (FAO, 1997). A garantia e a proteçāo destas altas produçōes requerem cuidadoso manejo dos agroecossistemas e adoçāo de novas tecnologias, fatores estes, diretamente relacionados com o uso de agroquimicos. A agricultura mundial, tem feito uso intensivo de insumos, dentre os quais, o consumo de produtos quimicos, avaliado em 26 bilhōes de U\$ dólares por ano, sendo $46 \%$ destes em herbicidas.

Desde a sua adoçāo nos sistemas de produçāo agricola modernos, os herbicidas tornaram-se a principal ferramenta dos programas de controle de plantas daninhas. Coble (1996) e Menendez \& De Prado (1998) apontam as seguintes razōes do uso intensivo de herbicidas, nos atuais sistemas agricolas:

a) São produtos que oferecem controle de amplo espectro de plantas daninhas com eficácia superior a outras técnicas de controle, em muitas situaçōes; 
b) Sāo de fácil aplicaçāo pois nāo requerem equipamentos sofisticados ou práticas culturais específicas, antes ou após a sua aplicaçāo;

c) Apresentam uma relaçāo custo/benefício favorável, quando comparado a outras técnicas de controle;

d) São agronomicamente versáteis, permitindo ao agricultor escolher quando e como controlar o problema de plantas daninhas.

O mercado mundial de consumo de agroquímicos nāo é uniforme nos diversos sistemas de produçāo, pois existe uma relaçāo direta entre o grau de desenvolvimento tecnológico dos sistemas agrícolas e o nivel dos insumos utilizados (Neale \& Sutton, 1993). Fatores como: saturaçāo nos mercados, desaceleraçāo nas economias de países desenvolvidos, unidos à crescente rejeiçāo que o controle químico de pragas, doenças e plantas daninhas tem encontrado junto aos consumidores, têm reduzido a demanda e venda de agroquímicos durante a última década (Zados, 1992; Waibel, 1994). No entanto no Brasil o consumo vem aumentando nos últimos anos, conforme dados do Sindag. 1999.

A importância dos herbicidas na agricultura apoia-se em valores: suas vendas em 1994 alcançaram aproximadamente 13 bilhōes de U\$ dólares (Wood Mackenzie, 1995), constituindo quase 50\% do valor total de agroquimicos consumidos mundialmente. Os Estados Unidos da América do Norte constituem o maior consumidor mundial de herbicidas, e a América Latina se situa em quarto lugar neste mercado consumidor. Nas culturas, os cereais utilizam $45 \%$ do total de herbicidas consumidos no mundo, sendo a cultura da soja a segunda maior consumidora mundial destes produtos.

Com relaçāo ao Brasil, a situaçāo das vendas de agroquímicos superaram, em 1998, os 2.400 milhōes de U\$ dólares, dos quais $55,8 \%$ foram herbicidas (Tabela 1). A cultura de soja foi a principal consumidora de herbicidas, acumulando mais de $50 \%$ das vendas destes produtos (Tabela 2). 
A cultura de soja tem mantido, na última década, a média de consumo em torno de $50 \%$ do total de agroquimicos comercializados no Brasil.

Tabela 1. Indicadores do consumo por classe de agroquímicos, no mercado brasileiro, em 1998 (Sindag, 1999).

\begin{tabular}{|c|c|c|c|c|c|c|}
\hline \multirow{2}{*}{$\begin{array}{l}\text { Categoria de } \\
\text { Agroquimico }\end{array}$} & \multicolumn{3}{|c|}{ QUANTIDADE } & \multirow{2}{*}{\multicolumn{2}{|c|}{$\begin{array}{c}\text { Valor } \\
\text { Milhōes } \\
\text { US\$ }\end{array}$}} & \multirow[b]{2}{*}{$\%$} \\
\hline & $\begin{array}{c}\text { Produto } \\
\text { Comercial (t) }\end{array}$ & $\%$ & $\begin{array}{l}\text { Ingrediente } \\
\text { ativo (t) }\end{array}$ & & & \\
\hline Herbicidas & 161.096 & 51,1 & 69.177 & 57,1 & 1.369 & 55,8 \\
\hline Inseticidas & 79.398 & 26,9 & 20.390 & 16,8 & 582 & 23,7 \\
\hline Fungicidas & 47.164 & 15,9 & 19.993 & 16,5 & 436 & 17,8 \\
\hline Outros & 17.875 & 6,1 & 11.540 & 9,6 & 66 & 2,7 \\
\hline TOTAL & 295.533 & 100 & 121.100 & 100 & 2.452 & 100 \\
\hline
\end{tabular}

Tabela 2. Indicadores do consumo de herbicidas por cultura no Brasil, em 1998 (Sindag, 1999).

\begin{tabular}{|c|c|c|c|c|c|c|}
\hline \multirow{3}{*}{ CULTURAS } & \multicolumn{4}{|c|}{ Quantidade (t) } & \multirow{2}{*}{\multicolumn{2}{|c|}{$\begin{array}{l}\text { Valor em } \\
\text { bilhōes }\end{array}$}} \\
\hline & \multirow{2}{*}{$\begin{array}{c}\text { Produto } \\
\text { Comercial (t) }\end{array}$} & \multicolumn{3}{|c|}{ Ingrediente } & & \\
\hline & & $\%$ & Ativo (t) & $\%$ & de US\$ & $\%$ \\
\hline Soja & 63.481 & 39,4 & 27.887 & 40,3 & 728 & 53,2 \\
\hline Cana-de-açúcar & 18.951 & 11,8 & 9.138 & 13,2 & 173 & 12,7 \\
\hline Milho & 27.460 & 17,0 & 13.487 & 19,5 & 146 & 10,7 \\
\hline Arroz sequeiro+irrigado & 8.793 & 5,5 & 4.296 & 6,2 & 80 & 5,8 \\
\hline Café & 7.838 & 5,0 & 3.799 & 5,5 & 43 & 3,2 \\
\hline Algodão & 3.639 & 2,1 & 1.663 & 2,4 & 33 & 2,4 \\
\hline Citros & 4.030 & 2,5 & 1.936 & 2,8 & 22 & 1,6 \\
\hline Feijão & 3.662 & 2,3 & 1.360 & 2,0 & 41 & 3,0 \\
\hline Trigo & 2.646 & 1,6 & 1.336 & 2,0 & 19 & 1,4 \\
\hline Fruticultura & 948 & 0,6 & 402 & 0,6 & 6 & 0,4 \\
\hline Hortaliças & 795 & 0,5 & 236 & 0,3 & 7 & 0,5 \\
\hline Outros & 18.853 & 11,7 & 3.637 & 5,3 & 71 & 5,2 \\
\hline Total & 161.096 & 100 & 69.177 & 100 & 1.369 & 100 \\
\hline
\end{tabular}




\section{HERBICIDAS ARILOXIFENOXIPROPIONATOS E CICLOHEXANODIONAS}

\subsection{Generalidades}

Os ariloxifenoxipropionatos e ciclohexanodionas são dois grupos químicos de herbicidas utilizados para o controle de gramineas (nome popular dado às plantas pertencentes à família Poaceae) perenes e anuais, em condiçōes de pós-emergência. Esses herbicidas são geralmente recomendados para culturas pertencentes à classe das dicotiledôneas. Os nomes ariloxifenoxipropionatos e ciclohexanodionas são comumente abreviados na literatura como APP e CHD, respectivamente (Powles \& Holtum, 1994).

Os APP e CHD, apresentam como mecanismo de ação a inibição da sintese de ácidos graxos (Burton et al., 1989). Os herbicidas tiorcarbamatos e cloroacetamidas também inibem o processo metabólico da sintese de ácidos graxos, embora ainda exista certa controvérsia entre o pesquisadores da Ciência das Plantas Daninhas a respeito deste mecanismo de ação.

Esses dois grupos apresentam algumas diferenças na estrutura química, porém possuem aspectos semelhantes na atividade em plantas, nos niveis físiológico e bioquímico, indicando que existem elementos estruturais comuns responsáveis pela atividade biológica sobre as plantas daninhas e pelo espectro de seletividade para as culturas (Tabela 3).

Os herbicidas APP foram desenvolvidos no final dos anos 70 , e os herbicidas CHD alguns anos mais tarde. Desde então, tem crescido a utilização destes herbicidas no controle de plantas daninhas do tipo gramineas, em diversas culturas. Mais recentemente, outros herbicidas APP e CHD têm sido desenvolvidas no mercado mundial e brasileiro, permitindo aos produtores a utilização destes compostos diversas culturas. 
Tabela 3. Herbicidas APP e CHD registrados no Brasil, até 1998, para controle de plantas daninhas (Rodrigues \& Almeida, 1998).

\begin{tabular}{|c|c|c|c|}
\hline Grupo Quimico & $\begin{array}{l}\text { Nome } \\
\text { comum }\end{array}$ & $\begin{array}{c}\text { Principais culturas } \\
\text { registradas }\end{array}$ & $\begin{array}{c}\text { Nome } \\
\text { Comercial }\end{array}$ \\
\hline \multirow[t]{7}{*}{ Ariloxifenoxipropionatos (APP) } & diclofop-methyl & Soja, batata, feijão, trigo & Iloxan \\
\hline & fenoxaprop-ethyl & Soja, arroz, fumo & Furore \\
\hline & fenoxaprop-p-ethyl & Soja, batata, feijão & Podium \\
\hline & fluazifop-p-butil & $\begin{array}{l}\text { Soja, algodão, café, } \\
\text { eucalipto, citros }\end{array}$ & Fusilade \\
\hline & haloxyfop-methyl & Soja, eucalipto, pinho & Gallant \\
\hline & propaquizafop & Soja, algodão & Shogum \\
\hline & quizalofop-ethyl & Soja, algodão, feijão & Targa \\
\hline \multirow[t]{3}{*}{ Cichlohexanodionas (CHD) } & butroxydim & $\begin{array}{l}\text { Soja, feijão, algodão, } \\
\text { girassol, batata }\end{array}$ & Falcon \\
\hline & clethodim & $\begin{array}{l}\text { Soja, feijão, algodão, } \\
\text { tomate }\end{array}$ & Select \\
\hline & sethoxydim & $\begin{array}{l}\text { Soja, algodão, feijão, } \\
\text { eucalipto, girassol }\end{array}$ & Poast \\
\hline
\end{tabular}

A variabilidade na estrutura quimica dos APP e CHD permite o desenvolvimento de diversos herbicidas com diferentes atividades biologicas e de seletividade. Alguns exemplos estão representados na Figura 1. Estes herbicidas são geralmente aplicados em pós-emergência e, para facilitar sua absorção por meio da cutícula foliar, são comumente formulados como ésteres de seus correspondentes ácidos. Ainda que estes ésteres apresentem alguma atividade fitotóxica, são considerados como precursores dos herbicidas. Uma vez dentro do tecido vegetal, são rapidamente ativados à sua forma ácida por hidrólises, mediante esterases (Shimabukuro et al., 1979). Quando ativados, os APP são translocados para as regiōes meristemáticas, onde exercem ação herbicídica (Brezeanu et al., 1976; Duke \& Kenyon, 1988; Hoppe, 1989). 


\section{Âcidos ariloxifenoxapropiônicos}<smiles>CC(Oc1ccccc1)C(=O)O</smiles>

Diclofop-methyl<smiles>CCOC(=O)C(C)Oc1ccc(Oc2cnc3cc(Cl)ccc3n2)cc1</smiles>

Quizalofop-p-ethyl<smiles>CC(Oc1ccc(Oc2ccc(C(F)(F)F)cn2)cc1)C(=O)O</smiles>

Fluazifop-p-butil<smiles>CC(Oc1ccc(Oc2ncc(C(F)(F)F)cc2Cl)cc1)C(=O)O</smiles>

Haloxyfop

\section{Ciclohexanodionas}<smiles>CCC(=NOCc1ccc(Cl)cc1)C1=C(O)CC(C2CCOCC2)CC1=O</smiles>

Tepraloxydim<smiles>CCCCCCC(C)SC(C)CC1CC(=O)C(C(CC)=NO)=C(O)C1</smiles>

Clethodim<smiles>CCCCC(=NOCC)C1=C(O)CC(CC(C)SCCC)CC1=O</smiles>

Sethoxydim

Figura 3. Estruturas quimicas de alguns herbicidas inibidores da ACCase. 
Ainda que se saiba que a ACCase de dicotiledôneas é insensivel a estes herbicidas, e que a de gramineas é normalmente muito sensivel (Walker et al., 1988; Burton et al.; 1989), as diferentes espécies de plantas desta familia apresentam ACCases com distintas sensibilidades. Por exemplo, a ACCase de milho é muito mais sensivel que a de trigo ou de cevada.

A eficácia no controle das espécies de plantas daninhas gramineas é diferenciada entre os herbicidas APP e CHD. Como exemplo, o fluazifop-p-butil é mais eficaz no controle de Sorghum halepense que outros herbicidas. Por isso, as doses a serem utilizadas para diferentes espécies de plantas daninhas também podem ser diferentes, revelando que distintas espécies apresentam suscetibilidade variável a um herbicida (Devine \& Shimabukuro, 1990; Garcia Torres \& Fernández-Quintanilla, 1991; Rodrigues \& Almeida, 1998).

As doses dos herbicidas APP e CHD, recomendadas para o controle de plantas daninhas nas culturas, são relativamente baixas quando comparadas com a maioria dos demais herbicidas, como é o caso do clethodim, haloxyfop, propaquizafop e quizalofop (Rodrigues \& Almeida, 1998). Seu uso não é recomendado em misturas com herbicidas hormonais por apresentar efeitos antagônicos (Olson \& Nalewaja, 1981; Kafiz et al., 1989; O’Sullivan, 1990; Shimabukuro, 1990).

Os herbicidas CHD não possuem a forma éster, nem sofrem hidrólises na planta. São moléculas ativas e capazes de se translocar até os meristemas, onde exercem sua ação herbicidica, semelhante aos APP. Os grupos APP e CHD são formados por herbicidas sem atividade no solo, sua adsorção é reduzida e apresentam uma elevada lisiviação, embora sejam bastante insolúveis em água (WSSA, 1989; Garcia Torres \& FernándezQuintanilla, 1991; Rodrigues \& Almeida, 1998). 


\subsection{Atividade da acetil coenzima A carboxilase (ACCase) em plantas}

A acetil coenzima A carboxilase (ACCase, EC 6.4.1.2) é uma coenzima constituinte de uma proteina biotinada que catalisa a reaçāo de carboxilaçāo do acetil-CoA para formar malonil-CoA, utilizando ATP. O malonil-CoA se forma nos plastídeos e no citosol, porém nāo é utilizado para a mesma funçāo em ambos comparimentos (Devine \& Shimabukuro, 1994). Nas plantas, o malonil CoA participa em várias reaçōes e rotas, dentre as quais se destacam a biossintese e elongaçāo de ácidos graxos (Harwood, 1988); a sintese de alguns metabólitos secundários, como os flavonóides (Nicolau \& Hawke, 1984) e a transferência do grupo malonil a aminoácidos e glicosideos.

A ACCase catalisa duas reaçōes parciais: primeiro, a biotina é carboxilada em uma reaçāo que requer ATP e bicarbonato, neste intervalo, o grupo $\mathrm{CO}_{2}$ ativado é entāo transferido a acetil CoA (carboxitransferase) para formar malonil-CoA. A reaçāo catalisada pela ACCase foi citada por PostBeittenmiller et al. (1991) como uma importante etapa da biossintese de lipideos e transcorre em dois passos:

a) Enzima-biotina $+\mathrm{HCO}_{\overline{3}}+\mathrm{ATP} \rightarrow$ Enzima-biotina- $\mathrm{CO}_{2}+\mathrm{ADP}+\mathrm{Pi}$

b) Enzima-biotina $+\mathrm{CO}_{2}+$ Acetil CoA $\rightarrow$ Enzima-biotina + Malonil-CoA

A Figura 2 representa a rota metabólica da sintese de ácidos graxos em plantas superiores. A ACCase presente nas plantas foi amplamente estudada em gramineas, por ser o local de açāo dos herbicidas APP e CHD. Os herbicidas destes grupos químicos sāo inibidores especificos da ACCase em algumas gramineas, porém nāo possuem efeito em outras familias de monocotiledôneas e de dicotiledôneas. 


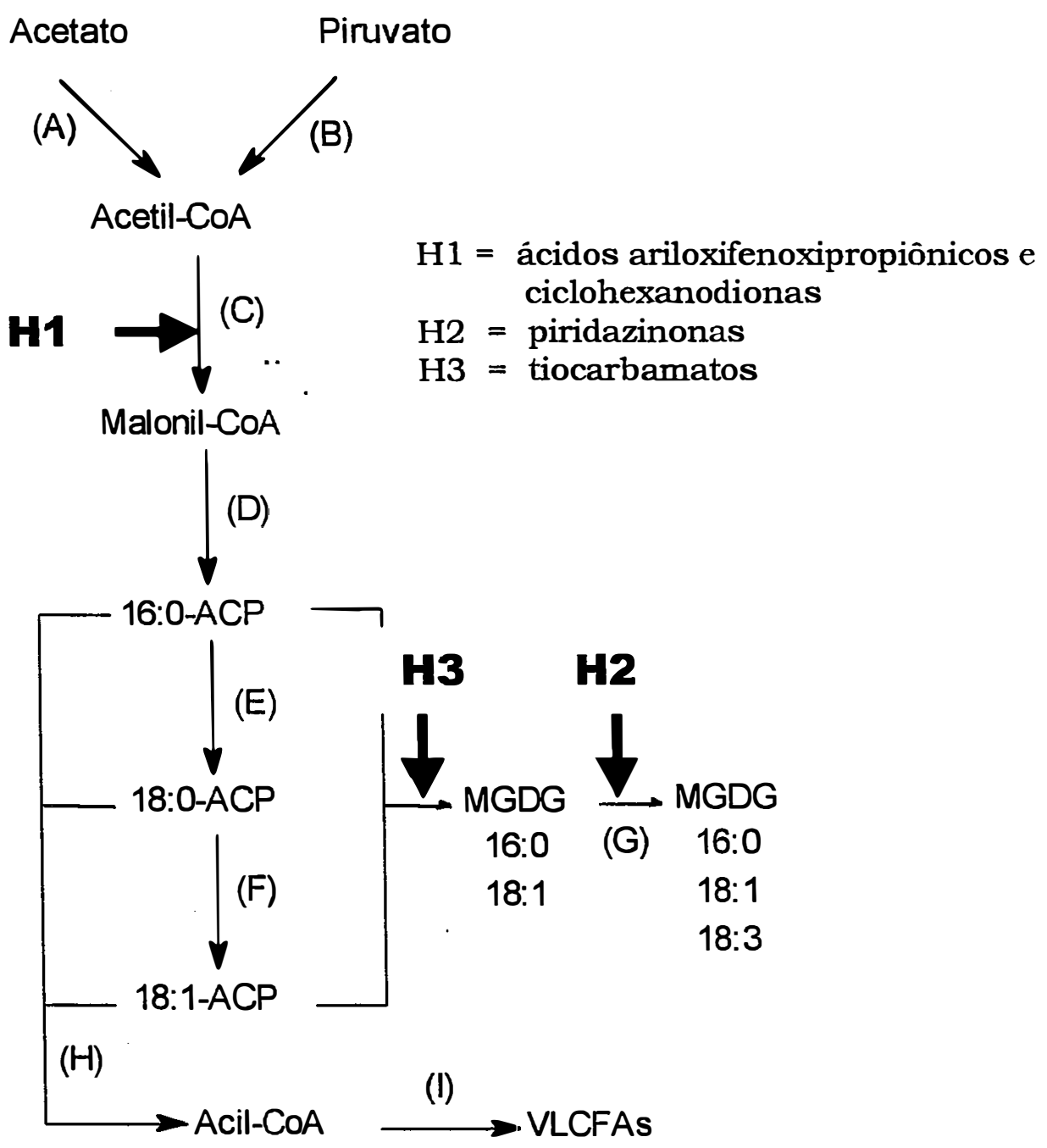

Figura 2. Principais rotas da sintese de ácidos graxos saturados, insaturados e de cadeia longa em plantas. H1, H2 e H3 são sítios de inibição pelos herbicidas. As enzimas que catalisam as reaçōes são: (A) acetato tioquinase, (B) piruvato desidrogenase, (C) acetil-CoA carboxilase, (D) complexo ácido graxo sintetase tipo II, (E) palmitol-ACP elongase, (F) e (G) diferentes saturases, $(\mathrm{H})$ um sistema de transferência de acil-CoA (plastídios $\rightarrow$ citoplasma), (I) complexo acil-CoA sintetase tipo III e elongases especificas. $\mathrm{ACP}=$ proteina transportadora do grupo acil; MGDC = monogalactosildiacilglicérido; VLCFAs = lioproteinas ácidos graxos de cadeia longa (> C-18). Os números significam quantidades de carbonos e números de ligações não saturadas, por exemplo: 18:1 = 18 carbonos e 1 ligação dupla. (Adaptado de Gronwald, 1991 e Devine et al., 1993). 
Um estudo de separação e caracterização das diferentes isoformas de ACCase de dicotiledôneas foi realizado com ervilha e mostrou que nesta espécie existem duas formas de ACCase muito diferentes: uma multimérica, denominada procariota, por causa da sua semelhança com a isoforma dos microrganismos, e outra multifuncional, denominada eucariota, similar à descrita em gramineas (Alban et al., 1994; Konishi \& Sasali, 1994). A forma procariota se localiza nos plastídeos, tem peso molecular de $700 \mathrm{kDA}$ e está composta de pelo menos três subunidades diferentes (das quais somente uma é biotinada), com massas moleculares de 332 a $79 \mathrm{kDa}$ (Alban et al., 1994). A eucariota se encontra no citosol e possui massa molecular de $220 \mathrm{kDa}$.

Todas as dicotiledôneas estudadas apresentam a forma procariota nos plastídeos, a forma eucariota no citosol. Nas gramineas, não existe a forma procariota e existem várias isoenzimas da forma eucariota tanto em plastideos como no citosol (Sasaki et al., 1995).

$\mathrm{O}$ fato de as gramineas possuírem a forma eucariota e não a forma procariota da ACCase em seus plastídeos é uma possivel explicação da diferente tolerância destas plantas aos herbicidas APP e CHD. Estudos recentes sobre as diferenças entre as ACCases de trigo e de ervilha indicam que a forma procariota é tolerante aos graminicidas, porém a forma eucariota é sensivel a eles (Sasaki et al., 1993; Konish \& Sasaki, 1994).

$\mathrm{O}$ primeiro estudo de separação da atividade da ACCase revelou que existiam isoenzimas diferentes em folhas de milho, que denominaram ACCase I e ACCase II, com massas moleculares de 227 e $219 \mathrm{kDa}$, respectivamente (Egli et al., 1993). A forma ACCase I, encontrada em maior proporção no tecido foliar (85\%) foi localizada em cloroplastos do mesófilo da folha, enquanto que a forma ACCase II (15\% da atividade ACCase total) se localizava em outros compartimentos, possivelmente no citosol. Vários autores citam que esse fato deve estar associado a processos diferentes, relacionados com a necessidade de malonil-CoA fora dos plastídeos. Das formas purificadas, somente a ACCase I (cloroplástica) mostrou-se altamente suscetivel aos herbicidas APP e CHD. 
Enquanto o papel da ACCase cloroplástica está estreitamente associado à sintese de lipídeos, a citoplasmática está relacionada com a necessidade de malonil-CoA no citoplasma. Entretanto, existem ainda muitas especulaçōes sobre a forma extraplastídica, não se conhecendo a razão da existência de formas enzimáticas diferentes no citoplasma e no plastídeo de dicotiledôneas, sua origem e suas diferenças como catalizadores enzimáticos (Gronwald, 1991).

As dicotiledôneas e monocotiledôneas não gramineas são tolerantes aos APP e CHD. O recente estudo da enzima acetil-CoA carboxilase cloroplástica de ervilha mostrou que esta enzima é altamente insensivel aos graminicidas, o que sugere que as dicotiledôneas são tolerantes devido a presença de uma forma diferente de ACCase nos plastídeos (Alban et al., 1994). A forma multifuncional cloroplástica das gramineas è geralmente, muito suscetivel aos graminicidas. Algumas formas de gramineas como Festuca rubra e Poa annua apresentam uma forma tolerante de ACCase ou parcialmente tolerante a alguns herbicidas APP e/ou CHD (Secor et al., 1989; Herbert et al., 1996), o que justifica seu comportamento em condiçōes de campo, frente a estes herbicidas.

A compartimentalização destas formas de ACCase sugere que elas devem apresentar funçōes diferentes e que, portanto, ambas são necessárias à planta. Em leveduras e animais, a forma eucariota, no citosol, elabora o malonil-CoA necessário para a sintese de ácidos graxos (Wakil et al., 1993). No entanto, em plantas onde a sintese de ácidos graxos ocorre principalmente nos plastídeos, a ACCase é encarregada de formar malonil-CoA para reiniciar a sintese de ácidos graxos de novo. Como não existe nenhuma evidência de que esta sintese ocorra fora dos plastídeos nas plantas, parece que o papel principal da forma citosólica nas plantas é a produção de malonil-CoA, necessário para elongação de ácidos graxos de cadeia longa e para a sintese de flavonóides. 


\subsection{Modo e mecanismo de ação dos herbicidas ariloxifenoxipropionatos (APP) e ciclohexanodionas (CHD)}

Os herbicidas, na sua maioria, são tóxicos às plantas por causa de sua atuação sobre um sítio primário de ação, de especial relevância biológica. Este sítio primário é o lugar onde o herbicida atua ou interfere de alguma maneira, ocasionando por fim, a morte da planta. É possivel estudar a ação do herbicida em duas fases: na primeira fase, considerando o movimento do herbicida até o sítio de ação (modo), e na segunda fase, levando em conta as conseqüências metabólicas que resultam da interação com este sitio (mecanismo). A primeira fase começa com a aplicação do herbicida na planta, por via foliar ou por radicular. Ao entrar na planta e antes de chegar ao seu sitio de ação, o herbicida segue uma série de passos que inclui a entrada nas células, a sua difusão em curtas distāncias, o transporte a longa distāncia, a conversão metabólica do herbicida e a entrada em organelas celulares. A interação do herbicida com o sitio de ação pode ser considerada como o primeiro passo da segunda fase, sendo seguida por uma série de reaçōes tóxicas que resultam na morte da planta.

Ambos grupos quimicos caracterizam-se por produzir sintomas similares nas espécies de plantas suscetiveis. Os sintomas de fitotoxicidade são evidenciados nas regiōes meristemáticas, onde a sintese de lipideos para a formação de membranas celulares é intensa. Em geral, logo após a aplicação, as plantas sensiveis apresentam cloroses nas folhas em desenvolvimento, formação de antocianinas nas folhas maduras, paralisação do crescimento, seguido pelo aparecimento de necrose nas zonas meristemáticas, tanto de folhas como de raizes (Gronwald, 1991). Em gramineas ocorre descoloração e desintegração dos tecidos próximos aos entrenós. Nas folhas jovens ocorre clorose e morte, entre uma e três semanas após o tratamento. Em folhas mais velhas verificam-se as coloraçōes roxa, laranja ou vermelha, confundindo-se com sintomas de deficiência de fósforo (Böger \& Sandaman, 1989; Ahrens, 1994). 
As revisōes publicadas sobre os herbicidas APP e CHD discutem aspectos relacionados ao modo e mecanismo de ação destes herbicidas (Walker et al., 1985; Shimabukuro, 1990). O "modo de ação" pode ser definido como a soma das respostas bioquímicas, fisiológicas e anatômicas que constituem a ação fitotóxica total do herbicida. Por isso, no estudo do modo de ação são considerados os efeitos primário e secundário, que devem explicar as respostas morfológicas e fisiológicas observadas na plantas, provocadas pelos herbicidas e sua ação fitotóxica. O "mecanismo de ação" é a principal reação bioquímica, processo biofisico ou lesão (enzima ou outro sítio de ação) afetada pelo herbicida. Um efeito no principal local de ação, pode ou não ser suficiente para provocar fitotoxicidade completa.

Dois mecanismos de ação têm sido propostos para os herbicidas APP e CHD: a) Mecanismo bioquímico, envolvendo a inibição da acetil-CoA carboxilase (ACCase) e subseqüente biossintese de ácidos graxos nos plástídeos (Burton et al., 1991); b) Mecanismo biofisico, envolvendo alteraçōes no gradiente de prótons através da membrana plasmática (Shimabukuro \& Hoffer, 1997).

\subsubsection{Inibição da biossintese de ácidos graxos}

A biossintese de ácidos graxos e lipídeos é essencial ao crescimento e desenvolvimento normal das plantas. Os lipídeos estão envolvidos na biogênese e na função de várias membranas na transferência celular e em outras funçōes fisiológicas (Ditomaso et al., 1993).

A sintese de lipídeos nas plantas ocorre no citoplasma celular, nos plastideos e cloroplastos. A primeira reação na rota metabólica da sintese de lipídeos envolve a carboxilação da acetil-CoA mediada pela acetil-CoA carboxilase (ACCase). Nesta reação o $\mathrm{CO}_{2}$ se liga à enzima; na seqüência a acetil-CoA se liga à enzima para então ocorrer a transferência do $\mathrm{CO}_{2}$ da enzima para a acetil-CoA (Diesenhofer \& Michel, 1989; Duke et al., 1991; Devine et al., 1993). 
Alguns aspectos da biossintese de ácidos graxos e lipídeos, ainda não são bem compreendidos pelos pesquisadores. No entanto, é aceito que a ACCase é a enzima chave que regula a biossintese de ácidos graxos Ela é caracterizada como alvo de ação do herbicida, baseado em detalhados ensaios in vitro e na correlação entre reações em planta inteira e sensibilidade da enzima.

A discussão sobre os mecanismos de ação dos herbicidas APP e CHD indica que, em tecidos intactos, os efeitos bioquímicos e biofisicos provavelmente ocorram simultaneamente, pelo menos durante as primeiras doze horas seguintes à aplicação do herbicida.

Os primeiros trabalhos de pesquisa para localizar o sitio de ação dos herbicidas do grupo químico APP foram desenvolvidos por Hoppe (1981), o qual demonstrou que o herbicida ácido diclofop (APP) interferia na biossintese de lipideos em radiculas de milho, ao impedir a formação de ácidos graxos por meio da inibição e da incorporação de acetado marcado. Hoppe (1981) demonstrou que o ácido diclofop, entretanto, não possuía apenas efeito na incorporação de outros precursores em ácidos nucleicos ou proteinas. Estudos posteriores (Burton et al., 1987) demonstraram que os APP são potentes inibidores desta reação em gramineas, porém não em dicotiledôneas e outras monocotiledôneas. Existem inúmeras evidências que apoiam a teoria dos herbicidas APP como inibidores da atividade da ACCase in vivo; além do efeito inibidor in vivo destes herbicidas tanto sobre a biossintese de lipideos (Hoppe, 1981) como na incorporação de $\left[{ }^{14} \mathrm{C}\right]$-acetado e piruvato nos ácidos graxos (Hoppe \& Zacher, 1982 e 1985) e a ainda, a inibição in vitro da atividade da ACCase em muitas gramineas (Gronwald, 1991).

A primeira evidência sobre os herbicidas APP como inibidores da sintese de lipideos foi verificada através da incorporação de [14C]-acetato em ácidos graxos livres de milho e em cloroplastos isolados de milho tratados com herbicidas APP (Hoppe \& Zacher, 1985), e em experimentos elaborados com ACCase de espécies com diferentes níveis de sensibilidade (Lichtenthader \& Kobek, 1987; Kobek et al., 1988). A incorporação de malonil-CoA aos ácidos graxos livres torna-os insensiveis a estes herbicidas (Kobek et al., 1987). 
Os estudos iniciais com os herbicidas do grupo quimico CHD, também mostraram que este grupo de herbicidas atuava no metabolismo de lipídeos ao reduzir o conteúdo de glucolipídeos e fosfolipideos em plântulas de milho (Burgstahler \& Lichtenthader, 1984). Posteriormente, outras evidências se somaram à esta hipótese quando se verificou que o sethoxydim e outros CHD inibiam a incorporação de acetato nos lipídeos de diferentes gramineas suscetiveis (Burton et al., 1987). Assim como nos APP, também se demonstrou nos CHD que a biossintese de lipídeos era mais intensivamente inibida pelo sethoxydim do que a sintese de RNA, DNA e proteinas (Ishihara et al., 1987).

Além disso, nem todos os tecidos de uma espécie de planta são igualmente sensiveis aos CHD. Dessa forma, o herbicida sethoxydim inibe rapidamente a incorporação de $\left[{ }^{14} \mathrm{C}\right]$-acetato nas extremidades das raizes (0-2 $\mathrm{mm}$ ), enquanto que não se encontrando inibição em regiōes de raizes mais espessas (10-15 mm) (Hosaka \& Takagi, 1987). Os estudos desenvolvidos a esse respeito chegaram à conclusão de que a ACCase se encontra presente em células que estão se dividindo rapidamente e em cloroplastos ativos. De acordo com estes estudos, os sintomas observados, provocados pela ação do herbicida, são mais fortes $\mathrm{e}$ atuam mais rapidamente em regiōes meristemáticas e nos cloroplastos. Os efeitos secundários da ação do herbicida, no nivel molecular, incluem clorose (inibição da biossintese de clorofila e carotenóides), alteração na distribuição de ácidos de cadeia longa no cloroplasto (diminuição de C-18 e incremento de $\leq$ C-16) e inibição da sintese de DNA e da mitose no nível celular.

Dos passos possiveis na seqüência catalitica normal de ação da ACCase, ou seja, a carboxilação da biotina e transcarboxilação (acetato $\rightarrow$ malonato), a última reação é a mais sensivel na inibição pelos herbicidas APP e CHD (Burton et al., 1991 e Rendina et al., 1990). As informaçōes sobre a inibição da enzima claramente indicam que os herbicidas APP e CHD são potentes inibidores reversiveis, lineares e não-competitivos da ACCase de espécies de gramineas e que a seletividade entre estas e as espécies dicotiledôneas ocorreu por causa da relativa insensibilidade da ACCase das dicotiledôneas, a estes herbicidas (Walker et al., 1989 e Gronwald, 1991). 
Com o objetivo de definir mais precisamente o local de ação dos APP e CHD, Burton et al. (1989) examinaram o efeito de haloxyfop e sethoxydim na incorporação de acetato, piruvato e malonil-CoA em ácidos graxos isolados de cloroplastos de milho. A incorporação de acetato e piruvato foi inibida em $90 \%$ ou mais, na presença de sethoxydim e haloxyfop nas concentraçōes de $10 \mu \mathrm{M}$ e $1 \mu \mathrm{M}$, respectivamente; enquanto que a incorporação de malonil-CoA foi ligeiramente estimulada nas mesmas concentraçōes. Com base nestes resultados, estes pesquisadores estudaram o efeito de haloxyfop e sethoxydim sobre a atividade da ACCase de cloroplastos de milho e ervilha e concluíram que estes herbicidas são potentes inibidores da ACCase cloroplástica em milho, porém não em ervilha. Estudos posteriores sobre a atividade da ACCase em suspensão de células de milho, demonstraram que existem diferenças na eficácia relativa dos herbicidas APP e CHD como inibidores desta enzima.

Os APP e CHD se translocam até as partes meristemáticas das gramineas, onde a divisão celular e a elongação de células demanda uma grande quantidade de malonil-CoA para a biossintese de ácidos graxos. A inibição na sintese de ácidos graxos poderia contribuir para os efeitos destrutivos da ultra estrutura dos plastideos (Brezeu et al., 1976; Lichtenthader \& Meier, 1984), da permeabilidade da membrana (AsareBoamah \& Fletcher, 1983) e para a necrose de zonas meristemáticas. Além disso, o malonil-CoA serve também como intermediário na sintese de ceras cuticulares, flavonóides, antocianinas, antraquinonas e estilbenóides (Nikolau et al., 1984; Stumpf et al., 1987).

\subsubsection{Alteraçāo no "gradiente de prótons da membrana"}

Ainda que as evidências a favor da ACCase como local de ação dos APP e CHD sejam numerosas, existem autores que propuseram um mecanismo de ação biofísico, baseado no efeito protonóforo dos herbicidas APP, que é capaz de alterar a permeabilidade da membrana plasmática de 
gramineas suscetiveis (Lucas et al., 1984; Wright \& Shimabukuro, 1987; Ratterman \& Balke, 1988).

Todas as células da planta estabelecem e mantêm um gradiente de prótons através da membrana, que é essencial ao seu crescimento e desenvolvimento (Powles \& Holtum, 1994). O gradiente de prótons é estabelecido (negativo no interior e positivo no exterior da membrana plasmática) pela $\mathrm{H}^{+}$-ATPase (bomba de prótons), requerendo energia que é conduzida pela hidrólise de ATP (Gronwald, 1991). Portanto, qualquer substância química ou xenobiótica, como o diclofop-methyl, que altera o gradiente de prótons através da membrana, pode apresentar efeitos significativos sobre inúmeros aspectos da fisiologia da planta (Shimabukuro, 1990).

Existem evidências que, em plantas e tecidos intactos, a rápida inibiçāo de crescimento e o efeito sobre a sintese de ácidos graxos sāo eventos distintamente separados (Shimabukuro, 1990).

Em condiçōes normais há uma diferença de $\mathrm{pH}$ e de carga elétrica entre o meio interno $(\mathrm{pH} 7,5)$ e o meio externo da célula $(\mathrm{pH} 5,5)(\Delta \mathrm{v}=$ $70 \mathrm{mV}$ ). Verificou-se a ocorrência de despolarizaçāo da membrana celular, após a aplicaçāo de herbicidas APP e CHD em plantas sensiveis, torna menores as diferenças entre o meio interno e externo às células, aumentando o gradiente (permeabilidade) de prótons através da membrana (Powles, 1994).

Shimabukuro \& Hoffer (1988), demonstraram que os ácidos derivados de diclofop despolarizam a membrana de coleóptilos e radículas de numerosas gramineas (Secale cereale, Triticum aestivum, Avena fatua e Lolium rigidum). Segundo estes autores, a despolarizaçāo se deve ao aumento no fluxo de prótons para o interior da célula, diminuindo o $\mathrm{pH}$ citoplasmático. A membrana plasmática é a barreira inicial, ou local de ação, que o diclofop e outros herbicidas APP encontram para agir. O éster lipofilico penetra na membrana plasmática concentrado numa dose maior que a dos ácidos livres anfolíticos. Além disso, o éster é rapidamente hidrolizado a um ácido ativo, resultando numa concentração citoplasmática de ácido, maior do que em 
células inicialmente tratadas com diclofop (Shimabukuro \& Hoffer, 1988 e 1992).

A ativação de ATPases por 2,4-D diminui o efeito despolarizador do diclofop, verificado pelo aumento na saída de prótons que restaura o potencial da membrana, com o custo de grande perda de energia (Holtum et al., 1994). O efeito antagônico do 2,4-D se observa no campo ao se utilizar algum APP ou CHD em mistura com aquele herbicida. O 2,4-D reduz o efeito dos herbicidas sobre as plantas daninhas suscetiveis, sendo este um dos argumentos da teoria da alteração no gradiente de prótons na membrama celular como causador do aumento da tolerância pelas plantas, o qual não se explica através da ACCase (Shimabukuro \& Hoffer, 1992).

Outros pesquisadores consideram que a falta de lipídeos na célula seja a causa da despolarização da membrana celular. Quando a ACCase presente nos cloroplastos é inibida, não ocorre a formação de lipídeos, prejudicando a formação e manutenção de membranas lipoproteicas para as diversas organelas e para a célula. Aproximadamente 5 a $10 \%$ do peso da fitomassa seca é formado por lipídeos, cuja maioria é encontrado como constituinte das membranas de organelas e das células (Diesenhofer \& Michel, 1989). A inibição da ACCase promoveria a inibição da sintese de lipídeos, que por sua vez danificaria as membranas celulares, causando a despolarização de membranas nas organelas e nas células.

Entre as principais alteraçōes provocadas pela diminuição do potencial da membrana celular destaca-se a diminuição na absorção de açúcares, aminoácidos e acetato, o que determina uma lentidão nos processos de biossintese de ARN, ADN, proteinas e lipideos (Hoppe, 1981; Peregoy \& Glenn, 1985; Sentenac \& Grignon, 1987 e Grignon \& Sentenac, 1991).

Os efeitos dessas alteraçōes a longo prazo são: perda da integridade da membrana com extravasamento dos eletrólitos e clorose causada por danos na membrana dos cloroplastos (Shimabukuro, 1990) e necrose das células meristemáticas, podendo ser causada pelos efeitos do mecanismo bioquimico ou uma combinação de ambos mecanismos. As 
interações bioquimicas e biofisicas entre os dois mecanismos, que levam a planta à morte, ainda nāo estāo claramente elucidadas.

Apesar de todo o exposto, parece que o mecanismo biofísico, nāo pode por si só comprovar o efeito fitotóxico dos herbicidas APP e CHD. Existem pesquisadores a favor da teoria da ACCase e outros a favor do mecanismo biofísico da alteraçāo do potencial da membrana. Outros pesquisadores propuseram teorias que tentam integrar ambas, argumentando que as duas podem coexistir simultaneamente na natureza (Devine \& Shimabukuro, 1994).

\section{RESISTÊNCIA DE PLANTAS DANINHAS A HERBICIDAS}

\subsection{Evoluçāo e desenvolvimento da resistência}

Devido ao seu grande potencial de uso agricola, as indústrias têm desenvolvido um grande número de novos herbicidas que sāo introduzidos na agricultura mundial a cada ano. A resistência a herbicidas em plantas daninhas é um exemplo da evoluçāo de espécies de plantas como conseqüência de alterações no ambiente, causadas pela açāo do ser humano. A exigência crescente do controle quimico de plantas daninhas tem levado ao aparecimento, da mesma maneira como ocorreu com insetos e microorganismos, do processo de resistência por parte das plantas.

Os registros atuais apontam a existência de 218 biotipos resistentes de plantas daninhas, distribuidos entre 145 espécies (Heap, 1999). Até 1997, os casos documentados de plantas daninhas resistentes eram de $28 \%$ para os herbicidas inibidores da ALS, $15 \%$ às triazinas, $15 \%$ aos bipiridilos, $12 \%$ às uréias e amidas, $11 \%$ aos inibidores da ACCase, $4 \%$ às dinitroanilinas e os demais casos distribuidos em diversas outras classes de herbicidas (Heap, 1999).

Apesar da existência de herbicidas nāo seletivos, que resultam ativos sobre a maioria das espécies daninhas, os mais importantes, 
quantitativa e qualitativamente são os herbicidas seletivos, capazes de controlar um amplo espectro de plantas daninhas sem afetar as culturas às quais se aplicam. A seletividade pode ocorrer por causas físicas ou mais freqüentemente, por causas fisiológicas e/ou bioquímicas, derivadas das diferenças genéticas existentes entre as espécies vegetais (Jäger, 1983).

A habilidade natural em tolerar uma substância tóxica, implicando em determinadas plantas cultivadas e também daninhas, serem capazes de sobreviverem e se desenvolver sob as doses recomendadas é definido como "tolerância", para uso agricola dos herbicidas (Jäger, 1983).

Devido à variabilidade genética intraespecifica, e à pressāo de seleçāo imposta pela aplicaçäo continua de herbicidas é possivel haver o desenvolvimento de biotipos de plantas daninhas que deixam de ser controlados por determinado produto, ao qual anteriormente eram sensiveis. Surge então o termo "resistência" para definir a capacidade natural e herdável de alguns biotipos de plantas daninhas de uma determinada população, em sobreviverem a tratamentos com herbicidas que deveriam controlar com eficácia esta população, sob condiçōes normais de uso (Gunsolus, 1993). Diferentemente das plantas tolerantes, as resistentes sobrevivem não somente a doses recomendadas para uso agricola do herbicida, como também a outras superiores. Esta definição admite que a resistência está associada unicamente a fatores físiológicos e/ou morfológicos.

As definiçōes apresentadas na literatura para diferenciar os termos "resistência" e "tolerância" de plantas daninhas a herbicidas são um pouco distintas. LeBaron \& Gressel (1982) ressaltam que o termo "tolerância" pode ser usado para definir não só as variaçōes entre espécies, como também relacionar as variaçōes dentro de uma mesma espécie. Neste caso, tolerância e resistência são expressōes que denotam diferenças na intensidade de um mesmo fenômeno, considerando-se a resistência como um caso extremo e menos freqüente de tolerância (Holt \& Le Baron, 1990), ou ainda considerando-se a tolerância como um fenômeno poligênico e a resistência como monogênico (Gressel, 1985). 
Holt \& LeBaron (1990) afirmam que qualquer definição de resistência deve relacionar-se com a utilização do herbicida, em sua doses de campo recomendada para o controle das plantas daninhas. Gressel \& Segel (1978) definiram como resistentes as plantas que sobrevivem a doses que normalmente controlam plantas suscetiveis da mesma espécie. Warwick (1991) definiu resistência como sendo o resultado da seleção ou da resposta genética a repetidas exposiçōes a herbicidas com mesmo mecanismo de ação. Sawicki (1987) propôs uma definição que, além de considerar o aspecto da dose recomendada, salienta o conceito de evolução afirmando que a resistência seria uma resposta genética à seleção imposta pelos herbicidas.

O termo "resistência" é comumente apresentado tanto com referência ao comportamento de um individuo frente aos mecanismos de resistência que possui, quanto aos herbicidas aos quais este individuo é resistente. Desta forma, surgem os conceitos de resistência cruzada e resistência múltipla. Existem diferentes definiçōes dependendo da associação destas a conceitos de mecanismos de resistência (Jutsum \& Graham, 1995) ou a grupos quimicos de herbicidas (Rubim, 1991). Segundo Jutsum \& Graham (1995).

A resistência cruzada, ocorre quando um individuo é resistente a dois ou mais herbicidas, devido a um só mecanismo de resistência, e a resistência múltipla ocorre quando um individuo possui dois ou mais mecanismos de resistência que conferem o comportamento resistente a um ou vários herbicidas. Tardif et al. (1993) identificaram biotipos de Lolium rigidum que apresentavam resistência cruzada tanto a herbicidas do grupo quimico APP quanto aos CHD, devido à insensibilidade da ACCase à ação dos herbicidas. Em outros trabalhos, um mesmo biotipo de Lolium rigidum apresentou mecanismos de resistência por causa da "resposta de recuperação da membrana" (Häuler et al., 1991); devido ao acréscimo no metabolismo de diclofop-methyl (Holtum et al., 1991) e a insensibilidade da ACCase (Mattews et al., 1990), exemplificando assim um caso de resistência múltipla.

Baseando-se em grupos quimicos de herbicidas, Rubim (1991) definiu resistência cruzada como aquela na qual uma população é resistente a 
dois ou mais herbicidas que atuam sobre o mesmo sítio primário de açāo, e resistência múltipla como aquela na qual uma populaçāo apresenta resistência a dois ou mais herbicidas que atuam em diferentes sítios primários de açāo.

Nesta tese, os termos tolerāncia e resistência foram utilizados com os significados apresentados por Jäger (1983). Quanto aos termos "resistência cruzada" e "múltipla", foram utilizadas os propostos por Jutsum \& Graham (1995), que foram os melhores adaptados ao material vegetal utilizado.

Desde o aparecimento dos primeiros casos de resistência de herbicidas a plantas daninhas, tem-se procurado conhecer os fatores determinantes no desenvolvimento destes processos. Os fatores mais importantes seriam: tempo de geraçāo (número de ciclos por ano), a freqüência inicial dos biotipos resistentes presentes numa populaçāo (Gressel \& Segel, 1982); o tipo de pressāo de seleçāo (eficiência e persistência do herbicida, intensidade de utilizaçāo, eficácia dos mecanismos de resistência, etc...) (Gressel \& Segel, 1990; Gressel, 1991; Rubim, 1991); adaptabilidade ecológica das populaçōes resistentes (Silvertown, 1987; Holt, 1995) e a germinaçāo espacial e temporal do banco de sementes no solo (Gressel \& Segel, 1990). Dentre estes fatores, a pressāo de seleçāo imposta pelos herbicidas e o manejo do banco de sementes do solo sāo os únicos que podem ser alterados pela atividade humana (Cussans, 1996).

Fatores como o maior tempo na geraçāo das plantas (normalmente uma geraçāo por ano agrícola), em comparaçāo com o de insetos e fungos, e a maior eficácia controladora dos herbicidas (maior pressāo seletiva), avaliada em torno de $90-95 \%$ em relaçāo aos demais agroquimicos, foram responsáveis pelo processo mais lento de resistência por plantas daninhas a herbicidas. $\mathrm{O}$ fato de as sementes que compōem o banco de sementes de várias espécies de plantas daninhas germinarem durante vários anos também pode determinar o lento aumento da populaçāo de plantas resistentes, uma vez que os individuos que aparecem em cada estaçāo sāo conseqüência nāo só das plantas que completaram seu ciclo no último ano, como também dos propágulos existentes no banco de sementes do solo, proveniente de geraçōes anteriores. 
As caracteristicas especificas dos herbicidas utilizados também podem influenciar na velocidade com que se desenvolvem os fenômenos de resistência. LeBaron (1988) destaca em ordem de importância: um único local de ação e atuação específica; alta atividade e efetividade no controle de um amplo espectro de espécies de plantas daninhas; alta persistência no solo; aplicação freqüente e por vários anos agrícolas sem rotação, alternância ou combinação com outros tipos de herbicidas com diferentes mecanismos de ação.

Estudos de população realizados com biotipos de Alopecurus myosuroides de áreas agrícolas da Inglaterra, demonstraram que o desenvolvimento de populaçōes resistentes é mais influenciado pelo contínuo aumento da taxa do nivel de resistência a herbicidas em todos os individuos da população estudada, do que pelo aumento da proporção de indivíduos altamente resistentes (Moss \& Cussans, 1991). Este acréscimo da taxa do nivel de resistência é caracterizado pela presença de variaçōes tanto entre os individuos de uma mesma população como entre populaçōes diferentes, ainda que não existam reposiçōes de populaçōes resistentes e suscetiveis aos herbicidas. Deste modo, os individuos mais tolerantes aos herbicidas, das populaçōes sensiveis, suportam doses menores que os mais sensiveis das populaçōes resistentes (Moss \& Cussans, 1991). Com isso, evidencia-se a existência de diferentes níveis de resistência entre populaçōes, em função do herbicida utilizado (Moss, 1990).

\subsection{Resistência de plantas daninhas a herbicidas inibidores da acetil coenzima A carboxilase (ACCase)}

As primeiras referências de plantas resistentes aos APP e CHD surgiram após 7-10 anos da introdução destes herbicidas no mercado (Heap \& Knigth, 1982; Thai et al., 1985). Ainda que a distribuição atual da resistência de plantas daninhas a estes herbicidas seja dificil de ser dimensionadas, 
existem registros de pelo menos 11 espécies que apresentam biotipos resistentes a e estes produtos (Tabela 4).

Tabela 4. Espécies de plantas daninhas relatadas que apresentam biotipos resistentes aos herbicidas APP e CHD (Devine, 1997).

\begin{tabular}{ll}
\hline Espécie & País \\
\hline Alopercurus myosuroides & Reino Unido, Alemanha, Espanha e França \\
Avena fatua & Canadá, EUA, Austrália \\
Avena sterilis & Austrália, Reino Unido \\
Digitaria sanguinalis & EUA \\
Echinochloa colonum & Costa Rica \\
Eleusine indica & Malásia \\
Lolium multiflorum & EUA, França, Reino Unido \\
Lolium rigidum & Austrália, Espanha \\
Setaria viridis & Canadá \\
Setaria faberii & EUA \\
Sorghum halepense & EUA \\
Brachiaria plantaginea & Brasil \\
\hline
\end{tabular}

* Adicionado à tabela original.

A ocorrência dos casos de resistência está sempre associada ao uso repetitivo dos herbicidas, de um ou ambos grupos quimicos, por vários anos seguidos. Apesar dos levantamentos serem de baixa precisão, o número estimado de locais com plantas de $L$. rigidium resistentes na Austrália é acima de 3000 e os locais com Avena spp resistente no Canadá e Austrália são acima de 100. É provável que nestas e em outras populações, exista uma baixa freqüència de individuos resistentes estejam presentes em populações não selecionadas e que a aplicação repetida dos APP ou CHD promovam seleção para resistência, alterando as populações até que elas passem a ser compostas predominantemente de plantas resistentes (Powles \& Holtum, 1994).

Apesar da freqüente dificuldade em se determinar o histórico do uso de herbicidas, é notável que a seleção por mais de quatro anos seja 
suficiente em alguns casos, para originar populaçōes resistentes. De qualquer modo, nas situaçōes em que os herbicidas possam ser aplicados mais de uma vez por ano, este periodo de seleçāo pode ser reduzido (Powles \& Holtum, 1994).

Atualmente, entre as espécies daninhas resistentes aos herbicidas inibidores da ACCase, as mais estudadas sāo L. rigidum e $A$. myosuroides.

A natureza alógama de algumas espécies daninhas, junto com a dispersāo em áreas cultivadas, tem contribuído para o desenvolvimento de resistência múltipla de tais espécies. Populações de L. rigidum podem apresentar mais de um mecanismo de resistência, sendo que individuos dentro de uma mesma populaçāo podem diferir em sua composiçāo genética para a resistência. Trabalhos desenvolvidos com a espécie $A$. myosuroides resistente ilustram que a acumulação de mecanismos de resistência dentro de uma populaçāo, nāo sāo exclusivos para a espécie L. rigidium (Moss \& Cussans, 1991; De Prado et al., 1991)

A resistência em L. rigidum, apresenta um complexo padrāo desenvolvido com o uso de vários grupos diferentes de herbicidas. Para algumas populações resistentes há somente um grupo de herbicidas, enquanto que em outras existem vários grupos de herbicidas e modos de açāo. Por exemplo, de 242 populações resistentes testadas na Austrália, 39 delas e 11\% apresentavam resistência somente aos herbicidas sulfoniluréias e APP, respectivamente. Contudo, 32\% foram resistentes a ambos, sulfoniluréias e APP; $12 \%$ a sulfoniluréias, APP e CHD e $6 \%$ foram resistentes a APP e CHD (Hall et al., 1994). A resistencia múltipla que ocorre neste caso para vários herbicidas com diferentes mecanismos de açāo, representa um problema para o controle químico.

Os padrōes de resistência dentro das espécies sāo variáveis. Por exemplo, embora a maioria das linhagens de $A$. fatua resistentes, provenientes do Canadá, sejam resistentes aos herbicidas inibidores da ACCase, o grau relativo de resistência para diferentes produtos pode variar entre as linhagens. 
Em alguns casos existe um alto nivel de resistência aos herbicidas APP e nenhuma resistência aos herbicidas CHD.

Resultados semelhantes têm sido observados em L. rigidum, sendo comum serem encontrados mais padrōes diferenciados de resistência cruzada, quanto mais biotipos resistentes aos herbicidas são caracterizados (Heap \& Knight, 1990; Heap et al., 1993).

$\mathrm{Na}$ Inglaterra vários biotipos de $A$. myosuroides, apresentam resistência ao diclofop-methyl e ao fenoxaprop-ethyl, porém, o nivel e o alcance da resistência a outros APP variam consideravelmente (Preston et al., 1992). Dois destes biotipos são resistentes aos APP diclofop-methyl, fenoxaprop-ethyl e fluazifop-butyl e ao CHD tralkoxydim, mas somente ligeiramente resistentes ao sethoxydim (Sasaki et al., 1995).

\subsection{Resistência de plantas daninhas a herbicidas no Brasil}

Desde o primeiro biotipo de Daucus carota resistente a 2,4-D encontrado nos EUA, em 1957 (Whitehead \& Switzer, 1963), a resistência a herbicidas tem sido um fenômeno em continua progressão. As últimas estimativas registram a existência de biotipos resistentes em pelo menos 52 espécies de plantas daninhas na Europa (De Prado et al., 1997), 55 nos EUA (Shaner, 1997) e 38 no restante do mundo (Rubim, 1997).

$\mathrm{O}$ primeiro caso de planta daninha resistente a herbicidas documentado no Brasil, foi com a planta daninha picão-preto (Bidens pilosa) em regiōes produtoras de soja (Ponchio et al., 1996). Populaçōes de Bidens pilosa (Christoffoleți et al., 1996); Euphorbia heterophylla (Gazziero et al., 1998) e Bidens pilosa/Bidens subalternans (Monqueiro, 1999) resistentes aos herbicidas inibidores da ALS; e Brachiaria plantaginea (Vidal \& Fleck, 1997; Gazziero et al., 1997; Christoffoleti et al., 1998 e Cortez et al., 1999) resistente aos herbicidas inibidores da ACCase, foram confirmadas em regiōes produtoras de soja no Brasil. Ponchio (1997) confirmou a existência de 
populaçōes de Bidens pilosa resistentes a herbicidas inibidores da ALS, nos Estados de Mato Grosso do Sul e Rio Grande do Sul.

No Brasil há poucos relatos e pesquisas que determinam a real extensão da área afetada por plantas daninhas resistentes aos herbicidas. Sabe-se, entretanto, que o surgimento deste fenômeno ocorre na maioria das vezes, em áreas onde são utilizados repetidamente e de maneira consecutiva, os mesmos herbicidas ou herbicidas com mecanismo de ação. Esta situação tem sido comum no Brasil, especialmente em áreas com cultivo de soja.

No caso de desenvolvimento de dicotiledôneas resistentes, este fenômeno possivelmente estará relacionado ao fato da soja ser uma cultura bastante sensivel às perdas provocadas pela competição com as plantas daninhas e geralmente por ser conduzida em extensas áreas, exigir a utilização freqüente do controle quimico das invasoras através de herbicidas.

O desenvolvimento de gramineas resistentes tem sido verificado em áreas de produção de soja cultivadas no sistema de semeadura direta, o que impossibilita a integração de outras técnicas de manejo de plantas daninhas ou a utilização de diferentes métodos de controle, além do químico. Neste caso, o problema se torna ainda mais grave quando se verifica a intensidade com que os graminicidas de aplicação em pós-emergência, seletivos à soja, têm sido aplicados ao longo dos anos. Isso ocorre por causa da dificuldade de se utilizar graminicidas pré-emergentes, pois apresentam elevada retenção na matéria orgânica, abundantemente presente no solo, em áreas de semeadura direta.

A cultura da soja é também a que responde pelo maior consumo de herbicidas no Brasil (Sindag, 1999) e a que se utiliza desta técnica de controle há mais tempo, desde a introdução da cultura no Brasil.

Ainda que algumas informaçōes não publicadas, façam referência a um continuo aumento da superficie agricola afetada, a extensão real das zonas infestadas por biotipos de plantas daninhas resistentes a herbicidas está mal documentada devido à falta de levantamentos criteriosos e registros de casos cientificamente comprovados. No entanto, a importância crescente que o fenômeno da resistência a herbicidas apresenta na agricultura brasileira tem 
motivado tanto de órgãos oficiais como as empresas produtoras de herbicidas a realizarem prospeções para quantificar a magnitude do problema (CBRPH $\left.{ }^{1}\right)$.

\section{MECANISMOS DE RESISTÊNCIA DE PLANTAS A HERBICIDAS}

Quando populações de plantas daninhas que apresentam variabilidade genética são tratadas intensivamente com um mesmo herbicida, ou com produtos de mesmo mecanismo de ação, poderão ocorrer sobreviventes com mecanismos de resistência diversificados (Powles \& Holtum, 1994).

Populações resultantes desta seleção podem ser compostas de individuos com caracteristicas genéticas relacionadas à resistência. Os herbicidas podem atuar como agentes de seleção dentro de uma população, para traços característicos herdáveis, possibilitando a sobrevivência de individuos em contato com esses produtos. Para isso, os mecanismos de sobrevivência precisam ser suficientemente eficazes para permitir a sobrevivência das plantas sob doses recomendadas dos herbicidas utilizados. Desta forma, plantas com algum mecanismo de resistência geneticamente transmitido sobreviverão e contribuirão para a reserva de genes na população.

A reproduçāo sexuada em espécies de plantas daninhas é importante na constituição do tipo de resistência que uma população pode desenvolver. Em espécies autógamas existe menor probabilidade de ocorrência de mais de um mecanismo de resistência em uma mesma planta, em função da autopolinização, que dificulta o fluxo de genes entre plantas vizinhas. Em espécies alógamas existe maior probabilidade de ocorrência de múltiplos mecanismos de resistência, pois a polinização cruzada permite maior recombinação gênica. Deste modo, seleções sucessivas podem acumular mecanismos de resistência dentro de individuos e reduzir a freqüência de genes susceptiveis na população. Individuos com mais de um mecanismo serão provavelmente mais resistentes a aplicações de herbicidas com diferentes

\footnotetext{
${ }^{1}$ CBRPH - Comitê Brasileiro de Resistência de Plantas aos Herbicidas. Ata de reunião em 01/10/1999 Ponta Grossa/PR.
} 
mecanismos de ação. Com isso, é possivel verificar a existência de diferentes tipos de resistência (Rubim, 1991; Devine et al., 1993a; Jutsum \& Graham, 1995).

Existem pelo menos três mecanismos gerais que podem explicar o desenvolvimento da resistência a herbicidas (Sherman et al, 1996) e influenciar o modo de ação destes compostos: a) redução da concentração do herbicidas no local de ação, absorção foliar e/ou translocação do herbicida pelo biotipo resistente; b) metabolização ou destoxificação do herbicida a substâncias menos fitotóxicas; c) perda de afinidade do herbicida pelo local de ação na enzima.

\subsection{Reduçāo da concentraçāo do herbicida no local de açāo}

Uma das condiçōes necessárias para a melhor atuação de um herbicida é que ele alcance o local de ação na planta, em uma concentração suficiente para que ocorra o controle. O local de ação pode estar situado longe do local de aplicação do herbicida. Por exemplo, o herbicida pode necessitar ser translocado desde as folhas até os meristemas apicais para tornar-se efetivo. Então, o bloqueio do movimento ao local de ação pode ocorrer na superficie de contato inicial (na cuticula da folha ou na epiderme da raiz), dentro da planta (parede celular ou membrana plasmática) ou nos tecidos vasculares por onde ocorrem a translocação do herbicida.

A movimentação deficiente de um herbicida, em alguns biotipos de plantas daninhas, pode reduzir a concentração deste no local de ação e ser responsável pela resistência ao herbicida na espécie estudada. Estas baixas concentraçōes podem ocorrer por causa da redução na retenção do herbicida pela superficie foliar, redução da absorção e/ou translocação na planta, ou pela ocorrência de fenōmenos de seqüestração em organelas celulares metabolicamente inativas (Powles \& Holtum, 1994).

Alguns autores afïmam que a deficiência de movimentação do herbicida na planta, em razão da absorção e/ou translocação reduzidas pode 
ser a causa da maior tolerância em inúmeras culturas e plantas daninhas (Tryee et al., 1979; Hess, 1985; Ladlie, 1991). Quando é possivel serem estudadas separadamente, os mecanismos de resistência em razāo da absorçāo e/ou translocaçāo sāo difíceis de serem interpretados apresentam dificuldades de interpretaçāo devido a dois fatores: 1) a absorçāo diferencial costuma resultar em uma translocaçāo diferencial; 2) a translocaçāo diferencial pode ocorrer por degradaçāo diferenciada do herbicida no local de absorçāo, resultando em metabólitos pouco ou muito translocáveis (Menendez, 1997).

O modo de absorçāo de um herbicida é determinado pelo seu modo de aplicaçāo podendo ser em pré-emergências (absorçāo via radicular) ou em pós-emergência (absorçāo via foliar). A quantidade de herbicida absorvida pela planta está relacionada com a quantidade de produto que fica retido nas folhas. Esta quantidade depende de fatores, tais como: condiçōes meteorológicas durante a aplicaçāo; tensāo superficial da soluçāo herbicida; volume de aplicaçāo utilizado na pulverizaçāo e caracteristicas foliares como área, orientaçāo e cerosidade .

Os herbicidas APP e CHD são rapidamente absorvidos pelas folhas das plantas, porém alguns representantes destes grupos necessitam da adiçāo de surfactante para melhorar a absorçāo pelas folhas. A absorçāo destes herbicidas e conseqüentemente a sua atividade, podem ser limitadas quando aplicados em mistura com herbicidas inibidores de "protox", sulfoniluréias, 2,4-D e bentazon, ou quando as plantas daninhas estão sob condiçōes de estresse hídrico (Ladlie, 1991; Rodrigues \& Almeida, 1998).

As causas da tolerância a herbicidas por falta de translocaçāo em plantas tratadas em pós-emergência nāo sāo ainda bem conhecidas. Apesar disso, foi possivel identificar a baixa eficiência na desesterificaçāo de herbicidas APP (pouco translocáveis via simplasto) em suas correspondentes formas ácidas (translocáveis via simplasto) como causa de tolerância de várias culturas (Jeffcoat \& Harries, 1975; Shaner et al., 1983).

Os fenômenos de compartimentalizaçāo, compreendidos como a seqüestração do herbicida ou de seus metabólitos em um local específico da 
célula, são mecanismos de tolerância/resistência pouco conhecidos porque evidências que os apoiam são, em muitos casos, circunstanciais (Coupland, 1991 e Owen, 1991).

Acredita-se que algumas espécies de plantas daninhas apresentam biotipos resistentes aos herbicidas inibidores da ACCase, com mecanismo de resistência decorrente da seqüestraçāo. A hipótese de seqüestraçāo ou compartimentalizaçāo intracelular do herbicida foi proposta para explicar o comportamento de um biotipo de Avena Fatua resistente aos inibidores da ACCase, que consegue se recuperar dos efeitos fitotóxicos dos herbicidas (Holtum et al., 1991). Membranas de biotipos resistentes e suscetiveis mantidas in vitro com concentração constante de herbicida no meio, nāo repolarizaram. Quando a concentraçāo de herbicida do meio foi diminuida, ocorreu a repolarizaçāo das membranas do biotipo resistente (Devine et al., 1993b).

Existe um biotipo de Avena fatua no Canadá no qual também foi encontrada a repolarizaçāo da membrana como mecanismo primário de resistência (Devine \& Shimabukuro, 1994). Em estudos realizados in vitro observou-se que em plantas resistentes e suscetiveis àqueles herbicidas, ocorre despolarizaçāo da membrana celular logo após a aplicaçāo dos produtos. Entretanto, no decorrer do tempo, as plantas resistentes repolarizam a membrana celular, enquanto que nas plantas suscetiveis a despolarizaçāo se acentua, ocorrendo o extravasamento do conteúdo celular. A capacidade de repolarizar a membrana decorre, provavelmente, da seqüestração do herbicida nos vacúolos, reduzindo a concentraçāo do mesmo no citoplasma e no cloroplasto (Devine et al., 1993b).

\subsection{Metabolismo e destoxificação do herbicida}

A resistência de biotipos de plantas daninhas, em razāo do metabolismo do herbicida a compostos não fitotóxicos, é um mecanismo de 
resistência em que a planta degrada o herbicida antes que este cause danos irreversiveis à ela.

A velocidade de metabolizaçāo pode variar com o estádio de desenvolvimento da planta e com a temperatura a que está exposta, entre outros fatores. Assim, uma mesma quantidade de herbicida aplicada a uma espécie pode tornar-se fitotóxico sob determinadas condiçōes e nāo produzir nenhum dano em outras. Os produtos da degradaçāo dos herbicidas costumam apresentar uma atividade muito pequena ou nula, exceto no caso dos pró-herbicidas que sāo metabolicamente ativados na planta (Duke et al., 1991). Alguns herbicidas exercem seus efeitos com a produçāo de outras moléculas tóxicas na planta. A resistência a estes herbicidas pode algumas vezes, ser atribuida à destoxificaçāo metabólica destes compostos tóxicos.

O mecanismo de destoxificaçāo dos herbicidas APP e CHD nāo é muito encontrado na natureza, contrariamente ao que ocorre com outros herbicidas. O mecanismo de destoxificaçāo mais conhecido é o que ocorre na planta de trigo para metabolizar o diclofop. O metabolismo e destoxifícaçāo do diclofop-methyl em plantas resistentes ocorre através da aryl-oxidaçāo e conjugaçāo (Shimabukuro, 1990). O trigo é naturalmente tolerante ao diclofop por causa de a forma ácida deste herbicida ser rapidamente aril-hidroxilada, após a desesterificaçāo do éster na planta, e posteriormente aril-glicolisada (Devine \& Shimabukuro, 1994). O trigo, embora tolerante ao diclofop, é suscetivel a outros APP e CHD pois o processo de destoxificaçāo destes herbicidas é menos intenso.

Marles et al. (1993) verificaram que a desestenificaçāo do fenoxaprop-ethyl para ácido foi levemente mais rápida em Setaria viridis suscetivel, que na espécie resistente, embora tenham concluido que a diferença foi pequena demais para contribuir significativamente para a resistência. Neste caso, a grande diferença de sensibilidade entre as ACCases de populaçōes resistentes e suscetiveis foi o principal mecanismo de resistência.

Observou-se a metabolizaçāo de diclofop em plantas daninhas suscetiveis de Avena fatua, ainda que, neste caso, formando menor quantidade 
de aril-glucosídeo e menr quantidade de éster-glucosídeo, o que não determina um comportamento tolerante. $\mathrm{O}$ éster pode liberar facilmente o ácido nos tecidos prolongando a presença do agente fitotóxico na planta (Devine \& Shimabukuro, 1994).

Alguns biotipos de L. rigidum, nos quais a resistência não está associada a ACCase insensivel aos herbicidas (Mattews et al., 1990; Holtum et al., 1991), apresentam um ligeiro acréscimo nas taxas de metabolismo do diclofop-methyl; contudo, o aumento da destoxificação não foi considerado suficiente para conferir o alto nivel de resistência por parte desses (Holtum et al., 1991; Shimabukuro \& Hoffer, 1991).

Foram descritos dois biotipos resistentes a diclofop, um de Alopecurus myosuroides e outro de Lolium rigidum, nos quais existe um aumento de destoxificação de diclofop ácido para formar principalmente arilglucosídeos, como ocorre com o trigo (Menendez et al., 1993 e 1996).

Em estudo com diferentes populaçōes de Avena fatua, no Canadá, não foi detectada nenhuma diferença nas taxas de metabolização ou rota metabólica de diclofop-methyl e fenoxaprop-ethyl, entre biotipos resistentes e suscetiveis (Devine et al., 1992; Devine et al., 1993).

Em trabalho realizado com biotipos de Alopecurus myosuroides da Espanha, Menendez \& De Prado (1996) verificaram que tanto o biotipo resistente como o suscetivel apresentaram padrōes idênticos de metabolismo de diclofop-methyl. No entanto, o biotipo resistente acumulou até $50 \%$ menos metabólitos fitotóxicos que o suscetivel, determinando ser esta a possivel causa da resistência cruzada a este herbicida.

Dois biotipos resistentes de Alopecurus myosuroides ingleses, apresentaram aumento na metabolização do diclofop-methyl e fenoxapropethyl por causa de resistência deles (Hall et al., 1994). Após vinte e quatro horas da aplicação de diclofop-methyl, o biotipo suscetivel apresentou $48 \%$ do ácido diclofop herbicidicamente ativo, 3\% do diclofop-methyl e 49\% de metabólitos dos herbicidas; enquanto que os biotipos resistentes apresentaram, em média, 28\% de ácido diclofop, 3\% de diclofop-methyl e 69\% de metabólitos (Hall et al., 1994). Foram encontradas em biotipos de L. rigidum 
com ACCase resistente, taxas de metabolismo de sethoxydim, fluazifop e haloxyfop semelhantes às encontradas em biotipos com ACCase sensivel. Mesmo passados sete dias após a aplicação destes herbicidas, quando plantas resistentes de $L$. rigidum estão saudáveis e apresentam fitomassa quatro vezes maior que o de plantas suscetiveis, não houve diferenças quanto ao metabolismo destes compostos (Tardif et al., 1993).

\subsection{Perda de afinidade do herbicida pelo local de ação na ACCase}

De maneira geral, os efeitos fitotóxicos dos herbicidas sobre as plantas resultam da sua atuação sobre um local de ação principal, geralmente uma proteina, de especial importância biológica. Este local é específico e a ação do herbicida sobre ele (efeito principal) freqüentemente conduz ao desenvolvimento dos efeitos secundários que normalmente acabam levando a planta à morte (Corbett et al., 1984). Uma ou várias mutações genéticas que resultam em mudanças de aminoácidos no local de ação, podem resultar na perda de afinidade do herbicida por este, impedindo a união efetiva de ambos e, conseqüentemente, a inibição do processo biológico mediado por este local de ação (Devine \& Shimabukuro, 1994; Gronwald, 1994; Saari et al.; 1994).

Os casos mais freqüentes de resistência aos herbicidas APP e CHD em culturas e plantas daninhas são explicados com base na resistência em virtude de alterações no local de ação. A ACCase de gramineas suscetiveis é sensivel à inibição pelos herbicidas APP e CHD, e a enzima ACCase de espécies dicotiledôneas resistentes não são afetadas. Mutações em milho resultaram na variabilidade de ACCase resistente ao haloxyfop e sethoxydim (Boldt \& Barret, 1991).

Pesquisas recentes sobre o mecanismo de resistência das plantas daninhas a herbicidas em Setaria viridis, Lolium rigidum, Avena sterilis e Sorghum halepense têm revelado formas alteradas de ACCase que são pouco sensiveis aos herbicidas APP e CHD. Até o momento não foi comprovado se as alteraçōes da ACCase em todos os biotipos resistentes é decorrente de um 
único tipo de material genético. Estudos com um biotipo de Alopecurus myosuroides resistente a herbicidas APP e CHD revelaram que nāo existem diferenças significativas na sensibilidade da ACCase entre biotipos resistente e suscetivel (Menendez \& De Prado, 1996). De qualquer modo, os padrōes variáveis de resistência aos diferentes inibidores da ACCase, descritos para planta inteira, sugerem previamente que podem estar envolvidas diferentes mutaçōes (Devine \& Shimabukuro, 1994).

\subsection{Outros mecanismos de resistência}

Além dos mecanismos de resistência descritos anteriormente, existem outros, como a despolarizaçāo da membrana. O mecanismo de resistência a estes herbicidas, os quais toleram alteraçōes nas propriedades da membrana plasmática foi descrito em biotipos de Lolium rigidum resistentes ao diclofop-methyl (Heap \& Knight, 1982; Matthews et al., 1990). Descriçōes semelhantes foram observadas em biotipos de Avena sterilis (Devine, 1992; Holtum, 1992). Em ambos casos, os biotipos resistentes apresentavam niveis considerados normais de ACCase sensivel aos herbicidas. Também foram observadas pequenas diferenças ou nenhuma na absorçāo, translocaçāo ou metabolismo dos herbicidas, na comparaçāo entre biotipos resistentes e suscetiveis (Holtum et al., 1991; Devine, 1992). Portanto, estes casos de resistência a herbicidas parecem estar correlacionados com alteraçōes no potencial da membrana após o tratamento das plantas com os herbicidas (Häuler et al., 1991; Shimabukuro \& Hoffer, 1991; Devine, 1992).

Os estudos realizados em algumas dicotiledôneas como girassol, mostraram que o diclofop nāo polariza a membrana plasmática, o que explica, segundo a hipótese do mecanismo de açāo biofísico explica seu comportamento resistente (Shimabukuro \& Hoffer, 1990 e Shimabukuro, 1990). A ausência de despolarizaçāo indica que nestas espécies nāo existem receptores especificos do herbicida, o que determina a sua tolerância. Em plantas daninhas, a despolarizaçāo seguida de uma recuperaçāo (ou repolarizaçāo da membrana) 
explica alguns casos de tolerância até o momento, sem definição pela tolerância à ACCase cloroplástica. Foram descritos um biotipo de Lolium rigidum e outro de Avena fatua resistentes ao diclofop, nos quais a concentração de herbicida necessária para despolarizar a membrana foi maior que a necessária para a despolarização em populaçōes suscetiveis (Häusler et al., 1991; Holtum et al., 1991; Devine et al., 1992).

Ao observar-se a despolarização em todos os casos, deduz-se que tanto biotipos resistentes como suscetiveis possuem locais de ação similares, dependendo da concentração de herbicida. No entanto, só no caso de biotipos resistentes foi observada a repolarização ao se retirar o herbicida do meio externo (Shimabukuro \& Hoffer, 1992; Devine et al., 1993b; De Prado et al., 1997). O mecanismo que explica a capacidade de repolarização é ainda desconhecido com base em uma destoxificação ou metabolização do herbicida.

O panorama geral é, diante do exposto, bastante complexo. A seletividade em dicotiledôneas, parece ocorrer em função de uma isoforma de ACCase cloroplástica (multimérica) diferente da existente em gramineas (multifuncional), a qual exibe uma baixa sensibilidade aos herbicidas APP e CHD. Em plantas cultivadas gramineas, a tolerância apresentada por algumas espécies deve-se à capacidade de metabolização da forma tóxica do herbicida (Devine \& Shimabukuro, 1994). Em plantas daninhas gramineas o mecanismo de resistência mais propagado é o que ocorre a partir de uma forma modificada de ACCase cloroplástica (multifuncional) (Gronwald et al., 1992; Mansooji et al., 1992; Tardif et al., 1993; Stoltenberg et al., 1993; Smeda et al., 1993; Marshall et al., 1994; Giménez-Espinosa et al., 1997b). Existem biotipos resistentes de $L$. rigidum, nos quais somente a capacidade de repolarização da membrana explica sua resistência (De Prado et al., 1973). Além disso, a complexidade do assunto aumenta diante do fato de existirem numerosos casos de dicotiledôneas com ACCase multimérica altamente resistente, nas quais não se observa despolarização (ervilha); dicotiledôneas com ACCase multimérica que detoxificam (soja); biotipos de gramineas com ACCase multifuncional resistente capazes de repolarizar e biotipos de gramineas que 
possuem ACCase resistente que metabolizam e repolarizam a membrana ao mesmo tempo (Devine \& Shimabukuro, 1994).

\section{A PLANTA DANINHA Brachiaria plantaginea}

A planta Brachiaria plantaginea possui como nomes vulgares mais conhecidos: capim-marmelada ou capim-papuã. Sua origem é provavelmente africana, tendo sido introduzida no Brasil nos tempos coloniais. É uma das espécies infestantes mais freqüentes nos solos cultivados das regiōes Centro e Sul do Brasil, tanto em culturas anuais quanto em perenes (Lorenzi, 1991). Infesta várias culturas no Brasil, sendo particularmente mais importante em culturas de soja e milho. Foi considerada por Blanco (1975) como uma planta infestante altamente nociva.

Sua presença na lavoura afeta diretamente a produtividade. Em condições de solo fértil o desenvolvimento pode ser tão vigoroso que uma planta por metro quadrado pode reduzir em até $50 \%$ do rendimento da soja (Kissmann \& Groth, 1991). Os prejuizos podem variar segundo a arquitetura e o ciclo da cultura, bem como a duração do periodo de competição. As populações de $B$. plantaginea. têm um ciclo mais longo que o das culturas anuais, sendo capazes de produzir grande massa foliar, e isso pode prejudicar o funcionamento de máquinas durante a colheita, além de aumentar as impurezas e a umidade nos grãos. Em uma área com alta infestação, se forem eliminados $98 \%$ das plantas, ainda assim as sobreviventes garantirão a continuidade do problema (Kissmann \& Groth, 1991).

Brachiaria plantaginea, segundo Kissmann \& Groth (1991), é uma planta anual, herbácea, ereta ou ocasionalmente ascendente, glabra, com enraizamento nos nós inferiores quando em contato com o solo, medindo entre 50 e $80 \mathrm{~cm}$ de altura. Apresenta inflorescência em paniculas ascendentes de 10 a $30 \mathrm{~cm}$ de comprimento e fecundação cruzada, sendo o pólen transportado pelo vento. É uma planta prolifica, e as sementes são o seu principal meio de disseminação. Após a maturação, as sementes produzidas em grandes 
quantidades, caem prontamente das espiguetas (Gillet, 1984), tendo um importante papel na dinâmica populacional desta espécie, tendo sido observado que elas se encontram dormentes na época de sua dispersão, portanto, com dormência primária.

As sementes de $B$. plantaginea apresentam baixa viabilidade logo após a maturação, sendo que a dormência de suas sementes ocorre devido à impermeabilidade do tegumento (Freitas, 1991). Esta caracteristica torna necessária a utilização de técnicas para superação da dormência, no caso de se trabalhar com estas sementes recém coletadas do campo. Por outro lado, sementes de $B$. plantaginea atingem valores máximos de germinação (84\%) aos quatorze meses após a colheita e em armazenamento em câmara fria e seca (15C e 30\% U.R.) (Oliveira \& Mastrocola, 1984). No campo, estas sementes podem permanecer viáveis no banco de sementes do solo por vários anos (Freitas, 1991).

É uma espécie cujos fluxos de emergência ocorrem tipicamente nos meses com temperaturas altas e com maiores quantidades de chuva, terminando o seu ciclo com o final do outono e a chegada do frio. O ciclo tende a ser reduzido nas condiçōes de clima frio, com as plantas vegetando até março ou abril, e antecipando o florescimento e frutificação para maio.

A B. plantaginea já foi cultivada no Brasil, em pequenas áreas, como forragem verde de verão, atingindo um rápido crescimento na primavera, alto valor nutritivo e produção abundante de sementes, podendo atingir $670 \mathrm{~kg}$ ha-1 (Whyte et al., 1977). 


\section{REFERÊNCIAS BIBLIOGRÁFICAS}

AHRENS, W.H. (Ed.) Herbicide handbook. 7. ed. Champaign, WSSA, 1994. $352 p$.

ALBAN, C.; BALDET, P.; DOUCE, R. Localization and characterization of two structurally different forms of acetyl-CoA carboxylase in young pea leaves, of which one is sensitive to aryloxyphenoxypropionate herbicides. Biochemical Journal n.300, p.557-565, 1994.

BLANCO, H.G. Catálogo das espécies de mato infestantes de áreas cultivadas no Brasil; gramíneas de ciclo anual. O Biológico, São Paulo, v.41, n.1, p.6-14, 1975.

BOLDT, L.D.; BARRETT, M. Effects of Diclofop and Haloxyfop on Lipid Synthesis in Corn (Zea mays) and Bean (Phaseolus vulgaris). Weed Science, v.39, p.143-148, 1991.

BORGEOIS, L.; KENKEL, N.C.; MORRISON, I.N. Characterization of crossresistance patterns in acetyl-CoA carboxylase inhibitor resistance wild oat (Avena fatua). Weed Science, v.45, p.750-755. 1997

BREZEANU, A.G.; DAVIS, D.G.; SHIMABUKURO, R.H. Ultraestructural effects and translocation of methyl 2-(4-(2,4-dichloro-phenoxy)phenoxy) propanoate in wheat (Triticum aestivum) and wild oat (Avena fatua). Canadian Journal of Botanic, v.54, p.2038-48, 1976.

BURTON, J.D.; GRONWALD, J.W.; KEITH, R.A.; SOMERS, D.A.; GENGENBACH, B.G.; WYSE, D.L. Kinetics of Inhibition of AcetylCoenzyme A Carboxylase by Sethoxydim and Haloxyfop. Pesticide Biochemistry and Physiology, v. 9, p.100-109, 1991. 
BURTON, J.D.; GRONWALD, J.W.; SOMERS, D.A.; BURLE, G.G.; WYSE, D.L. Inhibition of corn acetyl CoA carboxylase by cylclohexanodione and aryloxypropionate herbicides. Pesticide Biochemistry and Physiology, n. 34, p. 76-85, 1989.

BURTON, J.D.; GRONWALD, J.W.; SOMERS, D.A.; CONNELY, J.A.; GENGENBACH, B.G.; WYSE, D.L. Inhibition of Plant Acetyl-oenzyme A Carboxylase by the Herbicidez Sethoxydim and Haloxyfop. Biochemical Biophys. Res. Commum., v.148, p.1039-1044, 1987.

CHRISTOFFOLETI, P.J.; CORTEZ, M.G. e VICTORIA FILHO, R. Resistance of alexanderweed (Brachiaria plantaginea) to ACCase inhibitor herbicides in soybean from Paraná State - Brazil. In: MEETING OF THE WEED SCIENCE SOCIETY OF AMERICA, CHICAGO, 1998. Abstracts. Chicago: WSSA, 1998. p. 65.

CHRISTOFFOLETI, P.J.; VICTORIA FILHO, R.; SILVA, C.B. Resistência de plantas daninhas aos herbicidas. Planta Daninha, v.12, n.1, p.1320.,1994.

COBLE, H.D. Weed management tools and their impact on the agro-ecosystem. Proc. 2nd Int. Weed Control Congress, Copenhagen, p. 1143-1146. 1996.

COLE, D.J. Detoxification and activation of agrochemicals in plants. Pesticide Science, v.42, p.209-222, 1994.

CORBETT, J.R.; WRIGHT, D.; BAILLIE, A.C. The biochemical mode of action of pesticides. Academic Press, London. 1984. 
COUPLAND, D. The role of compartmentation of herbicides and their metabolites in resistance mechanisms. In: CASELEY, J.; C. CUSSANS, G.W.; ATKIN, R.K. eds Herbicides resistance in weeds and crops. Butterworth-Heinemann Ltd., Oxford. p-263-278. 1991.

CUSSANS, G.W. Which weed management strategies are appropriate? Proc. 2nd Int. Weed Control Congress, Copenhagen, p.1159-1166. 1996.

DE PRADO, R.; DOMINGUEZ, C.; TENA, M. Triazine resistance in biotypes of Solanum nigrum and four Amaranthus species found in Spain. Weed Research. n.33, p.17-24, 1993a.

DE PRADO, R.; LOPEZ, N. Resistência a herbicidas: Detección en campo y laboratorio. In: I CURSO SOBRE EL USO DE HERBICIDAS EN LA AGRICULTURA MODERNA. Cordoba/Espanha, 1999. Resumos. ETSIAM/UCO, 1999. p. 52.

DE PRADO, R.; MENÉNDEZ, J.; TENA, M. Response to substituted ureas, triazines and chloroacetanilides in a biotype of Alopecurus myossuroides resistant to chlorotoluron. In: BRIGHTON CROP PROTECTION CONFERENCE - WEEDS. p. 1065-1070, 1991.

DE PRADO, R.; MENENDEZ, J.L. Cross-resistance and herbicide metabolism in Alopecurus myosuroides Huds. In: Regulation of Enzymatic System Detoxifying Xenobiotics in Plants (HATZIOS, K. K., ed.). Kluwer Academic Publisher, p. 351-366. 1997.

DEVINE, M.; HALL, J.C.; ROMANO, M.L.; MARLES, M.A.S.; THOMPSON, L.W.; SHIMABULURO, R.H. Diclofop and fenoxaprop resistance in wild oat is associated with an altered effect on the plasma membrane electrogenic potential. Pesticide Biochemistry and Physiology, v.45, p.167-177, 1993b. 
DEVINE, M.D. Mechanisms of resistance to acetyl coenzyme A carboxylase inhibitors: a review. Pesticide Science, v.51, p.259-264, 1997.

DEVINE, M.D. The biochemical basis of herbicide resistance in wild oat. In: Wild Oats in World Agriculture. In: 4TH INT. OAT CONF. (Barr, A. R., Medd, R.W., eds.). Adelaide, Australia, Proceedings. p. 41-44. 1992a.

DEVINE, M.D.; McISAAC, S.A.; ROMANO, M.L.; HALL, J.C. Investigation of the Mechanism of Diclofop Resistance in Two Biotypes of Avena Fatua.. Pesticide Biochemistry and Physiology, v.42, p.88-96, $1992 \mathrm{~b}$.

DEVINE, M.D.; SHIMABUKURO, R.H. Acetyl coenzyme A carboxylase inhibiting herbicides. In: POWLES, S.B. ; HOLTUM, J. A.M. eds Herbicide Resistance in Plants: Biology and Biochemistry, p.141-169. CRC Press, London. 1994.

DITOMASO, J.M.; STOWE, A.E.; BROWN, P.H. Inhibition of Lipid Synthesis by Diclofop-Methyl is Age Dependent in Roots of Oat and Corn. Pesticide Biochemistry and Physiology, v.45, p.210-219, 1993.

DUKE, S.O. Modes of action of herbicides used in cotton. In: McWHORTER, C.G.; ABERNATHY, J.L, eds. Weeds of Cotton: Characterization and Control The Cotton Foundation, Memphis, TN, p. 403-437. 1992.

DUKE, S.O.; KENYON, W. H. Polyciclic alkanoic acids. In: KEARNEY, P.C.; KAUFMAN, D.D. eds. Herbicides: Chemistry, Degradation, and Mode of Action Marcel Dekker, New York, p. 71-116. 1988. 
EBEL, J.; HAHLBROCK, K. Enzymes of flavone and flavonol glycoside biosynthesis. Coordinated and selective induction in cell-suspension cultures of Petroselinum hortense. European Journal of Biochemistry, v. 75, p. 201-209, 1977.

EGLI, M.A.; GENGENBACH, B.; GRONWALD, J.W.; SOMERS, D.A.; WISE, D.L. Characterization of maize acetyl-Coenzime A carboxylase. Plant Physiology, n.101, p.499-506, 1993.

F.A.O. Production Yearbook. Vol. 51. 1997.

GARCÍA TORRES, L.; FERNÁNDEZ-QUINTANILLA, C. Fundamentos sobre malas hierbas $\mathrm{g}$ herbicidas. Mundi-Prensa. Madrid. 1991. 348p.

GAZZIERO, D.L.P; BRIGHENTI, A.M.; MACIEL, C.D.G.; CHRISTOFFOLETI, P.J.; ADEGAS, F.S. Resisitência der amendoim-bravo aos herbicidas inibidores da enzima ALS. Planta Daninha, v.16, p. 117-126, 1998.

GAZZIERO, D.L.P; CHRISTOFFOLETI, P.J.; MACIEL, C.D.M.; SCARAMUZA JÚNIOR., J.R. Resistência de biótipos de Brachiaria plantaginea aos herbicidas inibidores da ACCase aplicados em soja. In: CONGRESSO BRASILEIRO DA CIÊNCIA DAS PLANTAS DANINHAS. 21, Caxambu/MG,1997. Resumos. Caxambu:SBCPD, 1997. p.88.

GILLET, M. Las gramineas forrajeras: descripción, funcionamento, aplicaciones al cultivo de la hierba. Zaragoza, Acribia, 1984. 355p.

GRESSEL, J.; SEGEL, L.A. Herbicide rotations and mixtures: effective strategies to delay resistance. In: GREEN, M.B.; LeBARON, H.L.; MOBERG, W.R. Managing Resistance to Agrochemicals: from Fundamental Research to Practical Strategies. American Chemical Society. Washington, 1990. p.430-458. 
GRESSEL, J.L.; SEGEL, L.A. Interrelating factors controlling the rate of apperance of resistance: the outlook for the future. In: LeBARON, H. M.; GRESSEL, J.L., Herbicide Resistance in Plants John Wiley \& Sons, New York, p.325-347. 1982.

GRIGNON, C.; SENTENAC, H. pH and ionic conditions in the apoplast. Annual Review of Plant Physiology and Plant Molecular Biology, v.42, p. 103-128, 1991.

GRONWALD, J.W. Lipid biosynthesis inhibitors. Weed Science, v.39, p.435449, 1991.

GRONWALD, J.W. Lipid biosynthesis inhibitors. Weed Science, v. 39, p. 435-449, 1991.

GRONWALD, J.W. Resistance to photosystem II inhibiting herbicides. In: POWLES, S.B. ; HOLTUM, J. A.M. eds Herbicide Resistance in Plants: Biology and Biochemistry, p. 27-60. 1994a.

GRONWALD, J.W.; EBERLEIN, C.V.; BETTS, K.J.; BAERG, R.J.; EHLKE, N.J.; WYSE, D.L. . Mechanism of diclofop resistance in na Italian ryegrass (Lolium multiflorum Lam.) biotype. Pesticide Biochemistry and Physiology, n. 44, p.126-139, 1992.

GUNSOLUS, J.L. Herbicide resistant weeds. Extension Publication. Minessota Extension Service. 1993. 468p.

HALL, L.M.; TARDIFF, F.; POWLES, S.B. Mechanism of cross and multiple resistance in Alopecurus mysuroides and Lolium rigidum. Phytoprotecion, v. 73, p.17-23, 1994. 
HARWOOD, J.L. Fatty acid metabolism. Annu. Rev. Plant Physiol. Plant Mol. Biol., v.39, p.101-138, 1988.

HÄUSLER, R.E.; HOLTUM, J.A.M.; POWLES, S.B. Cross-resistance to herbicides in annual ryegrass (Lolium rigidum). IV. Correlation between membrane effects and resistance to graminicides. Plant physiology, n.97, p.1035-1043, 1991

HEAP, I.M. The ocurrence of herbicide-resistant weeds worlwide. Pesticide Science, v.51, p.235-243, 1997.

HEAP, I.M.; KNIGHT, R. Variation in Cross-Resistance among Populations of Annual Ryegrass (Lolium rigidum) Resistant to Diclofop-Methyl. Australian Journal of Agricultural Reseach. v.41, p.21-128, 1990.

HEAP, I.M.; KNIGHT, R.A population of ryegrass tolerant to the herbicide diclofop-methyl. Journal Austral. Ins. Agric. Sci., v.48, p.156-157, 1982.

HEAP, I.M.; MORRISON, I.N. Resistance to aryloxyphenoxypropionate and cyclohexanodione herbicides (Group 1) herbicides in Green foxtail (Setaria viridis L. Beav.). WSSA Abstracts. Denver, Colorado. 55: p.164. 1982.

HEAP, I.M.; MURRAY, B.G.; LOEPPKY, H.A.; MORRISON, I.N. Resistance to aryloxyphenoxypropionate and cyclohexanodione herbicides in wild oat (Avena fatua). Weed Science, v.41, p.232-238, 1993.

HERBERT, D.; COLE, D.J.; PALLETT, K.E.; HARWOOD, J.L. Susceptibilities of different tests systems from mays (Zea mays), Poa annua and Festuca rubra to herbicides that inhibit the enzyme acetyl-coenzime A carboxilase. Pesticide Biochemistry and Physiology, v.55, p.129-139. 1996. 
HESS, F.D. Herbicide absorption and translocation and their relationship to plant tolerance and susceptibility. In: DUKE, S.O. ed. Weed Phsyiology, vol. II: Herbicide Physiology CRC Press, Boca Raton. p.192-214., 1985.

HOLT, J. Fitness and ecological adaptability of herbicide resistant biotypes. In: GREEN, M.B.; LeBARON, H.L.; MOBERG, W.K. Managing Resistance to Agrochemicls: from Fundamental Research to Practical Strategies. American Chemical Society. Washington, p.419-429. 1995.

HOLT, J.S.; LeBARON, H.M. Significance and distribution of herbicide resistance. Weed Technology, n.4, p.141-49, 1990.

HOLTUM, J. A.M. Herbicide resistant wild oats in Australia. In: Wild Oats in World Agriculture, Proc. 4th Int. Oat Conf. (Barr, A. R., Medd, R. W., eds.). Adelaide, Australia, p. 45-48. 1992.

HOLTUM, J.A.M.; HÄUSLER, R.E.; DEVINE, M.D.; POWLES, S.B. Recovery of transmembrane potentials in plants resistant to aryloxyphenoxypropanoate herbicides: A phenomenon awaiting explantion. Weed Science, n.42, p.293-301, 1994.

HOLTUM, J.A.M.; MATTHEWS, J.M.; HÄUSLER, R.E.; LILJEGREN, D.R.; POWLES, S.B. Cross-resistance to herbicides in annual ryegrass (Lolium rigidum).III. On the mechanism of resistance to diclofop-methyl. Plant Physiology, n.97, p.1026-1034, 1991.

HOPPE, H.H. Differential Effect of Diclofop-Mehtyl on Fatty Acid Biosynthesis in Leaves of Sensitive and Tolerant Plant Species. Pesticide Biochemistry and Physiology., v. 23, p. 297-308, 1985. 
HOPPE, H.H. Fatty acid biosynthesis - a target site of herbicide action. In: BÖGER, P.; SANDMANN, G., eds Target sites of herbicide action, CRC Press, Boca Ration. p.65-83, 1989.

HOSAKA, H.; TAKAGI, M. Biochemical effects of sethoxydim in excised root tips of corn (Zea mays). Weed Science, v.35, p.612-618, 1989.

ISHIHARA, K.; KOSAKA, H.; KUBOTA, M.; KAMIMURA, H.; TAKAKUSA, M.; YASUDA, Y. Effects of sethoxydim on the metabolism of excised root tips of corn. In: GREENHALGH, R. ; ROBERTS, T. (eds.) Pesticide Chemistry and Techonolgy, Blackwell Scientific, Palo Alto, CA. 1987, p.187-190.

JÄGER, G. Herbicides. In: BÜCHEL, K. H. Chemistry of pesticides John Wiley \& Sons, New York, p.322-392. 1983.

JEFFCOAT, B.; HARRIES, W.N. Selectivity and mode of action of ethyl ( \pm )-2Nbenzoyl-3, 4-dichloroanilino) propionate in the control of Avena species in wheat. Pesticide Science, v. 4, p.891, 1973.

JUTSUM, A. R.; GRAHAM, J. C. Managing weed resistance: the role of the agrochemical industry. Proc. Brighton Crop Prot. Con. Weeds, p. 557 566. 1995.

KAFIZ, B.; CAUSSANEL, J.P.; SCALLA, R.; GAILLARDON, P. Interaction Between Diclofop-methyl and 2,4-D in Wild Oat (Avena fatua L.) and Cultivated Oat (Avena sativa L.) and Fate of Diclofop-Methyl in Cultivated Oat. Weed Research, v. 29, p. 299-305, 1989.

KISSMANN, K.G. Plantas infestantes e nocivas. 1ed. São Paulo, SP: BASF Brasileira S.A., 1991. 603p. 
KOBEK, K.; FOCKE, M.; LICHTENTHALER, H. K. Fatty acid biosynthesis and acetyl-CoA carboxylase is a target of diclofop, fenoxaprop and other ariloxyphenoxy-propionic acid herbicides. 2. Naturforsch., v.43, p.47-54, 1987.

KOBEK, K.; FOCKE, M.; LICHTENTHALER, H. K.; RETZLAFF, G.; WÜRZER, B. Inhibition of fatty acid biosynthesis in isolated chloroplast by cycloxidim and other cyclohexane-1,3-diones. Physiology Plantarum, v.72, p.492498, 1988.

KONISHI, T.; SASAKI, Y. Compartmentalization of two forms of acetyl-CoA carboxylase in plants and the origin of their tolerance toward herbicides. Proc. Natl. Acad. Sci., USA, v.91, p.3598-3601, 1994.

LADLIE, J.S. Guide to herbicide injury symptoms in soybeans with "look-alike" symptoms. Hollamdale: Agri-Growth Research, 1991, 86 p.

LeBARON, H.M. Herbicide resitance in crops and weeds and its management. In: TROPICAL WEED SCIENCE CONFERENCE, 3, Kuala Lumpur/Malasia, 1992. Proceedings. p.23-24. 1992.

LeBARON, H.M.; GRESSEL, J. Herbicide resistance in plants. New York: John Wiley \& Sons. 1982. 441p.

LICHTENTHALER, H.K.; KOBEK, K. Inhibition by sethoxydim of pigment accumulation and fatty acid biosynthesis in chloroplast of Avena seedlings. Z. Naturforsch, v.42, p.1275-1279, 1987.

LORENZI, H. Plantas daninhas do Brasil: terrestres, aquáticas, parasitas, tóxicas e medicinais. 2ed. Nova Odessa, SP: Editora Plantarum, 1991. 440p. 
MANSOOJI, ${ }^{a}$ M.; HOLTUM, J. ${ }^{a}$ M.; BOUTSALIS,P.; MATTHEWS, J.M.; POWLRS, S.B. Resistance to aryloxyfhenoxypropionate herbicides in two wild oat species (Avena fatua and Avena sterilis). Weed Science, v.40, p.599-605, 1992.

MARLES, M.A.S.; DEVINE, M.D.; HALL, J.C. Herbicide resistance in Setaria viridis conferred by a less sensitive form of acetyl coenzyme A carbozylase. Pesticide Biochemistry and Physiology, v. 46, p.7-14, 1993.

MARLES, M.S.A.; DEVINE, M.D.; HALL, J.C. Herbicide resistance in Setaria viridis conferred by a less sensitive form of acetyl coenzyme A carboxylase. Pesticide Biochemistry and Physiology, v.46, p.7-14, 1993.

MARSHALL G.; KIRKWOOD, R.C.; LEACH, G.E. Comparative studies on graminicide-resistant and susceptible biotypes of Eleusine indica. Weed Research, v. 34, n.3, p.177-185, 1994.

MATHEWS, J.M.; HOLTUM, J.A.M.; LILJEGREN, D.R.; FURNESS, B.; POWLES, S.B. Cross-resistance to herbicides in annual ryegrass (Lolium rigidum). I. Properties of the target enzymes acetyl-coenzyme A carboxylase and acetatolactate synthase. Plant Physiology, v.94, p.1180-1186, 1990.

MAXWELL, B.D.; MORTIMER, M. Selection for herbicide resistance. In: Herbicide Resistance in Plants: Biology and Biochemistry (Powles, S. B., y Holtum, J. A. M., eds.). CRC Press, Boca Raton, p.1-25. 1994.

MENENDEZ J.; JORRIN, J.; TABERNER, A.; DE PRADO, R. Penetration, manslocation and metabolization of diclofop-methyl in chlorotoluronresistant and susceptible biotypes of Alopecurus myosuroides. Proceedings of the Brighton Crop Protection Conference-Weeds, Brighton, England 1993, p.213-220. 
MENENDEZ, J. Mecanismos de resistência a herbicidas en biotipos de Alopecurus myosuroides huds. Cordoba, 1997. 246p. Tese (Doutorado) Escuela Técnica de Ingenieros Agrónomos y de Montes - Universdiad de Cordoba/Espanha.

MENENDEZ, J.; DE PRADO, J.L.; DE PRADO, R. Diclofop metabolism in resistant biotypes of Lolium rigidum Gaudin. Proceedings of the International Symposium on Weed and Crop Resistance to Herbicide, Cordoba, Spain, 1996, p.97-98.

MENENDEZ, J.; DE PRADO, R. Diclofop-methyl cross-resistance in a chlorotoluron resistant biotype of Alopecurus myossuroides. Pesticide Biochemistry and Physiology, v. 56, p.123-133, 1996.

MENENDEZ, J.; DE PRADO, R. La resistencia de las malas hierbas a los herbicidas. Phytoma, 94, 43-50, 1998.

MONQUEIRO, P.A. Biologia, manejo e caracterizaçāo bioquimica e genética de biotipos de plantas daninhas resistentes aos herbicidas inibidores da acetolato sintase (ALS). ESALQ-Piracicaba, SP, 1999. 94p. (Dissertaçāo Mestrado) - ESALQ - Universidade de Sāo Paulo

MOSS, S.R. Herbicide cross-resistance in slender foxtail (Alopecurus myosuroides). Weed Science, v. 38, p. 492-496, 1990.

MOSS, S.R.; CUSSANS, G.W. The development of herbicide-resistant populations of Alopecurus myosuroides (black-grass) in England. In: CASELEY, J.C.; CUSSANS, G.W.; ATKIN, R.K., eds, Herbicide resistance in weeds and crops, Butterworth-Heinemann, Oxford. p.45-55, 1991. 
NEALE, M.C.; SUTTON, A. European view of horticultural crop protection. In:

D. TYSON, ed Crop protection: Crisis for UK Horticulture? British Crop Protection Council, Farnham. p.79-88, 1993.

NIKOLAU, B. J.; Y HAWKE, J. C. Purification and characterization of maize leaf acetyl-coenzime A carboxylase. Arch. Biochem. Biophys., v.228, p.86-96, 1984.

O'SULLIVAN, P.A. Diclofop. In: DONALD, W.W. Systems of weed control in wheat in North America, WSSA, Champaign, p.321-345, 1990.

OLIVEIRA, P.R.P. de; MASTROCOLA, M.A. Longevidade das sementes de gramineas forrageiras tropicais (1). Boletim da Indústria Animal, n.41, p. 203-211, 1984.

PONCHIO, J.A.R. Resistência de Bidens pilosa aos herbicidas inibidores da enzima acetolactato sintase. ESALQ-Piracicaba, 1997. 120p. (Tese Doutorado)- ESALQ - Universidade de São Paulo.

PONCHIO, J.A.R.; CHRISTOFFOLETI, P.J.; VICTORIA FILHO, R. ALS enxyme assay from Bidens pilosa biotypes of the Brazilian soybean areas to determine the sensitivety to imidazolinone and sulfonylurea herbicides. In: MEETING OF THE WEED SCIENCE SOCIETY OF AMERICA, 36, Nortfolk, 1996. Proceedings. p.79.

POST-BEITTENMILLER D.; JAWARSKI, J.G.; OHLROGGE, J.G. In vivo pools of free and acylated-acyl carrier proteins in spinach: Evidence for sites of regulation of fatty acid biosynthesis. Journal of Biological Chemistry, v. 266, p.1858-1865, 1991. 
POWLES, S.B.; PRESTON, C. Herbicide cross resistance and multiple resistance in plants. Departament of crop protection. Waite Agricultural Research Institute. University of Adelaide. South Australia, 1995. 34 p.

POWLES, S.B; HOLTUM, J.A.M. Herbicide resistance in plants: Biology and biochemistry. Boca Raton: Lewis, 1994, 353 p.

PRESTON, C. Resistance to photosystem I disrupting herbicides. In: Herbicide Resistance in Plants (Powles, S. B., y Holtum, J. A. M., eds.). Lewis Publishers, Boca Raton, FL, p. 61-82. 1994.

RATTERMAN, D.M.; BALKE, N.E. 1989. Diclofop-methyl increases the proton permeability of isolated oat-root tonoplast. Plant Physiology, v. 91, p.756765, 1989.

RENDINA, A.R.; CRAIG-KENNARD, A.C.; BEAUDOIN, J.D.; BREEN, M.K. Inhibition of Acetyl-Coenzyme A Carboxylase by Two Classes of GrassSelective Herbicides. J. Agric. Food Chem. v.38, p.1282-1287, 1990.

RODRIGUES, B.N. e ALMEIDA, F.S. Guia de herbicidas. 4. ed. Londrina: IAPAR, 1998, 648p.

RUBIM, B. Herbicide resistant weeds. The inevitable phenomenon: mechanisms, distribution and significance. Zeitschrift fur Pflanzenkrankheiten und Pflanzenshutz, v.15, p.17-32, 1996.

RUBIM, B. Herbicide resistance in weeds and crops, progress and prospects. In: CASELEY, J.C.; CUSSANS, G.W.; ATKIN, R.K.. Herbicide Resistance in Weeds and Crops. Butterworth-Heinemann Ed. Oxford, 1991. pp. 387414. 
SAARI, L.L.; COTTEMAN, J.C.; THILL, D.C.. Resistance to acetolactate synthase inhibiting herbicides. In: Herbicide Resistance in Plants (Powles, S. B., y Holtum, J.A.M., CRC Press, Boca Raton, pp. 83-140. 1994

SASAKI, Y.; HAKAMADA, K.; SUAMA, Y.; NAGANO, Y.; FURUSAWA, I.; MATSUNO, R. Chloroplast-encoded protein as a subunit of acetyl-CoA carboxylase in pea plant.. J. Biol. Chem., v.268, p.25118-25123, 1993.

SASAKI, Y.; KONISHI, T.; NAGANO, Y. The compartmentation of acetylcoenzyme A carboxylase in plants. Plant Physiology, v.108, p. 445449, 1995.

SAWICKI, R.M. Definition, detection and documentation of insecticide resistance. In: FORD, M.G.; HOLLMAN, D.W.; KHAMBAY, B,. SAWICKI, R.M. Combating Resistance to Xenobiotics: Biological and Chemical Approaches. Ellis Horwood, Ed. Chichester, 1987. p.105-117.

SECOR, J.; CSÉKE, C.; OWEN, W.J. The discovery of the selective inhibition of acetyl coenzyme A carboxylase activity by two classes of graminicides. Proceedings of the Brighton Crop Protection Conference-Weeds, Brighton, England, v.1, p.145-154. 1989.

SENTENAC H.; GRIGNON, C. Effect of $\mathrm{H}^{+}$excretion on the surface $\mathrm{pH}$ of corn cells evaluated by using weak acid influx as a $\mathrm{pH}$ proble. Plant Physiology, v.84, p.1367-1372, 1987.

SHANER, D.L. Herbicide resistance in North America: History, circunstances of development and current situation. In: De PRADO, R.; JRRIN, J.; GARCIATORRES, L. eds. Weed and crop resistance to herbicides, Kluwer, Dordrecht. p.29-38. 1997. 
SHANER, D.L.; SIMCOX, P. D.; ROBSON, P.A. et al. AC - 222,293 translocation and metabolic selectivity. In: PROC. BRITISH PLANT PROT. CON. p. 333-339, 1983.

SHERMAN, T.D.; VAUGHN, K.C.; DUKE, S.O. Mechanism of action and resistance to herbicides. In: DUKE, S.O. (Ed.) Herbicides Resistant Crops. Boca Raton: CRC press, 1996. p.14-28.

SHIMABUKURO, R.H. ; HOFFER, B.L.. Effect of Diclofop on the Membrane Potentials of Herbicide-Resistent and Susceptible Annual Ryegrass Root Tips. Plant Physiology, v.98, p.1415-1422, 1992.

SHIMABUKURO, R.H. Selectivity and Mode of Action of the Postemergence Herbicide Diclofop-Methyl. Plant Growth Regul. Soc. Am. Q., v.18, p.3754, 1990.

SHIMABUKURO, R.H.; HOFFER, B.L. Diclofop action: physiological evidence for reversible binding to a receptor-like molecule. Weed Sciences Society of America. Abstracts 182. 1988.

SHIMABUKURO, R.H.; HOFFER, B.L. Perturbation of transmembrane proton gradient and inhibition of fatty acid metabolism: Their roles in the mechanism of action of ficlofop-methyl. Weed Science Society of America. Abstract no. 176. 1990.

SHIMABUKURO, R.H.; HOFFER, B.L. Perturbation of the transmembrane proton gradient and resistance to AOPP herbicides. In: De PRADO, R.; JORRIN, J.; GARCIA-TORRES, L. eds. Weed and crop resistance to herbicides, Kluwer, Dordrecht. p.71-80. 1997. 
SHIMABUKURO, R.H.; HOFFER, B.L.. Metabolism of diclofop-methyl in susceptible and resistant biotypes of Lolium rigidum. Pesticide Biochemistry and Physiology, v.39, p.251-258, 1991

SHIMABUKURO, R.H.; WALSH, W.C.; HOERAUF, R.A. Metabolism and selectivity of diclofop-methyl in wild oat and wheat. J. Agric. Food Chem., v.27, p.615-623, 1979.

SILVERTOWN, J.W. Introduction to plant population ecology. New York: Longman. 2.ed. 1987. 220p.

SINDAG - Sindicato da indústrias de defensivos agricolas - Boletim 99, divulgado por e-mail.

SMEDA, R.J.; BARENTINE, W.L.; SNIPES, C.E. Johnsongrass (Sorghum halepense (L.) Pers.) resistence to postemergence grass herbicides. Weed Science Society of America. Abstract no. 53. 1993.

STOLTENBERG, D.E.; WIEDERHOLT, R.J. Giant foxtail (Setaria faberi Herm.) resistance to acetylCoA carbozylase inhibitors. Weed Science Society of America. Abstract no. 183. 1993.

STUMPF, P.K. The biosynthesis of saturated fatty acids. In: STUMPF, P. K.; CONN, E.E. eds The biochemistry of plants. Vol. 9: Lipids: Structure and Funcytion, v.9, p.121-157. Academy Press, New York. 1987.

TARDIF, F.J.; POWLES, S.B. Herbicide multiple-resistance in a Lolium rigidum biotype is endowed by multiple mechanisms: isolation of a subset with resistant acetyl-CoA carboxylase. Physiologia Plantarum, v.91, p.488494, 1994. 
THAI, K.M., JANA, S.; NAYLOR, J.M. Variability for response to herbicides in wild oat (Avena fatua) populations. Weed Science, v.33, p.829-835. 1985.

VIDAL, R.A.; FLECK, N.G. Three weed species with confirmed resistance to herbicides in Brazil. In: MEETING OF THE WEED SCIENCE OF AMERICA, 1997. Abstracts. p. 100.

WAKIL, S.J.; STOOPS, J.K.; JOSHI, V.C. Fatty acid synthesis and its regulation. Annu. Rev. Biochem., v.52, p.537-579, 1983.

WALKER, K.A.; RIDLEY, S.M.; LEWIS, T. \& HARWOOD, J.L. Action of Aryloxyphenoxy Carboxylic Acids on Lipid Metabolism. Weed Science. v.4, p. $71-84,1989$.

WALKER, K.A.; RIDLEY, S.M.; LEWIS, T.; HARWOOD, J.L. Fluazifop, a grass selective herbicide which inhibits acetyl-CoA carboxylase in sensitive plants species. Biochemistry Journal, v.254, p.307-310, 1988.

WEED SCIENCE SOCIETY OF AMERICA. Herbicide handbook, $6^{\text {th }}$ Edition. Champaign :WSSA. 1989. 515p.

WHITEHEAD, C.W.; SWITZER, C.M. The differencial response of strains of wild carrot to 2,4-D and related herbicides. Canadian Journal of Plant Science. v. 43, p.255-262, 1962.

WHYTE, R.O.; MOIR, T.R.G.; COOPER, J.P. Las gramineas en la agricultura. Roma, FAO, 1975. 464p.

WOODBURN, A.T. Global and regional market estimates. In: Allan Woodburn Associates, Agrochemicals-Executive Review, 6th edition, , Edinburgh. p.12-13. 1995. 
WRIGHT, J.P.; SHIMABUKURO, R.H. Effects of diclofop and diclofop-methyl on the membrane potentials of wheat and oat coleoptiles. Plant Physiology, v. 85, p.188-193, 1987.

WSSA. N.E. HUMBURG, S.R. COLBY, R.G. LYM, E.R. HILL, W.J. MCAVOY, L.M. KITCHEN Y R. PRASAD, eds., Herbicide Handbook of the Weed Science Society of America, $6^{\text {th }}$ edition, Weed Science Society of America, Champaign, Illinois. 1989. 301p.

ZADOKS, J.C.. The cost of the change in plant protection. Journal Plant. Protection In the Tropics, v.9, n.2, p.151-159. 1992. 


\section{CAPÍTULO III}

\section{RESISTÊNCIA CRUZADA EM BIOTIPOS DE Brachiaria plantaginea (Link) Hitchc. A HERBICIDAS INIBIDORES DA ACETIL COENZIMA A CARBOXILASE (ACCase)}

RESUMO: Dois biotipos (A e B) de B. plantaginea resistentes apresentaram resistência cruzada a vários herbicidas inibidores da ACCase. As taxas de resistência que inibiram $50 \%\left(\mathrm{GR}_{50}\right)$ do controle ou da produção de fitomassa foram determinadas para seis ariloxifenoxipropionatos (APP) (propaquizafop, diclofop, haloxyfop, quizalofop, fluazifop e fenoxaprop), e quatro ciclohexanodionas (CHD) (sethoxydim, clethodim e butroxydim). Ambos biotipos, apresentaram para a maioria dos herbicidas testados, valores de GR50 acima das doses de campo recomendadas, no entanto os valores taxas de resistência máxima e minima obtidas com os biotipos e herbicida testados foram aproximadamente equivalentes. Os biotipos apresentaram os maiores valores de $\mathrm{GR}_{50}$ para o sethoxydim, tanto na avaliação de controle como na de fitomassa recém-colhida, sendo que os menores velores de $G_{50}$, para ambas variáveis e biotipos, foram observado para o herbicida clethodim. Com relação às taxas de resistência, os biotipos $\mathrm{A}$ e $\mathrm{B}$ apresentaram niveis variáveis para os herbicidas testados, sendo que a maior taxa de resistencia obtida para ambos biotipos, tanto para controle quanto para produção de fitomassa, foi para o herbicida sethoxydim (biotipo A: controle $=783,5$ e fitomassa $=>1600$; $\mathrm{e}$ biotipo $\mathrm{B}$ : controle $=872,5$ e fitomassa $=1122,8)$. As menores taxas de 
resistência obtidas para o biotipo $A$, foram para os herbicidas clethodim (controle $=12,0$ ) e propaquizafop (fitomassa $=10,5$ ). As menores taxas de resistência obtidas para o biotipo $B$, foram para os herbicidas clethodim (controle $=12,0$ ) e propaquizafop (fitomassa $=2,1$ ).

Palavras-chave: resistência a herbicidas, resistência cruzada, Brachiaria plantaginea

\section{SUMMARY}

\section{SUSCEPTIBILITY AND CROSS RESISTANCE RATE OF Brachiaria} plantaginea (Link) Hitchc. BIOTYPES TO ACCase INHIBITOR HERBICIDES

SUMMARY: Two byotipes (A and B) of B. plantaginea showed cross resistance to several ACCase inhibitor herbicides. The rate of resistance that inhibited $50 \%\left(G_{50}\right)$ of control or the biomass production were determined to six aryloxyphenoxypropinates (APP) (propaquizafop, diclofop, haloxyfop, quizalofop, fluazifop e fenoxaprop), and three cyclohexanodiones (CHD) (sethoxydim, clethodim e butroxydim). Both biotypes, presented to most of the herbicides tested, values of $\mathrm{GR}_{50}$ higher than the recommended field rate, however the rates of maximum and minimum resistance obtained with the biotypes and herbicides tested were approximately equivalent. The biotypes presented values of $\mathrm{GR}_{50}$ for sethoxydim, for percent control and biomass, however for clethodim it was obtained the lower values. The biotypes A and B presented variable levels of resistance to the herbicides tested, when both parameters, percent control and biomass were analyzed (biotype A: control = 783.5 and biomass $=>1600$; and biotype $\mathrm{B}$ : control $=872.5$ and biomass $=$ 122.8). The lower rates of resistance obtained biotype $A$, were for the herbicides clethodim (control $=12.0$ ) and propaquizafop (biomass $=10.5$ ).

Key words: herbicide resistance, cross-resistance, Brachiaria plantaginea 


\section{INTRODUÇĀO}

Em geral, as áreas produtoras de soja no Brasil, têm sido expostas a maiores quantidades e variedades de herbicidas que as áreas de produçāo para outras culturas (Capitulo 2 - Tabela 2). A infestaçāo de $B$. plantaginea na cultura de soja, cujo controle tem sido realizado intensivamente com o uso de herbicidas, determinou o aparecimento de áreas onde caracterizou-se a ocorrência de biotipos resistentes a herbicidas (Vidal, 1996; Gazziero et al., 1997; Christoffoleti et al., 1998 e Cortez et al., 1999). A resistência de biotipos de $B$. plantaginea tem sido verificada em um ou mais representantes dos herbicidas dos grupos quimicos APP e CHD, evidenciando a ocorrência de resistência cruzada.

Dentre as espécies que apresentam resistência a herbicidas, é de especial interesse a Brachiaria plantaginea, visto que é o primeiro caso de graminea no Brasil na qual detectou-se a resistência ao grupo de herbicidas ariloxifenoxipropionatos e ciclohexanodionas.

Biotipos de $B$. plantaginea resistentes a herbicidas inibidores da ACCase têm sido diagnosticados no município de Guarapuava-PR, regiāo sudoeste do Estado do Paraná, em propriedades onde os APP e CHD vêm sendo utilizados durante vários anos (Gazziero et al., 1997; Christoffoleti et al., 1998; Cortez et al., 1999). No entanto, a área total afetada ainda nāo foi levantada.

Algumas caracteristicas biológicas desta espécie de planta daninha favorecem o desenvolvimento de biotipos resistentes a herbicidas. Dentre estas caracteristicas destacam-se: ampla distribuiçāo em áreas cultivadas; alta capacidade reprodutiva; alta produção de sementes; rápida reposiçāo do banco de sementes; reproduçāo alógama e plasticidade genotípica e fenotipica (Seldulsky, 1978). 


\subsection{Metodologia para comprovação da resistência de plantas daninhas a herbicidas}

Desde a identificação do primeiro biotipo resistente da planta daninha Senecio vulgaris, nos Estados Unidos da América do Norte (Ryan, 1970), tem crescido intensivamente o número de casos relatados (Heap, 1998).

Na Figura 1 é apresentado um fluxograma com os passos que devem ser considerados para a determinação e caracterização de uma planta daninha resistente.

\subsubsection{Determinação em campo:}

O fato de determinadas populaçōes de plantas daninhas escaparem ao controle dos herbicidas normalmente utilizados não implica necessariamente que tenham desenvolvido mecanismos de resistência, já que a efetividade dos herbicidas depende de muitos fatores externos que podem diminuir a eficácia dos tratamentos em um dado momento.

As áreas que possivelmente apresentem biotipos de plantas daninhas resistentes de plantas daninhas poderiam ser caracterizadas com os seguintes aspectos:

a) Campos onde determinadas populaçōes de plantas daninhas bem controladas no passado e que no momento escapam ao controle do herbicida normalmente utilizado, apesar de outras populações da mesma planta daninha serem controladas no mesmo campo, com o mesmo herbicida;

b) Campos nos quais as falhas de controle não podem ser atribuídas:1) ao fator herbicida: recomendação errada do herbicida; doses e momento de aplicação; falhas na tecnologia de aplicação; não utilização dos adjuvantes 


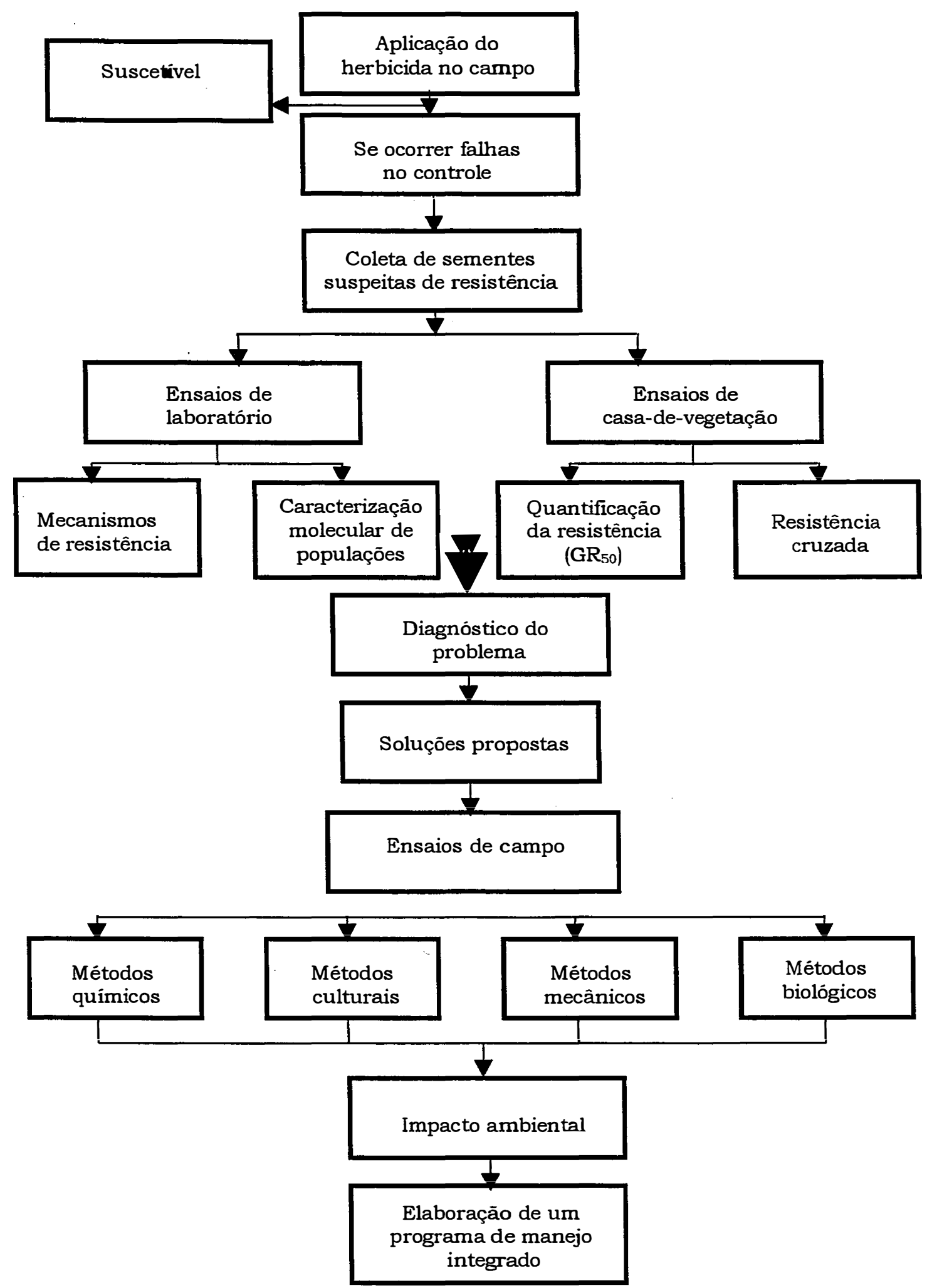

Figura 1. Fluxograma de objetivos propostos para a caracterização de biotipos de plantas daninhas resistentes a herbicidas (Adaptado de: De Prado \& Lopez, 1999). 
recomendados; uso de misturas seqüenciais ou de tanque com efeito antagônico, ou então, 2) ao fator solo: umidade e $\mathrm{pH}$; presença de alto teor de matéria orgânica; presença de microflora com aptidão degradativa para esse herbicida;

c) Campos onde as falhas no controle não podem ser atribuidas às condiçōes meteorológicas ou à germinação de plantas após a aplicação dos herbicidas, em pós-emergência;

d) Campos onde as plantas daninhas que escapam ao controle do herbicida estão distribuidas em reboleiras, e não em faixas ou linhas que seguem a direção da aplicação do herbicida.

e) Campos onde seja possivel relacionar um longo histórico de monocultivo e/ou uso continuado de herbicidas (ou mistura de herbicidas) com o mesmo mecanismo de ação.

Uma vez detectada a área onde pode ocorrer resistência, deve-se coletar amostras de plântulas (preferencialmente, no caso de gramineas) para ensaios rápidos de crescimento, ou coletar de plantas senescentes as sementes maduras que possam apresentar bom poder germinativo, para posteriores ensaios in vivo e in vitro, em laboratório.

\subsubsection{Determinação em laboratório}

\section{A) Ensaios in vivo:}

Estes estudos permitem que se conheça de forma qualitativa e quantitativa o nivel de resistência de uma planta daninha a um ou mais herbicidas. Uma das principais condiçōes para realização dos estudos de resistência é a comparação paralela do biotipo supostamente resistente com 
outro da mesma espécie, proveniente de um local nunca tratado com herbicida. A seguir sāo definidos alguns parâmetros determinados nos testes in vivo, para a caracterizaçāo de biotipos resistentes a herbicidas:

a) Dose letal (LD50, 70, 90): Dose de um herbicida capaz de matar 50, 70 ou 90\% dos individuos de uma amostra (espécie) em comparaçāo a outra amostra (espécie) nāo tratada com o herbicida;

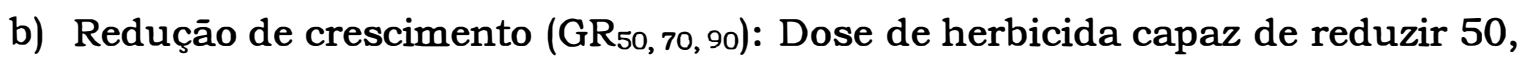
70 ou $90 \%$ da fitomassa recém-colhida ou seca, ou a porcentagem de controle dos individuos de uma amostra (espécie) em comparaçāo a outra amostra (espécie) nāo tratada com o herbicida;

c) Fator de resistência $\left(G R_{50} R / G_{50} S\right)$ : Valor do quociente entre a reduçāo de crescimento de um biotipo resistente $\left(G R_{50} R\right)$ e a reduçāo correspondente do biotipo sensivel (GR50S) da mesma espécie.

\section{B) Ensaios in vitro}

Enquanto os ensaios in vivo só permitem conhecer e quantificar a extensāo da resistência, os ensaios in vitro auxiliam no conhecimento das causas fisico-quimicas da resistência. A seguir, as caracteristicas determinadas nos testes in vitro, para comprovaçāo da resistência:

a) Caracterizaçāo molecular: A aplicaçāo das modernas técnicas da biologia molecular tem permitido o estudo de diferentes aspectos de relevância agronômica como: a capacidade de discriminar diferentes populações dentro de uma determinada espécie de planta, assim como identificar genes responsáveis por importantes caracteres, tais como aqueles envolvidos na produtividade, qualidades organolépticas, resistência a fatores bióticos e abióticos, etc...; 
b) Mecanismos de resistência: Existem pelo menos três mecanismos gerais, não necessariamente excluentes, que poderiam justificar a resistência a herbicidas: 1) Perda da afinidade pelo sítio de ação; 2) Redução na absorção e translocação do herbicida até o sítio de ação; e 3) Metabolização a compostos atóxicos.

\subsection{Estudo da resistência através de curvas de dose-resposta}

O estudo da resposta das plantas daninhas resistentes aos herbicidas tem sido realizado com freqüência por meio da análise de curvas de dose-resposta. Este procedimento permite, a cravés de gráficos, a interpretação dos resultados de forma objetiva e possibilita a comparação adequada do comportamento de um biotipo frente a um herbicida aplicado em diversas doses.

Um modelo log-logístico foi proposto por Seefeldt et al. (1995) como um método eficaz na análise de curvas dose-resposta. Os autores apresentaram neste trabalho sugestōes de procedimentos para utilização do programa SAS (Statistical Analysis System) na análise dos resultados. As curvas tipicas de dose-resposta apresentam formato sigmóide, sendo que a expressão matemática que relaciona a variável resposta y com a dose de herbicida $\mathbf{x}$ é:

$$
y=\frac{D-C}{1+\exp \left\{b\left[\log (x)-\log \left(G_{50}\right)\right]\right\}}+C
$$


em que: $\mathbf{D}$ corresponde à resposta aos tratamentos na dose máxima; C corresponde à resposta aos tratamentos na dose mínima; b é a declividade da curva e $\mathbf{G R}_{50}$ é a dose que produz $50 \%$ de inibiçāo na variável resposta.

Diversas respostas biológicas podem ser usadas para alimentar estes modelos, por exemplo: matéria seca produzida ou acumulada (Seefeldt et al., 1994; Wiederholt \& Stoltenberg, 1995); reduçāo de matéria seca e número de plantas sobreviventes (Stoltenberg \& Wiederholt, 1995); taxa de crescimento de caulículos e radículas (Murray et al.,1996).

Para a utilizaçāo deste modelo é necessário um adequado planejamento dos ensaios, com as doses em escala logaritmica.

Seefeldt et al. (1994), utilizaram o modelo log-logístico para determinar as curvas de dose-resposta de biotipos resistentes e suscetiveis de Avena fatua aos herbicidas diclofop-methyl, e outros herbicidas inibidores da ACCase. O modelo utilizado possibilitou estimar valores de $\mathrm{GR}_{50}$, as taxas de resistência e as diferenças significativas entre as respostas dos diversos biotipos estudados aos herbicidas. As curvas encontradas permitiram estimar valores de $\mathrm{GR}_{50}$ para os biotipos resistentes submetidos a herbicidas APP, entre 1 e 100 vezes maiores do que a resposta do biotipo suscetivel.

Modelos log-logisticos também foram empregados para estudar a resistência cruzada de biotipos de Digitaria sanguinalis e Setaria faberi (Wiederholt \& Stoltenberg, 1995; Stoltenberg \& Wiederholt, 1995). Uma populaçāo de Digitaria sanguinalis resistente a herbicidas inibidores da ACCase foi estudada por Wiederholt \& Stoltenberg (1995). Utilizando-se de modelos log-logisticos para elaboraçāo de curvas dose-resposta, foram obtidos altos e variados graus de resistência, comparados aos obtidos pela populaçāo suscetivel, a diversos herbicidas APP e CHD testados. Vários modelos loglogisticos foram utilizados por Stoltenberg \& Wiederholt (1995), ao estudarem um biotipo de Setaria faberi resistente aos inibidores da ACCase. O biotipo estudado apresentou variados graus de resistência aos herbicidas APP e CHD testados, quando foi analisada a reduçāo de biomassa seca produzida e plantas sobreviventes. 
Ao estudar os mecanismos de resistência de biotipos de Avena fatua ao diclofop, Seefeldt et al. (1996) utilizaram o modelo log-logistico para estimar os valores de I $_{50}$ (concentração de herbicida necessária para inibir em $50 \%$ a atividade enzimática). Os autores encontraram valores do grau de resistência em biotipos resistentes, ence 4 e 10 vezes superiores ao encontrados no biotipo suscetivel.

Outras respostas biológicas podem ser usadas como indicadores para o cálculo de curvas de dose-resposta. Murray et al. (1996) realizaram um bioensaio com sementes de Avena fatua como altenativa para comprovar a resistência a herbicidas inibidores da ACCase. Após um periodo de incubação das sementes, em meio contendo diferentes concentraçōes de herbicidas, os resultados de crescimento de radículas e cauliculos foram comparados com os do tratamento testemunha e utilizados para alimentar um modelo log-logístico. As curvas dose-resposta obtidas permitiram estimar valores elevados de GR50 para os parâmetros avaliados nos biotipos resistentes, em relação aos biotipos suscetiveis.

Para o estabelecimento de curvas de dose-resposta em função da escala de doses dos herbicidas e das variáveis resposta, nos casos em que o comportamento da variável dependente não segue um formato sigmóide, podem ser utilizados modelos como as equaçōes de regressāo lineares, quadráticos, hiperbólicos, exponenciais, etc... (Streibig et al., 1993; Heap et al., 1993; Sprague et al., 1997). Outros exemplos de funçōes não-lineares são descritos por Seber \& Wild (1989).

Os objetivos dos trabalhos deste capitulo foram:

- Determinar mediante bioensaios conduzidos em condiçōes controladas a resistência a herbicidas APP e CHD de populaçōes de B. plantaginea, coletadas na região sudoeste do Paraná (Guarapuava), suspeitas de serem resistentes;

- Estudar a resposta de biotipos resistentes de B. plantaginea aos herbicidas das classes APP e CHD, registrados no Brasil, e de estabelecer o grau de resistência destes biotipos. 


\section{MATERIAL E MÉTODOS}

\subsection{Avaliação preliminar da sensibilidade de populaçōes de Brachiaria plantaginea suspeitas de serem resistentes a herbicidas inibidores da ACCase}

\subsubsection{Seleção do material no campo}

Diante dos inúmeros casos suspeitos de resistência, apontados em várias localidades produtoras de soja no Paraná, foi efetuado um levantamento das áreas mais significativas para estudo, utilizando como critério de seleção o roteiro de questionário proposto pelo Comitê Brasileiro de Resistência de Plantas a Herbicidas (CBRPH). Nesta etapa, contamos com o apoio dos técnicos da FAPA - Fundação Agrária de Pesquisa Agropecuária e da Cooperativa Agrária Mista Entre Rios Ltda., ambas no municipio de Guarapuava/PR. Após o processo de seleção no qual foram eliminadas as possibilidades de falhas na tecnologia de aplicação, foram eleitas algumas áreas para coleta de amostras de sementes representativas de diferentes populações de B. plantaginea.

As áreas selecionadas são caracterizadas pela grande produção de soja, por utilizarem alta tecnologia agricola, e pelo uso intensivo de herbicidas, como principal técnica de controle de plantas daninhas. Nestas áreas, foram utilizados por mais de uma década, herbicidas graminicidas seletivos à soja, sendo todos pertencentes à classe dos inibidores da ACCase.

$\mathrm{O}$ histórico destas áreas, ao longo dos anos, mostrou um aumento significativo das infestações e a ocorrência de áreas com redução na eficácia de controle do capim-marmelada (Brachiaria plantaginea) pelos herbicidas APP e CHD, que inicialmente controlavam esta planta daninha na cultura da soja. 
Para cada área foi elaborado um histórico da utilização de herbicidas, com o fim de, se necessário, utilizá-los como subsídio ao monitoramento e análise evolutiva da resistência nas áreas em que fossem posteriormente confirmadas (Tabela 1 ).

As sementes de $B$. plantaginea suspeitas de resistência foram coletadas em campos agricolas de produtores de soja situados no municipio de Guarapuava/PR.

Tabela 1. Culturas de verão e herbicidas(1) utilizados nos campos de onde foram coletadas amostras de populações de $B$. plantaginea suspeitas de resistência a herbicidas inibidores da ACCase. Guarapuava/PR 1997.

\begin{tabular}{clllll}
\hline $\begin{array}{c}\text { POPU- } \\
\text { LAÇĀO }\end{array}$ & ANO (S) & CULTURA & \multicolumn{1}{c}{ HERBICIDA } & \multicolumn{1}{c}{$\begin{array}{c}\text { NOME } \\
\text { COMERCIAL }\end{array}$} & CLASSE \\
\hline $\mathbf{1}$ & $1993-1995$ & soja & fenoxaprop-p-ethyl & Podium & APP \\
& 1996 & soja & clethodim & Select & CHD \\
\hline $\mathbf{2}$ & $1991-1994$ & soja & sethoxydim & Poast & CHD \\
& $1995-1997$ & soja & clethodim & Select & CHD \\
\hline \multirow{3}{*}{$\mathbf{3}$} & 1994 & milho & atrazine & Stauzina & \\
& 1995 & soja & clethodim & Select & CHD \\
& 1996 & soja & sethoxydim & Poast & CHD \\
& 1997 & milho & atrazine & Stauzina & \\
\hline $\mathbf{4}$ & $1991-1994$ & soja & sethoxydim & Poast & CHD \\
& $1995-1997$ & soja & clethodim & Select & CHD \\
\hline \multirow{4}{*}{$\mathbf{5}$} & 1992 & soja & sethoxydim & Poast & CHD \\
& 1993 & milho & atrazine & Gesaprim & \\
& 1994 & soja & fenoxaprop-p-ethyl & Podium & APP \\
& 1995 & milho & atrazine + nicosulfuron & Gesaprim + Sanson & \\
& 1996 & soja & clethodim & Select & CHD \\
\hline $\mathbf{6}$ & $1994-1996$ & soja & sethoxydim & Poast & CHD \\
& 1997 & milho & atrazine & Atrazinax & \\
\hline $\mathbf{7}$ & $1994-1996$ & soja & clethodim & Select & CHD \\
& 1997 & milho & atrazine & Gesaprim & \\
\hline
\end{tabular}

(I) Os herbicidas foram utilizados em pós-emergência nas doses de campo recomendadas.

Fonte: Cooperativa Mista Agrária de Entre Rios Ltda. 


\subsubsection{Tratamento de sementes para quebra de dormência}

As sementes foram preliminarmente testadas para o conhecimento prévio das condiçōes de germinaçāo e da possivel necessidade do uso de técnicas para a quebra de dormência. Comprovada a ocorrência de dormência utilizou-se a técnica de quebra de dormência com a imersāo das sementes em ácido sulfúrico por 30 minutos, segundo a metodologia apresentada por Freitas et al., 1993.

\subsubsection{Local}

O experimento foi conduzido em casa-de-vegetaçāo do Departamento de Produçāo Vegetal da Escola Superior de Agricultura "Luiz de Queiroz", da Universidade de Sāo Paulo, Piracicaba/SP.

\subsubsection{Material vegetal}

As sementes foram coletadas em áreas produtoras de soja, suspeitas de serem resistantes a herbicidas, após a colheita da soja da safra 96/97. As sementes foram coletadas de várias plantas que sobreviveram aos tratamentos com herbicidas inibidores da ACCase. Foram coletadas as sementes presentes no solo, liberadas naturalmente pelas plantas, para garantir um bom estádio de maturidade fisiológica das mesmas. Estas áreas apresentavam histórico de manejo de plantas daninhas de folhas estreitas com uso intensivo de herbicidas APP e CHD por vários anos consecutivos.

As amostras de sementes coletadas no campo foram secas ao ar, e purificadas separando-se de terra, material inerte e sementes chochas. Depois disso, as sementes resistentes e as suscetiveis, provenientes de áreas nunca antes tratadas com herbicidas, foram submetidas separadamente a tratamento para quebra de dormência, conforme descrito no item 2.1.2. 
As sementes de sete populaçōes suspeitas de serem resistentes e uma população suscetivel foram semeadas separadamente, em bandejas de 30 x $50 \times 10 \mathrm{~cm}$, contendo uma mistura de solo e matéria orgânica, na proporção 3:1, conforme análise de solo apresentada na Tabela 2. Aos sete dias após a semeadura realizou-se o transplante para vasos plásticos com capacidade de $500 \mathrm{~mL}$, mantendo a densidade de quatro plantas por vaso. Os vasos continham o mesmo substrato utilizado nas bandejas e, após o transplante, foram irrigados diariamente visando a manutenção de umidade satisfatória. Aos sete dias após o transplante realizou-se uma adubação com a fórmula 1818-18 na concentração de $0,6 \mathrm{~g} \mathrm{~L}^{-1}$ de água.

Tabela 2. Análises(1) química e granulométrica do substrato utilizado no bioensaio com populaçōes de $B$. plantaginea, em casa-devegetação. Piracicaba/SP - 1999.

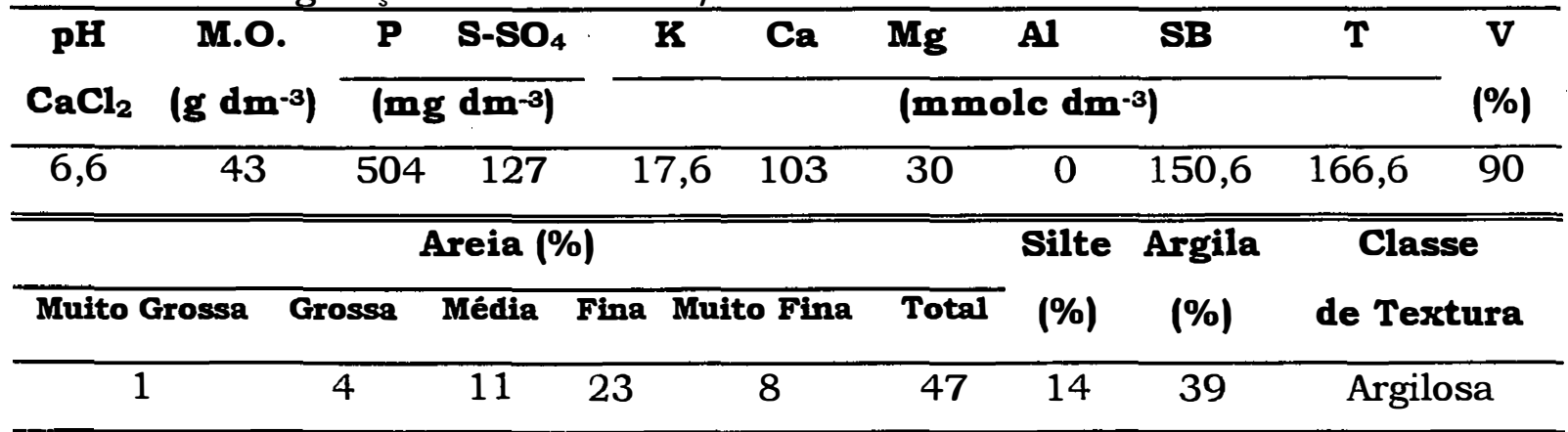

-(1) Resultados fornecidos pelo Laboratório de Análises de Solos do Departamento de Ciência do Solo - ESALQ/USP.

\subsubsection{Tratamentos}

O delineamento experimental utilizado foi $o$ inteiramente casualizado, em esquema fatorial ( $8 \times 3 \times 4)$ utilizando-se sementes de 8 populaçōes (1 suscetivel e 7 suspeitas de resistência), 3 herbicidas e 4 dosagens, num total de 96 tratamentos e quatro repetiçōes. Os herbicidas utilizados com suas respectivas doses e sua nomenclatura estão descritos na Tabela 3. 
Tabela 3. Tratamentos utilizados no bioensaio em casa-de-vegetação com populações de $B$. plantaginea suspeitas de serem resistentes a herbicidas inibidores da ACCase. ESALQ/USP - Piracicaba/SP 1997.

\begin{tabular}{|c|c|c|c|c|c|}
\hline \multicolumn{2}{|c|}{ HERBICIDAS(1) } & \multirow{2}{*}{$\begin{array}{c}\text { Concentração } \\
\text { de i.a. (2) } \\
\text { g L -1 } \\
\end{array}$} & \multicolumn{2}{|c|}{ Dose aplicada } & \multirow{2}{*}{$\begin{array}{l}\text { No vezes } \\
\text { dose de } \\
\text { campo (D) }\end{array}$} \\
\hline Nome comum & $\begin{array}{c}\text { Nome } \\
\text { comercial } \\
\end{array}$ & & $\begin{array}{c}\text { de p.c. }{ }^{(3)} \\
\text { L ha }{ }^{-1}\end{array}$ & $\begin{array}{l}\text { de i.a. } \\
\text { g ha-1 }\end{array}$ & \\
\hline & & & 0 & 0 & 0 \\
\hline \multirow[t]{4}{*}{ sethoxydim(4) } & Poast & 184 & 1.25 & 230 & $1 \mathrm{D}$ \\
\hline & & & 2.5 & 460 & $2 \mathrm{D}$ \\
\hline & & & 5.0 & 920 & $4 \mathrm{D}$ \\
\hline & & & 0 & 0 & 0 \\
\hline \multirow[t]{4}{*}{ fluazifop-p-butil } & Fusilade & 125 & 2.0 & 250 & $1 \mathrm{D}$ \\
\hline & & & 4.0 & 500 & $2 \mathrm{D}$ \\
\hline & & & 8.0 & 1000 & $4 \mathrm{D}$ \\
\hline & & & 0 & 0 & 0 \\
\hline \multirow[t]{3}{*}{ fenoxaprop-p-ethyl } & Podium & 110 & 0.82 & 90 & $1 \mathrm{D}$ \\
\hline & & & 1.64 & 180 & $2 \mathrm{D}$ \\
\hline & & & 3.28 & 360 & $4 \mathrm{D}$ \\
\hline
\end{tabular}

(1) Herbicidas aplicados em pós-emergência

(2) i.a. = ingrediente ativo

(3) p.c. = produto comercial

(4) Recebeu a adição de Assist 0,5 \% v:v

Os herbicidas utilizados neste ensaio foram escolhidos segundo o critério dos mais utilizados, dentro dos grupos quimicos APP e CHD, nas regiōes de origem das sementes. Antes da pulverização foram selecionados vasos com plantas de aspecto uniforme e apresentando, em média, a emissão do primeiro perfilho.

Os herbicidas foram pulverizados sobre a parte aérea das plantas, utilizando-se um pulverizador pressurizado com ar comprimido e instalado em laboratório, com ponta de pulverização do tipo leque (Teejet 80.03E), com jato calibrado na altura de $50 \mathrm{~cm}$ da superficie do alvo. Os herbicidas foram 
aplicados dissolvidos em água a um volume de pulverização correspondente a $300 \mathrm{~L} \mathrm{ha}^{-1}$ de calda , numa pressão de $40 \mathrm{lb} \mathrm{pol}-2$.

Após a pulverização as plantas foram mantidas em casa-devegetaçāo, sendo irrigadas diretamente no solo, diariamente.

\subsubsection{Avaliaçōes}

O efeito dos tratamentos sobre o crescimento das plantas foi avaliado com a porcentagem de controle visual, aos 7 e 14 dias após a aplicação (DAA) dos herbicidas, e a fitomassa da parte aérea coletada acima da superfície do solo, recém-colhida aos 15 DAA.

As avaliaçōes de controle de plantas daninhas foram efetuadas empregando-se escala visual, considerando-se $0 \%$ para nenhum controle, e $100 \%$ para controle total, comparados à testemunha sem herbicida.

\subsubsection{Análise dos dados}

Os dados originais de porcentagem de controle e produção de fitomassa foram submetidos aos testes de Lilliefors (1967) para verificar a normalidade dos mesmos, e ao teste de Barttlet (1937) para verificar a homogeneidade das variâncias. Nos casos em que os dados nāo apresentavam distribuição normal ou variâncias homogêneas, foram utilizadas transformaçōes nos dados, conforme com a variável testada.

Os dados foram submetidos à análise de variância, utilizando-se o programa SAS1. As médias significativas pelo teste de $\mathrm{F}$ a $5 \%$ de probabilidade (Tabela A1 - Anexo), foram diferenciadas pelo teste de Tukey a $5 \%$ de significância.

\footnotetext{
${ }^{1}$ SAS - Statistical Analisys System Institute, Cary, NC (versão 6.0) 27512.
} 
Os resultados obtidos após análise orientaram a escolha das populaçōes que apresentaram menores niveis de controle com os ratamentos testados. As populaçōes selecionadas foram utilizadas na etapa seguinte desta pesquisa, para determinação da taxa de resistência.

\subsection{Avaliação da resistência cruzada e da taxa de resistência de biotipos de Brachiaria plantaginea}

A partir desta etapa as populações anteriormente selecionadas passaram a ser denominadas biotipos. O objetivo nesta etapa foi a determinação dos niveis de resistência encontrados nos diferentes biotipos de B. plantaginea selecionados. Isto foi realizado por meio da determinação do GR50 (dose de herbicida necessária para reduzir 50\% do controle e/ou da produção de fitomassa), para cada biotipo.

\subsubsection{Local}

Os experimentos foram conduzidos em casa-de-vegetação da Estação Experimental da Empresa Zeneca Brasil Ltda., em Holambra/SP.

\subsubsection{Material vegetal}

As sementes dos biotipos selecionados e das suscetiveis foram semeadas em bandejas contendo substrato à base de solo e matéria orgânica, na proporção de 3:1 (Tabela 4).

Nove dias após a semeadura, foi realizado o transplante das mudas estabelecendo-se a densidade de quatro plantas por vaso.

As plântulas dos biotipos resistentes e do suscetivel foram transplantadas separadamente para vasos plásticos com capacidade de 500 
$\mathrm{mL}$, contendo o mesmo substrato utilizado nas bandejas. Oito dias após o transplante realizou-se uma adubação com a fórmula 18-18-18 na concentração de $0,6 \mathrm{~g} \mathrm{~L}^{-1}$ de água. Os vasos foram irrigados diariamente visando a manutenção de umidade satisfatória.

Tabela 4. Análises(1) química e granulomécrica do substrato utilizado no bioensaio com biotipos de B. plantaginea, em casa-de-vegetação. Piracicaba/SP - 1999.

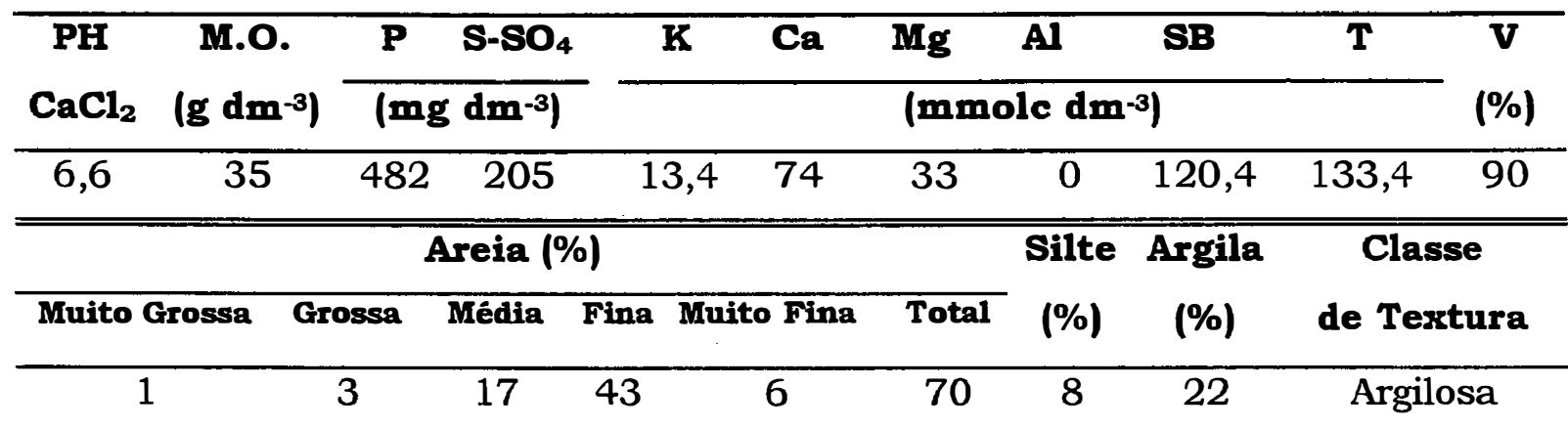

(n) Resultados fornecidos pelo Laboratório de Análises de Solos do Departamento de Ciência do Solo ESALQ/USP.

\subsubsection{Tratamentos}

Neste ensaio foram testados todos os herbicidas inibidores da ACCase, pertencentes aos grupos quimicos APP e CHD, registrados no Brasil, na ocasião. Para cada herbicida foram avaliadas a dosagem de campo recomendada e para uso no campo doses abaixo e acima da recomendada. As dosagens variaram de acordo com os herbicidas, porém procurou-se utilizar as que proporcionassem um mínimo de $50 \%$ no controle dos biotipos estudados $\left(\mathrm{GR}_{50}\right)$.

As doses foram selecionadas a partir de ensaios preliminares nos quais se buscou conhecer a melhor escala a ser utilizada. A escala logaritmica, de base 4 , foi a que melhor se ajustou aos objetivos deste trabalho. 
O delineamento experimental utilizado foi o inteiramente casualizado, em esquema fatorial $(3 \times 9 \times 7)$ com 3 populaçōes [1 suscetivel (S) e 2 resistentes $(\mathrm{A}$ e $\mathrm{B}$ )], 9 herbicidas e 7 dosagens, num total de 189 tratamentos e quatro repetiçōes. Os tratamentos estão descritos na Tabela 5 .

Para receber os tratamentos com herbicidas foram selecionados vasos com plantas uniformes e vigoross, apresentando, em média, o segundo perfilho emitido.

Os herbicidas foram pulverizados sobre a parte aérea das plantas, utilizando-se um pulverizador pressurizado com ar comprimido e instalado em laboratório, com ponta de pulverização do tipo leque (Teejet 80.015E), com jato calibrado numa altura média de $50 \mathrm{~cm}$ da superficie do alvo. Os herbicidas foram aplicados dissolvidos em água a um volume de pulverizaçāo correspondente a $200 \mathrm{~L} \mathrm{ha}^{-1}$ de calda , numa pressão de $40 \mathrm{lb} \mathrm{pol}-2$. Os vasos tratados com propaquizafop e haloxyfop-methyl receberam uma camada de palha de arroz seca sobre o solo, antes da pulverização, com o objetivo de eliminar o contato destes herbicidas com o solo, evitando assim a absorção radicular e seus possiveis efeitos.

Após a pulverização, as plantas foram mantidas em casa-devegetaçāo, sendo irrigadas dirariamente diretamente no solo, para evitar que os herbicidas fossem lavados das folhas.

\subsubsection{Avaliaçōes}

O efeito dos tratamentos sobre os biotipos de $B$. plantaginea foi avaliado com a porcentagem de controle visual, aos 7 e 14 dias após a aplicação dos herbicidas (DAA), e a fitomassa recém-colhida aos 15 DAA, da parte aérea coletada acima da superficie do solo.

As avaliaçōes de controle de plantas daninhas foram efetuadas empregando-se escala visual, considerando-se $0 \%$ para nenhum controle e $100 \%$ para controle total, comparados à testemunha sem herbicida. 


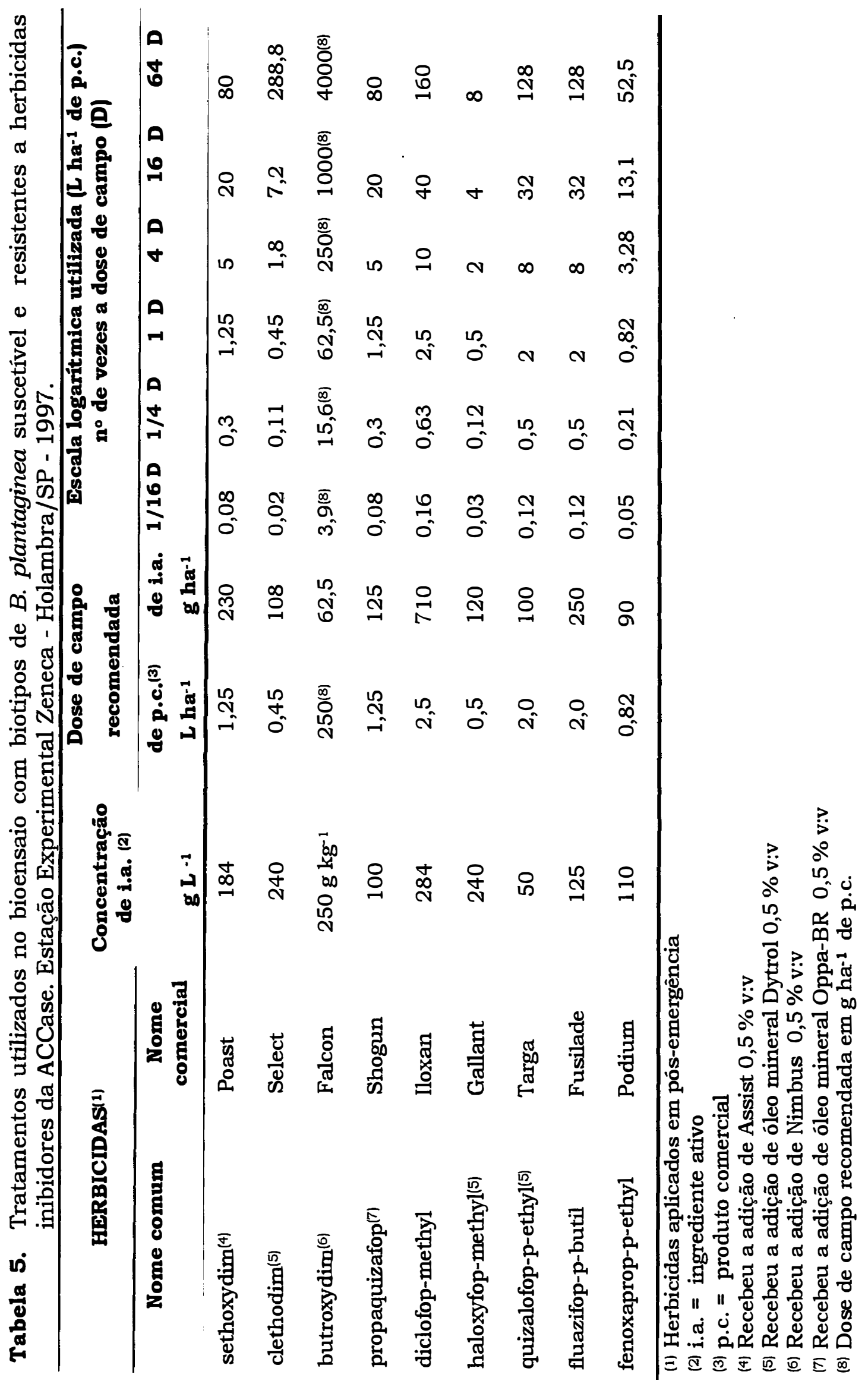




\subsubsection{Análise dos dados}

Os resultados das avaliaçōes foram submetidos à confirmação da homogeneidade de variâncias pelo teste de Barttlet (1937) e verificada a normalidade dos dados pelo teste de Lilliefors (1967). Quando os dados não apresentavam distribuição normal ou variâncias homogêneas, foram utilizadas transformaçōes nos dados, conforme a variável testada.

Os dados foram submetidos à análise de variância, utilizando-se o programa SAS. As médias significativas pelo teste de $\mathrm{F}$ a $5 \%$ de probabilidade (vide Anexo -Tabela A1), foram diferenciadas pelo teste de Tukey a $5 \%$ de significância.

Posteriormente, os dados foram ajustados ao modelo log-logístico proposto por Seefeldt et al. (1995) (vide item 1.3), visando estimar o valor de GR50 a partir das curvas de dose-resposta obtidas para cada biotipo e herbicida testados.

Os dados de produção de fitomassa não foram ajustáveis ao modelo log-logistico por causa da grande dispersão neles encontrada. Por isso, estes dados foram submetidos a um modelo de regressão exponencial cuja expressão matemática é uma variante de modelos exponenciais apresentados por Pereira \& Arruda (1987), em que:

$$
y=a+b \exp (-x / t)
$$

y é a variável resposta (produção de fitomassa); a, b e t são parâmetros estimados e $x$ é a variável independente (dose de herbicida que proporciona a resposta de fitomassa).

O biotipo B, tratado com sethoxydim, apresentou dados de produção de fitomassa que não foram ajustáveis a nenhum dos modelos 
utilizados anteriormente. Por esta razão estes dados foram ajustados ao modelo linear descrito abaixo, em que:

$$
y=a+b x
$$

y é a variável resposta (produção de fitomassa), a e b são parâmetros estimados e x é a variável independente (dose de herbicida que proporciona a resposta de fitomassa). Para os modelos exponencial e linear, os valores de $\mathrm{GR}_{50}$ foram calculados através das equaçōes matemáticas que expressam os modelos, substituindo-se os valores de $\boldsymbol{g}$ por metade $(50 \%)$ dos valores estimados.

Uma vez determinada a taxa de resisitência de cada biotipo de $B$. plantaginea testados, escolheu-se aquele que apresentou a maior taxa de resistência [GR50 (biotipo R)/GR50 (biotipo S)], como objeto de experimentação para os estudos posteriores de mecanismo de resistência.

\section{RESULTADOS E DISCUSSĀO}

3.1 Avaliação preliminar da sensibilidade de populações de Brachiaria plantaginea suspeitas de serem resistentes a herbicidas inibidores da ACCase

Com o objetivo de caracterizar as diferenças de suscetibilidade a herbicidas inibidores da ACCase sobre diferentes populaçōes de B. plantaginea, estudou-se o efeito destes herbicidas sobre o crescimento de diferentes populaçōes. 
Os resultados de porcentagem de controle aos 7 dias após aplicação (DAA) dos herbicidas estão apresentados na Tabela 1. Na avaliação de controle aos 7 DAA, foram verificadas diferenças significativas entre herbicidas e doses, dentro de cada população avaliada, sendo também significativas as diferenças encontradas entre as populações (Tabela A1 anexo/resumo da analise de variância).

Analisando-se os dados dentro de populações aos 7 DAA, verificou-se que os herbicidas, em suas diferentes doses, não apresentaram diferenças significativas para a população $\mathrm{S}$ e $\mathrm{P5}$, sendo estas as que apresentaram maiores niveis de controle. O herbicida sethoxydim apresentou os menores resultados de controle, mesmo em doses acima da recomendada, para as populações $\mathrm{P} 1, \mathrm{P} 2, \mathrm{P} 3$ e $\mathrm{P} 4$. Os menores niveis de controle com os herbicidas fluazifop e fenoxaprop foram obtidos com as populaçōes P7 e P6, respectivamente. Nas doses acima da recomendada, verificou-se um sensivel acréscimo nos niveis de controle observados para todos os herbicidas, sendo que os herbicidas sethoxydim e fenoxaprop apresentaram controles significativamente menores, nas populações P2 e P4. Entre as populações testadas, somente a P2 apresentou níveis de controle significativos reduzidos, para todos os herbicidas e doses testadas. Tanto a população P2 como a P4 apresentaram controles significativamente reduzidos e equivalentes para o herbicida sethoxydim, em todas as doses, e para o fenoxaprop na dose 4 vezes a recomendada.

Os resultados de porcentagem de controle aos 14 dias após aplicação (DAA) dos herbicidas estão apresentados na Tabela 2 e Figura 1. Aos 14 DAA os niveis de controle proporcionados pelos herbicidas nas doses utilizadas foram estatisticamente iguais dentro de cada população testada, sendo porém significativas as diferenças das medias de controle obtidas pelos herbicidas entre as populações (vide Anexo - Tabela A1).

$\mathrm{Na}$ avaliação de controle aos 14 DAA, foi determinada a diferença significativa da população P2 em relação às demais, apresentando o menor resultado médio de controle $(11,7 \%)$ na dose recomendada, para todos os 


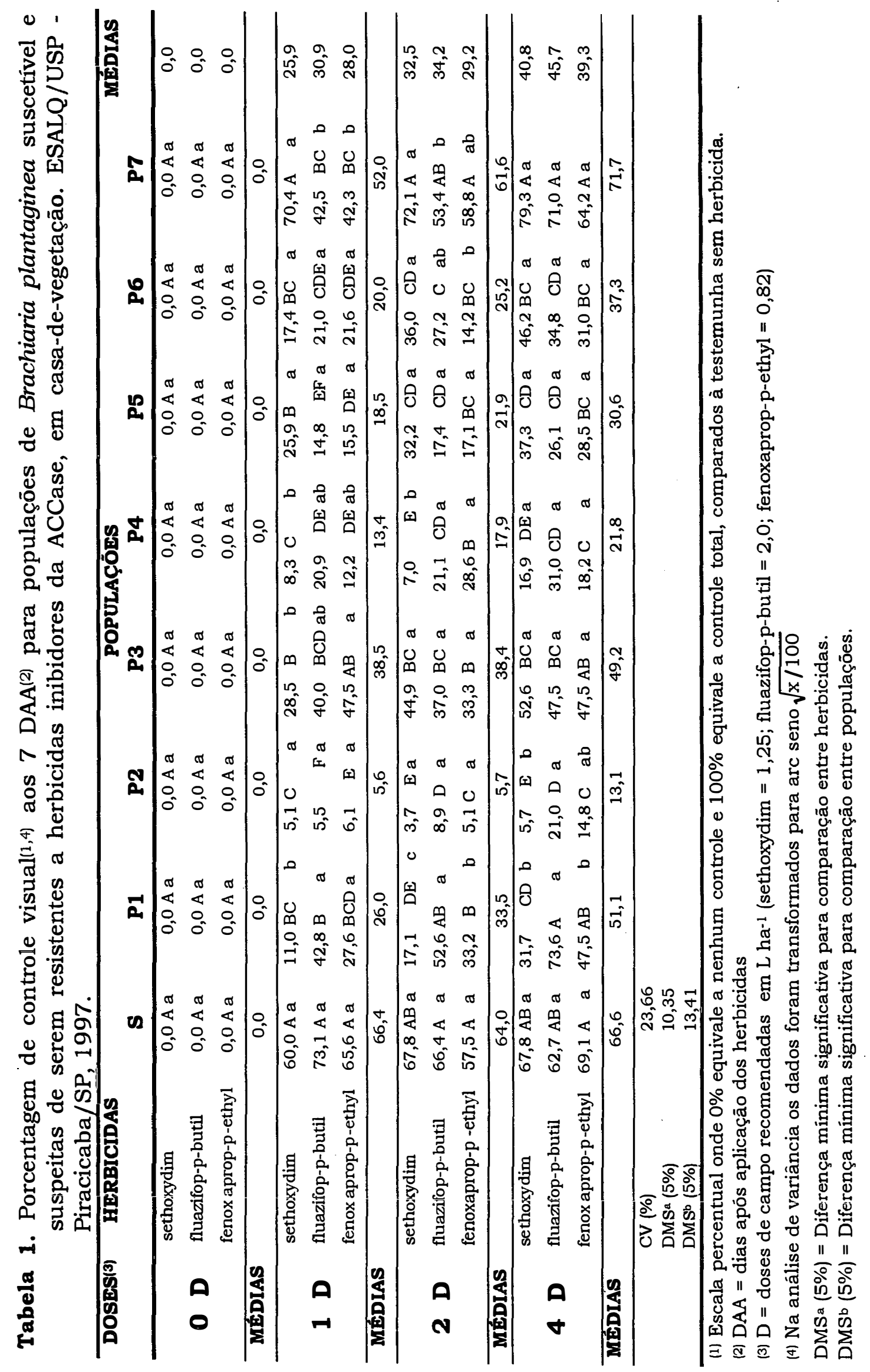




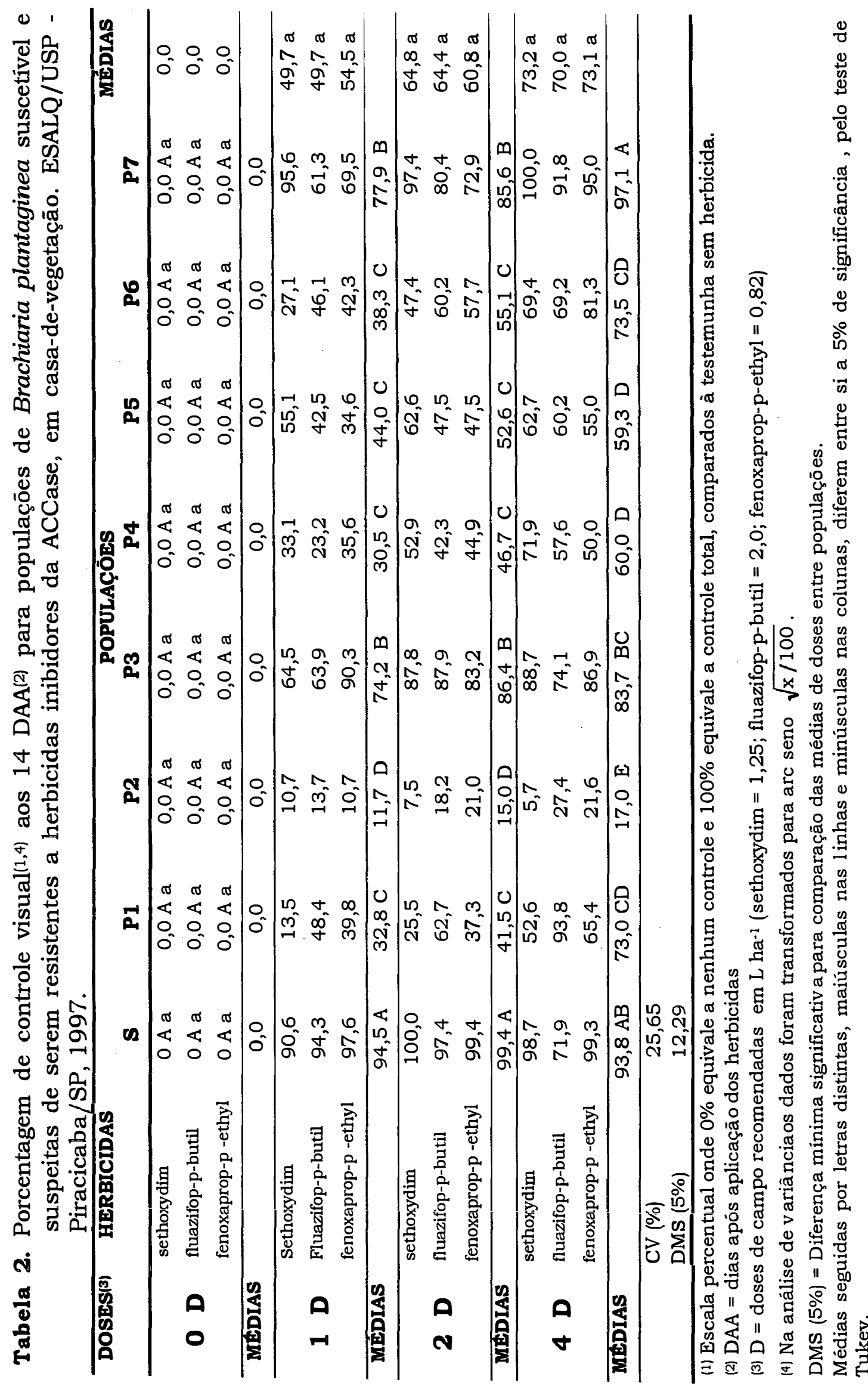




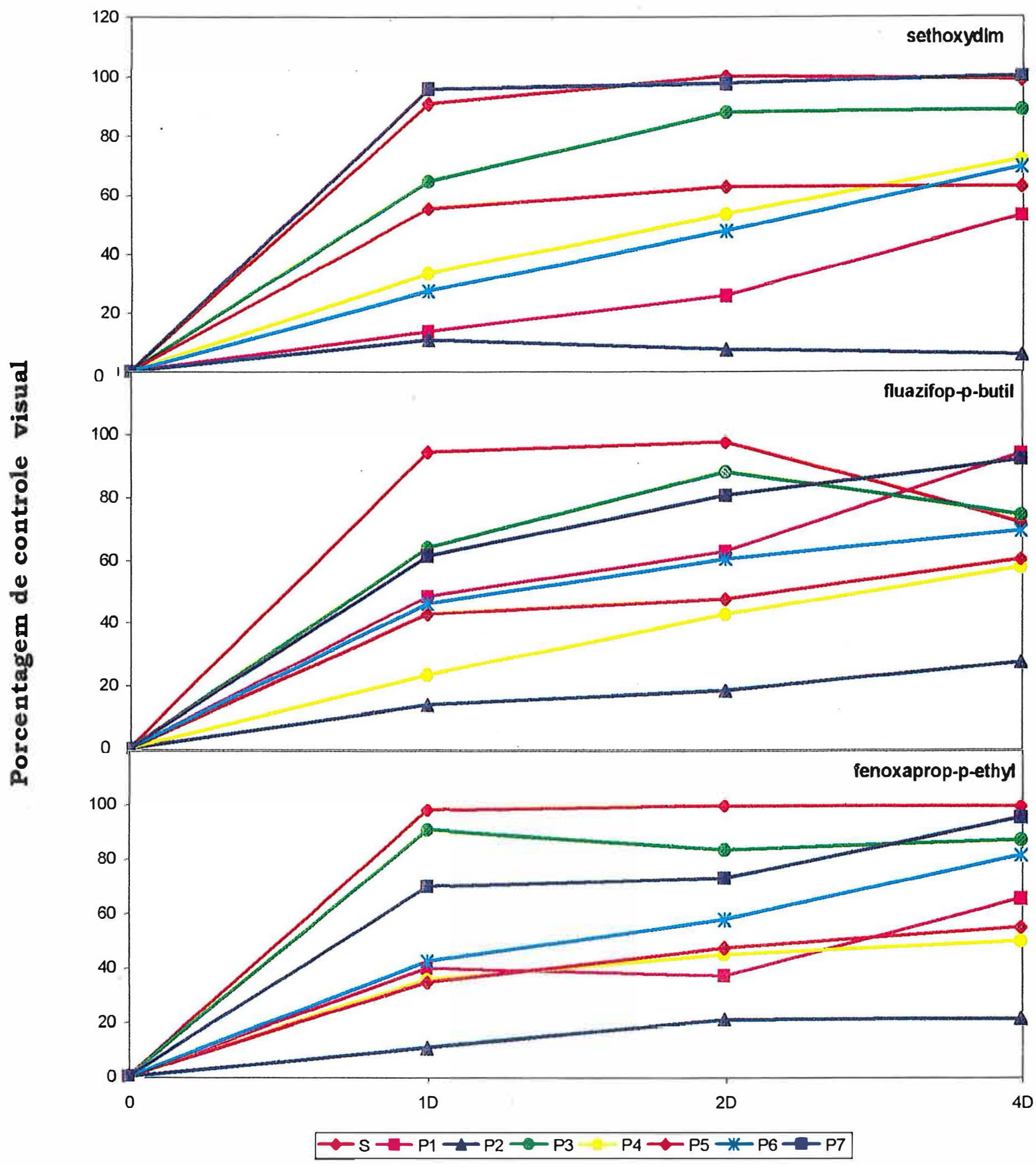

Figura 1. Efeito de herbicidas inibidores da ACCase sobre o percentual de controle visual aos 14 DAA, em populaçōes de Brachiaria plantaginea.

$\left[D=\right.$ dose de campo recomendada $\left(\mathrm{L} \mathrm{ha}^{-1}\right)$ : sethoxydim $=1,25$; fluazifop-p-butil $=2,0$ e fenoxaprop-p-ethyl $=0,82]$. 
herbicidas tratados. Na seqüência, foram consideradas estatisticamente iguais em relaçāo aos resultados de controle obtidos com todos os herbicidas na dose recomendada, as populações $\mathrm{P} 1, \mathrm{P} 4$, $\mathrm{P} 5$ e $\mathrm{P} 6$, apresentando 32,8\%, 30,5\%, $44,0 \%$ e $38,3 \%$ de controle, respectivamente. Embora, sem significância estatistica, as populações P1 e P2 apresentaram os menores resultados de controle $(13,5 \%$ e $10,7 \%$, respectivamente) com sethoxydim, na dose recomendada; as populações $\mathrm{P} 2$ e $\mathrm{P} 4$ apresentaram os menores resultados de controle $(13,7 \%$ e $23,2 \%$, respectivamente) com o fluazifop, na dose recomendada. Nas doses 2 e 4 vezes a recomendada, a populaçāo P2 novamente se apresentou com os menores resultados médios de controle obtidos (15,0\% na dose $2 \mathrm{D}$ e $17,0 \%$ na dose 4D), diferenciando-se significativamente das demais populações. Os herbicidas sethoxydim, fluazifop e fenoxaprop exerceram diferentes efeitos entre as distintas populações, sendo controlada eficazmente, em todas as doses, somente a populaçāo sensivel.

Neste bioensaio realizado com diferentes populações e herbicidas em várias doses, verificou-se que a evoluçāo da fitomassa das plantas tratadas em relaçāo às plantas nāo tratadas foi significativamente diferente. Estes resultados estāo apresentados na Tabela 3 e Figura 2.

$\mathrm{Na}$ avaliaçāo de fitomassa obtida, foram verificadas diferenças significativas entre herbicidas e suas doses, dentro de cada populaçāo avaliada, sendo também significativas as diferenças encontradas entre as populações (vide Anexo - Tabela A1).

A populaçāo $S$ apresenta reduçāo significativa de fitomassa nas doses recomendadas dos herbicidas utilizados. As maiores produções de fitomassa, em relaçāo à media obtida dos tratamentos com herbicidas, foram alcançadas pelas populações $\mathrm{P} 1, \mathrm{P} 2$ e $\mathrm{P} 6$, sendo que estas duas últimas apresentaram fitomassas equivalentes a das testemunhas sem herbicidas, na dose recomendada dos herbicidas. Este fato evidencia que estas populações mostraram-se como as menos afetadas pelos herbicidas.

A Figura 2 apresenta os mesmos dados experimentais (fitomassa recém-colhida), expressos em porcentagem de produçāo de fitomassa recém- 


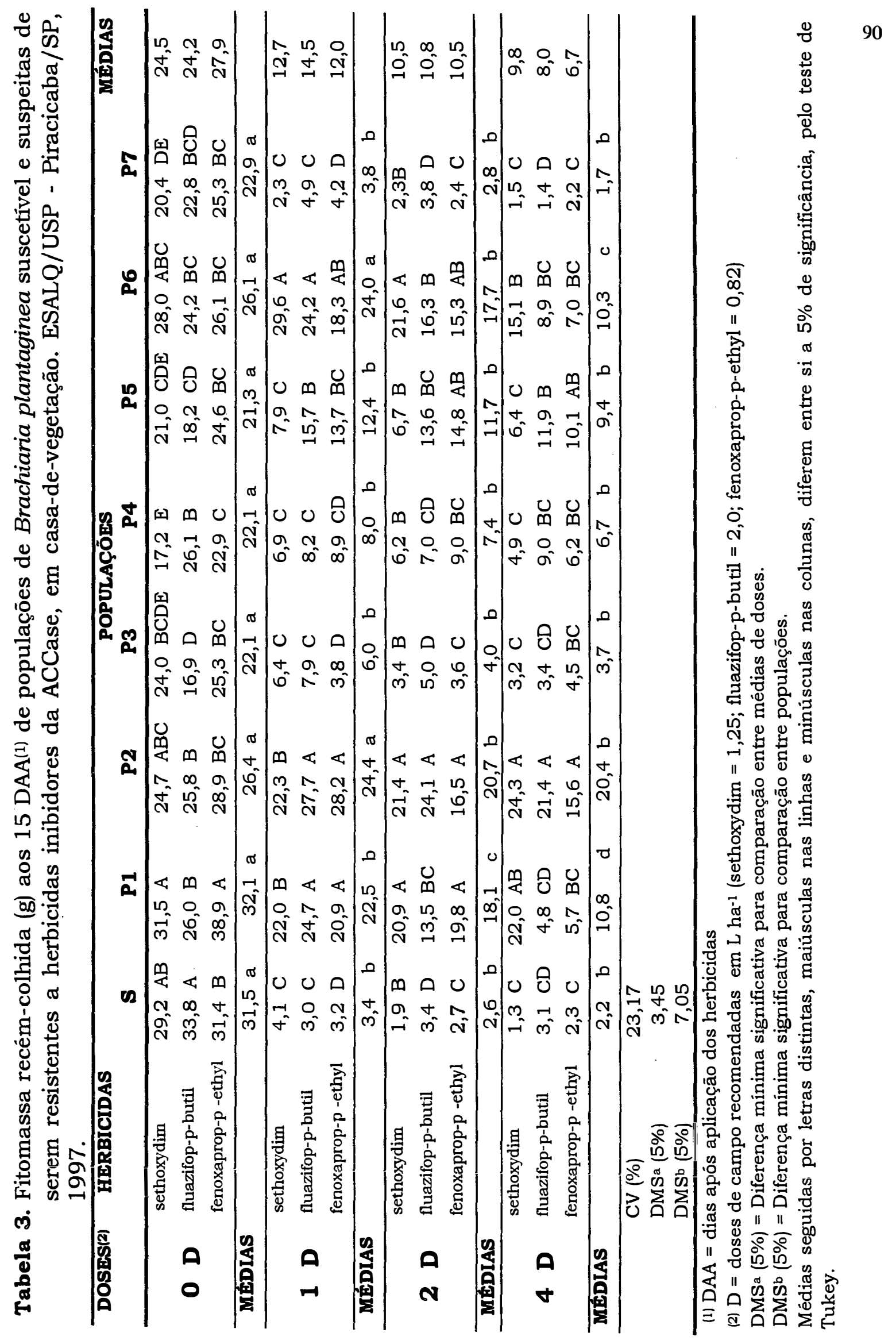




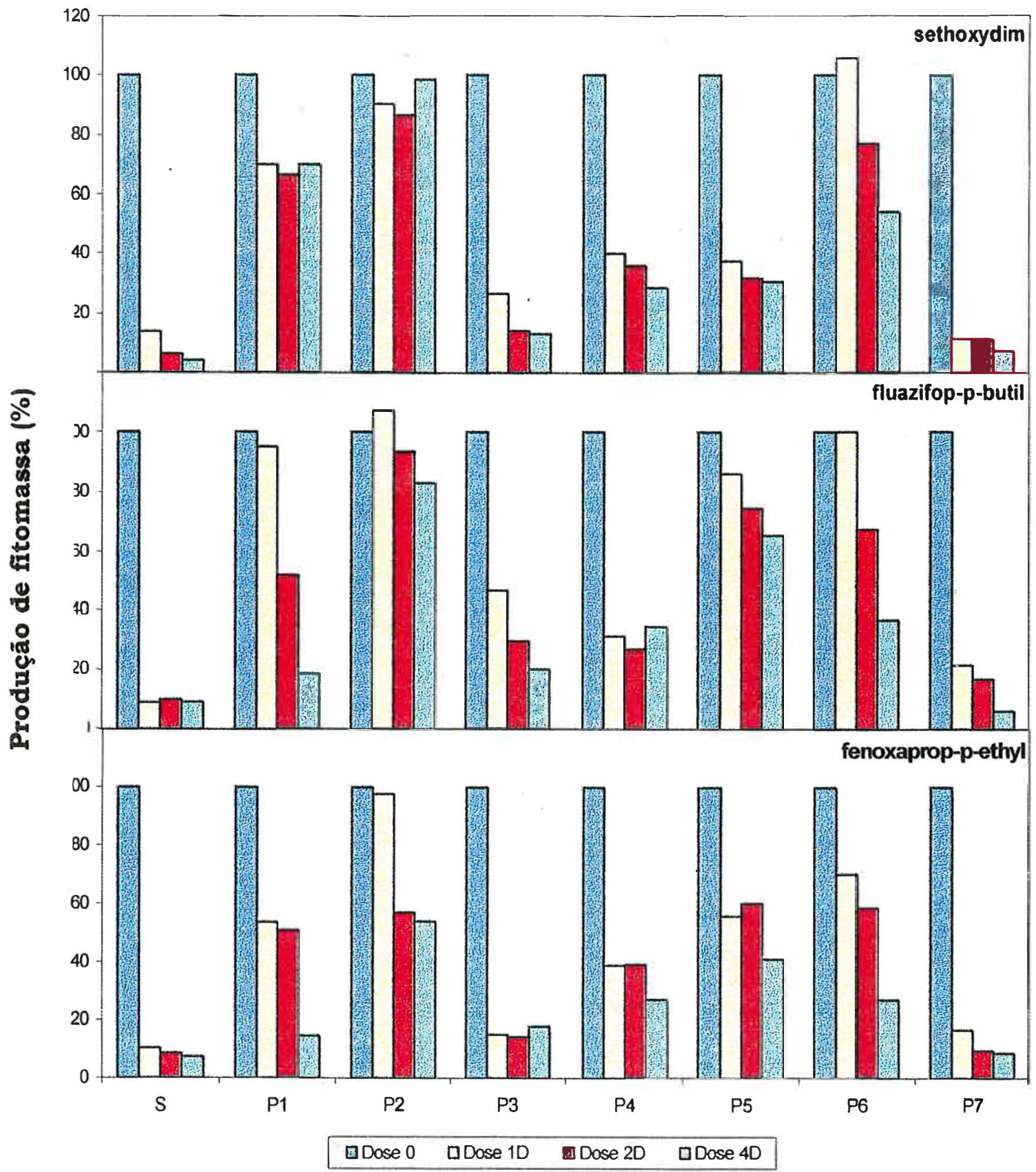

Figura 2. Porcentagem de fitomassa produzida em relação ao tratamento sem herbicida, em populaçōes de Brachiaria plantaginea tratadas com diferentes doses de herbicidas inibidores da ACCase.

$[D=$ dose de campo recomendada em $(\mathrm{L}$ ha-1): sethoxydim $=1,25$;

fluazifop-p-butil $=2,0$ e fenoxaprop-p-ethyl $=0,82]$.

$\mathrm{S}=$ população suscetivel

P1 a P7 = populações suspeitas de serem resistentes 
colhida em relação à testemunha sem herbicida. Esta forma de representação permite uma análise visual comparativa dos resultados obtidos por cada população testada. Dessa forma, é possivel notar que a tendência dos dados é a mesma, com algumas variações devido ao efeito dos diferentes herbicidas e doses utilizados. Cada porcentagem foi obtida a partir da média de produção de fitomassa das testemunhas da respectiva população.

As populações que apresentaram menores reduções de fitomassa em relação ao herbicida sethoxydim foram as P1 e P2. A população P2 destacou-se das demais, como a que sofreu menor redução de fitomassa para todos os herbicidas e doses testadas, evidenciando assim o alto grau de insensibilidade desta população a esses produtos. $O$ herbicida fluazifop foi $o$ que proporcionou menores redução na produção de fitomassa, na dose recomendada, para as populações P1, P2 e P6 (Figura 2).

Os resultados apresentados na Tabela 2 comprovam que, para o herbicida sethoxydim as populações menos sensiveis foram as P2 e P6; para o fluazifop as populações menos sensiveis foram as P2, P5 e P6; e para o fenoxaprop-p-ethyl as populações menos sensiveis foram as P2, P5 e P6. As populaçōes P2, P5 e P6, de modo geral, foram as mais tolerantes aos herbicidas utilizados, e a população $\mathrm{S}$ foi de fato a mais sensivel aos herbicidas testados.

Pode-se inferir que as sementes provenientes destas populações mais tolerantes foram provenientes de áreas cultivadas com soja, onde houve a seleção de biotipos resistentes de $B$. plantaginea a herbicidas inibidores da ACCase. A aplicação destes herbicidas para o controle de plantas daninhas de folhas estreitas durante vários anos, nestas áreas, aumentou a freqüência de alelos resistentes a estes herbicidas, atingindo um nivel considerado crítico, uma vez que os indices de controle obtidos nas doses recomendadas são insatisfatórios.

A seleção mediante repetidos tratamentos com herbicidas APP e CHD (Material e Métodos - Tabela 1) em populações de B. plantaginea no campo, pode haver selecionado não somente populações com atividade enzimática diferenciadas, ou um biotipo resistente ao herbicida CHD 
sethoxydim, como também gerar um fenômeno de resistência cruzada a diversos herbicidas utilizados.

Nestas áreas, a competição interespecifica se dava predominantemente entre a cultura da soja e infestaçōes de $B$. plantaginea, em alta densidade. Os herbicidas utilizados exerceram uma elevada preśsão de seleção, praticamente eliminando outras plantas daninhas. Esta caracteristica é apontada por Mallory-Smith et al. (1993) como indicativa da probabilidade de ocorrência de resistência.

Outro aspecto importante a ser considerado é a habilidade reprodutiva e a prolificidade da planta daninha B. plantaginea (Freitas, 1991). $\mathrm{O}$ grande número de geraçōes sucessivas em um ano e o grande número de sementes produzidas (Kissmann $\&$ Groth, 1991) fazem com que esta espécie apresente um grande potencial para o aparecimento de resistência. Desta forma, estas características estão relacionadas ao sucesso na adaptação ecológica, segundo Silvertown (1987), com reflexos na sobrevivência e disseminação.

As variaçōes de sensibilidade entre populaçōes de plantas daninhas e entre herbicidas são freqüentemente observadas, e atribuídas a mais de uma alteração no mecanismo de resistência prevalecente nas espécies, como relatado por Devine \& Shimabukuro, 1994 e Devine, 1997).

Diante dos resultados obtidos, foram escolhidas as populaçōes P2 e P5, agora denominadas biotipos A e B, respectivamente, para prosseguir nos ensaios seguintes. A partir deles, será determinada a existência de resistência cruzada e as taxas de resistência a diversos herbicidas APP e CHD.

A escolha da população menos sensivel poderia haver recaído também sobre a população 6 , porém foram considerados aspectos de uniformidade e poder de germinação das semente da populaçào 5 . 


\subsection{Avaliaçāo da resistência cruzada e da taxa de resistência em biotipos de Brachiaria plantaginea}

Na avaliação de controle visual aos 7 e 14 DAA (Tabela 4) foram verificadas diferenças significativas entre herbicidas e suas doses, para cada biotipo avaliado, sendo também significativas as diferenças encontradas entre os biotipos (Tabela A2- anexo/resumo da análise de variância).

Aos 7 DAA para os biotipos resistentes, os herbicidas nas doses de campo recomendadas não foram suficientes para controlar o crescimento das plantas. Em todas as doses e herbicidas testados verificou-se a maior sensibilidade do biotipo suscetivel, o qual expressou niveis de controle significativamente superiores. Acima das doses recomendadas, o biotipo A apresentou-se com controles equivalentes aos da população suscetivel, para os herbicidas clethodim e butroxydim. De maneira geral, abaixo das doses recomendadas, os biotipos A e B apresentaram maior tolerância aos herbicidas sethoxydim e fenoxaprop. Nas doses acima das recomendadas os menores niveis de controle com os biotipos resistentes, aos 7 DAA, foram observados para o sethoxydim, fluazifop e fenoxaprop-p-ethyl.

Os valores de porcentagem de controle visual aos 14 DAA dos biotipos resistentes e suscetivel de $B$. plantaginea, submetidos a análise de variância estão apresentados na Tabela 5 . Em todas as doses e herbicidas avaliados verificou-se a maior sensibilidade do biotipo suscetivel, o qual expressou niveis de controle significativamente superiores.

Os herbicidas nas doses de campo recomendadas não foram eficazes no controle do crescimento das plantas, aos 14 DAA para os biotipos resistentes. Acima das doses recomendadas, os biotipos A e B apresentaram-se com controles equivalentes aos da população suscetivel, para o herbicida clethodim; e o biotipo B apresentou-se com controles equivalentes aos da população suscetivel para os herbicidas butroxydim, haloxyfop e propaquizafop, nas doses acima das recomendadas. Nas doses abaixo das recomendadas, $\mathrm{o}$ biotipo $\mathrm{A}$ apresentou maior tolerância aos herbicidas 
Tabela 4. Porcentagem de controle visual(1,2) aos 7 DAA(3) para biotipos de Brachiaria plantaginea, em casa-de-vegetação. Holambra/SP - 1998.

\begin{tabular}{|c|c|c|c|c|c|}
\hline DOSES(4) & HERBICIDAS & Biotipo A & Biotipo B & Biotipo S & MEDIAS \\
\hline \multirow{10}{*}{$\mathbf{O} \mathbf{D}$} & sethoxydim & 0,0 A a & 0,0 A a & $0,0 \mathrm{~A} \mathrm{a}$ & 0,0 \\
\hline & clethodim & $0,0 \mathrm{~A} \mathbf{a}$ & $0,0 \mathrm{~A}$ a & $0,0 \mathrm{~A} \mathrm{a}$ & 0,0 \\
\hline & butroxydim & $0,0 \mathrm{~A} \mathrm{a}$ & $0,0 \mathrm{~A} \mathbf{a}$ & $0,0 \mathrm{~A} \mathrm{a}$ & 0,0 \\
\hline & propaquizafop & 0,0 A a & 0,0 A a & $0,0 \mathrm{~A}$ a & 0,0 \\
\hline & diclofop-methyl & 0,0 A a & 0,0 A a & $0,0 \mathrm{~A}$ a & 0,0 \\
\hline & haloxyfop-methyl & $0,0 \mathrm{~A} \mathrm{a}$ & $0,0 \mathrm{~A}$ a & $0,0 \mathrm{~A}$ a & 0,0 \\
\hline & quizalofop-p-ethyl & $0,0 \mathrm{~A} \mathrm{a}$ & $0,0 \mathrm{~A}$ a & $0,0 \mathrm{~A} \mathrm{a}$ & 0,0 \\
\hline & fluazifop-p-butil & 0,0 A a & 0,0 A a & 0,0 A a & 0,0 \\
\hline & fenoxaprop-p-ethyl & $0,0 \mathrm{~A} \mathrm{a}$ & $0,0 \mathrm{~A} \mathbf{a}$ & $0,0 \mathrm{~A}$ a & 0,0 \\
\hline & MÉDIAS & 0,0 & 0,0 & 0,0 & \\
\hline \multirow{10}{*}{$1 / 16 D$} & sethoxydim & $1,3 \mathrm{~B} \quad \mathrm{c}$ & $1,9 \mathrm{~B}$ bcd & $46,2 \mathrm{~A} a b c$ & 10,6 \\
\hline & clethodim & $9,7 \mathrm{~B} \mathrm{ab}$ & $10,4 \mathrm{~B} \mathrm{ab}$ & $57,5 \mathrm{~A} \mathrm{a}$ & 23,1 \\
\hline & butroxydim & $13,7 \mathrm{~B} \mathrm{a}$ & $13,7 \mathrm{~B}$ a & $41,9 \mathrm{~A}$ abc & 21,7 \\
\hline & propaquizafop & 9,3 B abc & $2,8 \mathrm{~B}$ bcd & $27,1 \mathrm{~A} \quad \mathrm{c}$ & 11,3 \\
\hline & diclofop-methyl & $2,8 \mathrm{~B} \mathrm{~b}$ & $0,3 \mathrm{~B} \quad \mathrm{~cd}$ & $18,7 \mathrm{~A}$ & 5,0 \\
\hline & haloxyfop-methyl & $13,5 \mathrm{~B}$ a & $0,6 \mathrm{C} \quad \mathrm{cd}$ & $53,8 \mathrm{~A}$ a & 17,5 \\
\hline & quizalofop-p-ethyl & 4,6 B abc & $5,0 \mathrm{~B}$ abc & $34,6 \mathrm{~A}$ bcd . & 12,2 \\
\hline & fluazifop-p-butil & 4,6 B abc & $1,3 \mathrm{~B} \quad \mathrm{~cd}$ & $42,4 \mathrm{~A}$ abc & 11,5 \\
\hline & fenoxaprop-p-ethyl & $2,8 \mathrm{~B} \quad \mathrm{bc}$ & $0,0 \mathrm{C}$ & 42,9 A abc & 8,4 \\
\hline & MÉDIAS & 6,2 & 2,7 & 40,2 & \\
\hline \multirow{10}{*}{$1 / 4 \mathrm{D}$} & sethoxydim & $1,3 \mathrm{~B}$ & $1,3 \mathrm{~B} \quad \mathrm{~d}$ & $56,3 \mathrm{~A} \quad \mathrm{~b}$ & 12,3 \\
\hline & clethodim & $32,4 \mathrm{~B} \mathrm{a}$ & $10,6 \mathrm{C}$ abc & $71,5 \mathrm{~A} \mathrm{ab}$ & 36,5 \\
\hline & butroxydim & $27,1 \mathrm{~B} \mathrm{ab}$ & $15,0 \mathrm{~B} \mathrm{ab}$ & $73,9 \mathrm{~A} \mathrm{ab}$ & 37,6 \\
\hline & propaquizafop & $17,4 \mathrm{~B} \mathrm{abc}$ & $18,7 \mathrm{~B} \mathrm{ab}$ & $61,4 \mathrm{~A}$ ab & 31,2 \\
\hline & diclofop-methyl & $6,1 \mathrm{~B} \quad \mathrm{cde}$ & $3,7 \mathrm{~B} \quad \mathrm{~cd}$ & $27,7 \mathrm{~A} \quad \mathrm{c}$ & 10,7 \\
\hline & haloxyfop-methyl & $11,2 \mathrm{~B}$ & $13,5 \mathrm{~B}$ abc & $62,8 \mathrm{~A} \mathrm{ab}$ & 26,8 \\
\hline & quizalofop-p-ethyl & $5,0 \mathrm{C}$ & $19,9 \mathrm{~B} \mathrm{a}$ & $78,0 \mathrm{~A} \mathrm{a}$ & 31,0 \\
\hline & fluazifop-p-butil & $14,6 \mathrm{~B}$ bcd & $6,1 \mathrm{~B}$ bcd & $63,8 \mathrm{~A} \mathrm{ab}$ & 25,0 \\
\hline & fenoxaprop-p-ethyl & $0,3 \mathrm{~B}$ & $1,3 \mathrm{~B} \quad \mathrm{~d}$ & $75,1 \mathrm{~A} \mathrm{ab}$ & 15,6 \\
\hline & MEDIAS & 10,4 & 8,6 & 63,7 & \\
\hline \multirow{10}{*}{$1 \mathrm{D}$} & sethoxydim & $14,6 \mathrm{~B} \quad \mathrm{c}$ & $1,9 \mathrm{C} \quad \mathrm{b}$ & $71,3 \mathrm{~A} \mathrm{a}$ & 24,0 \\
\hline & clethodim & $53,0 \mathrm{~B}$ a & $43,6 \mathrm{~B}$ a & $75,2 \mathrm{~A} \mathrm{a}$ & 57,6 \\
\hline & butroxydim & $45,0 \mathrm{~B} \mathrm{ab}$ & $36,0 \mathrm{~B}$ a & $76,6 \mathrm{~A}$ a & 52,9 \\
\hline & propaquizafop & $29,5 \mathrm{~B}$ bc & $35,9 \mathrm{~B}$ a & $72,5 \mathrm{~A} \mathrm{a}$ & 46,0 \\
\hline & diclofop-methyl & $24,8 \mathrm{~B} \quad \mathrm{c}$ & $3,8 \mathrm{C} \quad \mathrm{b}$ & $48,7 \mathrm{~A} \quad \mathrm{~b}$ & 22,7 \\
\hline & haloxyfop-methyl & $21,0 \mathrm{~B}$ & $34,4 \mathrm{~B}$ a & $74,1 \mathrm{~A} \mathrm{a}$ & 42,8 \\
\hline & quizalofop-p-ethyl & $18,7 \mathrm{C}$ & $37,5 \mathrm{~B} \mathrm{a}$ & $79,0 \mathrm{~A}$ a & 44,8 \\
\hline & fluazifop-p-butil & $18,2 \mathrm{C}$ & $39,8 \mathrm{~B}$ a & $70,2 \mathrm{~A}$ a & 42,1 \\
\hline & fenoxaprop-p-ethyl & 19,9 B $\quad$ c & $4,4 \mathrm{C} \quad \mathrm{b}$ & $76,4 \mathrm{~A}$ a & 30,0 \\
\hline & MÉDIAS & 26,5 & 23,2 & 71,8 & \\
\hline
\end{tabular}


Continuação...

Tabela 4. Porcentagem de controle visual(1,2) aos 7 DAA(3) para biotipos de Brachiaria plantaginea, em casa-de-vegetação. Holambra/SP - 1998.

\begin{tabular}{|c|c|c|c|c|c|}
\hline DOSES(3) & HERBICIDAS & Biotipo A & Biotipo B & Biotipo S & $\bar{M} \overline{\text { MIAS }}$ \\
\hline \multirow{10}{*}{$4 \mathrm{D}$} & sethoxydim & $18,7 \mathrm{~B}$ & $8,6 \mathrm{~B}$ & $68,8 \mathrm{~A} \mathrm{a}$ & 29,5 \\
\hline & clethodim & $72,9 \mathrm{~A} \mathrm{a}$ & $72,7 \mathrm{~A}$ a & $82,6 \mathrm{~A} \mathrm{a}$ & 76,2 \\
\hline & butroxydim & $65,1 \mathrm{~A} \mathrm{a}$ & $40,0 \mathrm{~B} \quad \mathrm{~b}$ & $77,8 \mathrm{~A}$ a & 61,4 \\
\hline & propaquizafop & 34,9 B bcd & $36,1 \mathrm{~B}$ & $79,0 \mathrm{~A} \mathrm{a}$ & 50,5 \\
\hline & diclofop-methyl & $31,8 \mathrm{~B}$ bcd & $34,8 \mathrm{~B}$ bc & 68,9 A a & 45,1 \\
\hline & haloxyfop-methyl & $42,4 \mathrm{~B} \quad \mathrm{~b}$ & $45,0 \mathrm{~B} \quad \mathrm{~b}$ & $74,1 \mathrm{~A}$ a & 54,1 \\
\hline & quizalofop-p-ethyl & $37,4 \mathrm{~B}$ bc & 43,6 B $\quad b$ & $80,3 \mathrm{~A} \mathrm{a}$ & 54,5 \\
\hline & fluazifop-p-butil & $25,7 \mathrm{~B}$ bcd & $32,2 \mathrm{~B}$ & 72,9 A a & 43,4 \\
\hline & fenoxaprop-p-ethyl & $23,2 \mathrm{~B} \quad \mathrm{~cd}$ & 19,7 B $\quad$ cd & $83,2 \mathrm{~A} \mathrm{a}$ & 41,9 \\
\hline & $\begin{array}{r}\text { MÉDIAS } \\
\end{array}$ & 38,7 & 36,1 & 76,6 & \\
\hline \multirow{10}{*}{$16 \mathrm{D}$} & sethoxydim & $55,0 \mathrm{~B} \quad \mathrm{~cd}$ & $35,0 \mathrm{C} \quad \mathrm{cd}$ & $83,8 \mathrm{~A} \mathrm{a}$ & 58,9 \\
\hline & clethodim & 94,9 A a & 85,4 B & $75,2 \mathrm{~B} \mathrm{a}$ & 86,2 \\
\hline & butroxydim & $79,0 \mathrm{~A} \mathrm{~b}$ & $68,8 \mathrm{~A} \quad \mathrm{ab}$ & $80,0 \mathrm{~A} \mathrm{a}$ & 76,1 \\
\hline & propaquizafop & 55,0 B $\quad c d$ & $53,8 \mathrm{~B}$ bc & $81,4 \mathrm{~A} \mathrm{a}$ & 64,1 \\
\hline & diclofop-methyl & $52,5 \mathrm{~B}$ & $41,1 \mathrm{~B} \quad \mathrm{~cd}$ & $75,1 \mathrm{~A} \mathrm{a}$ & 56,6 \\
\hline & haloxyfop-methyl & $60,1 \mathrm{~B}$ & $67,6 \mathrm{AB}$ ab & 76,3 A a & 68,2 \\
\hline & quizalofop-p-ethyl & 39,9 B & $52,5 \mathrm{~B} \quad$ bc & $83,2 \mathrm{~A} \mathrm{a}$ & 59,5 \\
\hline & fluazifop-p-butil & $69,4 \mathrm{~B}$ & $32,4 \mathrm{C}$ & $86,5 \mathrm{~A} \mathrm{a}$ & 64,1 \\
\hline & fenoxaprop-p-ethyl & $39,9 \mathrm{~B}$ & 34,9 B & $86,5 \mathrm{~A} \mathrm{a}$ & 55,1 \\
\hline & MÉDIAS & 62,0 & 51,4 & 82,2 & \\
\hline \multirow{13}{*}{$64 D$} & sethoxydim & 75,2 B $\quad$ b & $46,2 \mathrm{C} \quad \mathrm{cd}$ & $87,8 \mathrm{~A} \mathrm{a}$ & 71,1 \\
\hline & clethodim & $90,0 \mathrm{AB}$ a & $80,1 \mathrm{~B}$ & 99,4 A a & 91,9 \\
\hline & butroxydim & $80,5 \mathrm{~B} \quad \mathrm{~b}$ & $72,5 \mathrm{~B} \quad \mathrm{ab}$ & 87,6 A a & 80,6 \\
\hline & propaquizafop & $62,7 \mathrm{~B}$ & $72,7 \mathrm{AB} \quad \mathrm{ab}$ & $80,5 \mathrm{~A} \mathrm{a}$ & 72,2 \\
\hline & diclofop-methyl & $66,4 \mathrm{~B}$ & $58,9 \mathrm{~B}$ bc & $84,0 \mathrm{~A} \mathrm{a}$ & 70,4 \\
\hline & haloxyfop-methyl & $78,9 \mathrm{~A}$ & $70,1 \mathrm{~A}$ & $80,3 \mathrm{~A} \mathrm{a}$ & 76,6 \\
\hline & quizalofop-p-ethyl & $70,2 \mathrm{~B}$ & $65,1 \mathrm{~B}$ & $90,7 \mathrm{~A} \mathrm{a}$ & 76,5 \\
\hline & fluazifop-p-butil & $76,6 \mathrm{~A}$ & $38,4 \mathrm{~B}$ & $85,8 \mathrm{~A} \mathrm{a}$ & 68,3 \\
\hline & fenoxaprop-p-ethyl & $42,5 \mathrm{C}$ & $60,1 \mathrm{~B} \quad$ bc & $85,0 \mathrm{~A} \mathrm{a}$ & 63,6 \\
\hline & MÉDIAS & 74,6 & 63,1 & 85,9 & \\
\hline & CV (\%) & & & & \\
\hline & $\mathrm{DMS}^{\mathrm{a}}(\mathbf{5 \%})$ & & & & \\
\hline & $\operatorname{DMS}^{\mathrm{b}}(5 \%)$ & & & & \\
\hline
\end{tabular}

(1) Escala percentual onde $0 \%$ equivale a nenhum controle e $100 \%$ equivale a controle total, comparados à testemunha sem herbicida,

(2) $\mathrm{Na}$ análise de variância os dados foram transformados para arc seno $\mathrm{V}$ x/ 100

(3) $\mathrm{DAA}=$ dias apóps aplicação dos herbicidas

(4) $\mathrm{D}=$ doses de campo recomendadas em $L$ ha $^{-1}$ (sethoxydim $=1,25$; clethodim $=0,45$; butroxydin $=250 \mathrm{~g} \mathrm{~kg}^{-1}$; propaquizafop $=1,25$; diciofop-methyl $=2,5$; haloxyfop-methyl $=$ 0,5; quizalofop-p-ethyl $=2,0$; fluazifop-p-butil $=2,0$; fenoxaprop-p-ethyl $=0,82$ )

$\operatorname{DMSa}^{(5 \%)}=$ Diferença minima significativa para comparação entre herbicidas, $\operatorname{DMS}^{b}(5 \%)=$ Diferença minima significativa para comparação entre biotipos, Médias seguidas por letras distintas, maiúsculas nas linhas e minúsculas nas colunas, diferem entre si a 5\% de significância, pelo teste de Tukey. 
Tabela 5. Porcentagem de controle visual $(1,2)$ aos $14 \mathrm{DAA}^{(3)}$ para biotipos de Brachiaria plantaginea, em casa-de-vegetação. Holambra/SP - 1998.

\begin{tabular}{|c|c|c|c|c|c|}
\hline DOSES(4) & HERBICIDAS & Biotipo A & Biotipo B & Biotipo S & MEDIAS \\
\hline \multirow[t]{2}{*}{ O D } & $\begin{array}{l}\text { sethoxydim } \\
\text { clethodim } \\
\text { butroxydim } \\
\text { propaquizafop } \\
\text { diclofop-methyl } \\
\text { haloxyfop-methyl } \\
\text { quizalofop-p-ethyl } \\
\text { fluazifop-p-butil } \\
\text { fenoxaprop-p-ethyl }\end{array}$ & $\begin{array}{l}0,0 \mathrm{~A} \mathrm{a} \\
0,0 \mathrm{~A} \mathrm{a} \\
0,0 \mathrm{~A} \mathrm{a} \\
0,0 \mathrm{~A} \mathrm{a} \\
0,0 \mathrm{~A} \mathrm{a} \\
0,0 \mathrm{~A} \mathrm{a} \\
0,0 \mathrm{~A} \mathrm{a} \\
0,0 \mathrm{~A} \mathrm{a} \\
0,0 \mathrm{~A} \mathrm{a}\end{array}$ & $\begin{array}{l}0,0 \mathrm{~A} \mathrm{a} \\
0,0 \mathrm{~A} \mathrm{a} \\
0,0 \mathrm{~A} \mathrm{a} \\
0,0 \mathrm{~A} \mathrm{a} \\
0,0 \mathrm{~A} \mathrm{a} \\
0,0 \mathrm{~A} \mathrm{a} \\
0,0 \mathrm{~A} \mathrm{a} \\
0,0 \mathrm{~A} \mathrm{a} \\
0,0 \mathrm{~A} \mathrm{a}\end{array}$ & $\begin{array}{l}0,0 \mathrm{~A} \mathrm{a} \\
0,0 \mathrm{~A} \mathrm{a} \\
0,0 \mathrm{~A} \mathrm{a} \\
0,0 \mathrm{~A} \mathrm{a} \\
0,0 \mathrm{~A} \mathrm{a} \\
0,0 \mathrm{~A} \mathrm{a} \\
0,0 \mathrm{~A} \mathrm{a} \\
0,0 \mathrm{~A} \mathrm{a} \\
0,0 \mathrm{~A} \mathrm{a}\end{array}$ & $\begin{array}{l}0,0 \\
0,0 \\
0,0 \\
0,0 \\
0,0 \\
0,0 \\
0,0 \\
0,0 \\
0,0 \\
\end{array}$ \\
\hline & MÉDIAS & 0,0 & 0,0 & 0,0 & \\
\hline \multirow[t]{2}{*}{$1 / 16 \mathrm{D}$} & $\begin{array}{l}\text { sethoxydim } \\
\text { clethodim } \\
\text { butroxydim } \\
\text { propaquizafop } \\
\text { diclofop-methyl } \\
\text { haloxyfop-methyl } \\
\text { quizalofop-p-ethyl } \\
\text { fluazifop-p-butil } \\
\text { fenoxaprop-p-ethyl }\end{array}$ & $\begin{array}{l}10,8 \mathrm{~B} \mathrm{a} \\
28,7 \mathrm{~B} \mathrm{a} \\
23,6 \mathrm{~B} \mathrm{a} \\
20,7 \mathrm{~B} \mathrm{a} \\
18,6 \mathrm{~B} \mathrm{a} \\
16,0 \mathrm{~B} \mathrm{a} \\
26,1 \mathrm{~B} \mathrm{a} \\
10,8 \mathrm{~B} \mathrm{a} \\
10,7 \mathrm{~B} \mathrm{a} \\
\end{array}$ & $\begin{array}{r}14,8 \mathrm{~B} \mathrm{ab} \\
19,6 \mathrm{~B} \mathrm{a} \\
24,0 \mathrm{~B} \mathrm{ab} \\
13,5 \mathrm{~B} \mathrm{ab} \\
9,7 \mathrm{~B} \mathrm{ab} \\
9,7 \mathrm{~B} \mathrm{ab} \\
15,7 \mathrm{~B} \mathrm{ab} \\
18,8 \mathrm{~B} \mathrm{ab} \\
7,3 \mathrm{~B} \mathrm{~b}\end{array}$ & $\begin{array}{l}60,5 \mathrm{~A} \mathrm{a} \\
72,9 \mathrm{~A} \mathrm{a} \\
78,0 \mathrm{~A} \mathrm{a} \\
62,7 \mathrm{~A} \mathrm{~b} \\
35,6 \mathrm{~A} \mathrm{a} \\
66,4 \mathrm{~A} \mathrm{ab} \\
57,6 \mathrm{~A} \mathrm{a} \\
71,1 \mathrm{~A} \mathrm{a} \\
60,6 \mathrm{~A} \mathrm{a} \\
\end{array}$ & $\begin{array}{l}26,5 \\
39,7 \\
41,6 \\
30,7 \\
20,3 \\
28,2 \\
32,1 \\
31,5 \\
23,0 \\
\end{array}$ \\
\hline & MEDIAS & 18,0 & 14,4 & 63,1 & \\
\hline \multirow[t]{2}{*}{$1 / 4 \mathrm{D}$} & $\begin{array}{l}\text { sethoxydim } \\
\text { clethodim } \\
\text { butroxydim } \\
\text { propaquizafop } \\
\text { diclofop-methyl } \\
\text { haloxyfop-methyl } \\
\text { quizalofop-p-ethyl } \\
\text { fluazifop-p-butil } \\
\text { fenoxaprop-p-ethyl }\end{array}$ & $\begin{array}{l}16,0 \mathrm{~B} \quad \mathrm{c} \\
47,5 \mathrm{~B} \mathrm{a} \\
41,2 \mathrm{~B} \mathrm{ab} \\
27,1 \mathrm{~B} \text { abc } \\
17,9 \mathrm{~B} \quad \mathrm{c} \\
22,4 \mathrm{~B} \text { bc } \\
22,2 \mathrm{~B} \text { bc } \\
24,5 \mathrm{~B} \text { bc } \\
16,4 \mathrm{~B} \quad \mathrm{c} \\
\end{array}$ & $\begin{array}{l}12,4 \mathrm{~B} \mathrm{c} \\
55,1 \mathrm{~B} \mathrm{a} \\
21,8 \mathrm{C} \mathrm{bc} \\
32,1 \mathrm{~B} \mathrm{ab} \\
19,5 \mathrm{~B} \mathrm{bc} \\
37,3 \mathrm{~B} \mathrm{ab} \\
48,8 \mathrm{~B} \mathrm{a} \\
18,6 \mathrm{~B} \mathrm{bc} \\
7,3 \mathrm{~B} \mathrm{c} \\
\end{array}$ & $\begin{array}{l}90,6 \mathrm{~A} \mathrm{a} \\
91,5 \mathrm{~A} \mathrm{a} \\
96,3 \mathrm{~A} \mathrm{a} \\
93,3 \mathrm{~A} \mathrm{a} \\
69,4 \mathrm{~A} \mathrm{~b} \\
97,9 \mathrm{~A} \mathrm{a} \\
97,6 \mathrm{~A} \mathrm{a} \\
90,0 \mathrm{~A} \mathrm{a} \\
88,6 \mathrm{~A} \mathrm{a} \\
\end{array}$ & $\begin{array}{l}39,2 \\
66,9 \\
56,8 \\
53,5 \\
34,4 \\
57,3 \\
60,7 \\
45,2 \\
35,6 \\
\end{array}$ \\
\hline & MEDIAS & 25,6 & 26,8 & 91,8 & \\
\hline \multirow[t]{2}{*}{1 D } & $\begin{array}{l}\text { sethoxydim } \\
\text { clethodim } \\
\text { butroxydim } \\
\text { propaquizafop } \\
\text { diclofop-methyl } \\
\text { haloxyfop-methyl } \\
\text { quizalofop-p-ethyl } \\
\text { fluazifop-p-butil } \\
\text { fenoxaprop-p-ethyl }\end{array}$ & $\begin{array}{l}32,4 \mathrm{~B} \text { b } \\
77,8 \mathrm{~B} \text { a } \\
65,4 \mathrm{~B} \text { a } \\
39,4 \mathrm{~B} \text { b } \\
30,1 \mathrm{~B} \\
38,7 \mathrm{C} \\
32,4 \mathrm{C} \\
34,7 \mathrm{~B} \\
37,3 \mathrm{~B} \\
\end{array}$ & $\begin{array}{l}13,5 \mathrm{~B} \quad \mathrm{e} \\
76,9 \mathrm{~B} \mathrm{a} \\
75,6 \mathrm{~B} \mathrm{ab} \\
50,0 \mathrm{~B} \quad \mathrm{~cd} \\
18,2 \mathrm{~B} \quad \mathrm{e} \\
66,8 \mathrm{~B} \text { abc } \\
53,7 \mathrm{~B} \quad \mathrm{bcd} \\
32,4 \mathrm{~B} \quad \mathrm{de} \\
22,4 \mathrm{~B} \quad \mathrm{e}\end{array}$ & $\begin{array}{c}95,3 \mathrm{~A} \mathrm{ab} \\
99,7 \mathrm{~A} \mathrm{ab} \\
99,7 \mathrm{~A} \mathrm{ab} \\
100,0 \mathrm{~A} \mathrm{a} \\
79,2 \mathrm{~A} \mathrm{c} \\
99,7 \mathrm{~A} \mathrm{ab} \\
99,7 \mathrm{~A} \mathrm{ab} \\
92,5 \mathrm{~A} \mathrm{bc} \\
97,1 \mathrm{~A} \mathrm{ab} \\
\end{array}$ & $\begin{array}{l}49,3 \\
88,3 \\
84,8 \\
71,9 \\
42,4 \\
75,0 \\
69,1 \\
55,8 \\
56,4 \\
\end{array}$ \\
\hline & MEDIAS & 43,3 & 45,8 & 97,7 & \\
\hline
\end{tabular}


Continuação...

Tabela 5. Porcentagem de controle visual $(1,2)$ aos $14 \mathrm{DAA}^{(3)}$ para biotipos de Brachiaria plantaginea, em casa-de-vegetação. Holambra/SP - 1998.

\begin{tabular}{|c|c|c|c|c|c|}
\hline DOSES(3) & HERBICIDAS & Biotipo A & Biotipo B & Biotipo S & MÉDIAS \\
\hline \multirow{9}{*}{$4 D$} & sethoxydim & $28,7 \mathrm{~B} \quad \mathrm{~b}$ & $14,8 \mathrm{~B}$ & $99,3 \mathrm{~A} \mathrm{a}$ & 53,2 \\
\hline & clethodim & $90,7 \mathrm{~B} \mathrm{a}$ & $97,4 \mathrm{AB}$ a & $100,0 \mathrm{~A} \mathrm{a}$ & 97,6 \\
\hline & butroxydim & $75,2 \mathrm{~B} \mathrm{a}$ & $65,1 \mathrm{~B}$ bc & $100,0 \mathrm{~A} \mathrm{a}$ & 85,9 \\
\hline & propaquizafop & 50,0 B b & $64,0 \mathrm{~B}$ & $100,0 \mathrm{~A} \mathrm{a}$ & 79,0 \\
\hline & diclofop-methyl & $32,0 \mathrm{C} \quad \mathrm{b}$ & 55,5 B & $100,0 \mathrm{~A} \mathrm{a}$ & 66,2 \\
\hline & haloxyfop-methyl & $43,7 \mathrm{C} \quad \mathrm{b}$ & $75,1 \mathrm{~B}$ & $100,0 \mathrm{~A} \mathrm{a}$ & 80,5 \\
\hline & quizalofop-p-ethyl & $43,7 \mathrm{~B} \quad \mathrm{~b}$ & 58,1 B & $100,0 \mathrm{~A} \mathrm{a}$ & 75,5 \\
\hline & fluazifop-p-butil & $38,7 \mathrm{C} \quad \mathrm{b}$ & $58,8 \mathrm{~B}$ & $100,0 \mathrm{~A} \mathrm{a}$ & 74,3 \\
\hline & fenoxaprop-p-ethyl & $33,0 \mathrm{~B} \quad \mathrm{~b}$ & $42,5 \mathrm{~B} \quad \mathrm{c}$ & $100,0 \mathrm{~A} \mathrm{a}$ & 67,5 \\
\hline & MÉDIAS & 49,2 & 60,4 & 99,9 & \\
\hline \multirow{10}{*}{$16 \mathrm{D}$} & sethoxydim & $48,7 \mathrm{~B}$ & $28,6 \mathrm{C}$ & $100,0 \mathrm{~A} \mathrm{a}$ & 68,0 \\
\hline & clethodim & $99,3 \mathrm{~A}$ a & $100,0 \mathrm{~A} \mathrm{a}$ & $100,0 \mathrm{~A} \mathrm{a}$ & 99,9 \\
\hline & butroxydim & $90,6 \mathrm{~B} \mathrm{ab}$ & $99,7 \mathrm{~A} \mathrm{a}$ & $100,0 \mathrm{~A} \mathrm{a}$ & 98,5 \\
\hline & propaquizafop & $67,6 \mathrm{~B} \quad$ cde & 79,3 B bc & $100,0 \mathrm{~A} \mathrm{a}$ & 87,3 \\
\hline & diclofop-methyl & $47,4 \mathrm{C}$ & 72,9 B bc & $97,4 \mathrm{~A} \mathrm{a}$ & 76,5 \\
\hline & haloxyfop-methyl & $70,2 \mathrm{~B}$ & 98,7 A a & $100,0 \mathrm{~A} \mathrm{a}$ & 94,8 \\
\hline & quizalofop-p-ethyl & 70,6 B cd & 85,1 B $\quad$ b & $100,0 \mathrm{~A} \mathrm{a}$ & 89,9 \\
\hline & fluazifop-p-butil & 73,9 B bc & 63,9 B $\quad$ c & $100,0 \mathrm{~A} \mathrm{a}$ & 85,3 \\
\hline & fenoxaprop-p-ethyl & $48,7 \mathrm{C} \quad \mathrm{de}$ & $67,6 \mathrm{~B}$ bc & $100,0 \mathrm{~A} \mathrm{a}$ & 79,7 \\
\hline & MÉDIAS & 71,3 & 82,9 & 99,7 & \\
\hline \multirow{13}{*}{$64 D$} & sethoxydim & $53,7 \mathrm{~B} \quad \mathrm{c}$ & $67,6 \mathrm{~B}$ & $100,0 \mathrm{~A} \mathrm{a}$ & 81,0 \\
\hline & clethodim & $100,0 \mathrm{~A} \mathrm{a}$ & $99,7 \mathrm{~A} \quad \mathrm{ab}$ & $100,0 \mathrm{~A} \mathrm{a}$ & 99,9 \\
\hline & butroxydim & 96,2 B a & $99,3 \mathrm{AB}$ abc & $100,0 \mathrm{~A} \mathrm{a}$ & 99,2 \\
\hline & propaquizafop & $78,2 \mathrm{~B} \quad \mathrm{~b}$ & $100,0 \mathrm{~A}$ a & $100,0 \mathrm{~A} \mathrm{a}$ & 97,4 \\
\hline & diclofop-methyl & $79,1 \mathrm{~B} \quad$ b & $79,0 \mathrm{~B}$ & $99,7 \mathrm{~A} \mathrm{a}$ & 89,2 \\
\hline & haloxyfop-methyl & $94,5 \mathrm{~B} \mathrm{a}$ & 96,3 B & $100,0 \mathrm{~A} \mathrm{a}$ & 98,0 \\
\hline & quizalofop-p-ethyl & $77,7 \mathrm{C} \quad$ b & $92,5 \mathrm{~B}$ & $100,0 \mathrm{~A} \mathrm{a}$ & 93,6 \\
\hline & fluazifop-p-butil & $71,7 \mathrm{~B}$ bc & 72,9 B & f $100,0 \mathrm{Aa}$ & 87,0 \\
\hline & fenoxaprop-p-ethyl & $75,7 \mathrm{C}$ bc & $90,6 \mathrm{~B}$ & $100,0 \mathrm{~A} \mathrm{a}$ & 92,6 \\
\hline & MËDIAS & 90,0 & 92,2 & 99,9 & \\
\hline & CV (\%) & & & & \\
\hline & $\mathrm{DMS}^{\mathrm{a}}(5 \%)$ & & & & \\
\hline & $\operatorname{DMS}^{\mathrm{b}}(5 \%)$ & & & & \\
\hline
\end{tabular}

(1) Escala percentual onde $0 \%$ equivale a nenhum controle e $100 \%$ equivale a controle total, comparados à testemunha sem herbicida.

(2) $\mathrm{Na}$ análise de variância os dados foram transformados para arc seno $V \mathrm{x} / 100$

(3) DAA = dias apóps aplicação dos herbicidas

(4) $\mathrm{D}=$ doses de campo recomendadas em $\mathrm{L}$ ha-1 (sethoxydim $=1,25$; clethodim $=0,45$;

butroxydim $=250 \mathrm{~g} \mathrm{~kg}^{-1} ;$ propaquizafop $=1,25$; diclofop-methyl $=2,5$; haloxyfop-methyl $=$

0,5 ; quizalofop-p-ethyl $=2,0$; fluazifop-p-butil $=2,0$; fenoxaprop-p-ethyl $=0,82$ )

DMSa $(5 \%)=$ Diferença minima significativa para comparação entre herbicidas.

$\operatorname{DMS}^{b}(5 \%)=$ Diferença minima significativa para comparação entre biotipos.

Médias seguidas por letras distintas, maiúsculas nas linhas e minúsculas nas colunas, diferem entre si a 5\% de significância, pelo teste de Tukey. 
sethoxydim, diclofop, e fenoxaprop, nas doses $1 / 4$ da recomendada; e o biotipo $\mathrm{B}$ apresentou maior tolerância aos herbicidas sethoxydim e fenoxaprop, nas doses $1 / 4$ da recomendada. Nas doses acima das doses recomendadas, os menores niveis de controle com os biotipos resistentes, aos 14 DAA, foram observados para o biotipo A com diclofop na dose 16D, e com sethoxydim na dose 64D. Para o biotipo B, os menores niveis de controle acima das doses recomendadas foram verificados com sethoxydim nas doses 16D e 64D. Foram verificados niveis de controle equivalentes aos obtidos com o biotipo $\mathrm{S}$, nos seguintes tratamentos: biotipo B na dose $4 \mathrm{D}$ com clethodim; biotipos A e B na dose 16D com clethodim; biotipo $B$ na dose 16D para clethodim, butroxydim e haloxyfop; biotipos A e B na dose 64D com clethodim e biotipo B na dose 64D para clethodim, butroxydim e propaquizafop.

Na avaliação da fitomassa obtida aos 15 DAA (Tabela 6) foram verificadas diferenças significativas entre herbicidas e doses, para cada biotipo avaliado, sendo também significativas as suas diferenças encontradas entre os biotipos (vide Anexo - Tabela A2).

Embora tenha ocorrido redução na produção de fitomassa, em alguns ratamentos com altas doses, as plantas não chegaram a morrer e, em muitos casos, foram apenas sensivelmente injuriadas. A colheita das parcelas, realizada aos 15 dias após a aplicação dos herbicidas, dá uma indicação da provável recuperação das plantas provenientes destes tratamentos.

A comparação do efeito das doses sobre a produção de fitomassa mostra que os tratamentos afetaram significativamente o biotipo suscetivel.

Os biotipos resistentes, tanto nas doses abaixo, como acima das recomendadas, apresentaram maior tolerância ao herbicida sethoxydim. Nas doses acima das recomendadas, apresentaram maior tolerância ao herbicida sethoxydim.

Os dados da porcentagem de controle visual aos 14 DAA foram submetidos à análise de regressão não linear, através do modelo proposto por Seefeldt et al., (1995), sendo as curvas de dose-resposta da porcentagem de controle estão apresentadas nas Figuras 1 a 9. 
Tabela 6. Fitomassa (g) recém colhida aos $15 \mathrm{DAA}^{(1)}$ de biotipos de Brachiaria plantaginea, em casa-de-vegetação. Holambra/SP - 1998.

\begin{tabular}{|c|c|c|c|c|c|}
\hline DOSES(2) & HERBICIDAS & Biotipo A & Biotipo B & Biotipo $\mathbf{S}$ & MEDIAS \\
\hline \multirow{10}{*}{$\mathbf{O} \mathbf{D}$} & sethoxydim & $20,2 \mathrm{~B} \mathrm{a}$ & $34,9 \mathrm{~A} \mathrm{a}$ & $28,6 \mathrm{~A} \mathrm{a}$ & 27,6 \\
\hline & clethodim & $24,4 \mathrm{~B}$ a & $38,0 \mathrm{~A}$ a & $34,2 \mathrm{~A}$ a & 31,9 \\
\hline & butroxydim & $19,2 \mathrm{~B}$ a & $37,6 \mathrm{~A} \mathbf{a}$ & $33,7 \mathrm{~A}$ a & 29,6 \\
\hline & propaquizafop & $20,3 \mathrm{~B}$ a & $34,2 \mathrm{~A} \mathrm{a}$ & 29,9 A a & 27,8 \\
\hline & diclofop-methyl & $18,5 \mathrm{~B}$ a & 37,4 A a & $33,2 \mathrm{~A}$ a & 29,1 \\
\hline & haloxyfop-methyl & $21,1 \mathrm{~B}$ a & $31,0 \mathrm{~A} \mathrm{a}$ & $32,5 \mathrm{~A}$ a & 27,9 \\
\hline & quizalofop-p-ethyl & $22,8 \mathrm{~B}$ a & $35,2 \mathrm{~A} \mathrm{a}$ & $32,9 \mathrm{~A}$ a & 30,0 \\
\hline & fluazifop-p-butil & $19,6 \mathrm{~B} \mathrm{a}$ & $32,7 \mathrm{~A}$ a & $32,0 \mathrm{~A}$ a & 27,7 \\
\hline & fenoxaprop-p-ethyl & $24,4 \mathrm{~B} \mathrm{a}$ & 36,9 A a & $36,5 \mathrm{~A} \mathrm{a}$ & 32,3 \\
\hline & MEDIAS & 21,1 & 35,3 & 32,6 & \\
\hline \multirow{10}{*}{$1 / 16$} & sethoxydim & $21,5 \mathrm{~B}$ abc & $31,6 \mathrm{~A} \mathrm{ab}$ & $11,1 \mathrm{C}$ & 20,5 \\
\hline & clethodim & $13,6 \mathrm{~B} \quad \mathrm{c}$ & $31,0 \mathrm{~A} \mathrm{ab}$ & $4,8 \mathrm{C}$ & 14,6 \\
\hline & butroxydim & $21,6 \mathrm{~A}$ abc & 26,4 A b & 4,5 B & 15,7 \\
\hline & propaquizafop & $17,6 \mathrm{~B}$ bc & $32,1 \mathrm{~A} \mathrm{ab}$ & $13,3 \mathrm{~B} \quad \mathrm{~b}$ & 20,2 \\
\hline & diclofop-methyl & $21,4 \mathrm{~B}$ abc & $37,9 \mathrm{~A} \mathrm{ab}$ & $26,4 \mathrm{AB} a$ & 27,3 \\
\hline & haloxyfop-methyl & $26,3 \mathrm{~A} \mathrm{ab}$ & $35,3 \mathrm{~A} \mathrm{ab}$ & $8,2 \mathrm{~B} \quad \mathrm{bc}$ & 21,6 \\
\hline & quizalofop-p-ethyl & $21,2 \mathrm{~B}$ abc & $35,9 \mathrm{~A} \mathrm{ab}$ & $13,7 \mathrm{C}$ & 22,7 \\
\hline & fluazifop-p-butil & $28,2 \mathrm{~A}$ a & $35,4 \mathrm{~A}$ a & $4,8 \mathrm{~B}$ & 20,1 \\
\hline & fenoxaprop-p-ethyl & $24,2 \mathrm{~B} \mathrm{ab}$ & $38,8 \mathrm{~A} \mathrm{ab}$ & $14,4 \mathrm{C} \quad \mathrm{b}$ & 24,8 \\
\hline & MEDIAS & 21,5 & 33,4 & 10,4 & \\
\hline \multirow{10}{*}{$1 / 4 \mathrm{D}$} & sethoxydim & $23,9 \mathrm{~A} \mathrm{a}$ & $32,5 \mathrm{~A}$ abc & $3,7 \mathrm{~B} \mathrm{ab}$ & 17,4 \\
\hline & clethodim & $13,8 \mathrm{~B} \quad \mathrm{~b}$ & $21,1 \mathrm{~A} \quad \mathrm{~d}$ & $3,4 \mathrm{C} \mathrm{ab}$ & 11,4 \\
\hline & butroxydim & $13,6 \mathrm{~B} \quad \mathrm{~b}$ & 28,5 A abcd & $2,7 \mathrm{C} \quad \mathrm{b}$ & 12,6 \\
\hline & propaquizafop & $15,2 \mathrm{~B} \mathrm{ab}$ & $22,5 \mathrm{~A}$ bcd & $3,4 \mathrm{C} \mathrm{ab}$ & 12,2 \\
\hline & diclofop-methyl & $22,0 \mathrm{~A} \mathrm{ab}$ & 29,0 A abcd & $8,0 \mathrm{~B}$ a & 18,5 \\
\hline & haloxyfop-methyl & $20,4 \mathrm{~A} \mathrm{ab}$ & 23,2 A bcd & $3,7 \mathrm{~B} \mathrm{ab}$ & 14,1 \\
\hline & quizalofop-p-ethyl & $21,8 \mathrm{~A} \mathrm{ab}$ & $22,0 \mathrm{~A}$ cd & $2,7 \mathrm{~B} \quad \mathrm{~b}$ & 13,5 \\
\hline & fluazifop-p-butil & $22,7 \mathrm{~B} \mathrm{ab}$ & $33,9 \mathrm{~A} \mathrm{ab}$ & $2,5 \mathrm{C} \quad \mathrm{b}$ & 16,5 \\
\hline & fenoxaprop-p-ethyl & $19,2 \mathrm{~B} \mathrm{ab}$ & $39,5 \mathrm{~A} \mathrm{a}$ & $3,8 \mathrm{C} \mathrm{ab}$ & 17,7 \\
\hline & MEDIAS & 19,0 & 27,7 & 3,7 & \\
\hline \multirow{9}{*}{$1 \mathbf{D}$} & sethoxydim & $16,6 \mathrm{~B} \mathrm{a}$ & $32,0 \mathrm{~A}$ a & $2,4 \mathrm{C} \quad \mathrm{b}$ & 14,1 \\
\hline & clethodim & $7,8 \mathrm{~A}$ bc & $5,9 \mathrm{AB}$ & $3,0 \mathrm{~B}$ & 5,4 \\
\hline & butroxydim & $7,0 \mathrm{~A} \quad \mathrm{c}$ & $6,2 \mathrm{AB} \quad \mathrm{c}$ & $2,3 \mathrm{~B}$ & 4,9 \\
\hline & propaquizafop & $14,2 \mathrm{~A} \mathrm{ab}$ & 17,4 A $\ldots$ & $2,1 \mathrm{~B} \quad \mathrm{~b}$ & 9,8 \\
\hline & diclofop-methyl & $23,4 \mathrm{~A} \mathrm{a}$ & $31,4 \mathrm{~A}$ a & $9,3 \mathrm{~B}$ a & 20,2 \\
\hline & haloxyfop-methyl & 16,9 A a & $6,6 \mathrm{~B}$ & $2,9 \mathrm{C} \quad \mathrm{b}$ & 7,8 \\
\hline & quizalofop-p-ethyl & $18,4 \mathrm{~A} \mathrm{a}$ & $15,8 \mathrm{~A} \quad \mathrm{~b}$ & $2,3 \mathrm{~B} \quad \mathrm{~b}$ & 10,6 \\
\hline & fluazifop-p-butil & $18,7 \mathrm{~B}$ a & $30,4 \mathrm{~A}$ & $3,1 \mathrm{C} \quad \mathrm{b}$ & 15,0 \\
\hline & fenoxaprop-p-ethyl & $19,4 \mathrm{~B} \mathrm{a}$ & 37,3 A a & $2,4 \mathrm{C} \quad \mathrm{b}$ & 16,3 \\
\hline
\end{tabular}


Continuação...

Tabela 6. Fitomassa (g) recém colhida aos $15 \mathrm{DAA}(1)$ de biotipos de Brachiaria plantaginea, em casa-de-vegetaçāo. Holambra/SP - 1998.

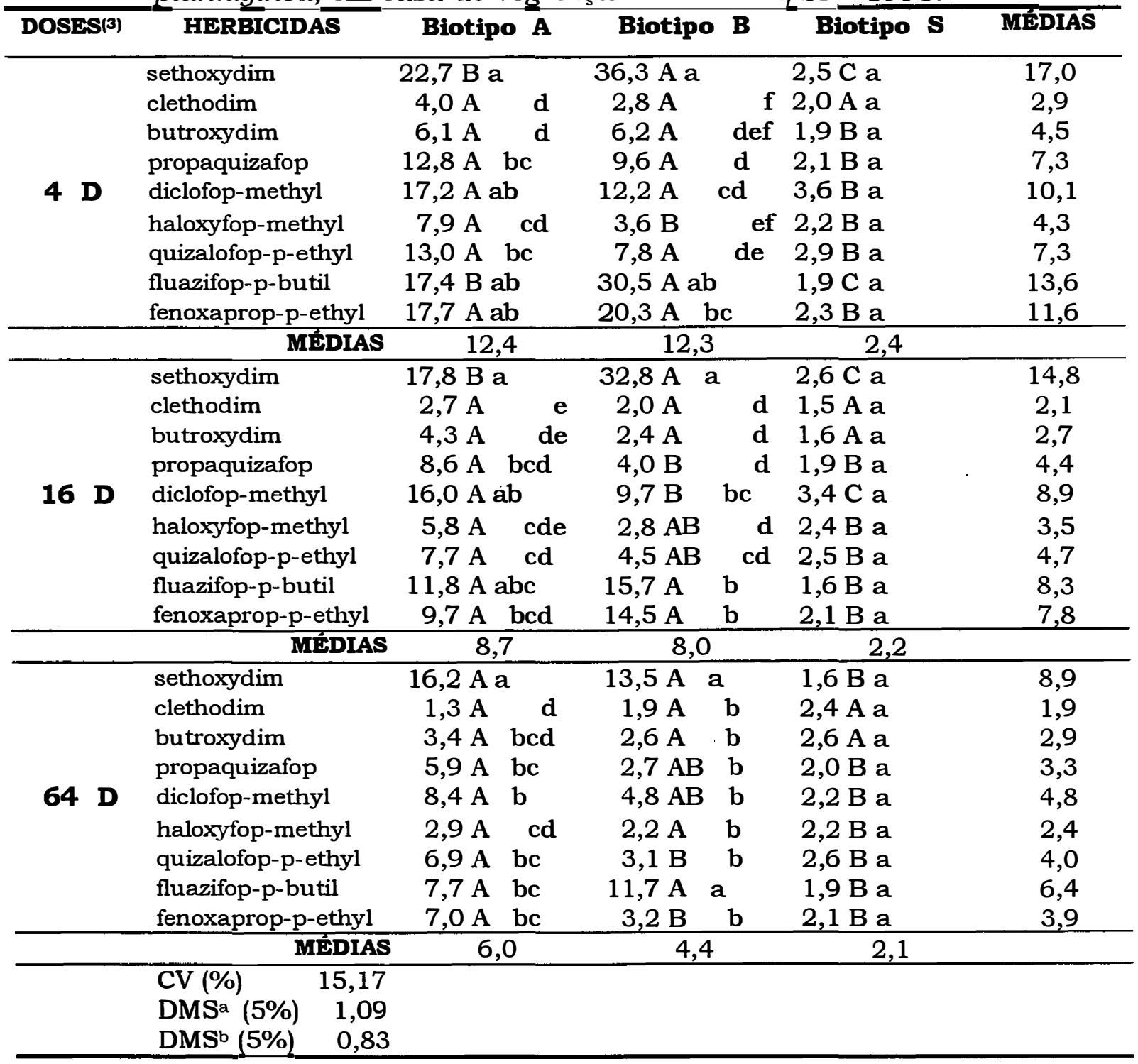

(1) DAA = dias apóps aplicação dos herbicidas

(2) $\mathrm{D}=$ doses de campo recomendadas em $\mathrm{L}$ ha-1 (sethoxydim $=1,25$; clethodim $=0,45$; butroxydim $=250 \mathrm{~g} \mathrm{~kg}^{-1}$; propaquizafop $=1,25$; diclofop-methyl $=2,5$; haloxyfop-methyl $=$ 0,5 ; quizalofop-p-ethyl $=2,0$; fluazifop-p-butil $=2,0$; fenoxaprop-p-ethyl $=0,82$ )

$\operatorname{DMSa}(5 \%)=$ Diferença minima significativa para comparação entre herbicidas.

Dìiso $(5 \%)=$ Diferença minima significativa para comparação entre bioitipos.

Médias seguidas por letras distintas, maiúsculas nas linhas e minúsculas nas colunas, diferem entre si a 5\% de significância, pelo teste de Tukey. 
Para todos herbicidas estudados, a curva de dose-resposta do biotipo suscetivel enconntra-se sempre na posiçāo superior do gráfico, e a dos biotipos resistentes abaixo, indicando menor eficiência de controle desses pelos herbicidas inibidores da ACCase, mesmo nas doses acima das recomendadas (Figura 1 a 9).

O coeficiente de declividade da reta biologicamente reflete a taxa de reduçāo nos niveis de controle em funçāo do aumento logarítmico da dose do herbicida (Streibig et al., 1995) (Tabela 7).

A resposta da fitomassa aos tratamentos nāo foi possivel de ser avaliada utilizando-se o modelo log-logístico, devido à grande dispersāo dos dados. Por isso, a estimativa do GR5o para a variável fitomassa, foi realizada através de um modelo exponencial (Tabela 8).

As Figuras 10 a 18 apresentam a produçāo de fitomassa recémcolhida pelos biotipos resistentes e suscetivel de $B$. plantaginea, quando tratados com herbicidas CHD e APP, com as médias ajustadas segundo um modelo exponencial. O biotipo suscetivel apresenta uma queda acentuada na produçāo de fitomassa, mesmo nas doses abaixo da recomendada, enquanto as curvas correspondentes à resposta dos biótipos resistentes posicionam-se sempre acima, no gráfico, indicando um menor efeito dos herbicidas na produçāo de fitomassa. As curvas obedecem ao mesmo padrāo encontrados para a variável porcentagem de controle, uma vez que os biotipos resistentes nāo foram controlados satisfatoriamente pelos herbicidas inibidores da ACCase, independente do grupo químico a que pertenciam.

Em todas as figuras observa-se que o biotipo A apresenta uma produçāo de fitomassa inicial nas testemunhas (sem herbicidas) e em algumas doses baixas, menor que a fitomassa produzida pelo biotipo suscetivel. Isto ocorreu por causa da diferença nas condições de germinaçāo encontradas entre as amostras dos biotipos trabalhados. O biotipo A apresentou menor velocidade de germinação e, conseqüentemente, menor produçāo de fitomassa por ocasiāo da aplicaçāo dos herbicidas. 
Tabela 7. Parâmetros estimados para a variável porcentagem de controle visual aos $14 \mathrm{DAA}^{(1)}$ e erros padrões assintóticos, para elaboraçāo de curvas de dose-resposta de herbicidas inibidores da ACCase a biotipos de Brachiaria plantaginea, segundo modelo log-logistico(2).

\begin{tabular}{|c|c|c|c|c|}
\hline HERBICIDAS & $\begin{array}{l}\text { PARÂ- } \\
\text { METROS }\end{array}$ & Biotipo A & Biotipo B & Biotipo $\mathbf{S}$ \\
\hline \multirow[t]{2}{*}{ sethoxydim } & $\mathbf{b}$ & $0,31 \pm 0,04$ & $0,65 \pm 0,07$ & $0,98 \pm 0,19$ \\
\hline & GR50 & $31,34 \pm 9,80$ & $34,90 \pm 5,74$ & $0,04 \pm 0,01$ \\
\hline \multirow[t]{2}{*}{ clethodim } & $\mathbf{b}$ & $0,77 \pm 0,07$ & $0,93 \pm 0,08$ & $0,21 \pm 0,22$ \\
\hline & GR50 & $0,24 \pm 0,03$ & $0,24 \pm 0,02$ & $0,02 \pm 0,01$ \\
\hline \multirow[t]{2}{*}{ butroxydim } & $\mathbf{b}$ & $0,57 \pm 0,06$ & $0,69 \pm 0,08$ & $1,26 \pm 0,65$ \\
\hline & $\mathbf{G R}_{\mathbf{5 0}}$ & $0,44 \pm 0,08$ & $0,58 \pm 0,09$ & $0,03 \pm 0,01$ \\
\hline \multirow[t]{2}{*}{ propaquizafop } & $\mathbf{b}$ & $0,38 \pm 0,04$ & $0,57 \pm 0,05$ & $1,14 \pm 0,28$ \\
\hline & $\mathbf{G R}_{\mathbf{5 0}}$ & $2,88 \pm 0,59$ & $1,13 \pm 0,18$ & $0,04 \pm 0,01$ \\
\hline \multirow[t]{2}{*}{ diclofop-methyl } & $\mathbf{b}$ & $0,39 \pm 0,06$ & $0,59 \pm 0,08$ & $0,66 \pm 0,12$ \\
\hline & $\mathbf{G R}_{\mathbf{5 0}}$ & $10,44 \pm 3,40$ & $4,21 \pm 0,96$ & $0,12 \pm 0,03$ \\
\hline \multirow[t]{2}{*}{ haloxyfop-methyl } & b & $0,52 \pm 0,05$ & $0,78 \pm 0,08$ & $1,32 \pm 0,40$ \\
\hline & GR50 & $3,01 \pm 0,49$ & $0,56 \pm 0,07$ & $0,04 \pm 0,01$ \\
\hline \multirow[t]{2}{*}{ quizalofop-p-ethyl } & b & $0,39 \pm 0,05$ & $0,43 \pm 0,05$ & $1,88 \pm 0,75$ \\
\hline & GR50 & $3,79 \pm 0,96$ & $0,81 \pm 0,19$ & $0,05 \pm 0,01$ \\
\hline \multirow[t]{2}{*}{ fluazifop-p-butil } & b & $0,44 \pm 0,04$ & $0,41 \pm 0,04$ & $0,73 \pm 0,20$ \\
\hline & GR50 & $4,74 \pm 0,89$ & $3,88 \pm 0,76$ & $0,02 \pm 0,01$ \\
\hline \multirow[t]{2}{*}{ fenoxaprop-p-ethyl } & $\mathbf{b}$ & $0,40 \pm 0,04$ & $0,74 \pm 0,07$ & $1,02 \pm 0,23$ \\
\hline & GR50 & $9,91 \pm 2,19$ & $5,71 \pm 0,80$ & $0,04 \pm 0,01$ \\
\hline
\end{tabular}

(1) DAA = dias após aplicação dos herbicidas

(2) Equaçāo do modelo log-logistico utilizado: $\boldsymbol{y}=\{$ (D-C) $/$ [ $1+\exp ($ b (log GRso - log dose) $\}+C$

Nota: Os parâmetros $\mathrm{D}$ e $\mathrm{C}$ do modelo foram considerados $\mathrm{D}=100$ e $\mathrm{C}=0$, para todos herbicidas. 
Tabela 8. Parâmetros estimados para a variável fitomassa recém colhida aos 15 DAA(1), com os respectivos erros padrōes assintóticos segundo modelo exponencial(2) utilizado para elaboração de curvas de doseresposta de herbicidas inibidores da ACCase em biotipos de Brachiaria plantaginea.

HERBICIDAS

PARÁ-

Biotipo A

Biotipo B

Biotipo S METROS

\begin{tabular}{|c|c|c|c|c|}
\hline & $\bar{a}$ & $16,13 \pm 3,61$ & $34,32 \pm 0,79$ & 0 \\
\hline \multirow[t]{2}{*}{ sethoxydim(3) } & b & $2,27 \pm 3,64$ & $-0,31 \pm 0,03$ & $28,51 \pm 1,44$ \\
\hline & $\mathbf{t}$ & $20,16 \pm 39,61$ & - & $0,07 \pm 0,01$ \\
\hline & $\mathbf{a}$ & 0 & 0 & 0 \\
\hline \multirow[t]{3}{*}{ clethodim } & b & $19,54 \pm 1,71$ & $36,79 \pm 1,53$ & $32,30 \pm 1,78$ \\
\hline & $\mathbf{t}$ & $1,12 \pm 0,35$ & $0,49 \pm 0,07$ & $0,05 \pm 0,18$ \\
\hline & $\mathbf{a}$ & 0 & 0 & 0 \\
\hline \multirow[t]{3}{*}{ butroxydim } & b & $19,29 \pm 1,53$ & $31,19 \pm 2,22$ & $33,86 \pm 1,54$ \\
\hline & $\mathbf{t}$ & $1,47 \pm 0,57$ & $0,72 \pm 0,16$ & $0,03 \pm 0,01$ \\
\hline & $\overline{\mathbf{a}}$ & $6,98 \pm 1,64$ & 0 & $2,61 \pm 3,18$ \\
\hline \multirow[t]{3}{*}{ propaquizafop } & b & $10,72 \pm 1,84$ & $30,77 \pm 1,48$ & $6,20 \pm 4,09$ \\
\hline & $\mathbf{t}$ & $6,24 \pm 3,57$ & $2,39 \pm 0,47$ & $1,87 \pm 5,67$ \\
\hline & $\mathbf{a}$ & $6,26 \pm 6,47$ & $7,05 \pm 2,51$ & 0 \\
\hline \multirow[t]{3}{*}{ diclofop-methyl(3) } & b & $17,79 \pm 6,23$ & $28,77 \pm 3,14$ & $29,58 \pm 2,82$ \\
\hline & $\mathbf{t}$ & $33,78 \pm 34,22$ & $3,16 \pm 1,13$ & $0,16 \pm 0,04$ \\
\hline & $\mathbf{a}$ & $4,45 \pm 1,89$ & 0 & 0 \\
\hline \multirow[t]{3}{*}{ haloxyfop-methyl } & b & $19,39 \pm 2,43$ & $34,4 \pm 1,71$ & $32,57 \pm 1,54$ \\
\hline & $\mathbf{t}$ & $2,35 \pm 0,99$ & $0,68 \pm 0,12$ & $0,05 \pm 0,01$ \\
\hline & $\mathbf{a}$ & $7,53 \pm 1,92$ & 0 & 0 \\
\hline \multirow[t]{3}{*}{ quizalofop-p-ethyl } & $\mathbf{b}$ & $14,98 \pm 2,32$ & $34,25 \pm 2,15$ & $32,89 \pm 1,48$ \\
\hline & $\mathbf{t}$ & $4,07 \pm 2,07$ & $1,25 \pm 0,27$ & $0,07 \pm 0,01$ \\
\hline & $\mathbf{a}$ & $8,97 \pm 2,25$ & $11,85 \pm 3,19$ & 0 \\
\hline \multirow[t]{3}{*}{ fluazifop-p-butil } & b & $14,13 \pm 2,48$ & $22,55 \pm 3,43$ & $32,03 \pm 1,39$ \\
\hline & $\mathbf{t}$ & $8,04 \pm 4,26$ & $11,64 \pm 5,23$ & $0,04 \pm 0,01$ \\
\hline & $\mathbf{a}$ & $7,22 \pm 2,21$ & 0 & 0 \\
\hline \multirow[t]{2}{*}{ fenoxaprop-p-ethyl } & $\mathbf{b}$ & $15,44 \pm 2,39$ & $38,05 \pm 1,36$ & $36,31 \pm 1,35$ \\
\hline & $\mathbf{t}$ & $10,43 \pm 4,89$ & $12,83 \pm 2,19$ & $0,07 \pm 0,01$ \\
\hline
\end{tabular}

(1) DAA = dias apńs aplinaçān dne horhiridac

(2) Equação do modelo exponencial utilizado: $\mathbf{y}=\mathbf{a}+\mathbf{b} \exp (-\mathbf{x} / \mathbf{t})$

(3) Para sethoxydim (biotipo B) foi utilizado o modelo linear: $\mathbf{y}=\mathbf{a}+\mathbf{b x}$ 
Tabela 9. Taxa de resistência para porcentagem de controle visual em relação à testemunha sem herbicida aos $14 \mathrm{DAA}(1)$ e fitomassa recémcolhida, de biotipos de Brachiaria plantaginea tratados com herbicidas inibidores da ACCase.

\begin{tabular}{|c|c|c|c|c|c|}
\hline \multirow[b]{2}{*}{ HERBICIDAS } & \multicolumn{3}{|c|}{$\operatorname{GR}_{50}(2)$ ( L ha-1 de p.c.(3) $)$} & \multicolumn{2}{|c|}{ Taxa de Resistência(4) } \\
\hline & Biotipo A & Biotipo $\mathbf{B}$ & Biotipo $\mathbf{s}$ & Biotipo A & Biotipo B \\
\hline \multicolumn{6}{|c|}{ Controle percentual aos 14 DAA(5) } \\
\hline sethoxydim & 31,34 & 34,90 & 0,04 & 783,5 & 872,5 \\
\hline clethodim & 0,24 & 0,24 & 0,02 & 12,0 & 12,0 \\
\hline butroxydim & 0,44 & 0,58 & 0,03 & 14,7 & 19,3 \\
\hline propaquizafop & 2,88 & 1,13 & 0,04 & 72,0 & 28,3 \\
\hline diclofop-methyl & 10,44 & 4,21 & 0,12 & 87,0 & 35,1 \\
\hline haloxyfop-methyl & 3,01 & 0,56 & 0,04 & 75,3 & 14,0 \\
\hline quizalofop-p-ethyl & 3,79 & 0,81 & 0,05 & 75,8 & 16,2 \\
\hline fluazifop-p-butil & 4,74 & 3,88 & 0,02 & 237,0 & 194,0 \\
\hline fenoxaprop-p-ethyl & 9,91 & 5,71 & 0,04 & 247,8 & 142,8 \\
\hline \multicolumn{6}{|c|}{ Fitomassa recém-colhida (6) } \\
\hline sethoxydim(7) & $>80,0$ & 56,14 & 0,05 & $>1600,0$ & 1122,8 \\
\hline Clethodim & 0,77 & 0,34 & 0,04 & 19,3 & 8,5 \\
\hline Butroxydim & 1,02 & 0,51 & 0,02 & 51,0 & 25,5 \\
\hline Propaquizafop & 8,17 & 1,66 & 0,78 & 10,5 & 2,1 \\
\hline diclofop-methyl & 17,75 & 8,54 & 0,09 & 197,2 & 94,9 \\
\hline haloxyfop-methyl & 5,59 & 0,47 & 0,03 & 186,3 & 15,7 \\
\hline quizalofop-p-ethyl & 8,70 & 0,87 & 0,05 & 174,0 & 17,4 \\
\hline fluazifop-p-butil & 10,59 & 15,00 & 0,02 & 529,5 & 750,0 \\
\hline Fenoxaprop-p-ethyl & 10,44 & 8,89 & 0,05 & 208,8 & 177,8 \\
\hline
\end{tabular}

(1) DAA = dias após aplicação dos herbicidas

(2) $\mathrm{GR}_{50}=$ dose de herbicida necessária para reduzir $50 \%$ do controle ou da produção de fitomassa.

(3) p.c. $=$ produto comercial

(4) Taxa de resistência $=G_{50}(A$ ou $B) / G R_{50}(S)$

(5) Dados de GR50 transferidos da tabela 8

(6) Dados de GR5o estimados através da substituição no modelo exponencial, do valor de y pelo valor de $50 \%$ da fitomassa máxima estimada para cada biotipo.

(7) Não foi possivel calcular o GR5o para o biotipo A, com o herbicida sethoxydim, uma vez que o valor máximo utilizado na escala de doses dos bioensaios não foi suficiente para alcançar este parâmetro. 
Os valores de $\mathrm{GR}_{50}$ para a variável porcentagem de controle, apresentados na Tabela 9, comprovam a diferença de sensibilidade entre os biotipos estudados. Para todos os herbicidas, os biotipos resistentes necessitaram de doses maiores que as recomendadas. para ter o controle reduzido em 50\%. O biotipo suscetivel, por sua vez, apresentou o controle reduzido em 50\%, com doses menores do que as de campo recomendadas. Estes resultados evidenciam a ocorrência de resistência cruzada destes biotipos aos herbicidas inibidores da ACCase, dos grupos químicos dos ariloxifenoxipropionatos e das ciclohexanodionas.

A estimativa dos valores de $\mathrm{GR}_{50}$ para a produçāo de fitomassa recém-colhida, foi realizada com a substituiçāo de $\boldsymbol{\nabla}$, na equaçāo, pelo valor $50 \%$ da produçāo de fitomassa máxima estimada para cada biotipo, aplicada ao modelo exponencial apresentado. Nota-se que o GR $\mathrm{R}_{50}$ dos biotipos resistentes sāo superiores em muitas vezes em relaçāo às estimativas do GR5o para o biotipo suscetivel. Estes dados também comprovam a grande diferença de sensibilidade entre os biotipos estudados, confirmando as observações realizadas com a avaliaçāo percentual de controle visual.

O cálculo do $\mathrm{GR}_{50}$ para os herbicidas apresentou diferenças entre os biotipos. Na Tabela 9, verifica-se que os valores de $\mathrm{GR}_{50}$ para o biotipo A foram, em sua maioria, maiores do que os obtidos para o biotipo $B$, para as duas variáveis (porcentagem de controle e produçāo de fitomassa) estudadas. Dessa forma, elegeu-se o biotipo A para dar prosseguimento aos estudos sobre o mecanismo de resistência, uma vez que o mesmo apresentou maiores fatores de resistência para a maioria dos herbicidas estudados.

Os bioensaios em casa-de-vegetaçāo mostraram que os biotipos resistentes de $B$. plantaginea apresentaram fatores de resistência elevados para porcentagem de controle (biotipo $\mathrm{A}=783,5$ e biotipo $\mathrm{B}=872,5$ ), $\mathrm{e}$ para fitomassa (biotipo $A=1600$ e biotipo $B=1122,8$ ), em relaçāo ao herbicida sethoxydim (Tabela 9). Ensaios iñ vivivo realizados com sethoxydim apresentam valores variáveis de fator de resistência para diferentes espécies: Avena fatua (152) (Heap et al., 1993); Setaria faberi (134) (Stoltenberg \& Wiederholt, 1995) e Digitaria sanguinalis (337) (Wiederholt \& Stoltenberg, 1995). No entanto, Heap 
Digitaria sanguinalis (337) (Wiederholt \& Stoltenberg, 1995). No entanto, Heap \& Morrison (1996) encontraram para um biotipo resistente de Setaria viridis um fator de resistência $>2981$, para sethoxydim.

Os resultados encontrados evidenciam a ocorrência de resistência cruzada dos biotipos estudados aos herbicidas pertencentes aos grupos químicos dos ariloxifenoxipropionatos e ciclohexanodionas. Powles \& Howat (1990) descrevem a resistência cruzada de plantas daninhas quando biotipos que desenvolveram a resistência após uma pressão de seleção por um herbicida, exibem resistência a outro herbicida, que geralmente apresenta o mesmo mecanismo de ação. No caso dos inibidores da ACCase, a resistência de plantas daninhas ocorre devido à mutação da ACCase, que a torna insensivel à ação dos herbicidas. Entretanto, estas mutaçōes podem ocorrer em diferentes locais do gene codificador da ACCase, sendo este fato provavelmente o responsável pelos graus variáveis de insensibilidade aos herbicidas APP e CHD.

A resistência observada encaixa-se no conceito proposto por Holt \& LeBaron (1990) e Warwick (1991) pois manifesta-se dentro de um mesmo mecanismo de ação, e em grupos químicos diferentes. A análise do histórico destas áreas admite a hipótese da seleção destes biotipos resistentes ter sido causada pelo uso intensivo de herbicidas de um mesmo mecanismo de ação, como afirma Sawicki (1987). De acordo com o conceito de Powles \& Howat (1990), trata-se de resistência cruzada, uma vez que os resultados obtidos com os biotipos resistentes são semelhantes tanto para os herbicidas do grupo químico dos ariloxifenoxipropionatos, como para as ciclohexanodionas. 


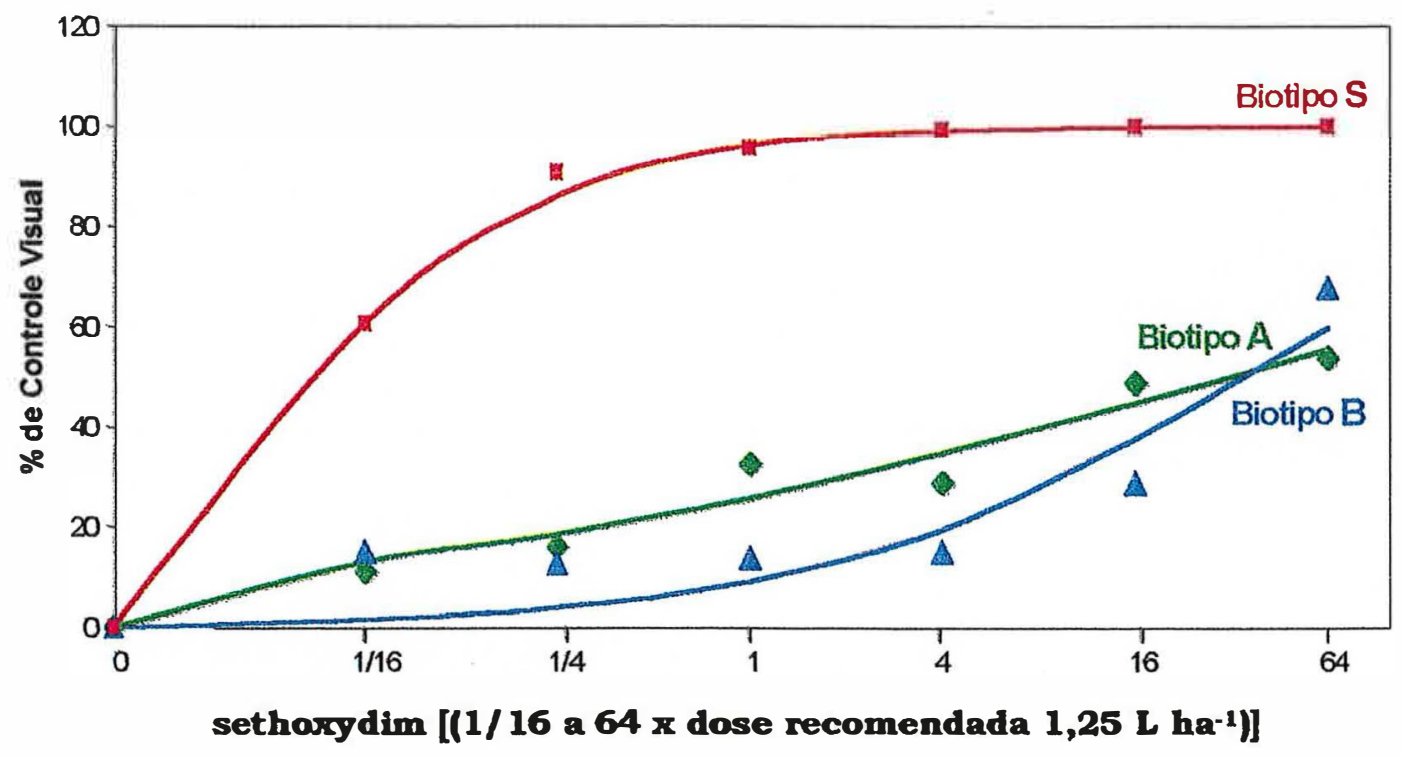

Figura 1. Curvas de dose-resposta da porcentagem de controle visual aos 14 DAA, em biotipos de Brachiaria plantaginea tratados com sethoxydim, segundo modelo log-logistico.

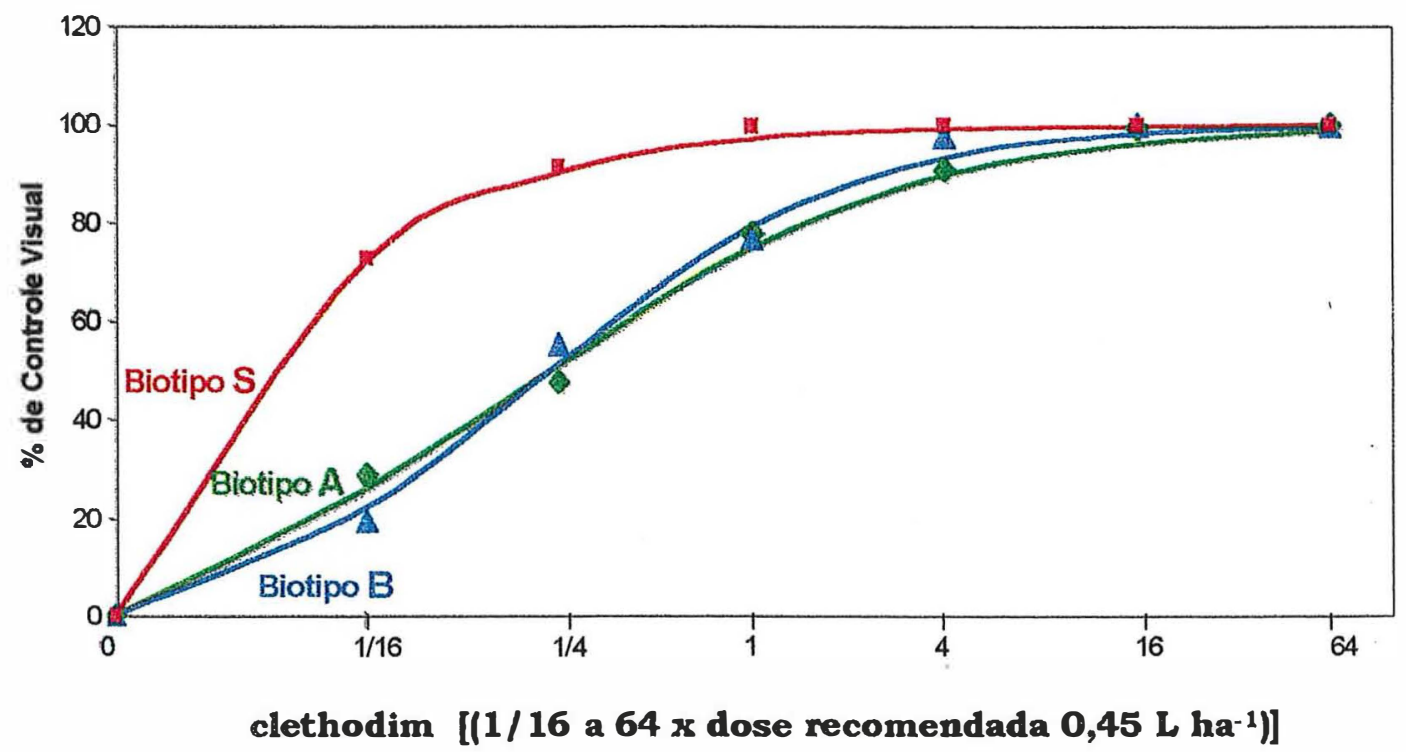

Figura 2. Curvas de dose-resposta da porcentagem de controle visual aos 14 DAA, em biotipos de Brachiaria plantaginea tratados com clethodim, segundo modelo log-logistico. 


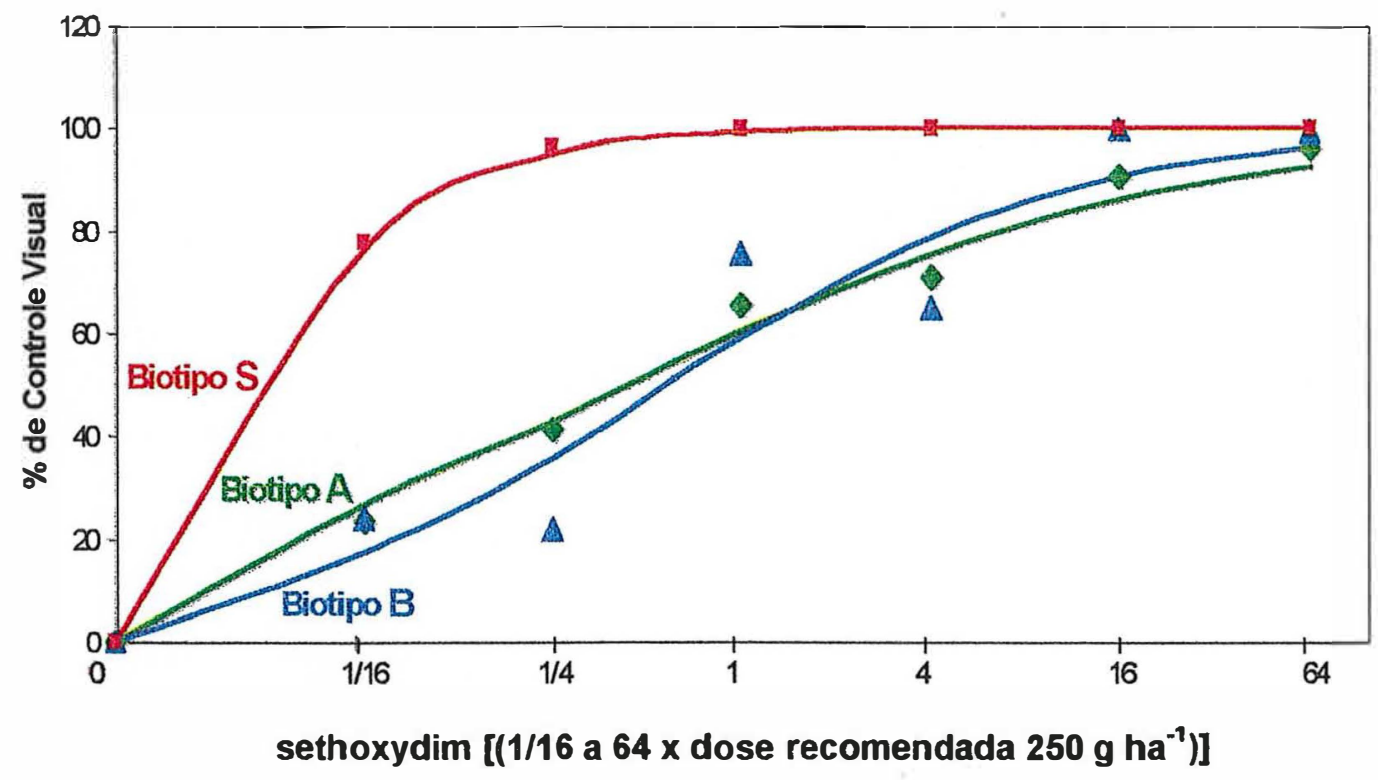

Figura 3. Curvas de dose-resposta da porcentagem de controle visual aos 14 DAA, em biotipos de Brachiaria plantaginea tratados com butroxydim, segundo modelo log-logistico.

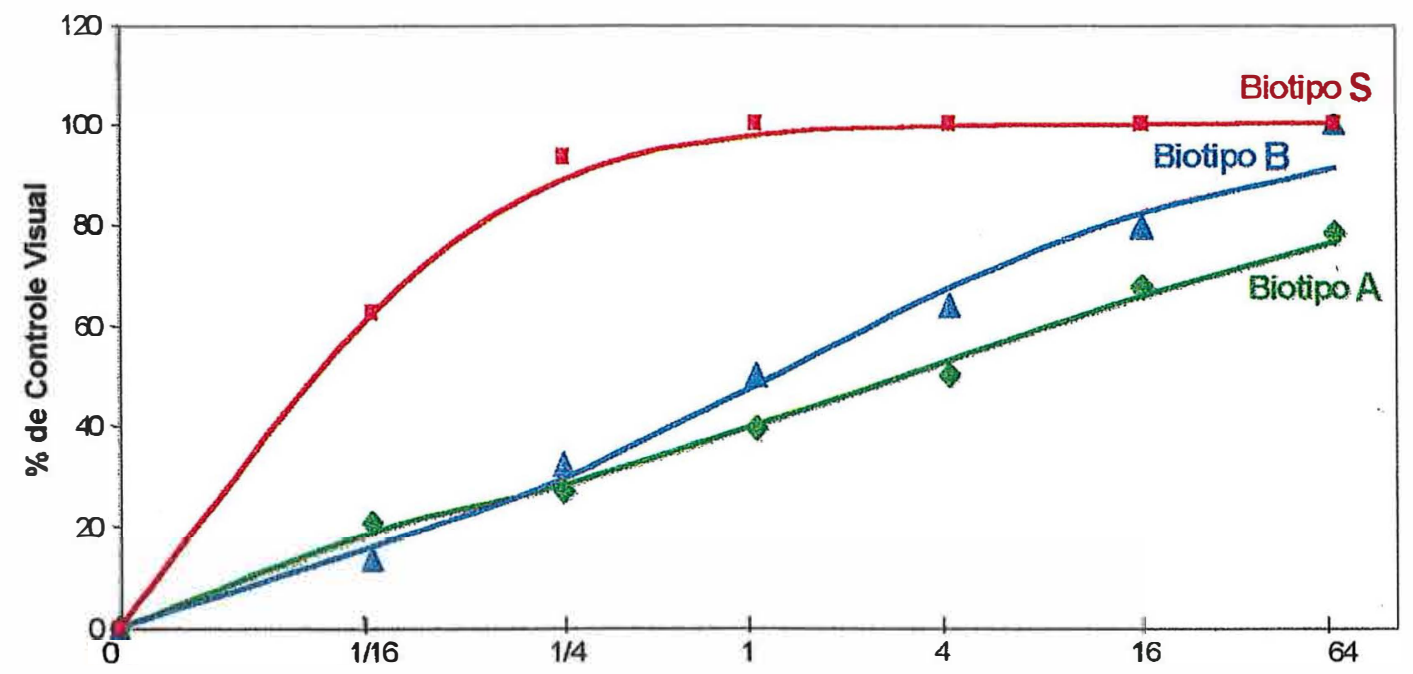

propaquizafop [(1/16 a $64 \times$ dose recomendada 1,25 $L$ ha-1)]

Figura 4. Curvas de dose-resposta da porcentagem de controle visual aos 14 DAA, em biotipos de Brachiaria plantaginea tratados com propaquizafop, segundo modelo log-logistico. 


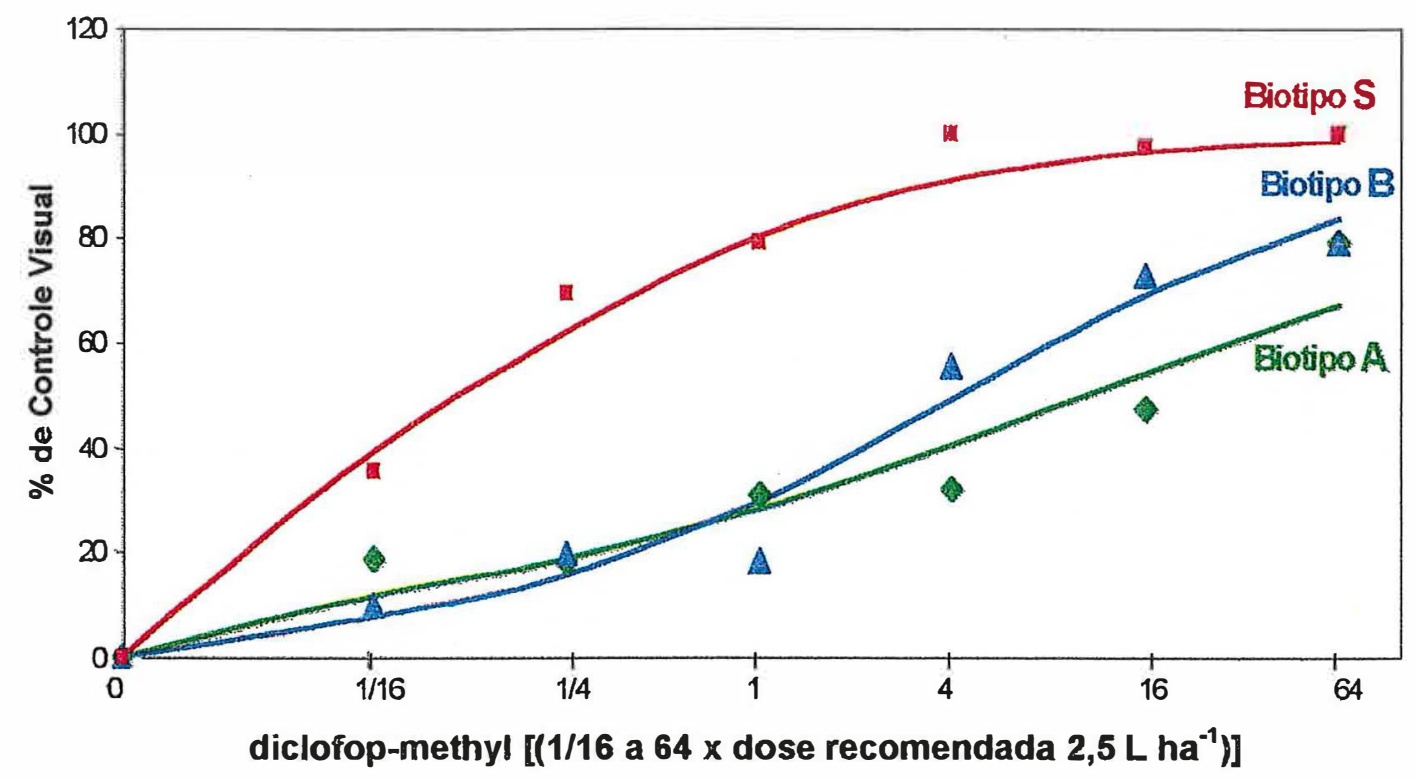

Figura 5. Curvas de dose-resposta da porcentagem de controle visual aos 14 DAA, em biotipos de Brachiaria plantaginea tratados com diclofopmethyl, segundo modelo log-logistico.

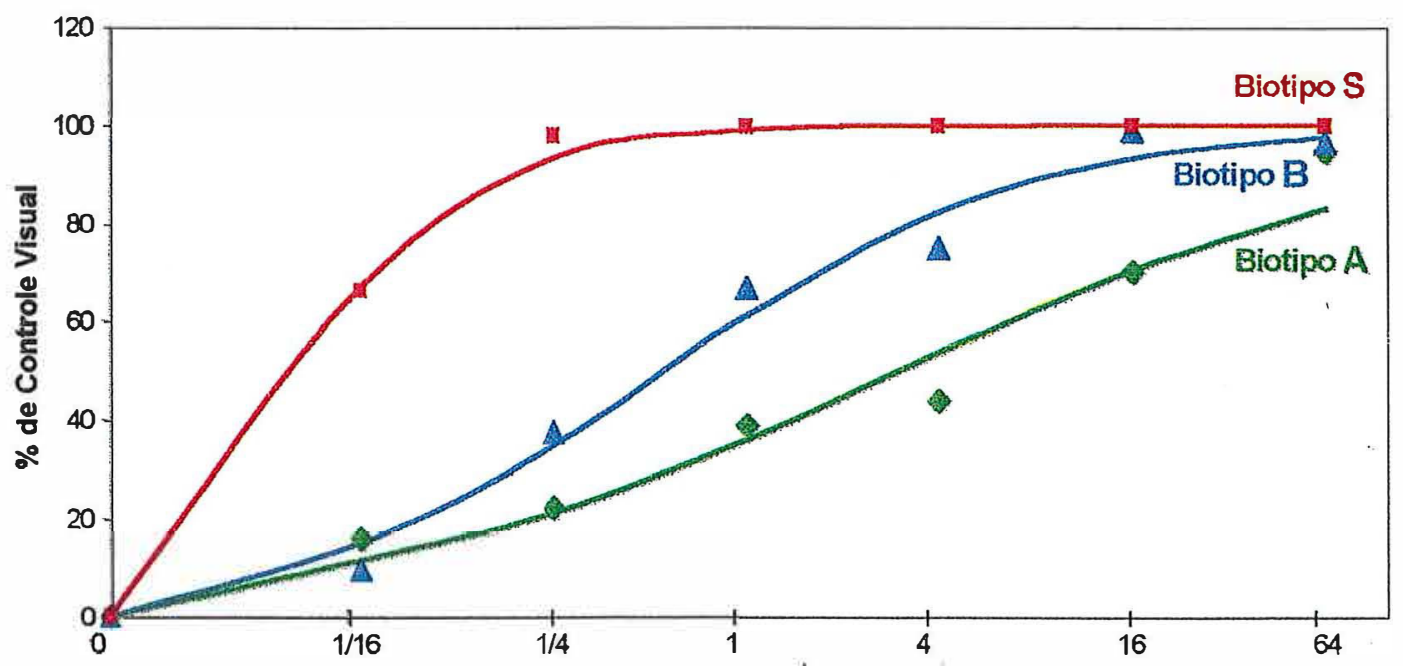

haloxyfop-methyl [(1/16 a $64 \times$ dose recomendada $\left.\left.0,5 L \mathrm{ha}^{-1}\right)\right]$

Figura 6. Curvas de dose-resposta da porcentagem de controle visual aos 14 DAA, em biotipos de Brachiaria plantaginea tratados com haloxyfopmethyl, segundo modelo log-logistico. 


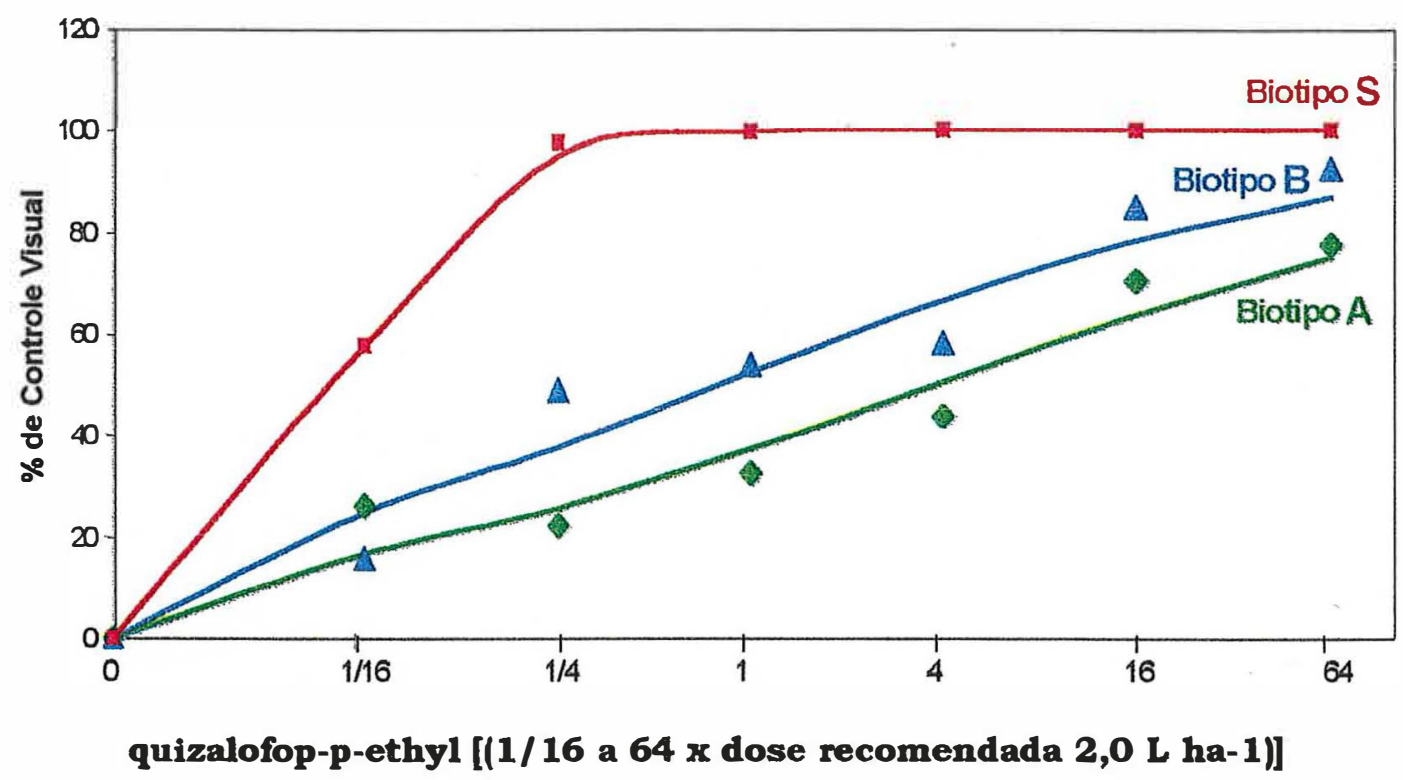

Figura 7. Curvas de dose-resposta da porcentagem de controle visual aos 14 DAA, em biotipos de Brachiaria plantaginea tratados com quizalofopp-ethyl, segundo modelo log-logistico.

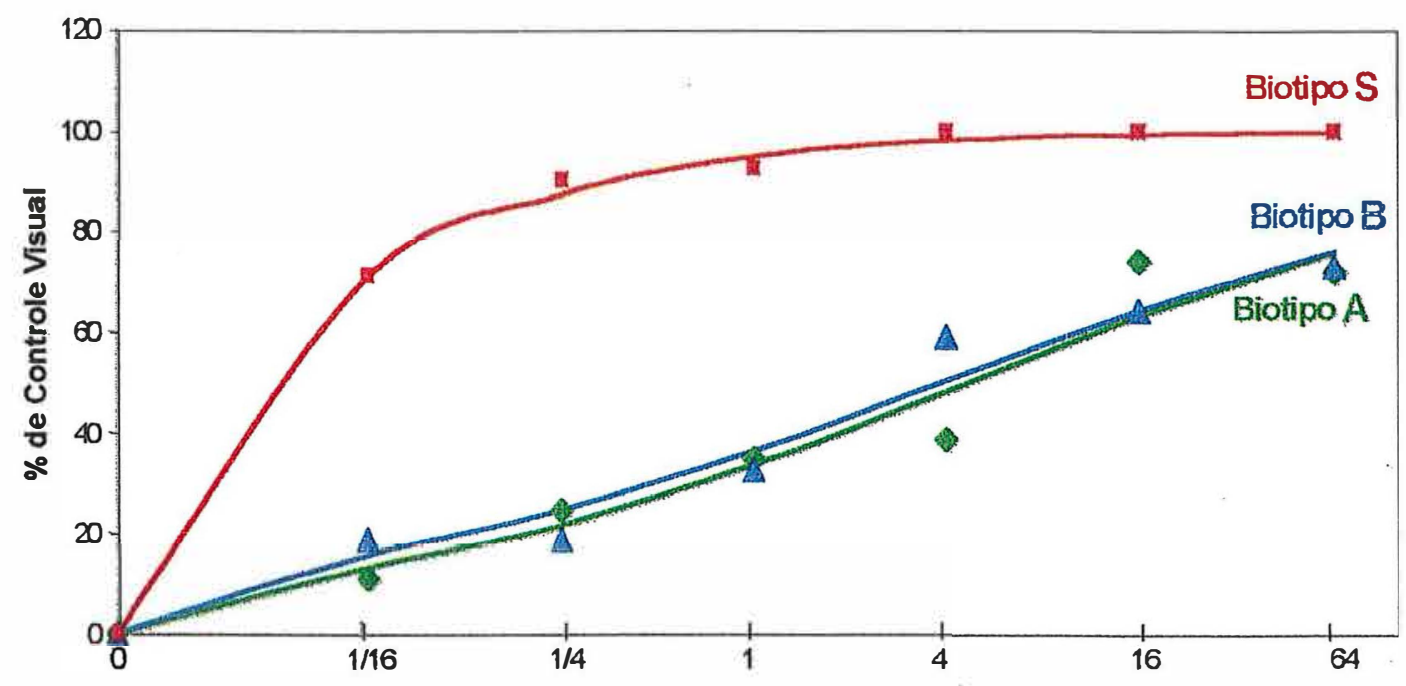

fluazifop-p-butil [(1/ 16 a $64 \approx$ dose recomendada $\left.\left.2,0 \mathrm{~L} \mathrm{ha} \mathrm{ha}^{-1}\right)\right]$

Figura 8. Curvas de dose-resposta da porcentagem de controle visual aos 14 DAA, em biotipos de Brachiaria plantaginea tratados com fluazifopmethyl, segundo modelo log-logistico. 


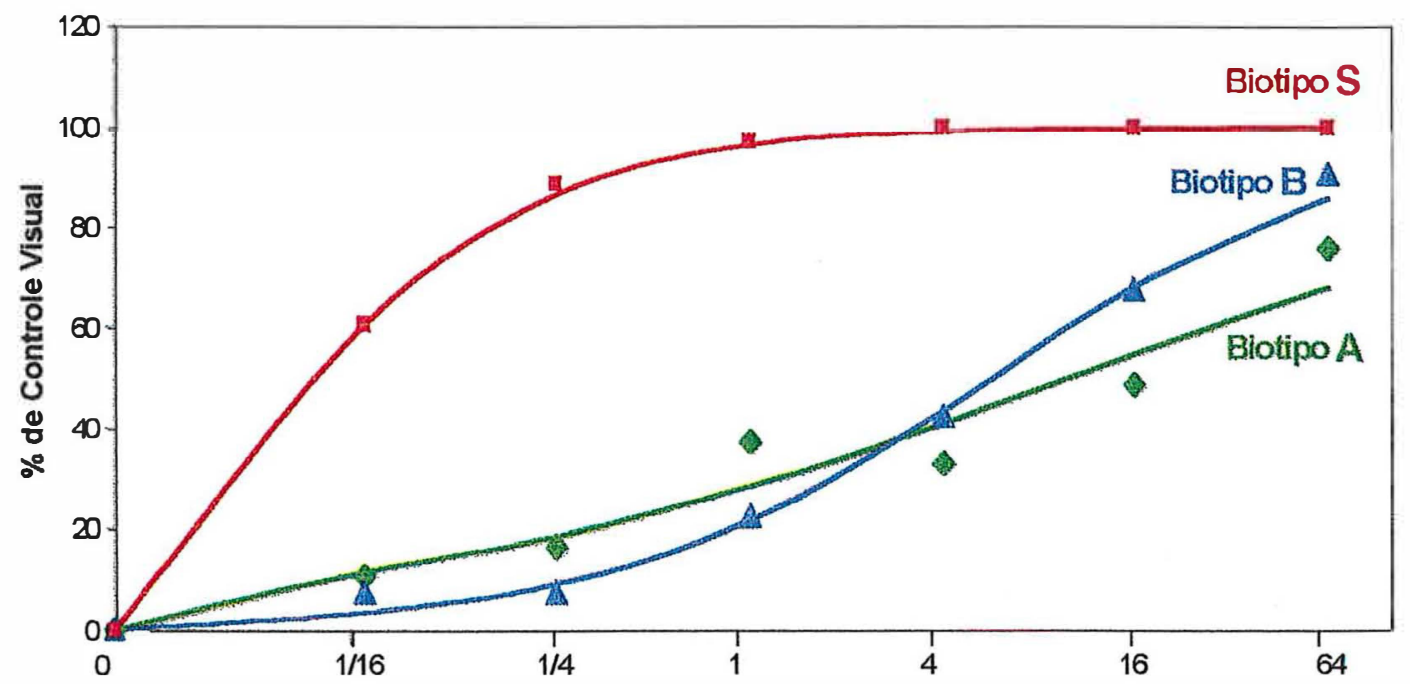

Fenoxaprop-p-ethyl [(1/16 a $64 x$ dose recomendada 0,82 L ha-1)]

Figura 9. Curvas de dose-resposta da porcentagem de controle visual aos 14 DAA, em biotipos de Brachiaria plantaginea tratados com fenoxaprop-p-ethyl, segundo modelo log-logistico. 


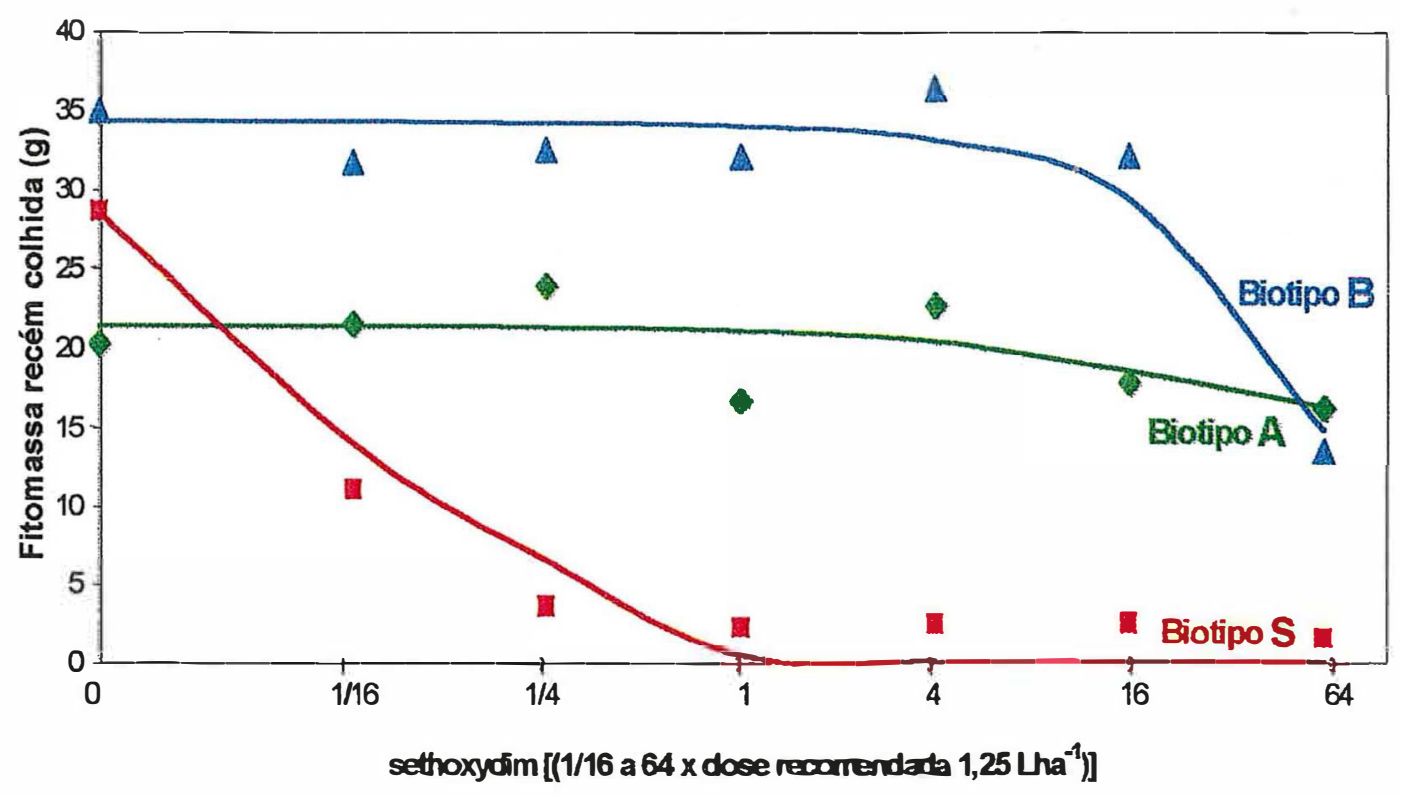

Figura 10. Curvas de dose-resposta da fitomassa recém colhida aos 14 DAA dos biotipos $\mathbf{A}$ e $\mathbf{S}$ de Brachiaria plantaginea tratados com sethoxydim, segundo modelo exponencial. A curva para o biotipo B foi obtida segundo modelo linear.

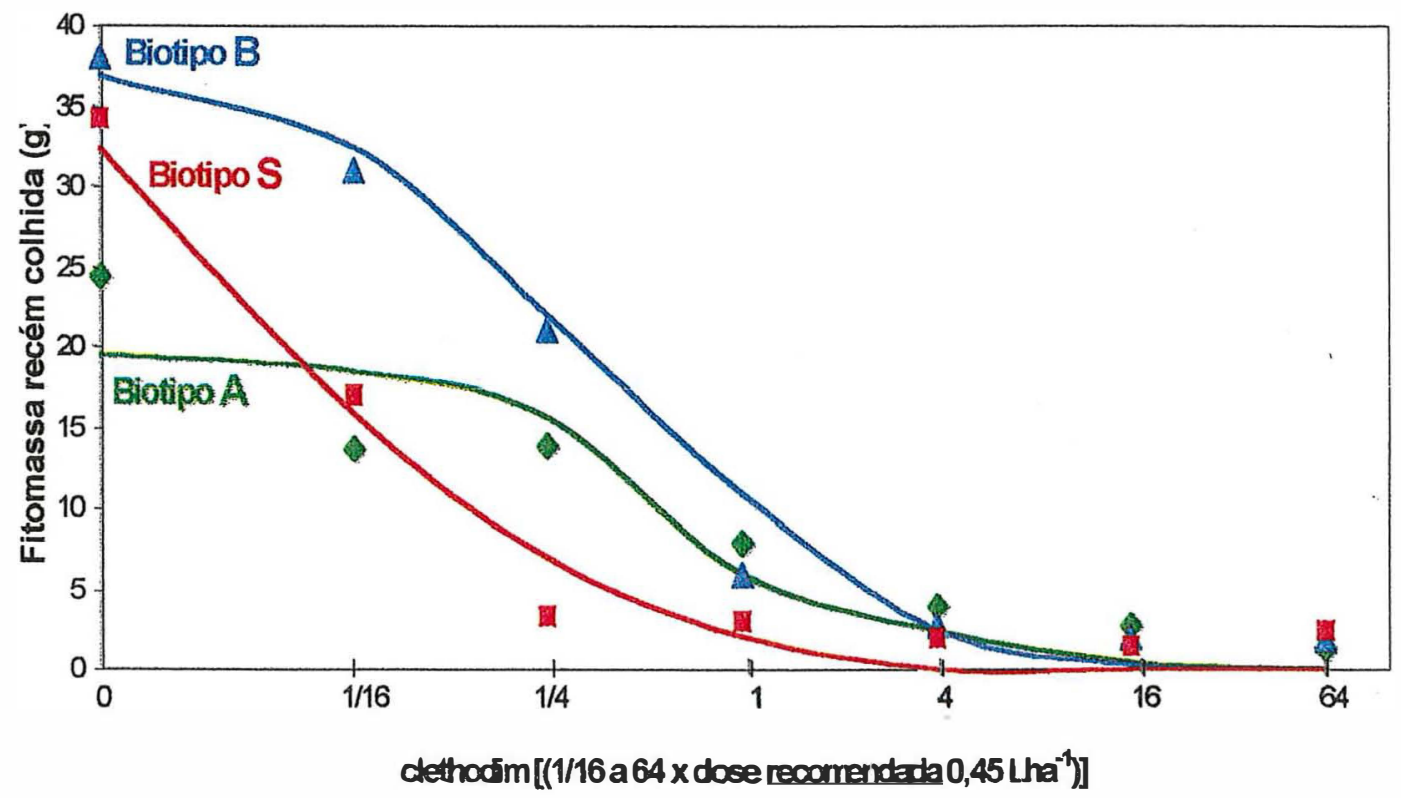

Figura 11. Curvas de dose-resposta da fitomassa recém colhida aos 14 DAA dos biotipos de Brachiaria plantaginea tratados com clethodim, segundo modelo exponencial. 


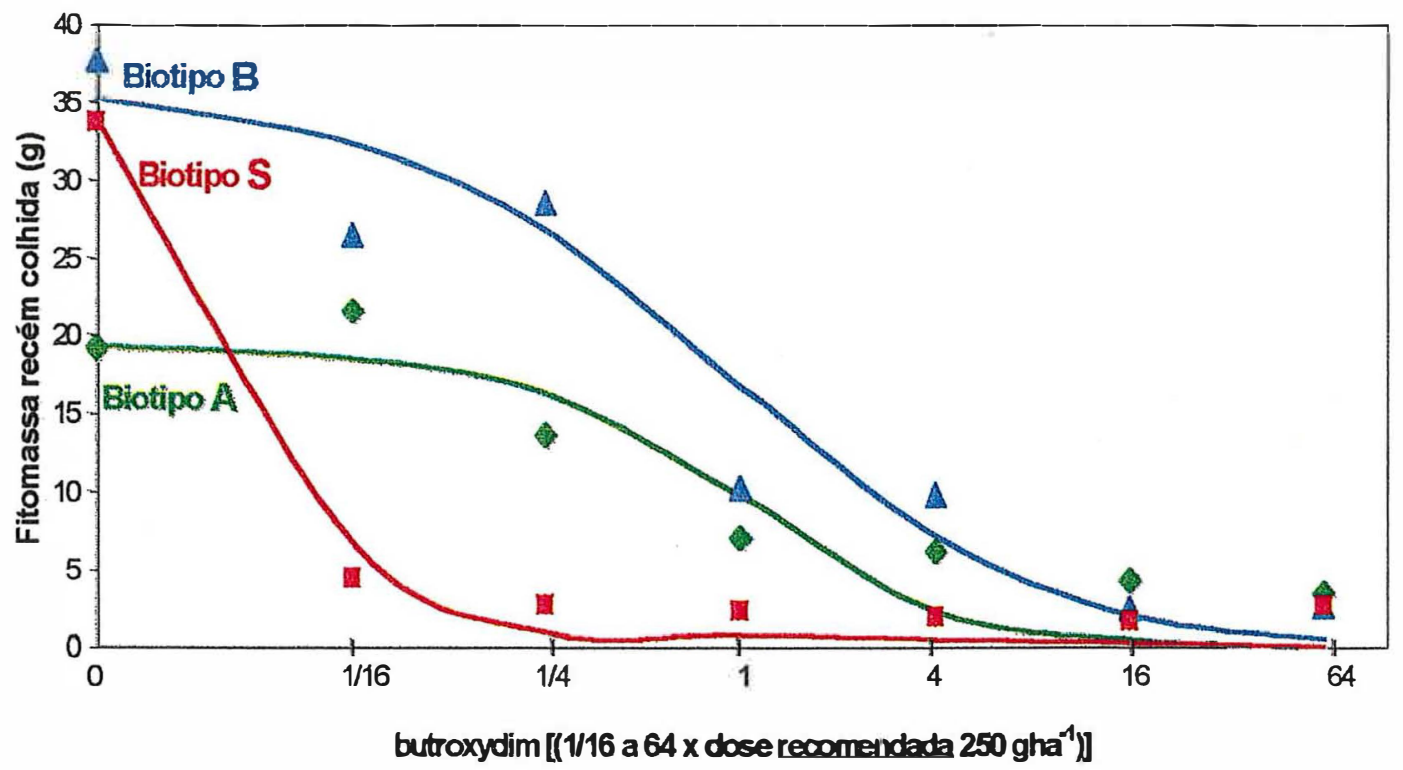

Figura 12. Curvas de dose-resposta da fitomassa recém colhida aos 14 DAA dos biotipos de Brachiaria plantaginea tratados com butroxydim, segundo modelo exponencial.

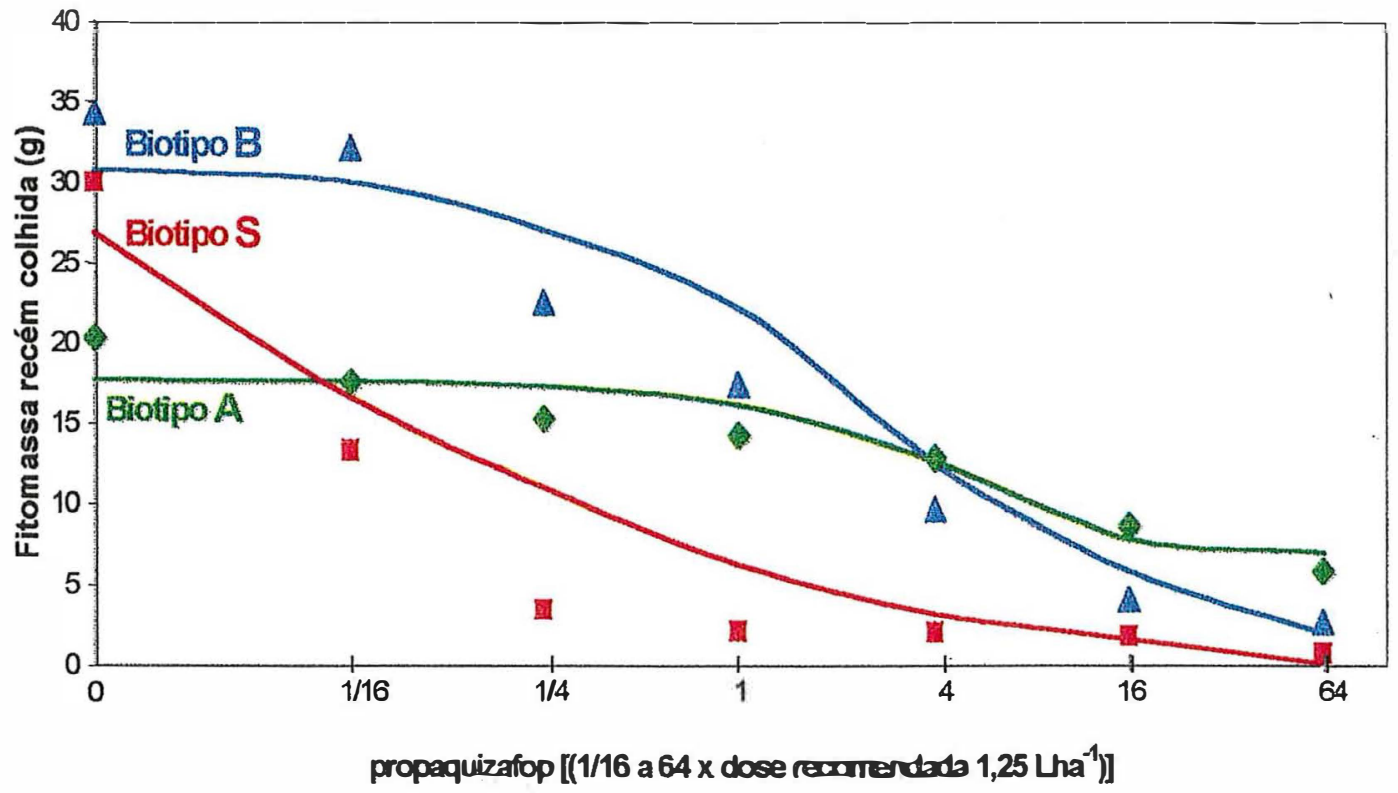

Figura 13. Curvas de dose-resposta da fitomassa recém colhida aos 14 DAA dos biotipos de Brachiaria plantaginea tratados com propaquizafop, segundo modelo exponencial. 


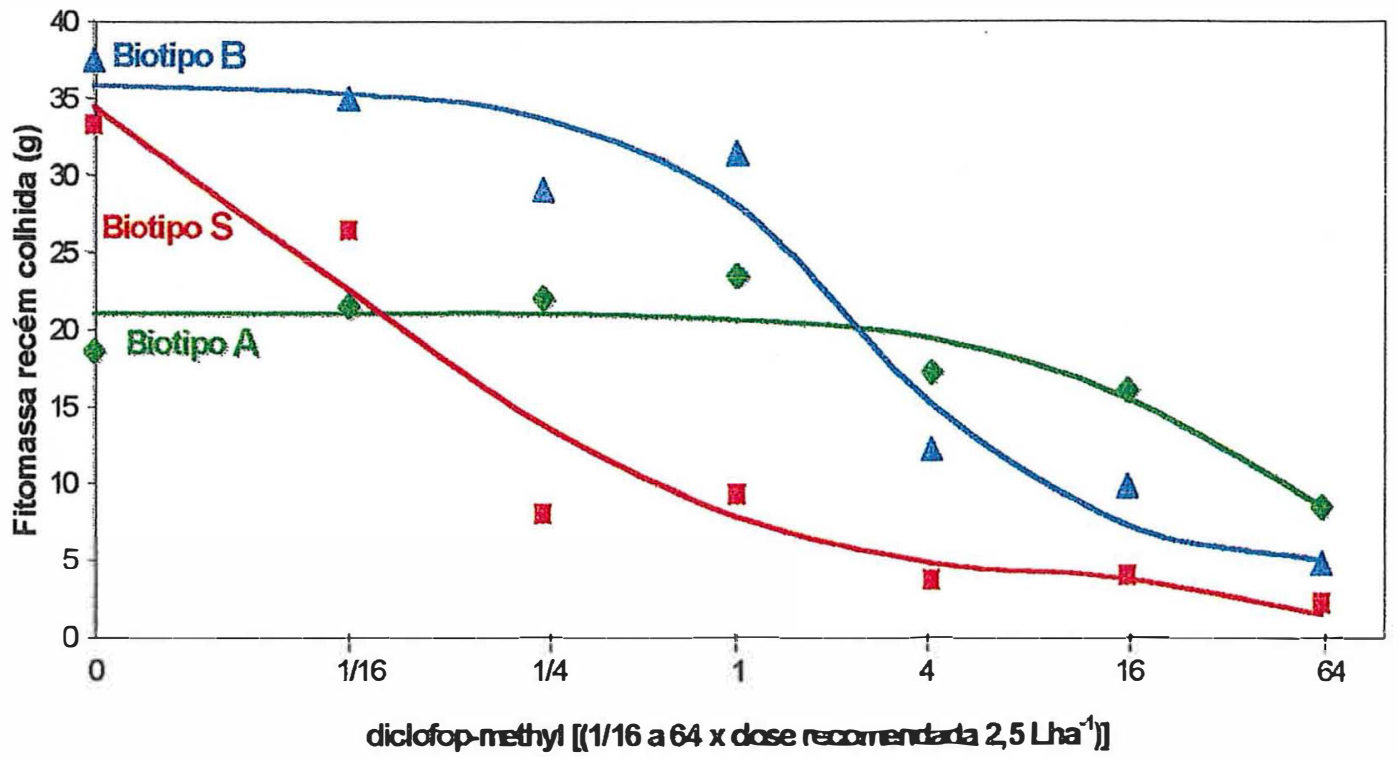

Figura 14. Curvas de dose-resposta da fitomassa recêm colhida aos 14 DAA dos biotipos de Brachiaria plantaginea tratados com diclofopmethyl, segundo modelo exponencial.

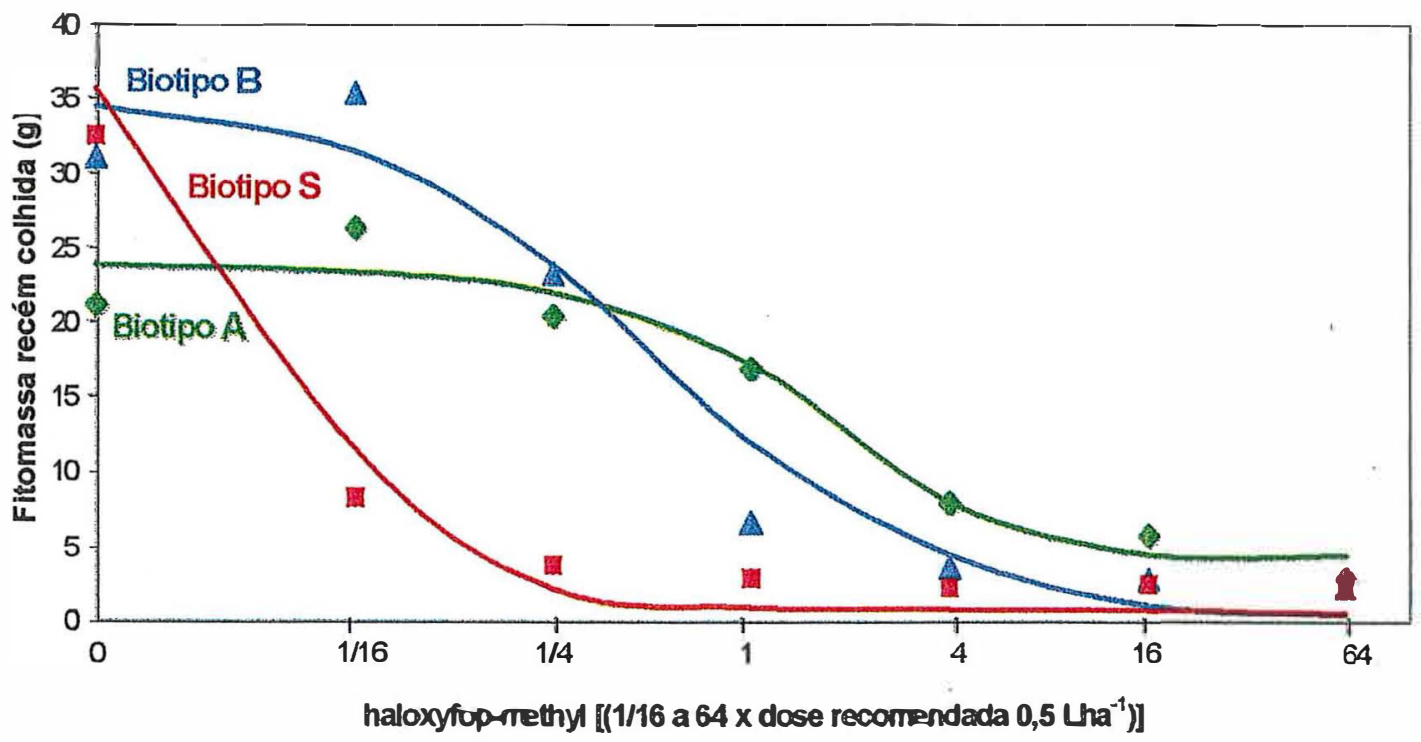

Figura 15. Curvas de dose-resposta da fitomassa recém colhida aos 14 DAA dos biotipos de Brachiaria plantaginea tratados com haloxyfopmethyl, segundo modelo exponencial. 


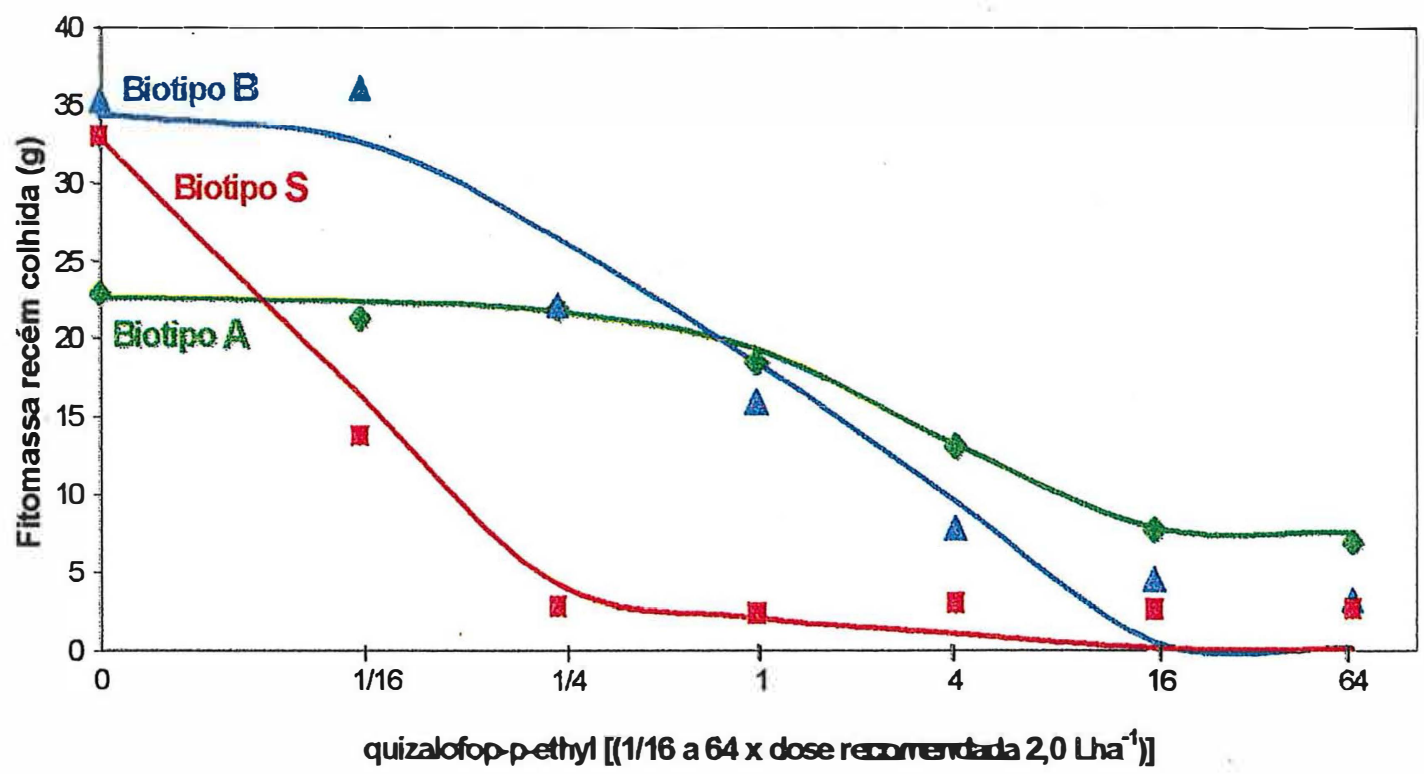

Figura 16. Curvas de dose-resposta da fitomassa recém colhida aos 14 DAA dos biotipos de Brachiaria plantaginea tratados com quizalofop-pethyl, segundo modelo exponencial.

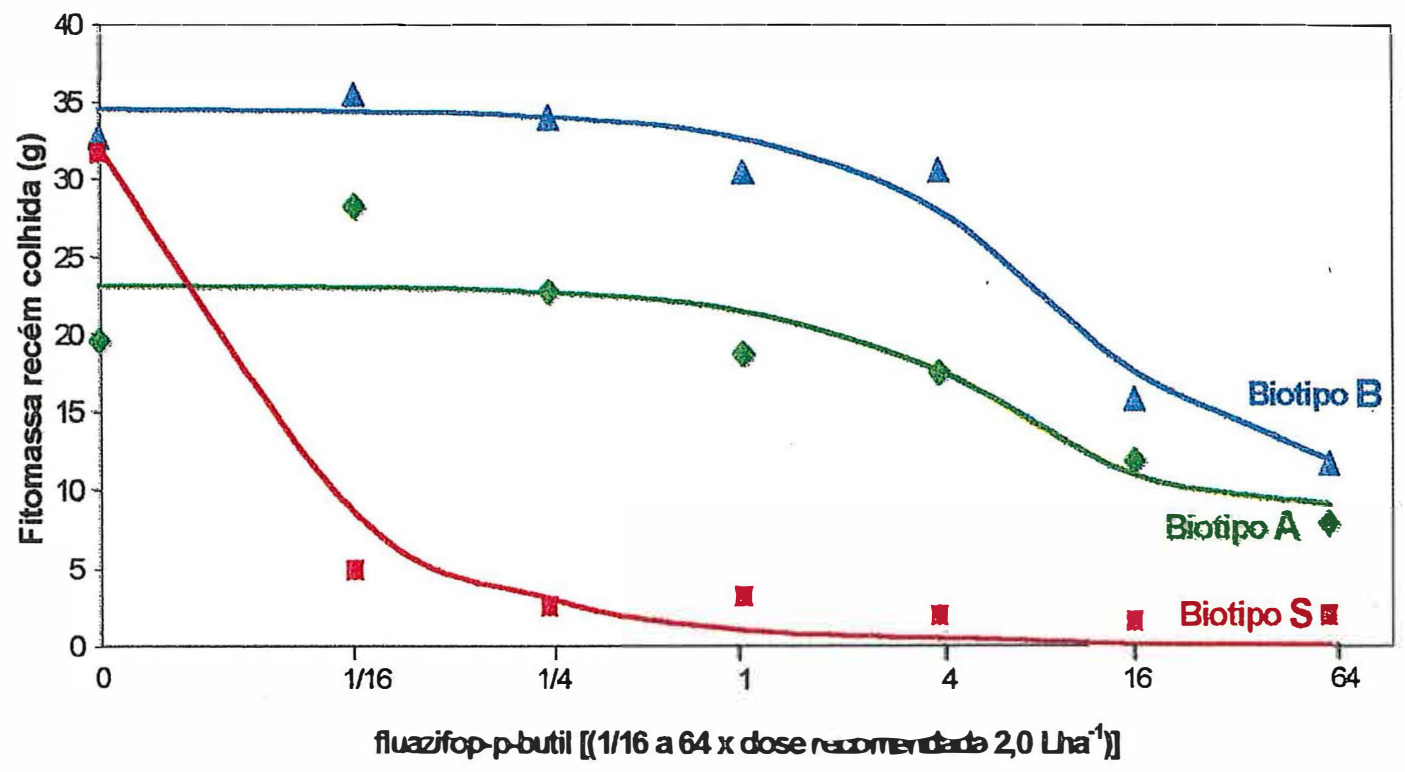

Figura 17. Curvas de dose-resposta da fitomassa recém colhida aos 14 DAA dos biotipos de Brachiaria plantaginea tratados com fluzifop-pbutil, segundo modelo exponencial. 


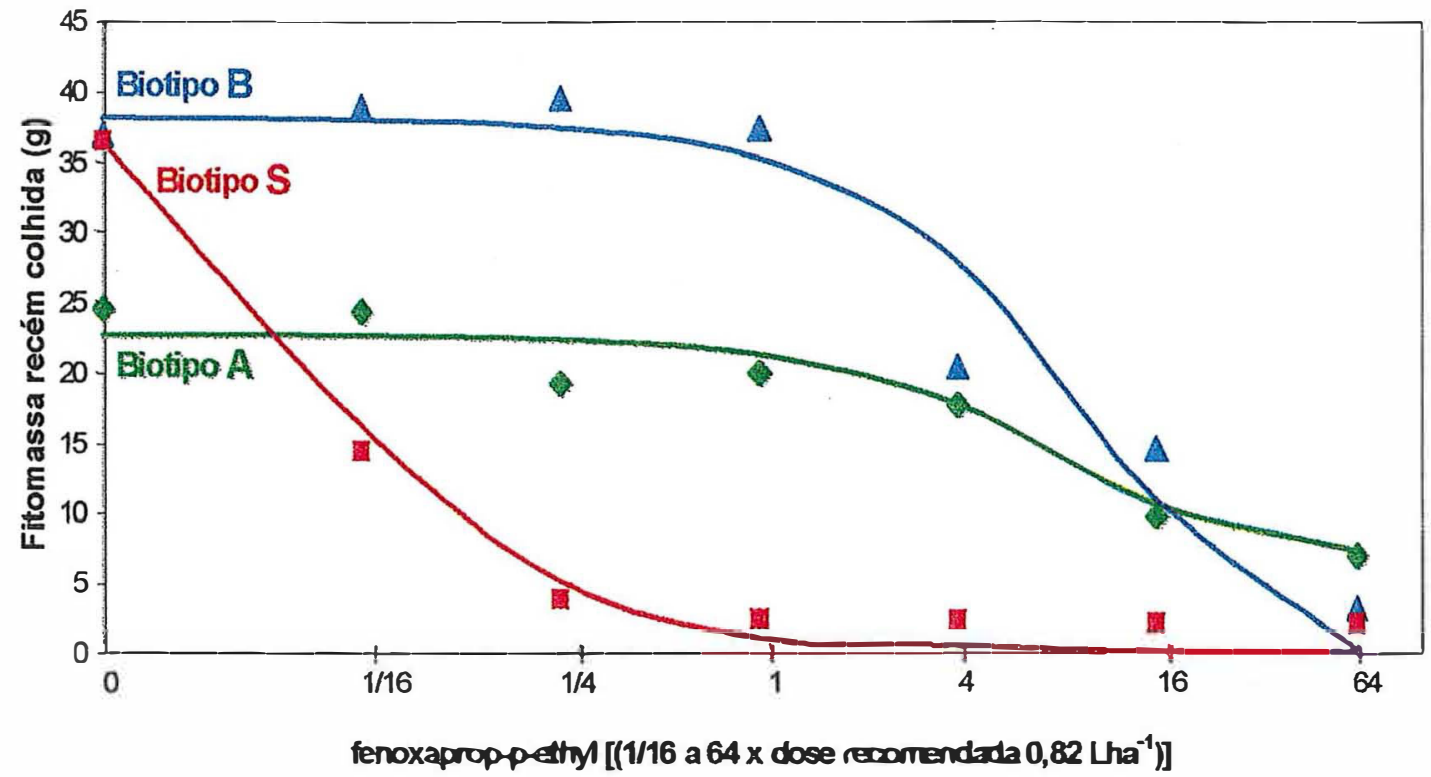

Figura 18. Curvas de dose-resposta da fitomassa recém colhida aos 14 DAA dos biotipos de Brachiaria plantaginea tratados com fenoxaprop-pethyl, segundo modelo exponencial. 


\section{CONCLUSŌES}

Nas condiçōes em que os ensaios foram realizados, os resultados obtidos permitem extrair as seguintes conclusōes:

- As populaçōes de $B$. plantaginea estudadas apresentaram niveis variados de sensibilidade aos herbicidas APP e CHD testados, sendo que a populaçāo suscetivel foi eficazmente controlada por estes produtos;

- Os biotipos resistentes estudados apresentaram resistência cruzada a diferentes herbicidas pertencentes aos grupos quimicos APP e CHD;

- De modo geral, o biotipo A apresentou maior resistência em relaçāo ao outro biotipo testado. 


\section{REFERÊNCIAS BIBLIOGRÁFICAS}

BARTLETT, M.S. Properties of sufficiency and statistical tests. Proc. Royal Soc., v.160, p. 268-282, 1937.

CHRISTOFFOLETI, P.J.; CORTEZ, M.G. e VICTORIA FILHO, R. Resistance of alexanderweed (Brachiaria plantaginea) to ACCase inhibitor herbicides in soybean from Paraná State - Brazil. In: MEETING OF THE WEED SCIENCE SOCIETY OF AMERICA, CHICAGO, 1998. Abstracts. Chicago: WSSA, 1998. p. 65.

CORTEZ, M.G. CHRISTOFFOLETI, P.J.; VICTORIA FILHO, R.; DE PRADO, R. Differential tolerance to graminicides in Brachiaria plantaginea biotypes found in Brazil. In: $11^{\text {th }}$ SYMPOSIUM OF EUROPEAN WEED RESEARCH SOCIETY, 1999. Procedings. Basel: Switzerland, 1999. p.164

DE PRADO, R.; LOPEZ, N. Resistencia a herbicidas: Detección en campo y laboratorio. In: I CURSO SOBRE EL USO DE HERBICIDAS EN LA AGRICULTURA MODERNA. Cordoba/Espanha, 1999. Resumos. ETSIAM/UCO, 1999. p. 52.

DEVINE, M.D. Mechanisms of resistance to acetyl coenzyme A carboxylase inhibitors: a review. Pesticide Science, v.51, p.259-264, 1997.

DEVINE, M.D.; SHIMABUKURO, R.H. Acetyl coenzyme A carboxylase inhibiting herbicides. In: POWLES, S.B. ; HOLTUM, J. A.M. eds Herbicide Resistance in Plants: Biology and Biochemistry, p.141-169. CRC Press, London. 1994. 
FREITAS, R.R. de; CARVAlHO, A. de; ALVAREnGA, A. A.de Quebra de dormência e germinaçāo de sementes de capim-marmelada (Brachiaria plantaginea). Revista Brasileira de Fisiologia Vegetal. v.2, p.31-35. 1990.

GAZZIERO, D.L.P; CHRISTOFFOLETI, P.J.; MACIEL, C.D.M.; SCARAMUZA JÚNIOR., J.R. Resistência de biótipos de Brachiaria plantaginea aos herbicidas inibidores da ACCase aplicados em soja. In: CONGRESSO BRASILEIRO DA CIÊNCIA DAS PLANTAS DANINHAS. 21, Caxambu/MG,1997. Resumos. Caxambu:SBCPD, 1997. p.88.

HEAP, I.M. The ocurrence of herbicide-resistant weeds worlwide. Pesticide Science, v.51, p.235-243, 1997.

HEAP, I.M.; MORRISON, I.N. Resistance to aryloxyphenoxypropionate and cyclohexanodione herbicides (Group 1) herbicides in Green foxtail (Setaria viridis L. Beav.). WSSA Abstracts. Denver, Colorado. 55: p.164. 1982.

HEAP, I.M.; MURRAY, B.G.; LOEPPKY, H.A.; MORRISON, I.N. Resistance to aryloxyphenoxypropionate and cyclohexanodione herbicides in wild oat (Avena fatua). Weed Science, v.41, p.232-238, 1993.

HOLT, J.S.; LeBARON, H.M. Significance and distribution of herbicide resistance. Weed Technology, n.4, p.141-49, 1990.

KISSMANN, K.G. Plantas infestantes e nocivas. 1ed. São Paulo, SP: BASF Brasileira S.A., 1991. 603p.

LILLIEFORS, H.W. On the Kolmoganov - Smimov test for normality with mean and variance unknown. Journal American Statistical, v.62, p.399-402, 1967. 
MALLORY-SMITH, C.A.; THILL, D.C.; MORISHITA, D. Herbicide-resistant weeds and their management. Corvallis: Oregon State University. PNW Extension Publication, 1993. 437p.

POWLES, S.B.; PRESTON, C. Herbicide cross resistance and multiple resistance in plants. Departament of crop protection. Waite Agricultural Research Institute. University of Adelaide. South Australia, 1995. 34 p.

RYAN, G.F. Resistance of common groundsel to simazine and atrazine. Weed Science, v.18, p.614-616, 1970.

SAWICKI, R.M. Definition, detection and documentation of insecticide resistance. In: FORD, M.G.; HOLLMAN, D.W.; KHAMBAY, B,. SAWICKI, R.M. Combating Resistance to Xenobiotics: Biological and Chemical Approaches. Ellis Horwood, Ed. Chichester, 1987. p.105-117.

SEEFELDT, S.S.; FUERST, E.P.; IRZYK, G.P.; GEALY, D.R.; SHUKLA, A. HOFFMAN, D.; BREWSTER, B.D. Diclofop-resistant Avena fatua from the Willamette Valley of Oregon, Weed Science, v.44, p.776-781, 1996.

SEEFELDT, S.S.; GEARLY, D.R.; BREWSTER, B.D.; FUERST, E.P. Crossresistance of several diclofop-resistant wild oat (Avena fatua) biotypes from the Willamette Valey of Oregon. Weed Science, v.42, p.430-437, 1994.

SEEFELDT, S.S.; JENSEN, J.E.; FUERST, E.P. Log-logistc analysis of herbicide dose-response relationships. Weed Technology. v. 9, n.2, p. 218-227, 1995.

SENDULSKY, T. Brachiaria: taxonomy of cultivated and native species in Brazil. Hoehnea, v.7, p.99-139, 1978. 
SILVERTOWN, J.W. Introduction to plant population ecology. New York: Longman. 2.ed. 1987. 220p.

STOLTENBERG, D.E.; WIEDERHOLT, R.J. Giant foxtail (Setaria faberi) resistance to aryloxyphenoxypropionate and cyclohexanedione herbicides. Weed Science, v.43, p.527-535, 1995.

STOLTENBERG, D.E.; WYSE, D.L. Regrowth of Quackgrass (Agropyron repens) Following Postemergence Applications of Haloxyfop and Sethoxydim. Weed Science. v. 34, p.664-668, 1986.

VIDAL, R.A.; FLECK, N.G. Three weed species with confirmed resistance to herbicides in Brazil. In: MEETING OF THE WEED SCIENCE OF AMERICA, 1997. Abstracts. p. 100.

WIEDERHOLT, R.J.; STOLTENBERG, D.E. Cross-resistance of a large crabgrass (Digitaria sanguinalis) accession to aryloxyphenypropionate and cyclohexanedione herbicides. Weed Technology, v.9, n.3, p.518-524, 1995. 


\section{CAPÍtulo IV}

\section{MECANISMOS DE RESISTÊNCIA A HERBICIDAS INIBIDORES DA ACETIL COENZIMA A CARBOXILASE (ACCase) EM BIOTIPOS DE Brachiaria plantaginea (Link) Hitchc.}

RESUMO: Experimentos de laboratório foram conduzidos para determinar o mecanismo de resistência em biotipo resistente de $B$. plantaginea. Os resultado dos ensaios de absorçāo e translocaçāo demostraram que apesar dos biotipos resistente (R) e suscetivel (S) apresentarem diferenças quanto a absorçāo e translocaçāo, verificadas em ambos herbicidas testados (sethoxydim e tepraloxydim), estas nāo sāo suficientes para justificar a resistência aos herbicidas inibidores da ACCase. Comparados ao biotipo S, a ACCase isolada de $\mathrm{R}$ apresentou $\mathrm{I}_{50}$ (concentraçāo de herbicida necessária para inibir 50\% da atividade da ACCase) 216,7 vezes maior para o sethoxydim, e 2,3 vezes maior para o tepraloxydim. Desta forma é possivel concluir-se que a resistência aos CHD sethoxydim e tepraloxydim, é devido a presença de uma forma tolerante, ou alterada de ACCase nas plantas resistentes.

Palavras-chave: atividade ACCase, mecanismos de resistência, herbicidas APP e CHD, plantas daninhas resistentes.

SUMMARY: Laboratory experiments were conducted to determine the mechanism of resistance in biotypes of $B$. plantaginea. The results absorption and translocation assays showed that even tough resistant (R) and susceptible 
(S) biotypes presented differences in absorption and translocation, for both herbicides (sethoxydim and tepraloxydim), these are not enough to justify the resistance to ACCase inhibitor herbicides. Compared to S biotype, the ACCase isolated from $\mathrm{R}$ biotype presented $\mathrm{I}_{50}$ (concentration of herbicide necessary to inhibit 50\% of the ACCase activity) 216.7 times higher for sethoxydim, and 2.3 times higher for tepraloxydim. So it is possible to conclude that the resistance to CHD sethoxydim and tepraloxydim is due to the presence of a tolerant form, or altered of ACCase in resistant plants.

Key words: ACCase activity, resistant mechanisms; APP and CHD herbicides, resistant weeds.

\section{INTRODUÇĀO}

Os herbicidas devem atingir os pontos meristemáticos sensiveis em suas formas tóxicas e em concentraçōes suficientes para interromper o crescimento e desenvolvimento normal de células sensiveis. Além disso, as injúrias causadas pelos herbicidas devem se manter num nivel mínimo, durante o periodo crítico, após o qual os prejuízos resultam irreversiveis e a morte das células é inevitável.

Dentre os mecanismos gerais conhecidos até o momento, existem pelo menos dois que podem explicar o desenvolvimento da resistência a herbicidas (Sherman et al., 1996) e influenciar o modo de ação destes compostos: a) translocação reduzida do herbicida pelo biotipo resistente e; b) perda de sensibilidade ou afinidade da enzima pelo local de ação.

A translocação dos herbicidas nas plantas pode ser determinada pelo tipo de aplicação do produto, em pré ou pós-emergência. O movimento dos herbicidas após a sua absorçāo via foliar pode seguir rotas diferentes, segundo seu transporte se realize no xilema ou no floema. Enquanto o transporte de herbicidas via xilema segue livremente o fluxo de água na planta até as margens foliares e os espaços intercelulares (Bromilow \& Chamberlain, 
1991), o transporte via floema vai depender de dois fatores diferenciados: o gradiente de concentraçāo do herbicida entre as células do floema e do mesófilo, e a capacidade das células floemáticas reterem o herbicida durante o transporte (Tryee et al., 1979).

A absorçāo e a translocaçāo de diclofop-methyl e de outros herbicidas APP parecem nāo ser significativas na açāo seletiva destes herbicidas entre plantas resistentes e suscetiveis (Duke \& Kenyon, 1988; Shimabukuro, 1990).

A maioria dos herbicidas APP e CHD sāo particularmente ativos sobre gramineas anuais, com pouca atividade sobre plantas perenes. As diferenças entre os herbicidas, quanto a mobilidade no floema, responsáveis pela quantidade de herbicida translocado das folhas aos rizomas e pela atividade biológica dos compostos individuais, podem ser consideradas como causas da variaçāo nos niveis de atividade destes produtos em plantas daninhas perenes. A translocaçāo destes herbicidas ocorre via apossimplasto e varia com o herbicida, a espécie daninha e o estádio de desenvolvimento das mesmas (Ahrens, 1994). Os compostos ésteres dos APP sāo rapidamente absorvidos pelas folhas e raizes de plantas resistentes e suscetiveis, porém o transporte a longa distāncia pode ser limitado, principalmente no caso do diclofop (Shimabukuro, 1990 e Devine et al., 1992). Compostos auxínicos parecem aumentar levemente a absorção e conjugação do éster de diclofopmethyl, porém a translocaçāo e detoxificaçāo sāo muito pouco afetadas (Ladlie, 1991).

A modificaçāo no sítio de açāo do herbicida (ACCase) é um fator muito importante na resistência aos herbicidas. A atividade ACCase de plantas suscetiveis é inibida pelos herbicidas APP e CHD, enquanto que a enzima procedente de plantas resistentes nāo é afetada pela açāo destes herbicidas (Walker et al., 1988: Hoppe, 1989).

Pesquisas sobre o mecanismo de resistência aos APP e CHD em Setaria viridis (Marles et al., 1993), Lolium rigidum (Tardif et al., 1993) e Avena sterilis (Maneechote et al., 1994) revelaram que formas alteradas da ACCase sāo muito menos sensiveis a estes herbicidas. 
Para a maioria dos biotipos de plantas daninhas resistentes aos APP e CHD, analisados até o momento, o caráter resistente é conferido por uma mutação na ACCase que reduz sua sensibilidade aos herbicidas. A resistência, nos casos estudados, está controlada por um só gen nuclear, dominante ou semidominante (Parker et al., 1999a; Betts et al., 1992 e Morrison et al., 1992), existindo em geral uma boa correlação entre o nivel de sensibilidade do local de ação in vitro e o grau de resistência que o biótipo apresenta in vivo. Ainda que nem sempre seja válido comparar dados derivados de diferentes biotipos, com os quais foram utilizados protocolos ligeiramente modificados, os padrōes de resistência apresentados pelos distintos biotipos resistentes caracterizados parecem indicar a existência de diversas mutaçōes na ACCase, capazes de proporcionar diferentes graus de resistência aos herbicidas APP e CHD (Devine, 1997). Desta maneira, é possivel identificar biotipos que apresentam resistência somente a determinados herbicidas APP, a APP e CHD ou somente CHD (Devine, 1997).

O desenvolvimento de resistência a herbicidas, foi verificado em populaçōes de Lolium multiflorum intensivamente tratadas com diclofop-methyl ou outros herbicidas APP e CHD. A resistência ao diclofop, no biotipo de $L$. multiflonum encontrado, foi correlacionada a uma ACCase insensivel a estes herbicidas (Shimabukuro \& Hoffer, 1991).

$\mathrm{O}$ uso repetido de graminicidas em monocultivo de trigo selecionou uma grande quantidade de biotipos de gramineas resistentes: dois biotipos de Lolium multiflorum (Gronwald et al., 1989 e Giménez-Espinosa et al., 1993); numerosos biotipos resistentes de Avena fatua (Heap et al., 1993); um biotipo de Lolium rigidum (Tardif et al., 1993); um biotipo de Avena sterilis (Mansooji et al., 1992); biotipos de Setaria spp. (Stoltenberg \& Wiederholt, 1993); um biotipo de Sorghum halepense (Smeda et al., 1993) e um biotipo de Eleusine indica (Marshall et al., 1994). O estudo dos valores de $I_{50}$ de herbicidas APP e CHD (concentração de herbicida necessária para inibir 50\% da atividade da ACCase in vitro para alguns destes biotipos) tem mostrado que existe uma ACCase mais resistente que a existente nos biotipos suscetiveis. A redução de afinidade entre o herbicida e seu local de ação se explica pela 
modificação no nivel do local de encaixe da ACCase, ainda que não se tenha determinado onde se localiza o gen mutacionado, ou por gens mutacionados, como é o caso de resistência a herbicidas inibidores fotossintéticos.

Para os estudos dos mecanismos de ação de biotipo resistente de $B$. plantaginea, optou-se por utilizar o herbicida sethoxydim, principal representante da família dos $\mathrm{CHD}$, por causa do alto fator de resistência obtido com este herbicida nos biotipos resistentes estudados no Capitulo III, além de ter sido o primeiro herbicida CHD amplamente utilizado em todo o mundo, o primeiro e mais intensivamente utilizado, graminicida seletivo à cultura de soja, no Brasil.

O herbicida sethoxydim è um CHD de aplicação em pósemergência, com atividade sistêmica e alta translocação pelo xilema e floema. Foi introduzido no Brasil no início da década de 80 pela Basf S.A. De rápida absorção via foliar, aplicado em cobertura total das plantas daninhas e da cultura; requer a adição de óleo mineral como adjuvante e um periodo mínimo de uma hora sem chuva após a aplicação. Controla principalmente monocotiledôneas anuais em culturas de soja, feijão, algodão e girassol, entre outras. A dose recomendada de ingrediente ativo é de 1,25 $\mathrm{kg} \mathrm{ha}^{-1}$, com volume de calda para aplicação entre 100 e $300 \mathrm{~L} \mathrm{ha}^{-1}$, sendo o momento ideal para tratamento quando as plantas daninhas apresentam entre 2-4 folhas e 20 a 25 dias após a semeadura da cultura (Rodrigues \& Almeida, 1998).

A necessidade de controle seletivo de uma grande variedade de monocotiledôneas tem originado a introdução de novos herbicids graminicidas capazes de controlar gramineas em culturas dicotiledôneas em baixas doses, e que talvez possam servir de alternativa ao uso de sethoxydim em áreas onde foram identificados problemas de resistência. O CHD tepraloxydim é um herbicida de aplicação em pós-emergência em fase de registro no Brasil, sendo porém já utilizado na Europa. É especialmente indicado para o controle de gramineas (perenes e anuais), em culturas de soja, algodão, beterraba, brássicas, canola e girassol. De grande atividade, é facilmente absorvido por via foliar translocando-se em toda a planta até os pontos de crescimento. As doses recomendadas variam de 50 a $100 \mathrm{~g}$ i.a. ha-1, com recomendação de 
volume de calda para aplicação de $200 \mathrm{~L} \mathrm{ha}{ }^{-1}$, devendo sempre ser utilizado junto com o adjuvante especifico. Os sintomas de fitotoxicidade mais evidentes nas espécies sensiveis sāo: paralizaçāo no crescimento das plantas, amarelecimento de folhas jovens entre 5 e 10 dias após a aplicação e coloraçāo avermelhada em algumas espécies de gramineas. O periodo ideal para tratamento das plantas daninhas com tepraloxydim em pós-emergência iniciase quando as plantas apresentam folhas entre quatro e seis folhas verdadeiras, indo até o final do perfilhamento (Boletim Basf Alemanha').

O objetivo do trabalho apresentado neste capitulo foi estudar as possiveis diferenças entre os biotipos $\mathrm{R}$ e $\mathrm{S}$ de $B$. plantaginea, que justificam o comportamento resistente frente aos herbicidas inibidores da ACCase. Para isso, foram utilizados os herbicidas sethoxydim e tepraloxydim com as moléculas marcadas com $\left[{ }^{14} \mathrm{C}\right]$.

A caracterizaçāo do mecanismo de resistência se efetuou com base nos seguintes aspectos:

- Estudo dos processos de absorção e translocaçāo nos biotipos R e S de $B$. plantaginea;

- Estudo da ACCase de ambos biotipos como possivel local de ação primário do sethoxydim e do tepraloxydim.

1 BASF Artiengesellschaft Plant Protection Product: Draft label text for the combinations product BAS 620-H plus Dash HC. September, 1998.12p. 


\section{MATERIAL E MÉTODOS}

\subsection{Absorção e translocação de herbicidas CHD em biotipos de $B$. plantaginea}

\subsubsection{Local}

Os estudos dos mecanismos de resistencia a herbicidas inibidores da ACCase em B. plantaginea foram baseados nos trabalhos de De Prado et al. (1991), Menendez et al. (1994) e Menendez \& De Prado (1996 e 1997).

Os experimentos foram conduzidos nos laboratórios e instalaçōes do Departamento de Quimica Agricola y Edafologia, da Escuela Técnica Superior de Ingenieros Agrónomos y de Montes, da Universidade de Córdoba, na Espanha.

\subsubsection{Material vegetal}

As sementes de biotipos de B. plantaginea, resistentes $\mathrm{e}$ suscetiveis, foram previamente tratadas para a quebra de dormência (Capitulo 3 - item 2.2). Em seguida, foram semeadas separadamente em bandejas de 35 x 50 x $5 \mathrm{~cm}$, contendo areia e matéria orgānica na proporçāo $1: 1$, cobertas com plástico para acelerar o processo de germinaçāo. As bandejas foram mantidas em uma cāmara de crescimento com temperatura dia/noite de $32 / 18^{\circ} \mathrm{C}$, fotoperiodo de $18 \mathrm{~h}$ de luz ( $\left.350 \mu \mathrm{mol} \mathrm{m}^{-2} \mathrm{~s}^{-1}\right)$ e umidade relativa constante de $80 \%$, irrigando-se diariamente, visando a manutençāo de umidade satisfatória.

Até aqui, a forma de obtençāo das plântulas foi a mesma para os ensaios de absorçāo/translocaçāo e atividade da ACCase.

Para os ensaios de absorçāo e translocaçāo, realizou-se o transplante aos sete dias após a semeadura, para vasos plásticos com capacidade de $200 \mathrm{~mL}$, contendo substrato à base de areia e matéria orgânica na proporçāo de 2:1 (Tabela 1). Estabeleceu-se a densidade de quatro plantas 
por vaso. Após o transplante os vasos foram regados, com uma solução a $0,5 \mathrm{~g}$ $\mathrm{L}^{-1}$ de fertilizante, contendo $20 \%$ de $\mathrm{N}, 20 \%$ de $\mathrm{P}_{2} \mathrm{O}_{5}$ e $20 \%$ de $\mathrm{K}_{2} \mathrm{O}$. As plantas foram mantidas em câmara de crescimento nas condiçōes anteriormente descritas até a sua utilização nos ensaios de absorção e translocação.

Tabela 1. Composição do substrato utilizado nos bioensaios com biotipos de $B$. plantaginea, em câmara de crescimento.

(\%) $\quad$ pH

\begin{tabular}{cccccccc}
\hline M.O. & $\mathbf{P}_{\mathbf{2}} \mathbf{O}_{\mathbf{5}}$ & $\mathbf{K}_{\mathbf{2}} \mathbf{O}$ & $\mathbf{C a}$ & $\mathbf{M g O}$ & $\mathbf{N}_{\text {orgânico }}$ & $\mathbf{F e}$ & $\left(\mathbf{H}_{\mathbf{2}} \mathbf{O}\right)$ \\
\hline 90 & 0,2 & 0,2 & 1 & 0,2 & 1,12 & 0,2 & 6,0 \\
\hline
\end{tabular}

Para os ensaios de atividade da ACCase, as plantas permaneceram nas bamdejas e foram regadas com a mesma solução fertilizante citada anteriormente. As plantas foram mantidas em câmara de crescimento nas mesmas condiçōes anteriormente descritas. Passados 20 dias após a semeadura foram cortadas a parte aérea das plantas que estavam no estádio de quatro a cinco folhas definitivas. O material vegetal assim obtido foi acondicionado em pacotes de papel aluminio contendo $3 \mathrm{~g}$ de plantas, e imediatamente mergulhados em nitrogênio liquido. Estas amostras permaneceram armazenadas em um “freezer” à temperatura de $-80^{\circ} \mathrm{C}$, até o momento de sua utilizaçã.

\subsubsection{Metodologia geral}

Os estudos de absorção e translocação de sethoxydim e tepraloxydim foram realizados com dois biotipos de $B$. plantaginea, sendo um suscetivel (S) e um resistente (R) (biotipo A do Capitulo 3). 
O método utilizado baseou-se na técnica de oxidação de amostras de partes da planta para quantificar a absorção e translocação em diferentes periodos após a aplicação dos herbicidas.

$\mathrm{Na}$ elaboração da solução para aplicação dos herbicidas, foram utilizadas moléculas radioativamente marcadas. Foram selecionados vasos dos biotipos $\mathrm{R}$ e $\mathrm{S}$ que apresentavam plantas uniformes e bem desenvolvidas, e com dois pares de folhas definitivas. As gotas da solução contendo herbicida foram depositadas sobre a superficie adaxial da segunda folha definitiva de cada planta, numa concentração de herbicida radioativo previamente calculada para se alcançar a quantidade de radiação desejada (especificadas nos próximos itens).

A absorção e translocação dos herbicidas foram estudadas em diferentes periodos após aplicação do herbicida (3, 6, 12, 24 e 48 horas). Após decorrido cada periodo, as plantas foram retiradas dos vasos e divididas em três partes (raizes, folha tratada e parte aérea) com o objetivo de quantificar a radioatividade em cada uma delas. As folhas tratadas foram lavadas com $5 \mathrm{~mL}$ de metanol a $80 \%$, para eliminar o herbicida não absorvido. O metanol utilizado na lavagem das folhas (liquido de lavagem) foi misturado com líquido de cintilação e levados para posterior medição da radioatividade residual. As outras partes da planta (raízes e parte aérea restante) foram colocadas em cones de celulose Packard e levadas para secar em estufa a $60{ }^{\circ} \mathrm{C}$, durante 48 horas. Após este periodo as amostras foram submetidas a combustão em um oxidador Packard Sample Oxydizer Modelo 307.

A combustão se realizou em uma atmosfera rica em oxigênio (oxidação), de forma que todo o [ $\left.{ }^{14} \mathrm{C}\right]$ presente nas amostras passasse a $\left[{ }^{14} \mathrm{CO}_{2}\right]$ (De Prado et al., 1990 e 1993; Giménez-Espinosa, 1997 e Menendez, 1997). O $\left[{ }^{14} \mathrm{CO}_{2}\right]$ desprendido passou através de uma coluna que continha "Carbosorb" como suporte, substāncia capaz de retê-lo e transformá-lo em carbamato. As amostras de carbamato resultantes de cada tratamento foram coletadas individualmente e adicionadas a $5 \mathrm{~mL}$ de liquido de cintilação (Permafluor). A radioatividade contida neste meio foi posteriormente medida num espectômetro de cintilação líquida, modelo Beckman LS 6000 TA. 


\subsubsection{Tratamentos com sethoxydim}

Nos ensaios de absorçāo e translocaçāo foram estudadas as possiveis diferenças na absorçāo e movimentaçāo do sethoxydim entre os biotipos R e S. Para isso, foi utilizada uma mistura composta de $\left[{ }^{14} \mathrm{C}\right]-$

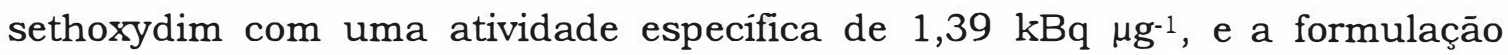
comercial Poast na concentraçāo de $184 \mathrm{~g} \mathrm{~L}^{-1}$ de i.a., na qual foi adicionado $0,5 \%$ (v:v) de óleo mineral (surfactante).

A concentraçāo final de sethoxydim na soluçāo aplicada foi correspondente à dose de campo recomendada de $368 \mathrm{~g}^{\mathrm{ha}^{-1}}$ de i. a. (equivalente a 2,0 L ha-1 do produto comercial) em um volume de aplicaçāo de $200 \mathrm{~L} \mathrm{ha}^{-1}$ de soluçāo.

A concentraçāo final de sethoxydim radiomarcado na soluçāo foi correspondente a $1,37 \mathrm{MBq} \mu \mathrm{L}^{-1}$, e a quantidade total de radioatividade aplicada por planta foi de $2,74 \mathrm{MBq}$, tanto para os ensaios de absorçāo como para os de translocaçāo.

A soluçāo assim formulada foi aplicada sobre a segunda folha definitiva das plantas dos biotipos $\mathrm{R}$ e $\mathrm{S}$, na forma de quatro micro gotas de 0,5 $\mu \mathrm{L}$ cada uma, usando um microaplicador (Hamilton PB 6000 Dispenser, Hamilton Co., Reno, NV).

Após a aplicação do herbicida, a absorção e a translocação foram estudadas em diferentes periodos $(3,6,12,24$ e 48 horas), nos quais as plantas permaneceram incubadas em câmara de crescimento, nas condiçōes citadas no item 2.2. Cumprido cada periodo de incubaçāo, as plantas foram divididas e levadas para combustāo, conforme descrito no item 2.1.3.

O experimento foi conduzido em delineamento inteiramente casualizado, com quatro repetiçōes para cada periodo de incubaçāo avaliado, para os biotipos R e S. O experimento foi repetido três vezes. 


\subsubsection{Tratamentos com tepraloxydim}

Nos ensaios de absorçāo e translocaçāo foram estudadas as possiveis diferenças na absorçāo e translocaçāo do tepraloxydim entre os biotipos R e S. Para isso, foi utilizada uma mistura composta de $\left[{ }^{14} \mathrm{C}\right]-$ tepraloxydim com uma atividade específica de $1,39 \mathrm{kBq}^{\mu-1}$, e a formulaçāo BAS $620 \mathrm{H}$ na concentraçāo de $200 \mathrm{~g} \mathrm{~L}^{-1}$ de i.a., na qual foi adicionado o adjuvante Dash na proporçāo de 1:4 (v:v) de herbicida.

A concentraçāo final de tepraloxydim na soluçāo aplicada foi correspondente a dose de campo recomendada de $50 \mathrm{~g} \mathrm{ha}^{-1} \mathrm{de}$ i. a. (equivalente a $0,25 \mathrm{~L} \mathrm{ha}^{-1}$ do produto comercial) em um volume de aplicaçāo de $200 \mathrm{~L} \mathrm{ha}^{-1}$ de soluçāo.

A concentraçāo final de tepraloxydim radiomarcado na soluçāo foi correspondente a $594 \mathrm{kBq} \mu \mathrm{L}^{-1}$, e a quantidade total de radioatividade aplicada por planta foi de $1,19 \mathrm{MBq}$, tanto para os ensaios de absorçāo como para os de translocaçāo.

A soluçāo assim formulada foi aplicada sobre a segunda folha definitiva das plantas dos biotipos $\mathrm{R}$ e $\mathrm{S}$, na forma de quatro micro gotas de $0,5 \mu \mathrm{L}$ cada uma, usando um microaplicador (Hamilton PB 6000 Dispenser, Hamilton Co., Reno, NV).

Após a aplicaçāo do herbicida, a absorçāo e a translocaçāo foram

estudadas em diferentes periodos $(3,6,12,24$ e 48 horas), nos quais as plantas permaneceram incubadas em câmara de crescimento, nas condiçōes citadas no item 2.2. Cumprido cada periodo de incubaçāo, as plantas foram divididas e levadas para combustāo, conforme descrito no item 2.1.3.

$\mathrm{O}$ experimento foi conduzido em delineamento inteiramente casualizado, com quatro repetiçōes para cada periodo de incubaçāo, para os biotipos R e S. O experimento foi repetido três vezes. 


\subsubsection{Análise dos dados}

A quantidade de herbicida absorvida foi determinada como sendo a porcentagem da radioatividade presente no interior da planta (soma da radioatividade liberada pelas diferentes partes: raizes + folha tratada + parte aérea) em relação à radioatividade total recuperada (radioatividade presente no liquido de lavagem + radioatividade total presente no interior da planta).

A taxa de absorção foi calculada medindo-se a radioatividade liberada pela combustão das amostras e a radioatividade no liquido de lavagem, sendo expressa como a porcentagem da radioatividade recuperada, segundo a fórmula:

Taxa de absorção $(\%)=\frac{\left[{ }^{14} \mathrm{C}\right] \text { tecido vegetal queimado }}{\left[{ }^{14} \mathrm{C}\right] \text { tecido vegetal queimado }+\left[{ }^{14} \mathrm{C}\right] \text { líq. lavagem folhas }} \times 100$

A translocação foi calculada pela porcentagem da radioatividade presente em cada parte da planta em relaçāo à radioatividade total aplicada na planta.

Foram calculadas as médias obtidas nos três experimentos, tanto nos de absorçāo como nos de translocaçāo, e os respectivos erros padrōes.

\subsection{Atividade da ACCase em biotipos de B. plantaginea}

Os ensaios de atividade da ACCase realizados neste trabalho foram baseados nas metodologias utilizadas por Menendez \& De Prado (1996), as quais foram adaptadas de Gronwald et al. (1992).

Nestes ensaios foi realizada a extração da ACCase presente nas plantas de dois biotipos de $B$. plantaginea, um suscetivel (S) e um resistente (R), e avaliada a suscetibilidade da enzima aos herbicidas CHD, sethoxydim e 
tepraloxydim, visando conhecer a origem da diferença de tolerância destes biotipos a estes herbicidas. A medida da atividade enzimática foi realizada através da radioatividade estável em meio ácido, após a reação com os herbicidas. Foram medidas a atividade da ACCase in vitro em cada uma das várias concentraçōes dos herbicidas testados, para os biotipos $\mathrm{R}$ e S.

\subsubsection{Extração da ACCase}

As plantas utilizadas para os estudos de atividade da ACCase foram obtidas conforme descrito no item 2.2. O material vegetal congelado foi retirado do "freezer" e imediatamente pulverizado com nitrogênio liquido em um pote de porcelana. O pó obtido foi homogeneizado a uma proporção de 1:3 (p:v) com uma solução tampão de extração [Hepes-KOH $0,1 \mathrm{M}(\mathrm{pH} 7,5)$, glicerol 0,5 M, $\mathrm{Na}_{2}$ EDTA $2 \mathrm{mM}$, DTT $5 \mathrm{mM}$ e PMSF 0,32 mM] durante dois minutos, usando um agitador magnético. O homogeneizado foi posteriormente filtrado através de quatro capas de "cheesecloth" e duas de Miracloth (Calbiochem) e centrifugado durante 30 minutos a $24.000 \mathrm{~g}$. O sobrenadante foi fracionado com sulfato de amônio, e o material precipitado a $50 \%$ sob agitador, durante 20 minutos. Esta solução foi centrifugada durante 15 minutos a $24.000 \mathrm{~g}$. Após retirado da centrífuga, desprezou-se o sobrenadante e o "pellet" resultante foi ressuspendido em $1 \mathrm{~mL}$ de solução tampão [Tricina-KOH 0,1 M (pH 8,3), glicerol 0,5 M, KCl 50 mM, Na 2 EDTA 2 mM e DTT 0,5 mM]. O "pellet" ressuspendido foi aplicado a uma minicoluna de $10 \mathrm{~mL}$ de Sephadex G-25, equilibrada com a solução tampão. As fraçōes foram eluídas utilizando a mesma solução tampão. Todo o processo de extração foi realizado em câmara fria à temperatura de $4{ }^{\circ} \mathrm{C}$.

\subsubsection{Bioatividade enzimática para sethoxydim e tepraloxydim}


O procedimento para estudo da atividade enzimática foi idêntico para os dois herbicidas, diferindo somente nas concentraçōes de sethoxydim e tepraloxydim utilizadas para compor a mistura de reaçāo.

A mistura de reaçāo foi composta de soluçāo tampāo [Tricina$\mathrm{KOH}$ 0,1 M (pH 8,3), glicerol 0,5 M, KCl 50 mM, Na ${ }_{2}$ EDTA 2 mM e DTT 0,5 $\mathrm{mM}$ ], ATP 3,75 mM, $\mathrm{MgCl}_{2} 50 \mathrm{mM}, \mathrm{NaH}\left[{ }^{14} \mathrm{CO}_{3}\right.$ ] (com atividade especifica de 2,1 MBq $\mu \mathrm{mol}^{-1}$ ) $15 \mathrm{mM}, 50 \mu \mathrm{L}$ de extrato vegetal, acetil-CoA $5 \mathrm{mM}$ e metanol com diferentes concentraçōes de ingrediente ativo do herbicida, totalizando um volume de $200 \mu \mathrm{L}$. A temperatura para a realizaçāo do ensaio foi $34^{\circ} \mathrm{C}$. Todos os componentes da mistura utilizada no ensaio, exceto o acetil-CoA, foram préincubados em banho-maria durante 1 minuto. Após este periodo, foi acrescentado o acetil-CoA para dar inicio a reaçāo. Passados 5 minutos, a reaçāo foi detida adicionando-se $30 \mu \mathrm{L}$ de $\mathrm{HCl} 4 \mathrm{~N}$. As amostras foram levadas para evaporar a $60^{\circ} \mathrm{C}$, sob uma corrente de nitrogênio gasoso, sendo posteriormente acrescentados $0,5 \mathrm{~mL}$ de etanol a $50 \%$ e $5 \mathrm{~mL}$ de líquido de cintilaçāo. A atividade enzimática das fraçōes obtidas foi determinada pela da incorporaçāo da radioatividade estável em meio ácido, presente após a reaçāo $\left(\mathrm{NaH}\left[{ }^{14} \mathrm{CO}_{3}\right]\right.$ incorporado à sintese de malonil-CoA). A radioatividade na forma de malonil-CoA foi determinada por um espectômetro de cintilaçāo liquida, modelo Beckman LS 6000 TA. Como teste em branco foi utilizada a mesma mistura de reaçāo sem acetil-CoA. Os experimentos foram conduzidos em delineamento inteiramente casualizado com quatro repetiçōes, para os biotipos $\mathrm{R}$ e $\mathrm{S}$, e repetidos quatro vezes.

\subsubsection{Análise dos dados}

Os valores de I $_{50}$ (concentraçāo de herbicida necessária para inibir $50 \%$ da atividade enzimática) para cada biotipo e herbicida testados foram determinados através de curvas onde foram plotados os valores de porcentagem de inibiçāo, obtidos nos experimentos, nas diferentes concentraçōes testadas. 


\section{RESUltados E discussāo}

\subsection{Absorçāo e translocaçāo de herbicidas CHD em biotipos de Brachiaria plantaginea}

Os herbicidas sethoxydim e tepraloxydim apresentaram por uma alta capacidade de absorçāo foliar. A porcentagem de sethoxydim absorvido foi aumentando com o passar do tempo, alcançando $69,3 \%$ no biotipo $\mathrm{S}$ e $87,3 \%$ no biotipo $R$, após 48 horas de incubaçāo (Tabela 1). O mesmo foi verificado com o tepraloxydim que apresentou, após 48 horas da aplicaçāo, 67,6\% e $65,2 \%$ de absorçāo para os biotipos $\mathrm{R}$ e $\mathrm{S}$, respectivamente (Tabela 1).

Foram observadas maiores diferenças na absorçāo entre os biotipos $\mathrm{R}$ e $\mathrm{S}$, em relaçāo ao herbicida sethoxydim, durante o periodo observado. Porém, para o herbicida tepraloxydim, os biotipos $R$ e $S$ apresentaram absorções equivalentes (Figura 1).

A cinética do processo de absorçāo do sethoxydim mostra um aumento continuo na quantidade de herbicida absorvido até 6 horas após a aplicaçāo, para o R, e até 12 horas após a aplicação para o biotipo S (Figura 1). Posteriormente, a quantidade de sethoxydim presente no tecido foliar se estabiliza para o biotipo resistente, alcançando às 12 horas da aplicaçāo o valor máximo absorvido de $70,6 \%$ do herbicida aplicado; e para o biotipo suscetivel, alcançando às 48 horas da aplicaçāo alcançou o valor máximo absorvido de $87,3 \%$ do herbicida aplicado (Tabela 1). O herbicida sethoxydim apresentou uma aumento na absorçāo pelo biotipo $S$, a partir das 6 horas da aplicaçāo. Este efeito, ainda que em menor grau, também foi observado com o herbicida tepraloxydim (Figura 1).

A cinética do processo de absorçāo do tepraloxydim mostra um aumento contínuo e mais rápido, em relaçāo ao sethoxydim, na quantidade de herbicida absorvido até 6 horas após a aplicaçāo, para os biotipos $R$ e $S$ 
Tabela 1. Absorção foliar de herbicidas CHD marcados com $\left[{ }^{14} \mathrm{C}\right]$, em biotipos de Brachiaria plantaginea.

\begin{tabular}{ccc}
\hline $\begin{array}{c}\text { Periodo de Incubaçāo } \\
\text { (horas) }\end{array}$ & \multicolumn{2}{c}{ sethoxydim (\% de [14C] recuperado) } \\
\cline { 2 - 3 } & Biotipo Resistente & Biotipo Suscetivel \\
\hline 3 & $78,3 \pm 1,5$ & $84,8 \pm 2,7$ \\
6 & $72,5 \pm 1,9$ & $73,8 \pm 2,6$ \\
12 & $70,6 \pm 1,9$ & $84,3 \pm 2,3$ \\
24 & $68,0 \pm 2,0$ & $76,4 \pm 1,5$ \\
48 & $69,3 \pm 1,9$ & $87,3 \pm 2,2$ \\
\hline
\end{tabular}

\begin{tabular}{ccc}
\hline $\begin{array}{c}\text { Periodo de Incubação } \\
\text { (horas) }\end{array}$ & \multicolumn{2}{c}{ tepraloxydim (\% de [14C] recuperado) } \\
\cline { 2 - 3 } & Biotipo Resistente & Biotipo Suscetivel \\
\hline 3 & $87,1 \pm 0,9$ & $87,1 \pm 0,3$ \\
6 & $80,4 \pm 1,7$ & $79,8 \pm 0,9$ \\
12 & $69,8 \pm 4,9$ & $73,5 \pm 2,6$ \\
24 & $67,2 \pm 13,4$ & $68,2 \pm 4,8$ \\
48 & $67,6 \pm 2,0$ & $65,2 \pm 3,5$
\end{tabular}

Nota: Os valores expressam médias de três experimentos, com os respectivos erros padrões.

(Figura 1). Posteriormente, a quantidade de tepraloxydim presente no tecido foliar se estabiliza, alcançando às 48 horas da aplicação os valores $67,6 \% \mathrm{e}$ $65,2 \%$ do herbicida aplicado nos biotipos resistente e suscetivel, respectivamente (Tabela 1 ). 


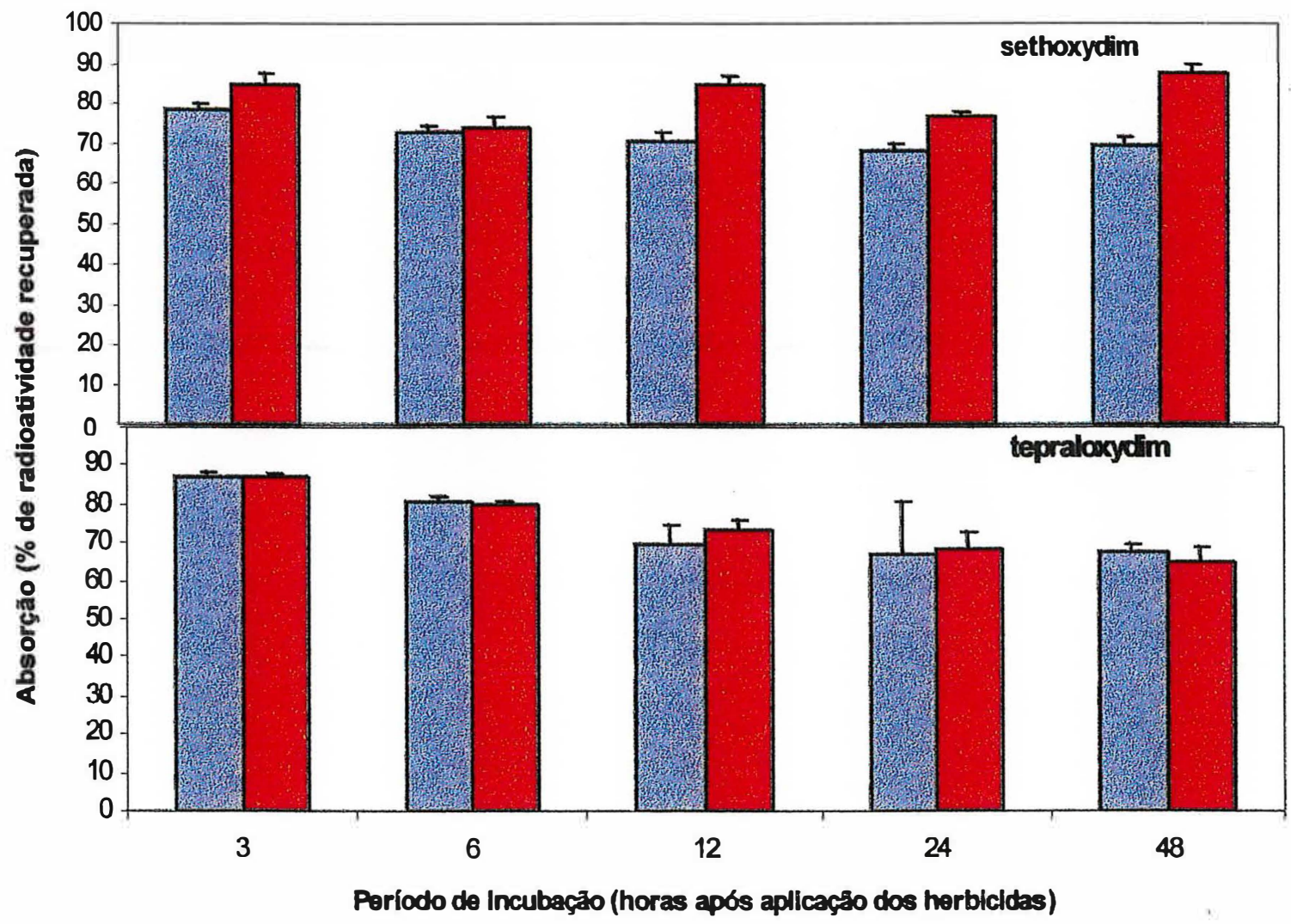

Resistente Suscetivel

Figura 1. Absorçāo foliar de herbicidas CHD radioativamente marcados, em biotipos de Brachiaria plantaginea. Os dados representam médias de três experimentos e as barras indicam os erros padrōes. 
Após a queima das diferentes partes das plantas em um oxidador, quantificou-se a radioatividade que continham, cujos resultados estão na Tabela 2.

Os herbicidas estudados apresentaram um padrão de translocação similar frente aos biotipos $\mathrm{R}$ e $\mathrm{S}$, caracterizado por uma acumulação máxima de radioatividade no tecido foliar durante as primeiras 12 horas, seguidos de uma lenta porém continua diminuição neste conteúdo conforme o herbicida se translocava para o restante da planta (Figuras 2 e 3 ).

Tanto o biotipo $\mathrm{R}$ como o $\mathrm{S}$ apresentaram uma distribuição similar dos herbicidas absorvidos, durante o periodo de incubação avaliados (Figuras 2 e 3).

A translocação de sethoxydim ocorreu seguindo o mesmo padrão em ambos biotipos $\mathrm{R}$ e S (Figura 2), ou seja, verificou-se uma diminuição na quantidade de herbicida na folha tratada após as primeiras 6 horas, para logo ir aumentando na parte aérea e raizes.

Para o herbicida tepraloxydim, a distribuição na folha tratada segue reduz-se até as 12 horas após a aplicação, aumentando a partir daí as quantidades na parte aérea e raizes (Figura 3).

Em termos absolutos, o herbicida sethoxydim foi o que apresentou maior efeito sistêmico com valores de herbicida translocado (\% da radioatividade aplicada que se detecta fora da regiāo de aplicação) situados entre $23,9 \%$ para o $\mathrm{R}$, e $27,2 \%$ para o $\mathrm{S}$, da radioatividade aplicada, transcorridas 24 horas da aplicação. Os valores mais altos de translocação até a raiz foram observados com o tepraloxydim (10,0\% para $\mathrm{R}$ e $10,7 \%$ para $\mathrm{S}$, da radioatividade aplicada) (Tabela 2). Assim, tepraloxydim foi o herbicida mais eficiente na mobilização a partir da área tratada (folhas) ao restante da planta (parte aérea e raiz) (Figura 3).

Os resultados obtidos indicam que a baixa sensibilidade do biotipo $R$ an sethnxydim, pnde ser de algiıma fnrma influenciada pela diminuição em sua capacidade de absorver o herbicida; porém as diferenças observadas não são suficientes para explicar a elevada taxa de resistência encontrada neste biotipo. 


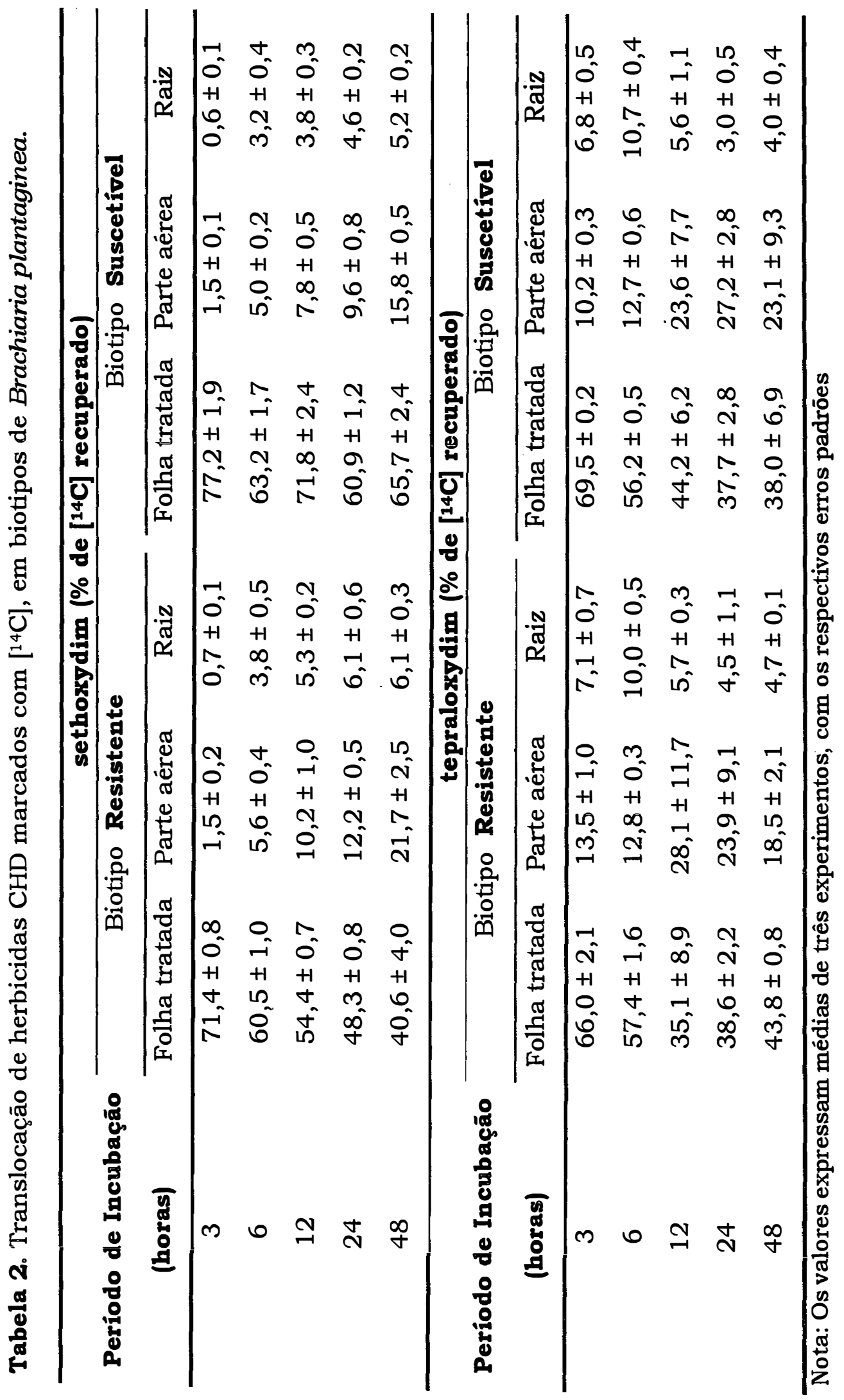




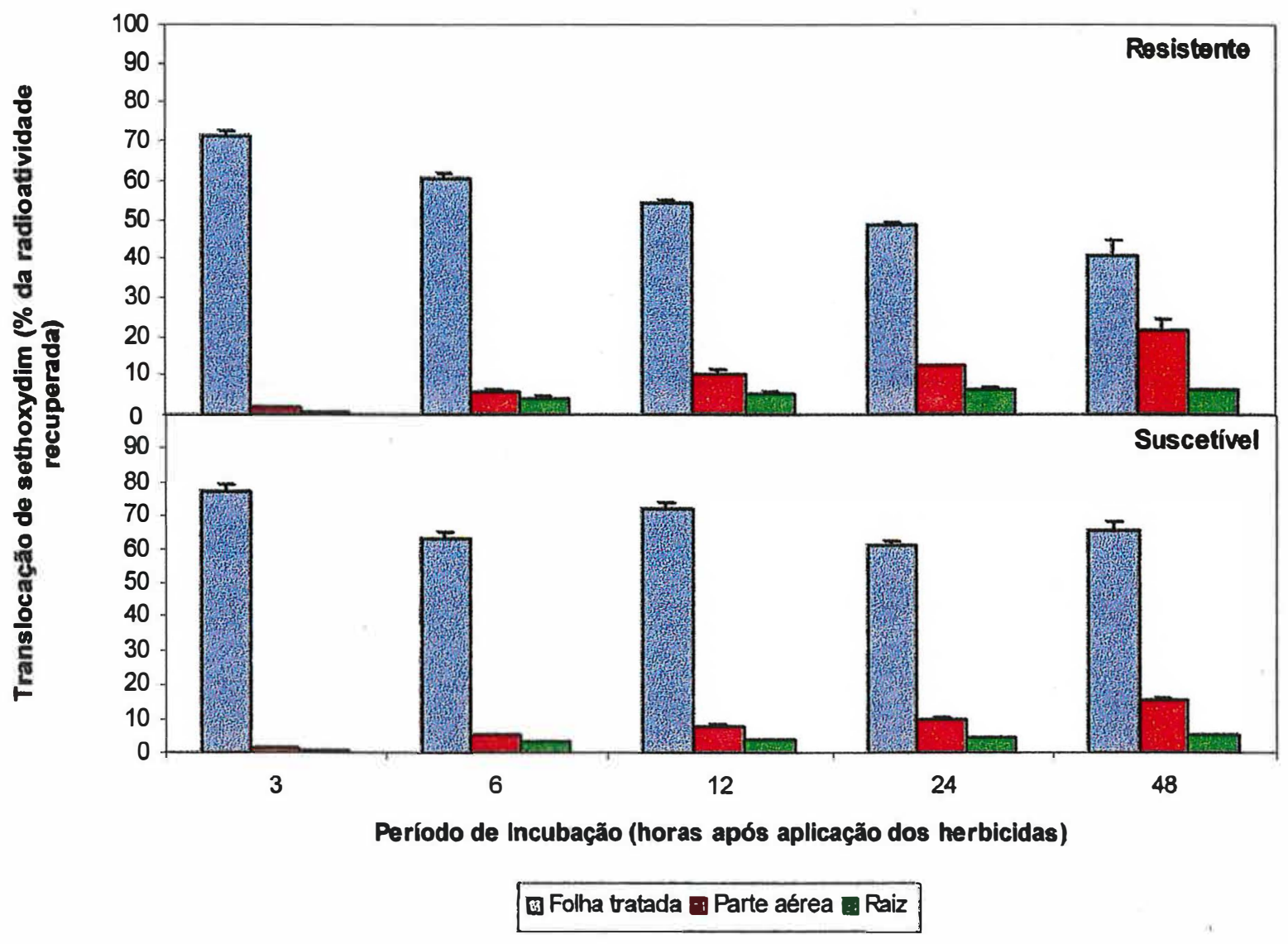

Figura 2. Translocaçāo do herbicida [14C]-sethoxydim em biotipos de Brachiaria plantaginea. Os dados representam médias de três experimentos e as barras indicam os erros padrōes. 


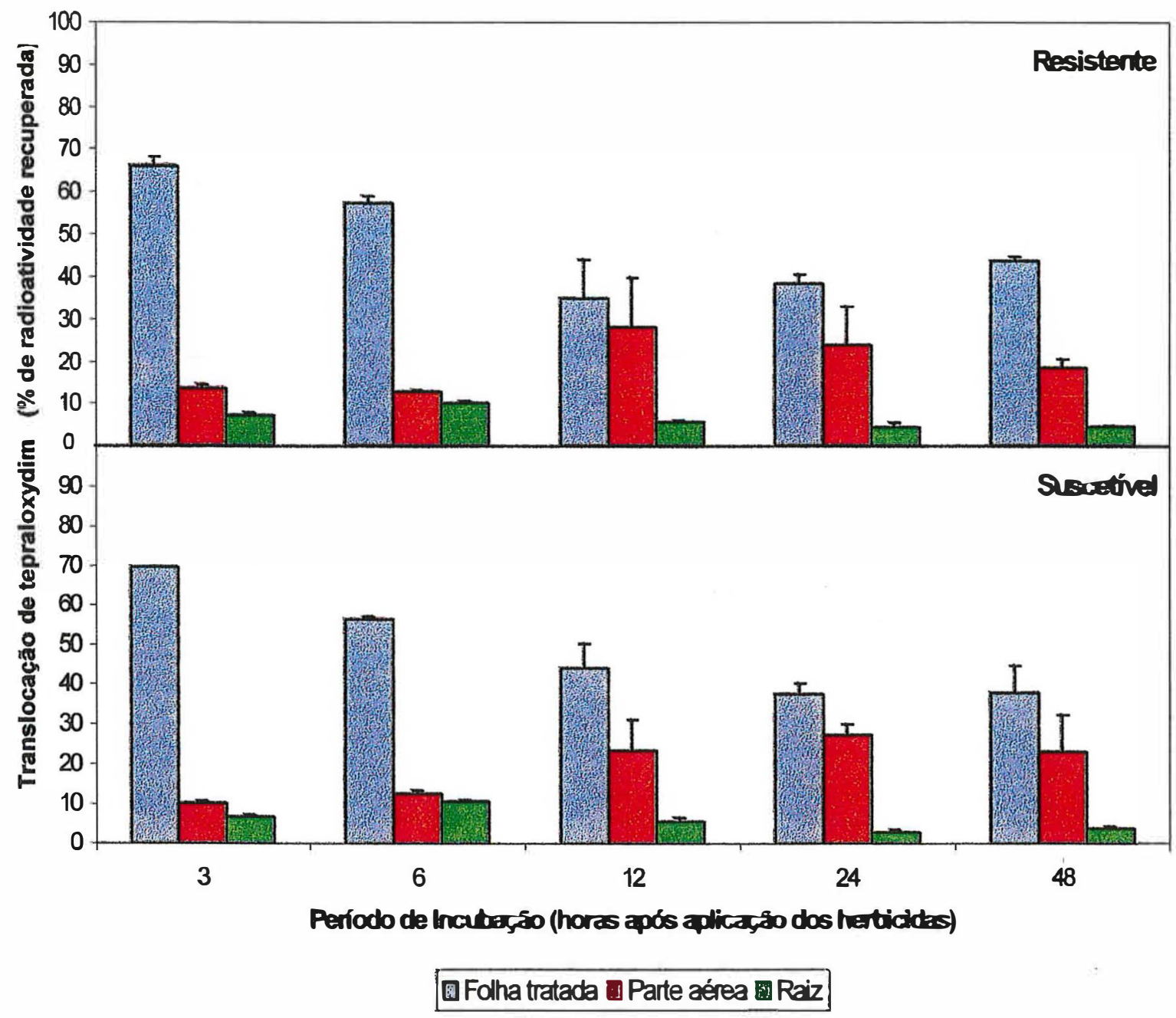

Figura 3. Translocaçāo do herbicida $\left[{ }^{14} \mathrm{C}\right]$-tepraloxydim em biotipos de Brachiaria plantaginea. Os dados representam médias de três experimentos e as barras indicam os erros padrões. 
A partir da análise dos casos estudados de absorção e wanslocação de sethoxydim realizados com várias espécies, como: Lolium multiflorum (Gronwald et al., 1992), Avena fatua (Heap et al., 1993) e Setaria viridis (Heap \& Morrisom, 1996 e Marles et al., 1993), constatou-se que a absorção de herbicida poucas horas após o ratamento foi alta, havendo uma rápida translocação do herbicida desde a folha tratada até o restante da planta, embora sem diferenças entre biotipos resistentes e suscetiveis. Nos casos dos biotipos de B. plantaginea, a absorção foi maior do que nas espécies citadas nestes trabalhos, porém com uma baixa translocação do herbicida, permanecendo a maior parte do tempo na folha tratada, após 48 horas da aplicação.

Nos ensaios realizados, ambos biotipos mostraram uma alta taxa de absorção dos herbicidas. Com estes resultados, acredita-se que os processos relacionados com a entrada dos herbicidas dentro da planta não contribuem de forma significativa para a diferente sensibilidade observada em ambos biotipos, tal como havia sido observado em alguns casos de biotipos de plantas daninhas resistentes a sethoxydim descritos até o momento (Wiederholt \& Stoltenberg, 1995; Stoltenberg \& Wiederholt, 1995; Hall et al., 1997).

\subsection{Atividade da ACCase em biotipos de Brachiaria plantaginea}

O estudo da atividade da ACCase procedente de folhas de $B$. plantaginea mostrou que existem diferenças nos valores de $\mathrm{I}_{50}$ entre os biotipos $\mathrm{R}$ e S estudados, para ambos herbicidas (Tabela 3).

Os herbicidas sethoxydim e tepraloxydim são potentes inibidores da ACCase e pertencem ao grupo quimico das ciclohexanodionas (CHD); no entanto, a análise da taxa de resistência para o biotipo $R$ sugere que é necessário uma dose de sethoxydim 216,7 vezes superior para se atingir os mesmos niveis de inibição na ACCase extraída de plantas do biotipo S. Para o tepraloxydim, verificou-se no biotipo $R$ a necessidade de uma dose 2,3 vezes superior para se obter o mesmo efeito de inibição da ACCase com o biotipo S. 
Tabela 3. Efeito de herbicidas CHD sobre a atividade da ACCase isolada de tecidos foliares de biotipos de Brachiaria plantaginea.

\begin{tabular}{cccc}
\hline Herbicida & \multicolumn{2}{c}{ I $_{50}(\boldsymbol{\mu M})^{(1)}$} & Taxa de \\
& Biotipo Resistente & Biotipo Suscetivel & Resistência(2) \\
\hline Sethoxydim & $650,0 \pm 28,9$ & $3,0 \pm 0,7$ & 216,7 \\
Tepraloxydim & $2,0 \pm 0,2$ & $0,9 \pm 0,2$ & 2,3 \\
\hline
\end{tabular}

(1) $\mathrm{I}_{50}=$ concentração de herbicida necessária para reduzir $50 \%$ da atividade da ACCase.

(2) Taxa de resistência $=I_{50}(R) / I_{50}(S)$

Nota: Os valores expressam médias de quatro experimentos, com os respectivos erros padrōes.

Em vários trabalhos realizados com a metodologia aqui utilizada observou-se que a ACCase de biotipos resistentes mostrou-se menos sensivel ao efeito inibidor dos herbicidas APP e CHD testados, de modo que as taxas de resistência obtidas para sethoxydim, em outras plantas daninhas têm sido, na maioria das vezes superior a 100 (Stoltemberg \& Wiederholt, 1995; Hall \& Powles, 1997 e Shukla et al., 1997).

Devine (1997) apresenta distintos resultados de taxas de resistência para sethoxydim, medidos em relação à inibição da ACCase, para Setaria viridis (423), Setaria faberi (192) e Avena fatua (105).

Embora os valores do fator de resistência sejam relativamente próximos em alguns casos, verifica-se que a atividade das ACCases ao sethoxydim (valores de $I_{50}$ ), tanto em biotipos resistentes quanto em biotipos suscetíveis, é bastante variável dependendo da espécie de planta estudada.

As concentraçōes referentes ao $I_{50}$ para o biotipo $S$ foram inferiores $(3,0 \mu \mathrm{M}$ para o sethoxydim e $0,9 \mu \mathrm{M}$ para o tepraloxydim) às concentrações referentes ao $I_{50}$ do biotipo $R \quad(650,0 \mu \mathrm{M}$ para o sethoxydim e 2,0 $\mu \mathrm{M}$ para o tepraloxydim). Isto mostra que a sensibilidade da ACCase presente no biotipo $\mathrm{R}$ manifesta-se igualmente no biotipo $\mathrm{S}$, porém diferentemente em relação ao herbicida estudado, embora pertencente ao mesmo grupo químico. Estes resuitados podem estar relacionados ao fato do sethoxydim ter sido um dos herbicidas selecionadores da resistência deste biotipo, no campo.

A ocorrência de uma ou mais mutações genéticas, no processo se seleção dos biotipos resistentes, podem ocasionar perda de afinidade do 
herbicida pelo local de ação (no caso a ACCase) (Devine \& Shimabukuro, 1994; Gronwald, 1994 e Saari et al., 1994. Para a maioria das plantas daninhas resistentes aos herbicidas APP e CHD estudadas até o momento, a resistência é conferida por uma mutação na ACCase que reduz a sensibilidade aos herbicidas (Betts et al., 1992; Morrison et al., 1992 e Parker et al., 1999). Há em geral, uma boa correlação entre a sensibilidade in vitro da ACCase e a taxa de resistência apresentada nos ensaios in vivo, como podem ser observados pelos resultados apresentados no Capitulo 3. Os diferentes padrões de resistência aos diferentes inibidores da ACCase parecem indicar que diferentes mutações podem estar envolvidas no desenvolvimento de biotipos resistentes (Devine, 1997).

A ocorrência desta capacidade de alteração no sitio de ação pode ser a base do futuro desenvolvimento de populaçōes resistentes ao tepraloxydim, e reafirma a dificuldade em se predizer a efetividade de novos herbicidas em biotipos que apresentem resistência cruzada por alteração na enzima, já que estes podem desenvolver resistência às novas moléculas, inclusive por breves periodos de tratamento continuo (Cornes et al., 1995).

Os valores da taxa de resistência encontrados na atividade da ACCase do biotipo $R$ podem estar relacionados aos valores encontrados para porcentagem de controle e redução de fitomassa recém colhida (Capitulo 3 Tabela 9/biotipo B). Os dados bioquimicos comprovam que a ACCase extraida das plantas resistentes de $B$. plantaginea apresentam menor sensibilidade aos herbicidas inibidores da ACCase, pertencentes ao grupo quimico CHD.

Comparando-se os resultados de inibição da ACCase isolada com os obtidos pela planta inteira (Capitulo 3 - Tabela 9/biotipo B), verifica-se que os valores de $\mathrm{GR}_{50}$ foram maiores que os observados para $\mathrm{I}_{50}$, de um mesmo herbicida. Isso ocorre possivelmente porque nos estudos in vitro ocorre um isolamento do fator envolvido no mecanismo de resistência (ACCase) que é analisado isoladamente. Nos bioensaios in vivo são medidos o efeito total dos possiveis mecanismo(s) causador(es) da resistência. Nos estudos in vivo os valores $\mathrm{GR}_{50}$ encontrados para as variáveis analisadas seriam a soma dos 
efeitos de sensibilidade da ACCase e diferenças na absorção dos herbicidas, verificadas entre os biotipos resistente e suscetivel.

\section{Conclusōes}

Nas condiçōes em que os experimentos foram realizados, os resultados obtidos permitem extrair as seguintes conclusōes:

- As diferenças na capacidade de absorção do sethoxydim e do tepraloxydim encontradas nos biotipos resistente e suscetivel de $B$. plantaginea não foram suficientes para justificar a ocorrência da resistência a estes herbicidas;

- O processo de translocação dos herbicidas pelas diferentes parte da planta parece não contribuir de maneira significativa na resistência aos herbicidas CHD, no biotipo estudado;

- Considerando a inibição da ACCase como o mecanismo de ação dos herbicidas CHD, o estudo da sensibilidade da ACCase ao sethoxydim mostrou diferenças significativas entre os biotipos resistente e suscetivel estudados. 


\section{REFERÊNCIAS BIBLIOGRÁFICAS}

AHRENS, W.H. (Ed.) Herbicide handbook. 7. ed. Champaign, WSSA, 1994. $352 p$.

BETTS, K.J.; EHLKE, N.J.; WYSE, D.L.; GRONWALD, J.W.; SOMMERS, D.A. Mechanism of inheritance of dicloflop resistance in Italian ryegrass (Lolium multiflorum). Weed Science, n.40, p.184-189, 1992.

BORGEOIS, L.; KENKEL, N.C.; MORRISON, I.N. Characterization of crossresistance patterns in acetyl-CoA carboxylase inhibitor resistance wild oat (Avena fatua). Weed Science, v.45, p.750-755. 1997

BROMILOW, R.H.; CHAMBERLAIN, K. Pathways and mechanisms of transport of herbicide in plants. In: KIRKWOOD, R.C., ed Targest sites for herbicides action. Plenum Press, Nueva York, p.245-284. 1991.

CORNES, D.W.; MILLS, C.E.; RYAN, P.J. Development and management of resistance to aryloxyphenoxypropionates in Alopecurus mysuroides in the UK. Proc. International Symp. Weed and Crop Resistance to Herbicides, Cordoba, Spain, p.229-230, 1995.

DE PRADO, R.; MENÉNDEZ, J.; TENA, M. Response to substituted ureas, triazines and chloroacetanilides in a biotype of Alopecurus myossuroides resistant to chlorotoluron. In: BRIGHTON CROP PROTECTION CONFERENCE - WEEDS. p. 1065-1070, 1991.

DE PRADO, R.; MENENDEZ, J.L. Cross-resistance and herbicide metabolism in Alopecurus myosuroides Huds. In: Regulation of Enzymatic System Detoxifying Xenobiotics in Plants (HATZIOS, K. K., ed.). Kluwer Academic Publisher, p. 351-366. 1997. 
DE PRADO, R.; ROMERA, E.; JORRIN, J. Effects of chloroacetamides and photosynthesis-inhibiting herbicides on growth and photosynthesis in sunflower (Helianthus annus L.) and Amaranthus hybridus L. Weed Research. n.33, p. 369-374, 1993b.

DEVINE, M.D. Mechanisms of resistance to acetyl coenzyme A carboxylase inhibitors: a review. Pesticide Science, v.51, p.259-264, 1997.

DEVINE, M.D.; McISAAC, S.A.; ROMANO, M.L.; HALL, J.C. Investigation of the Mechanism of Diclofop Resistance in Two Biotypes of Avena Fatua. Pesticide Biochemistry and Physiology, v.42, p.88-96, $1992 \mathrm{~b}$.

DEVINE, M.D.; SHIMABUKURO, R.H. Acetyl coenzyme A carboxylase inhibiting herbicides. In: POWLES, S.B. ; HOLTUM, J. A.M. eds Herbicide Resistance in Plants: Biology and Biochemistry, p.141-169. CRC Press, London. 1994.

DUKE, S.O.; KENYON, W. H. Polyciclic alkanoic acids. In: KEARNEY, P.C.; KAUFMAN, D.D. eds. Herbicides: Chemistry, Degradation, and Mode of Action Marcel Dekker, New York, p. 71-116. 1988.

GIMENEZ-ESPINOSA, M.R.M. Mecanimos de tolerência de garbanzo a piridato e y a los herbicidas ariloxifenoxipropionatos. Interacción entre la tolerância a herbicidas y la resistência a Fusarium oxysporum. Cordoba, 1997. 251p. (Tese Doutorado) - Escuela Técnica de Inginieros Agrônomos y de Montes - Universidad de Cordoba/Espanha.

GRONWALD, J.,W.; EBERLEIN, C.V.; BETTS, K.J.; ROSCOW, K.M.; EHLKE, N.J.; WYSE, D.L. Diclofop resistance in a biotype of Italian rye-grass. Plant Physiology 89 (Abstract no. 685), 115. 1989. 
GRONWALD, J.W. Herbicides inhibiting acetyl-CoA carboxylase. Biochemical Society Transactions, v. 22, n.3, p.616-621, 1994b.

GRONWALD, J.W.; EBERLEIN, C.V.; BETTS, K.J.; BAERG, R.J.; EHLKE, N.J.; WYSE, D.L. . Mechanism of diclofop resistance in na Italian ryegrass (Lolium multiflorum Lam.) biotype. Pesticide Biochemistry and Physiology, n. 44, p.126-139, 1992.

HALL, L.M.; TARDIFF, F.; POWLES, S.B. Mechanism of cross and multiple resistance in Alopecurus mysuroides and Lolium rigidum. Phytoprotecion, v. 73, p.17-23, 1994.

HEAP, I.M.; MORRISON, I. N. Resistance to aryloxyphenoxypropionate and cyclohexanodione herbicides in Green Foxtail (Setaria viridis). Weed Science, v.44, p.25-30. 1996.

HEAP, I.M.; MURRAY, B.G.; LOEPPKY, H.A.; MORRISON, I.N. Resistance to aryloxyphenoxypropionate and cyclohexanodione herbicides in wild oat (Avena fatua). Weed Science, v.41, p.232-238, 1993.

HOPPE, H.H. Fatty acid biosynthesis - a target site of herbicide action. In: BÖGER, P.; SANDMANN, G., eds Target sites of herbicide action, CRC Press, Boca Ration. p.65-83, 1989.

LADLIE, J.S. Guide to herbicide injury symptoms in soybeans with "look-alike" symptoms. Hollamdale: Agri-Growth Research, 1991, 86 p.

MANEECHOTE, C.; HOLTUM, J.M.; PRESTON, C.; POWLWS, S.B. Resistant acetyl-CoA carboxylse is a mechanism of herbicide resisitance in a biotype of Avena sterilis spp ludoviciana. Plant Cell Physiology, v.35, p.27-35, 1994. 
MANSOOJI, ${ }^{a}$ M.; HOLTUM, J. ${ }^{a}$ M.; BOUTSALIS,P.; MATTHEWS, J.M.; POWLRS, S.B. Resistance to aryloxyfhenoxypropionate herbicides in two wild oat species (Avena fatua and Avena sterilis). Weed Science, v.40, p.599-605, 1992.

MARLES, M.A.S.; DEVINE, M.D.; HALL, J.C. Herbicide resistance in Setaria viridis conferred by a less sensitive form of acetyl coenzyme A carbozylase. Pesticide Biochemistry and Physiology, v. 46, p.7-14, 1993.

MARSHALL G.; KIRKWOOD, R.C.; LEACH, G.E. Comparative studies on graminicide-resistant and susceptible biotypes of Eleusine indica. Weed Research, v. 34, n.3, p.177-185, 1994.

MENENDEZ, J.; DE PRADO, J.L.; DE PRADO, R. Diclofop metabolism in resistant biotypes of Lolium rigidum Gaudin. Proceedings of the International Symposium on Weed and Crop Resistance to Herbicide, Cordoba, Spain, 1996, p.97-98.

MENENDEZ, J. Mecanismos de resistência a herbicidas en biotipos de Alopecurus myosuroides huds. Cordoba, 1997. 246p. Tese (Doutorado) Escuela Técnica de Ingenieros Agrónomos y de Montes - Universdiad de Cordoba/Espanha.

MENENDEZ, J.; DE PRADO, R. Detoxification of chlorotoluron in a chlorotoluron - resistant biotype of Alopecurus myossuroides. Comparison between cell cultures and whole plants. Physiologia Plantarum. v.99, p.97-104, 1997.

MENENDEZ, J.; DE PRADO, R. Diclofop-methyl cross-resistance in a chlorotoluron resistant biotype of Alopecurus myossuroides. Pesticide Biochemistry and Physiology, v. 56, p.123-133, 1996. 
MENENDEZ, J.; JORRIN, J.; ROMERA, E.; DE PRADO, R. Resistance to chlorotoluron of a slender foxtail (Alopecunus myosuroides) biotype. Weed Science, v. 42, p. 340-353, 1994.

MORRISON, I.N.; BOURGEOIS, L. Approaches to managing ACCase inhibitor resistance in wild oat on the Canadian prairies. Proceedings of the Brighton Crop Protection Conference-Weeds, Brighton, England, p. 567576. 1995

PARKER, W.B.; MARSHALL, L.C.; BURTON, J.D.; SOMERS, D.A. WYSE, D.L.; GRONWALD, J.W.; GENGENBACH, B.G. Dominant mutations causing alterations in acetyl-Coenzyme. A carboxylase confer tolerance to cyclohexanedione and aryloxyphenoxypropionate herbicides in maize. Proc. Natl. Acad. Sci. USA, n.87, p.7175-7179. 1990a.

POWLES, S.B.; PRESTON, C. Herbicide cross resistance and multiple resistance in plants. Departament of crop protection. Waite Agricultural Research Institute. University of Adelaide. South Australia, 1995. 34 p.

RODRIGUES, B.N. e ALMEIDA, F.S. Guia de herbicidas. 4. ed. Londrina: IAPAR, 1998, 648p.

SAARI, L.L.; COTTEMAN, J.C.; THILL, D.C.. Resistance to acetolactate synthase inhibiting herbicides. In: Herbicide Resistance in Plants (Powles, S. B., y Holtum, J.A.M., CRC Press, Boca Raton, pp. 83-140. 1994

SHERMAN, T.D.; VAUGHN, K.C.; DUKE, S.O. Mechanism of action and resistance to herhicides. In DIIKF, S. $\cap$ (F.d.) Herhicides Resistant Crops. Boca Raton: CRC press, 1996. p.14-28. 
SHIMABUKURO, R.H. Selectivity and Mode of Action of the Postemergence Herbicide Diclofop-Methyl. Plant Growth Regul. Soc. Am. Q., v.18, p.3754, 1990.

SHIMABUKURO, R.H.; HOFFER, B.L.. Metabolism of diclofop-methyl in susceptible and resistant biotypes of Lolium rigidum. Pesticide Biochemistry and Physiology, v.39, p.251-258, 1991

SHUKLA, A.; DUPONT, S.; DEVINE, M.D. Resistance to ACCase-inhibitor herbicides in wild oat: evidence for target site-based resistance in two biotypes from Canada. Pesticide Biochemistry and Physiology, v.57, p.147-155, 1997.

SMEDA, R.J.; BARENTINE, W.L.; SNIPES, C.E. Johnsongrass (Sorghum halepense (L.) Pers.) resistence to postemergence grass herbicides. Weed Science Society of America. Abstract no. 53. 1993.

STOLTENBERG, D.E.; WIEDERHOLT, R.J. Giant foxtail (Setaria faberi Herm.) resistance to acetylCoA carbozylase inhibitors. Weed Science Society of America. Abstract no. 183. 1993.

TARDIF, F.J.; POWLES, S.B. Herbicide multiple-resistance in a Lolium rigidum biotype is endowed by multiple mechanisms: isolation of a subset with resistant acetyl-CoA carboxylase. Physiologia Plantarum, v.91, p.488494, 1994.

WALKER, K.A.; RIDLEY, S.M.; LEWIS, T.; HARWOOD, J.L. Fluazifop, a grass selective herbicide which inhibits acetyl-CoA carboxylase in sensitive plants species. Biochemistry Journal, v.254, p.307-310, 1988. 
WIEDERHOLT, R.J.; STOLTENBERG, D.E. Cross-resistance of a large crabgrass (Digitaria sanguinalis) accession to aryloxyphenypropionate and cyclohexanedione herbicides. Weed Technology, v.9, n.3, p.518-524, 1995. 


\section{CAPÍtULO V}

\section{ALTERNATIVA PARA O MANEJO AGRONÔMICO DE Brachiaria plantaginea (Link) Hitch. RESISTENTE A HERBICIDAS APP E CHD, EM PLANTIO DIRETO, NA CULTURA DA SOJA.}

RESUMO: Experimentos no campo e em casa-de-vegetação foram instalados com o objetivo de avaliar a eficácia de herbicidas inibidores da ACCase frente a herbicidas e misturas com outros mecanismos de ação, no controle de $B$. plantaginea resistente. $O$ controle da população resistente no campo foi ineficiente com os herbicidas inibidores da ACCase testados, porem o herbicida clethodim foi o que proporcionou maiores niveis de controle aos 28 dias após aplicação (DAA) no campo $(72,5 \%)$, e aos 14 DAA em casa-de-vegetação $(47,4 \%)$. O herbicida nicosulfuron proporcionou os maiores niveis de controle da B. plantaginea resistente, tanto no campo (72,5\% aos 28 DAA), quanto em casa-de-vegetação $(75,2 \%$ aos 14 DAA). No campo, a mistura trifluralin+nicosulfuron proporcionou o melhor controle $(75,0 \%$ aos 28 DAA). Apesar de não ser recomendado para a cultura da soja, o nicosulfuron e a mistura com trifluralin parecem representar uma alternativa de controle químico para populaçōes resistentes de $B$. plantaginea, desde que utilizados com a variedade de soja COOETEC-201, tolerante a este herbicida.

Palavras-chave: manejo da resistência, biotipos resistentes, resistência no campo. 
SUMMARY: Experiments under field and greenhouse conditions were conducted in order to evaluate the efficacy of ACCase inhibitor herbicides compared to isolated and mixtures of herbicide with other mechanism of action, on the control of resistant B. plantaginea. The control of the resistant population in the field was inefficient by the ACCase inhibitor herbicides tested, however, clethodim was the one with higher level of control at 28 days after treatment (DAT) in the field $(72.5 \%)$, and at 14 DAT in the greenhouse (47.7\%). The herbicide nicosulfuron gave the best control of de B. plantaginea, at field and greenhouse conditions $(72.5 \%$ at 28 DAT - field; $75.2 \%$ at 14 DAT greenhouse). In the field conditions, the mixture of trifluralin + nicosulfuron gave high level of control $(75.0 \%$ at 28 DAT). Even tough it is not recommended to be sprayed in soybean, nicosulfuron and the mixture with trifluralin seem to be a alternative to chemical control of resistant population of de $B$. plantaginea, if the variety of soybean.

Key words: resistant management, resistents biotypes, resistance in field.

\section{INTRODUÇÃO}

O capim-marmelada [Brachiaria plantaginea (Link) Hitchc.], codificada como BRAPL no código Internacional da WSSA, é uma das plantas daninhas anuais mais freqüentes nos solos cultivados das regiōes Centro e Sul do Brasil (Lorenzi, 1991). É particularmente importante na cultura da soja, possuindo alta capacidade competitiva, causadora de significativas perdas na produção.

A presença de plantas daninhas e a necessidade de se efetuar o controle são importantes fatores a serem considerados na cultura de soja, em razão destas plantas poderem causar perdas significativas das culturas conforme a espécie, a densidade e a distribuição na lavoura.

A presença de $B$. plantaginea em convivência com a cultura de soja pode provocar uma redução de $80 \%$ no rendimento final da cultura (Garcia et al., 1981). 
Vários trabalhos têm demonstrado a existência de um periodo, durante o ciclo da cultura de soja, no qual a interferência das plantas daninhas será determinante na reduçāo da produçāo e na qualidade dos grāos e sementes. Blanco et al. (1973) observaram que o periodo de competiçāo para a soja estava compreendido entre 45 e 60 dias após a germinação; para Maia \& Rafael (1978), este periodo situa-se entre 30 e 50 dias após a germinaçāo. Resultados máximos na produçāo de soja foram obtidos com o controle de plantas daninhas, realizado até os 40-50 dias após a germinaçāo da cultura (Durigan et al., 1983). Mesmo em condiçōes com alta infestaçāo (250 plantas $\mathrm{m}^{-2}$ de B. plantaginea) a competiçāo com a soja se estabeleceu a partir do $35^{\circ}$ dia após a emergência da cultura (Ministeri \& Melhorança, 1984).

Quando um campo é submetido a práticas normais de cultivo como a araçāo, a gradagem e a adubaçāo, a $B$. plantaginea emerge e, com a sua alta taxa de crescimento ocupa rapidamente a área disponivel, evitando a competiçāo com outras espécies (Carvalho, 1980).

Em geral, as maiores infestaçōes de B. plantaginea ocorrem durante os meses mais quentes e chuvosos do ano, geralmente entre setembro e dezembro (Alcántara \& Carvalho, 1982 e Lorenzi, 1991).

A sobrevivência de sementes no solo é um fator importante para o sucesso do estabelecimento de espécies anuais invasoras de áreas cultivadas. Ao final de vinte semanas, observou-se que aproximadamente $3 \%$ das sementes de $B$. plantaginea, enterradas no solo a $10 \mathrm{~cm}$ de profundidade, ainda permaneciam viáveis (Freitas, 1990). Desta forma, considerando a produtividade média de B. plantaginea. em torno de $670 \mathrm{~kg} \mathrm{ha}^{-1}$ (Whyte et al., 1975), após 20 semanas ainda são encontrados $500 \mathrm{~g}^{\text {ha-1 }}{ }^{-1}$ e sementes. Esta é, seguramente, uma quantidade de sementes suficiente para garantir a sobrevivência desta espécie no local.

No sistema de plantio direto da cultura de soja, tem-se encontrado maior dificuldade no manejo de $B$. plantaginea pois a presença da palhada proporciona um maior acúmulo de sementes no banco superficial do solo. No momento da semeadura, a abertura de pequenos sulcos promove um 
movimento de solo suficiente para que ocorra, nas linhas de plantio, uma considerável infestação (Kissmann, 1991).

Sementes produzidas durante o ano tendem a acumular-se na superficie do solo, onde germinam ou são incorporadas ao perfil do solo pelo manejo (Voll et al., 1995).

Entre as práticas agronômicas que influenciam a pressão de seleção e que geralmente são identificadas como desencadeadoras de fenômenos de resistência a herbicidas, pode-se destacar (Cussans, 1996): uso de monocultivo; adoção generalizada de um único sistema de cultivo (exemplo: plantio direto); uso massivo e exclusivo de herbicidas como única técnica de controle de plantas indesejáveis e dominância de um só herbicida, ou grupo de herbicidas, com o mesmo mecanismo de ação.

O uso de herbicidas tem sido uma prática eficiente no controle de plantas daninhas na soja, tendo como principal função reduzir a densidade ou a biomassa destas plantas, evitando que alcancem niveis capazes de causar danos por competição, na fase critica da cultura (Barros, 1989).

Existem diversos herbicidas na aplicação em pré-plantio e préemergência bastante eficazes para o controle de $B$. plantaginea. Porém, para o controle seletivo na cultura de soja, em aplicaçōes de pós-emergência, os herbicidas registrados no Brasil são restritos aos grupos químicos dos ariloxifenoxipropionatos (APP) e ciclohexanodionas (CHD). Condiçōes ambientais desfavoráveis ou deficiência nas tecnologia de aplicação podem ser responsáveis pelo controle deficiente. Somado a estes fatores, podemos acrescentar as dificuldades no manejo de populaçōes resistentes de $B$. plantaginea, dificultando ainda mais a eliminação da competição de plantas daninhas nesta cultura.

Outro fator limitante de grande importância é a falta de herbicidas graminicidas de aplicação em pós-emergência que controlem de forma efetiva as plantas daninhas ao longo do ciclo de cultivo. A soja, bem como a maioria das leguminosas é muito sensivel aos herbicidas aplicados em pós-emergência, e à competição com as plantas daninhas. 
Apesar da ampla informação disponivel sobre os fatores relacionados com a evolução das populaçōes de plantas daninhas resistentes a herbicidas, a capacidade para predizer onde e como estas populaçōes irão aparecer é ainda muito limitada (Moss, 1995 e Rubim, 1991). Em áreas agricolas dos Estados Unidos da América do Norte, Austrália e Europa, as densidades de plantas daninhas resistentes a herbicidas têm alcançado niveis que comprometem seriamente a produção, ou pelo menos obrigam a adoção de importantes alteraçōes nas práticas agricolas (Rubim, 1996). Diante desta situação tem-se buscado delinear e desenvolver programas que possam auxiliar o agricultor na luta contra as plantas daninhas resistentes a herbicidas (Mathews, 1994; Jutsum \& Graham, 1995; Morrison \& Bourgeois, 1995 e Shaner, 1995). Estes programas se baseiam no conceito de rotação como fator-chave na luta contra a resistência (Cussans, 1996): rotação de culturas; rotação das técnicas de manejo e rotação de herbicidas e em estratégias de manejo integrado de plantas daninhas.

Para prevenir o aparecimento e/ou controlar o crescimento de populaçōes resistentes de plantas daninhas aos herbicidas, é necessário modificar algumas práticas agricolas (Christoffoleti et al.,1994), como:

a) Uso de herbicidas alternativos: alguns herbicidas alternativos que ainda permanecem eficazes em populaçōes de plantas daninhas resistentes, pode ser uma estratégia de sucesso, pelo menos a curto prazo;

b) Uso de mistura de herbicidas: o uso de dois ou mais herbicidas com diferentes mecanismos de ação, aplicados como mistura de tanque ou de maneira seqüencial, devem reduzir a pressão de seleção do biotipo resistente. $O$ valor de tal estratégia depende da eficácia relativa de cada um dos herbicidas na planta daninha alvo e a especificidade dos mecanismos de resistência;

c) Manejo de herbicidas: a pressão de seleção será reduzida se forem usados herbicidas sem nenhuma ou pouca atividade residual no solo, assim como 
se forem reduzidas as doses de herbicidas e o número de aplicações a cada ano agricola;

d) Rotação de culturas: muitas espécies daninhas estão em sincronia com culturas específicas, assim, a rotação de culturas pode reduzir o sucesso intrinseco destas plantas e, em muitas situaçōes, permitir o uso de herbicidas alternativos.

É possivel observar que todas as recomendaçōes para prevençāo e controle de resistência de plantas daninhas aos herbicidas são baseadas na associação de medidas alternativas que auxiliam o controle químico das mesmas. Dessa forma, o manejo integrado no controle de plantas daninhas torna-se uma alternativa viável e eficiente no manejo da resistência.

O uso de herbicidas nos programas de manejo integrado de plantas daninhas tem como objetivo reduzir e racionalizar o uso de herbicidas, mediante o uso de rotação de herbicidas, manutenção dos niveis de infestação economicamente aceitáveis ou o tratamento localizado com herbicidas (Nordmeyer et al., 1996).

O uso de técnicas alternativas como a rotação de culturas, rotação de herbicidas e adoção de manejo integrado no controle de plantas daninhas (Brown \& Cotterman, 1994) representam importantes estratégias para evitar o aparecimento de resistência por parte das plantas. A adiçāo de sulfato de amônio à calda do herbicida pode melhorar a eficácia sobre as populaçōes de plantas daninhas resistentes. Algumas experiências com herbicidas alternativos e misturas com sulfato de amônio foram testadas, visando avaliar os efeitos sobre $B$. plantaginea resistente aos inibidores da ACCase.

Além da busca de novas alternativas que possam ser usadas no controle de biótipos de B. plantaginea resistente, foram estabelecidos como objetivos deste trabalho:

- Estudar a eficácia de alguns herbicidas e suas misturas sobre um biótipo resistente de B. plantaginea, em condiçōes de campo e de casa-de-vegetação; 
- Comparar a eficácia do controle de herbicidas inibidores da ACCase e de herbicidas alternativos com diferentes mecanismos de ação, no controle de um biótipo resistente de $B$. plantaginea, em condiçōes de campo e de casade-vegetação;

- Estudar a resposta a herbicidas alternativos, de uma cultivar de soja, em condiçōes de campo, como alternativa indireta de controle a plantas resistentes, a fim de propor vias alternativas de controle quimico.

\section{MATERIAL E MÉTODOS}

Foram realizados ensaios testando-se tratamentos quimicos alternativos para o controle de $B$. plantaginea resistente a herbicidas inibidores da ACCase isolada (em vasos, na casa-de-vegetação), e em convivência com a cultura da soja (no campo, em Guarapuava/PR).

Faltam no Brasil opçōes de herbicidas graminicidas seletivos, utilizados em pós-emergência na cultura de soja, assim os tratamentos utilizados aqui foram selecionados a partir de observaçōes realizadas pelo trabalho dos técnicos da Cooperativa Agrária Mista Entre Rios Ltda., que vinham utilizando adjuvantes na calda de aplicação destes herbicidas, visando melhorar a eficácia de controle.

\subsection{Avaliação da sensibilidade de biotipos de Brachiaria plantaginea a herbicidas alternativos em bioensaio de casa-de-vegetação}

\subsubsection{Local}

O experimento foi conduzido em casa-de-vegetação do Departamento de Produção Vegetal da Escola Superior de Agricultura "Luiz de Queiroz", da Universidade de São Paulo, Piracicaba/SP. 


\subsubsection{Material vegetal}

As sementes foram coletadas da mesma área produtora de soja, onde posteriormente foi instalado o ensaio de campo, após a colheita da soja da safra 96/97. As sementes foram coletadas de várias plantas que sobreviveram aos tratamentos com herbicidas inibidores da ACCase. Foram recolhidas as sementes presentes no solo, liberadas naturalmente pelas plantas, para garantir um bom estádio de maturidade fisiológica das mesmas. Nesta área, o manejo de plantas daninhas de folhas estreitas apresentava histórico de uso intensivo de herbicidas CHD, nos últimos anos (vide Tabela 1 - Capitulo 3)

As amostras de sementes foram secas ao ar, e depois purificadas para se fazer a separação de solo, retirar o material inerte e as sementes chochas. Depois, as sementes resistentes e as suscetiveis, provenientes de áreas nunca antes tratadas com herbicidas, foram testadas para se conhecer as condições de germinação e possivel necessidade do uso de técnicas para a quebra de dormência. Comprovada a ocorrência de dormência, utilizou-se a técnica imersão das sementes em ácido sulfúrico por 30 minutos, segundo a metodologia apresentada por Freitas et al., 1993.

As sementes resistentes $\mathrm{e}$ as suscetiveis foram semeadas separadas e diretamente em vasos plásticos com capacidade de $500 \mathrm{~mL}$, contendo substrato à base de solo e matéria orgânica, na proporção 3:1 (Tabela 1). Os vasos foram irrigados diariamente para a manutenção de umidade satisfatória. Foi realizado um desbaste aos nove dias após a semeadura visando manter a densidade de cinco plantas por vaso. Para receber os tratamentos com os herbicidas foram selecionados vasos com plantas de aspecto uniforme e iniciando em média, a emissão do primeiro perfilho. 


\subsubsection{Tratamentos}

Como delineamento experimental foram adotados blocos inteiramente casualizados com 26 tratamentos ( 2 biotipos, 11 herbicidas e 2 testemunhas) e quatro repetiçōes.

Os herbicidas foram pulverizados sobre a parte aérea das plantas, utilizando-se um pulverizador pressurizado com ar comprimido e instalado em laboratório, com ponta de pulverização do tipo leque (Teejet 80.03E), com jato calibrado na altura de $50 \mathrm{~cm}$ da superficie do alvo. Os herbicidas foram aplicados dissolvidos em água, em um volume de pulverização correspondente a $300 \mathrm{~L} \mathrm{ha}^{-1}$ de calda, numa pressão de $40 \mathrm{lb} \mathrm{pol}^{-2}$.

Tabela 1. Análises(1) química e granulométrica do substrato utilizado no bioensaio com populações de $B$. plantaginea, em casa-devegetação.

\begin{tabular}{|c|c|c|c|c|c|c|c|c|c|c|}
\hline \multirow{2}{*}{$\begin{array}{c}\mathrm{pH} \\
\mathrm{CaCl}_{2}\end{array}$} & \multirow{2}{*}{$\begin{array}{c}\text { M.O. } \\
(\mathrm{g} \mathrm{dm-3)}\end{array}$} & $\mathbf{P}$ & $\mathrm{S}^{-\mathrm{SO}_{4}}$ & $\mathbf{K}$ & $\mathbf{C a}$ & $\mathbf{M g}$ & $\mathbf{A l}$ & SB & $\mathbf{T}$ & \multirow{2}{*}{$\begin{array}{c}V \\
(\%)\end{array}$} \\
\hline & & \multicolumn{2}{|c|}{$\left(\mathrm{mg} \mathrm{dm}^{-3}\right)$} & \multicolumn{6}{|c|}{$\left(\mathrm{mmolc} \mathrm{dm}^{-3}\right)$} & \\
\hline 6,6 & 43 & 504 & 127 & 17,6 & 103 & 30 & 0 & 150,6 & 166,6 & 90 \\
\hline \multicolumn{7}{|c|}{ Areia (\%) } & Silte & Argila & \multirow{2}{*}{\multicolumn{2}{|c|}{$\begin{array}{c}\text { Classe } \\
\text { de Textura }\end{array}$}} \\
\hline Muito & Grossa & ossa & Média & Fina Mui & to Fina & Total & (\%) & (\%) & & \\
\hline & & 4 & 11 & 23 & 8 & 47 & 14 & 39 & & \\
\hline
\end{tabular}

(1) Resultados fornecidos pelo Laboratório de Análises de Solos do Departamento de Ciência do Solo - ESALQ/USP.

Após a pulverização, as plantas foram mantidas em casa-devegetação, sendo irrigadas diariamente diretamente no solo.

Os herbicidas utilizados nos tratamentos em pós-emergência e as espectivas doses e produto comercial utilizados estão descritos na Tabela 2. 


\subsubsection{Avaliaçōes}

No ensaio de casa-de-vegetação foram avaliados a porcentagem de controle visual aos 7 e 14 dias após a aplicação dos herbicidas (DAA), e a fitomassa recém colhida aos 15 DAA.

As avaliaçōes de controle de plantas daninhas foram efetuadas empregando-se escala visual, considerando-se $0 \%$ para nenhum controle e $100 \%$ para controle total, comparados à testemunha sem herbicida.

\subsubsection{Análise dos dados}

Os dados originais de porcentagem de controle e da produção de fitomassa recém-colhida, foram submetidos aos testes de Lilliefors (1967) para se verificar a normalidade dos mesmos, e ao teste de Barttlet (1937) para se verificar a homogeneidade das variâncias. Nos casos em que os dados nāo apresentavam distribuiçāo normal ou variâncias homogêneas, foram utilizadas transformaçōes nos dados, de acordo com a variável testada.

Os dados foram submetidos à análise de variância utilizando-se o programa $\mathrm{SAS}^{1}$. As médias significativas pelo teste de $\mathrm{F}$ a $5 \%$ de probabilidade (Tabela A3 - Anexo), foram diferenciadas pelo teste de Tukey a 5\% de significância.

2.2 Avaliação de herbicidas alternativos no controle de população resistente de Brachiaria plantaginea em condiçōes de campo

\subsubsection{Local}

O ensaio foi conduzido em área de uma fazenda particular (Fazenda Três Capões), municipio de Guarapuava, região sudoeste do Paraná,

\footnotetext{
${ }^{1}$ SAS - Statistical Analisys System Institute, Cary, NC (versão 6.0) 27512.
} 
cujo proprietário era cooperado da Cooperativa Agrária Mista Entre Rios Ltda., a qual participou na condução do experimento. Anteriormente, ensaios conduzidos em condiçōes controladas de casa-de-vegetação (Capitulo 3) permitiram comprovar a hipóteeque a infestação de $B$. plantaginea presente nesta área se tratava de população resistente a herbicidas inibidores da ACCase.

A comunidade de plantas daninhas na área era composta basicamente de $B$. plantaginea, cobrindo cerca de $80 \%$ do solo.

O ensaio foi instalado em área cultivada com a cultura de soja, onde o manejo de plantas daninhas de folhas estreitas vinha sendo feito há vários anos com os herbicidas inibidores da ACCase pertencentes ao grupo químico dos CHD, sendo que nos últimos anos, os niveis de controle obtidos vinham se mostrando muito abaixo do esperado.

O solo do tipo latosșolo vermelho apresentou após a análise química e granulométrica, os resultados expostos na Tabela 3.

Tabela 3. Análises(1) química e granulométrica do solo da área experimental. Guarapuava/PR - 1997.

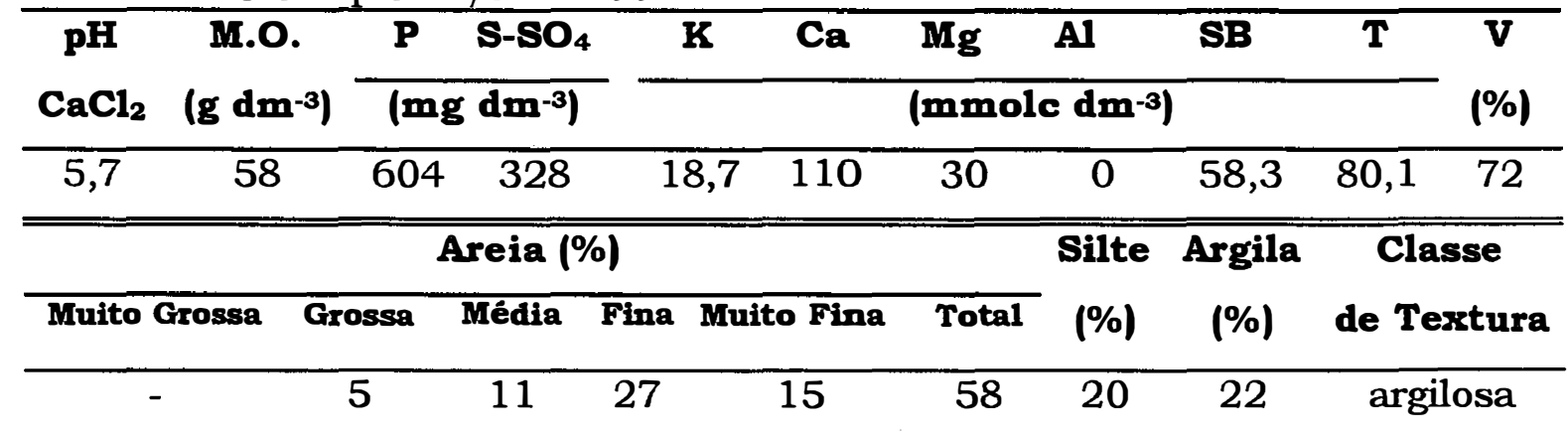

(1) Resultados fornecidos pelo Laboratório de Análises de Solos do Departamento de Ciência do Solo - ESALQ/USP.

\subsubsection{Tratamentos}

Como delineamento experimental foram adotados blocos casualizados com dez tratamentos e quatro repetições. As parcelas apresentavam 10 linhas de soja espaçadas de 0,5 m, com 7,0 m de 
comprimento, com uma área total de $35,0 \mathrm{~m}^{2}$, e $24,0 \mathrm{~m}^{2}$ de área útil. Os tratamentos utilizados no ensaio estão descritos na Tabela 4.

A pulverização de manejo foi realizada no dia 25 de setembro de 1997, empregando-se os herbicidas Roundup e Esteron nas dosagens de 1,5 L ha-1 e $0,5 \mathrm{~L} \mathrm{ha}^{-1}$, respectivamente, visando a eliminação da vegetação resultante do cultivo de trigo no inverno. Antes da semeadura da soja, foram aplicados ainda os herbicidas Zapp e Bladex nas dosagens de 1,25 $\mathrm{L} \mathrm{ha}^{-1}$ e 1,0 L ha-1 ${ }^{-1}$ respectivamente.

Tabela 4. Tratamentos utilizados no experimento de campo com a cultura de soja com infestação de $B$. plantaginea resistente a herbicidas inibidores da ACCase. Guarapuava/PR - 1997.

\begin{tabular}{|c|c|c|c|c|}
\hline \multicolumn{2}{|c|}{ HERBICIDAS } & \multirow{2}{*}{$\begin{array}{l}\text { Concentraçāo } \\
\text { de i.a. (1) g L -1 }\end{array}$} & \multirow{2}{*}{$\begin{array}{l}\text { Dose aplicada } \\
\text { L ha-1 de p.c.(2) }\end{array}$} & \multirow{2}{*}{$\begin{array}{l}\text { Época de } \\
\text { aplicação }\end{array}$} \\
\hline Nome comum & Nome comercial & & & \\
\hline sethoxydim(3) & Poast & 184 & 1,20 & $\mathrm{POS}(6)$ \\
\hline fluazifop & Fusilade & 125 & 1,50 & POS(6) \\
\hline fenoxaprop & Podium & 110 & 0,80 & POS(6) \\
\hline clethodim(4) & Select & 240 & 0,35 & $\operatorname{POS}(6)$ \\
\hline clethodim(4) + sulf. amônio & Select & 240 & $0,35+2 \%$ & $\mathrm{POS}^{(6)}$ \\
\hline nicosulfuron & Sanson & 40 & 1,50 & $\operatorname{POS}(6)$ \\
\hline trifluralin(5) + nicosulfuron & Premerlin + Sanson & $600+40$ & $2,50+0,75$ & $\operatorname{PRE}(\eta) / \operatorname{POS}(\theta)$ \\
\hline pendimethalin(5) & Herbadox & 500 & 3,00 & $\mathrm{PRE}^{n}$ \\
\hline Testemunha capinada & - & - & - & - \\
\hline Testemunha sem capina & - & - & - & - \\
\hline
\end{tabular}

Entre os tratamentos alternativos optou-se pela inclusão do herbicida nicosulfuron, apesar de não haver registro deste herbicida para a cultura de soja. Por esta razão, foi utilizada neste experimento a cultivar de soja COODETEC-201 por ser considerada tolerante ao herbicida nicosulfuron. 
A soja foi semeada em 18 de outubro de 1997, de forma mecânica, com espaçamento de $0,5 \mathrm{~m}$ entre linhas, colocando-se 18 sementes por metro linear, a uma profundidade de $3 \mathrm{~cm}$ da superficie do solo. Durante a semeadura realizou-se adubação na linha com $200 \mathrm{~kg} \mathrm{ha}^{-1}$ da förmula NPK + $\mathrm{Zn}$. As condiçōes climáticas após a semeadura caracterizaram-se por chuvas e temperaturas regulares.

A aplicação dos herbicidas em pré-emergência foi realizada aos oito dias após a semeadura da soja e os demais tratamentos 33 dias após a semeadura. Na operação de pulverização u tilizou-se um pulverizador costal de pressão constante e pressurizado com $\mathrm{CO}_{2}$, equipado com barra de 2,0 m de comprimento equipada com pontas de pulverização de jato leque Teejet 110.02, espaçadas de $0,5 \mathrm{~m}$ uma da outra. A pressão de trabalho foi de $28 \mathrm{lb} \mathrm{pol}^{-2}$ resultando num volume de aplicação de $210 \mathrm{~L} \mathrm{ha}^{-1}$. As condições ambientais no momento da aplicação dos herbicidas foram: temperatura de $23^{\circ} \mathrm{C}$, umidade relativa do ar no início da aplicação (09:30 horas) de 64\% e no final da aplicação (11:00 horas) de 52\%.

A $B$. plantaginea, que no momento da aplicação dos herbicidas encontrava-se na fase inicial de perfilhamento, apresentava uma densidade média de 336 planta $\mathrm{m}^{-2}$.

No momento da pulverização dos herbicidas de aplicaçāo em pósemergência, a cultura já apresentava o segundo trifólio. As condiçōes climáticas após a aplicação dos herbicidas, e durante a condução do ensaio, foram caracterizadas por chuvas e temperaturas regulares.

O tratamento testemunha capinada foi mantido no limpo durante todo o periodo de condução do ensaio, mediante capinas com enxada e arranquio manual das plantas daninhas.

Não foram necessárias aplicaçōes de outros agroquímicos para controle de pragas ou doenças, durante o ciclo da cultura. 


\subsubsection{Avaliaçōes}

Foram avaliadas a porcentagem de controle visual, a densidade de infestação de B. plantaginea e a fitotoxicidade dos herbicidas à cultura. A colheita da soja tornou-se impraticável por causa do abafamento da cultura, provocado pelo altíssimo nivel de infestação nas parcelas, que impediu de realizar a avaliação de produtividade da soja.

As avaliaçōes de controle de plantas daninhas foram efetuadas visualmente aos 7, 14 e 28 dias após a aplicação dos herbicidas (DAA), empregando-se escala visual de controle, considerando-se $0 \%$ para nenhum controle e $100 \%$ para controle total, comparados à testemunha sem capina.

A densidade de $B$. plantaginea foi avaliada aos 14 DAA mediante a contagem de plantas presentes dentro de um quadrado de 0,25 x 0,25 m (625 $\mathrm{cm}^{2}$ ), lançado três vezes aleatoriamente dentro das parcelas.

As avaliaçōes de fitotoxicidade foram realizadas aos 7, 14 e 28 DAA, de forma visual, utilizando-se escala percentual em que $0 \%$ equivale à ausência de danos ou sintomas fitotóxicos e 100\% a dano total ou morte da cultura, comparados à testemunha capinada.

\subsubsection{Análise dos dados}

No ensaio de campo foram avaliadas a porcentagem de controle visual aos 7, 14 e 28 dias após a aplicação dos herbicidas (DAA), a densidade de plantas de $B$. plantaginea aos 14 DAA e a fitotoxicidade à soja aos 7,14 e 28 DAA.

As avaliaçōes de controle de plantas daninhas foram efetuadas empregando-se escala visual, considerando-se $0 \%$ para nenhum controle e $100 \%$ para controle total, comparadns à testemunha sem herhirida.

Os dados originais de porcentagem de controle, densidade de plantas e fitotoxicidade foram submetidos aos testes de Lilliefors (1967) para se verificar a normalidade dos mesmos, e ao teste de Barttlet (1937) para se 
verificar a homogeneidade das variâncias. Nos casos em que os dados não apresentavam distribuição normal ou variâncias homogêneas, foram utilizadas transformações nos dados, de acordo com a variável testada.

Os dados foram submetidos à análise de variância utilizando-se o programa SAS 1 . As médias significativas pelo teste de $\mathrm{F}$ a $5 \%$ de probabilidade (vide Tabela A4 - Anexo) foram diferenciadas pelo teste de Tukey a 5\% de significância.

\section{RESULTADOS E DISCUSSĀO}

\subsection{Avaliaçāo da sensibilidade de biotipos de Brachiaria plantaginea a herbicidas alternativos em bioensaio de casa-de-vegetaçāo}

Os resultados de controle com herbicidas alternativos sobre biotipos resistente e suscetivel de $B$. plantaginea estão apresentados na Tabela 1.

$\mathrm{Na}$ avaliação inicial, os tratamentos testados não apresentaram diferenças significativas na eficácia de controle, nos biotipos testados. Porém, já no início das observações, verificou-se significativa diferença no controle médio obtido entre os biotipos resistente (R) e suscetivel (S). Aos 14 DAA, os tratamentos testados apresentaram uma distinta eficácia. Os herbicidas que melhor controlaram o biotipo $\mathrm{S}$ foram o fenoxaprop, seguido pelo sethoxydim. O herbicida nicosulfuron foi o que melhor controlou o biotipo $R$, com $75,2 \%$ de controle, embora estes valores tenham sido próximos aos obtidos com o biotipo S, com 70,2\%. Quando comparados entre si, o tratamento com nicosulfuron foi o único considerado equivalente para os dois biotipos. 


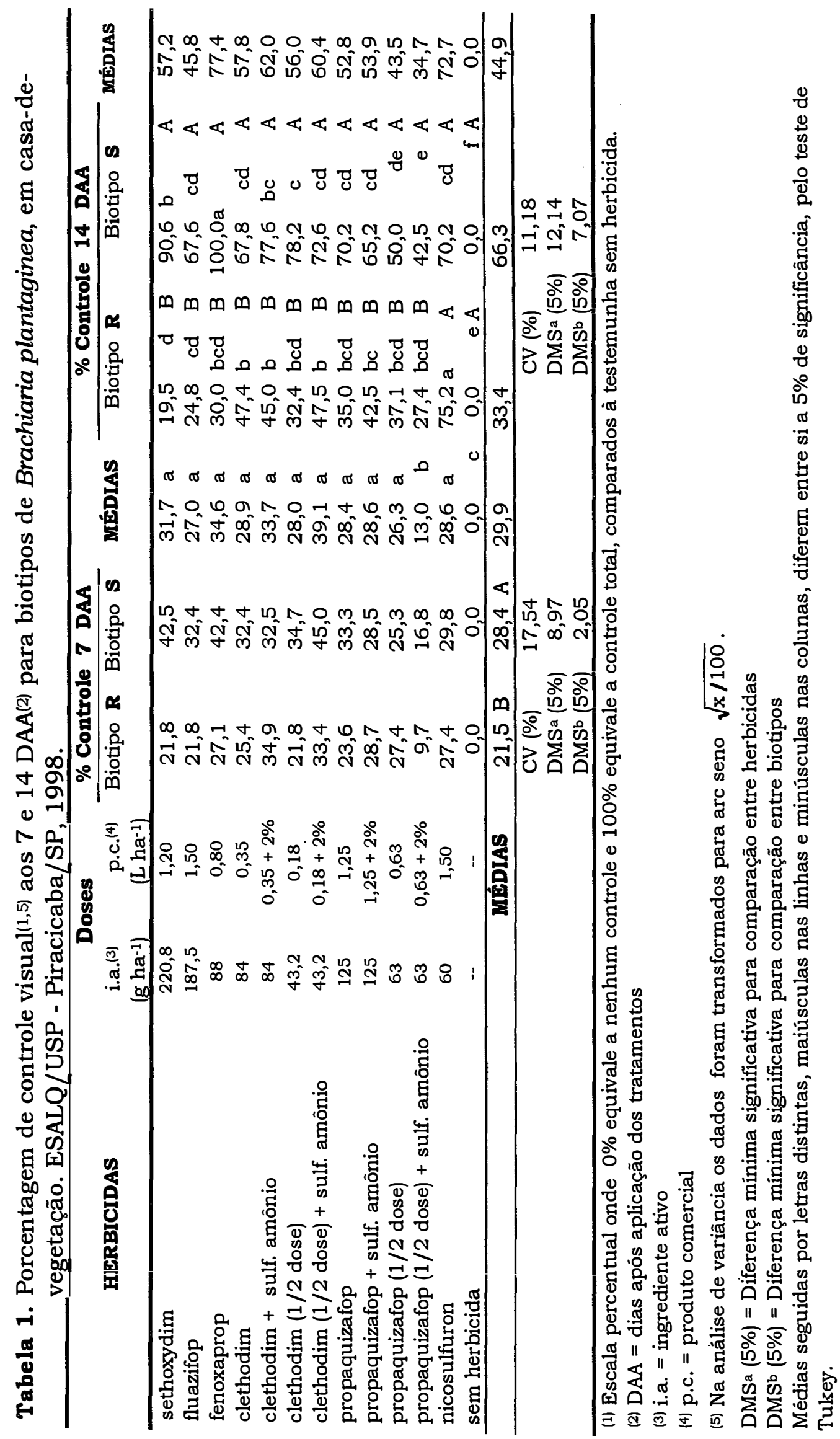


A produção de fitomassa foi mais reduzida no biotipo $R$, com o nicosulfuron (Tabela 2). No biotipo $\mathrm{S}$ observou-se a mesma tendência revelada nas avaliaçōes de controle; as menores produçōes de fitomassa foram obtidas com os herbicidas fenoxaprop e sethoxydim.

Os herbicidas inibidores da ACCase quando em mistura com sulfato de amônio não apresentaram melhora na eficiência de controle, porém, estes resultados foram menores do que o esperado, tanto para a dose de campo utilizada no experimento como para dose abaixo da recomendada.

A adição de sulfato de amônio não influenciou a eficácia de controle do biotipo $\mathrm{R}$, em nenhuma das variáveis avaliadas. nos tratamentos Observou-se um acréscimo na eficácia do herbicida clethodim em adição ao sulfato de amônio sobre o biotipo $\mathrm{S}$ somente quando aplicado em dose abaixo da recomendada.

Tabela 2. Fitomassa (g) recém colhida e seca, aos $15 \mathrm{DAA}^{(1)}$ para biotipos de Brachiaria plantaginea, em casa-de-vegetação. ESALQ/USP Piracicaba/SP, 1998.

\begin{tabular}{|c|c|c|c|c|c|c|c|c|}
\hline \multirow[b]{2}{*}{ HERBICIDAS } & \multicolumn{2}{|c|}{ Doses } & \multicolumn{5}{|c|}{ Fitomassa Recém Colhida } & \multirow[b]{2}{*}{ MÉDIAS } \\
\hline & $\begin{array}{c}\text { i.a.(2) } \\
\left(\mathrm{g} \mathrm{ha} \mathrm{a}^{-1}\right)\end{array}$ & $\begin{array}{c}\text { p.c. (3) } \\
\left(\mathrm{L} \mathrm{ha} \mathrm{a}^{-1}\right)\end{array}$ & Biotipo & $\mathbf{R}$ & Biot & tipo $\mathbf{s}$ & & \\
\hline sethoxydim & 220,8 & 1,20 & $26,3 a$ & A & 7,2 & $\mathrm{de}$ & $\bar{B}$ & 16,7 \\
\hline fluazifop & 187,5 & 1,50 & $28,9 a$ & A & 11,9 & bcde & $\mathrm{B}$ & 20,4 \\
\hline fenoxaprop & 88 & 0,80 & $24,4 a$ & A & 4,0 & e & $\mathrm{B}$ & 14,2 \\
\hline clethodim & 84 & 0,35 & $22,0 \mathrm{a}$ & A & 15,8 & bc & B & 8,9 \\
\hline clethodim + sulf. amônio & 84 & $0,35+2 \%$ & $23,6 \mathrm{a}$ & A & 8,3 & cde & B & 16,0 \\
\hline clethodim (1/2 dose) & 43,2 & 0,18 & $23,5 \mathrm{a}$ & A & 10,0 & cde & B & 16,8 \\
\hline clethodim (1/2 dose) + sulf. amônio & 43,2 & $0,18+2 \%$ & 25,7 a & A & 12,5 & bed & B & 19,1 \\
\hline propaquizafop & 125 & 1,25 & $28,1 \mathrm{a}$ & A & 16,0 & bc & B & 22,0 \\
\hline propaquizafop + sulf. amônio & 125 & $1,25+2 \%$ & 27,3 a & A & 18,6 & b & $\mathrm{B}$ & 22,9 \\
\hline propaquizafop ( $1 / 2$ dose) & 63 & 0,63 & 27,4 a & A & 19,0 & b & B & 23,2 \\
\hline propaquizafop ( $1 / 2$ dose) + sulf. amônio & 63 & $0,63+2 \%$ & $24,8 \mathrm{a}$ & A & 18,9 & $\mathrm{~b}$ & B & 21,8 \\
\hline nicosulfuron & 60 & 1,50 & $12,3 \quad b$ & A & 14,5 & $\mathrm{~b}$ & B & 13,4 \\
\hline \multirow[t]{5}{*}{ Testemunha sem herbicida } & -- & -- & 29,6 a & A & $27,5 \mathrm{a}$ & & B & 28,6 \\
\hline & & MÉDIAS & 24,9 & & 14,2 & & & 19,5 \\
\hline & & & \multicolumn{2}{|c|}{ CV $(\%)$} & &, 47 & & \\
\hline & & & \multicolumn{3}{|c|}{ DMSa $(5 \%)$} & 3,26 & & \\
\hline & & & \multicolumn{3}{|c|}{$\operatorname{DMSb}^{\mathrm{b}}(5 \%)$} & 4,81 & & \\
\hline
\end{tabular}

(1) $\mathrm{DAA}=$ dias após aplicação dos tratamentos

(2) i.a. $=$ ingrediente ativo

(3) p.c. $=$ produto comercial

$\operatorname{DMS}^{a}(\mathbf{5 \%})=$ Diferença minima significativa para comparação entre herbicidas

$\operatorname{DMS}^{\mathrm{b}}(5 \%)=$ Diferença minima significativa para comparação entre biotipos

Médias seguidas por letras distintas, maiúsculas nas linhas e minúsculas nas colunas, diferem entre si a 5\% de significância, pelo teste de Tukey. 
Os herbicidas inibidores da ACCase utilizados nos tratamentos, quando aplicados sozinhos ou em mistura com sulfato de amônio, não foram eficientes, como se esperava, no controle do biotipo resistente, porém controlou satisfatoriamente o biotipo suscetivel. Rodrigues \& Almeida (1998) confirmam o bom controle exercido pelos herbicidas selecionados sobre a planta daninha B. plantaginea.

\subsection{Avaliação de herbicidas alternativos no controle de população resistentes de Brachiara plantaginea em condiçōes de campo}

Os tratamentos com os herbicidas clethodim, nicosulfuron e a mistura rifluralin+nicosulfuron controlaram satisfatioriamente a planta daninha e o tratamento trifluralin+nicosulfuron apresentou os melhores resultados de controle em todas a avaliaçōes efetuadas (Tabela 3).

De modo geral, os herbicidas inibidores da ACCase falharam no controle do biotipo resistente, no campo e em casa de vegetação, embora tenham controlado satisfatoriamente o biotipo suscetivel. Tanto em casa-devegetação quanto no campo, o herbicida clethodim foi, entre os inibidores da ACCase testados, o que apresentou melhores resultados de controle sobre biotipo resistente. Estes resultados estão coerentes com os resultados de taxa de resisitência encontrados para diferentes herbicidas na Tabela 9 (Capitulo 3), verificando-se que, embora também com pouca eficácia no controle dos biotipos resistentes de $B$. plantaginea, o herbicida clethodim foi o que apresentou a menor taxa de resistência entre os inibidores da ACCase avaliados.

O herbicida alternativo nicosulfuron utilizado isoladamente, repetiu em campo os resultados encontrados sobre o controle dos biotipos de B. plantaginea em casa-de-vegetação. Embora estatisticamente iguais, a mistüra trifluralin+nicosulfuron, que também se apresenta como üma alternativa no controle de $B$. plantaginea resistente, apresentou os melhores resultados de controle no campo, em todas as avaliaçōes efetuadas. Estes 


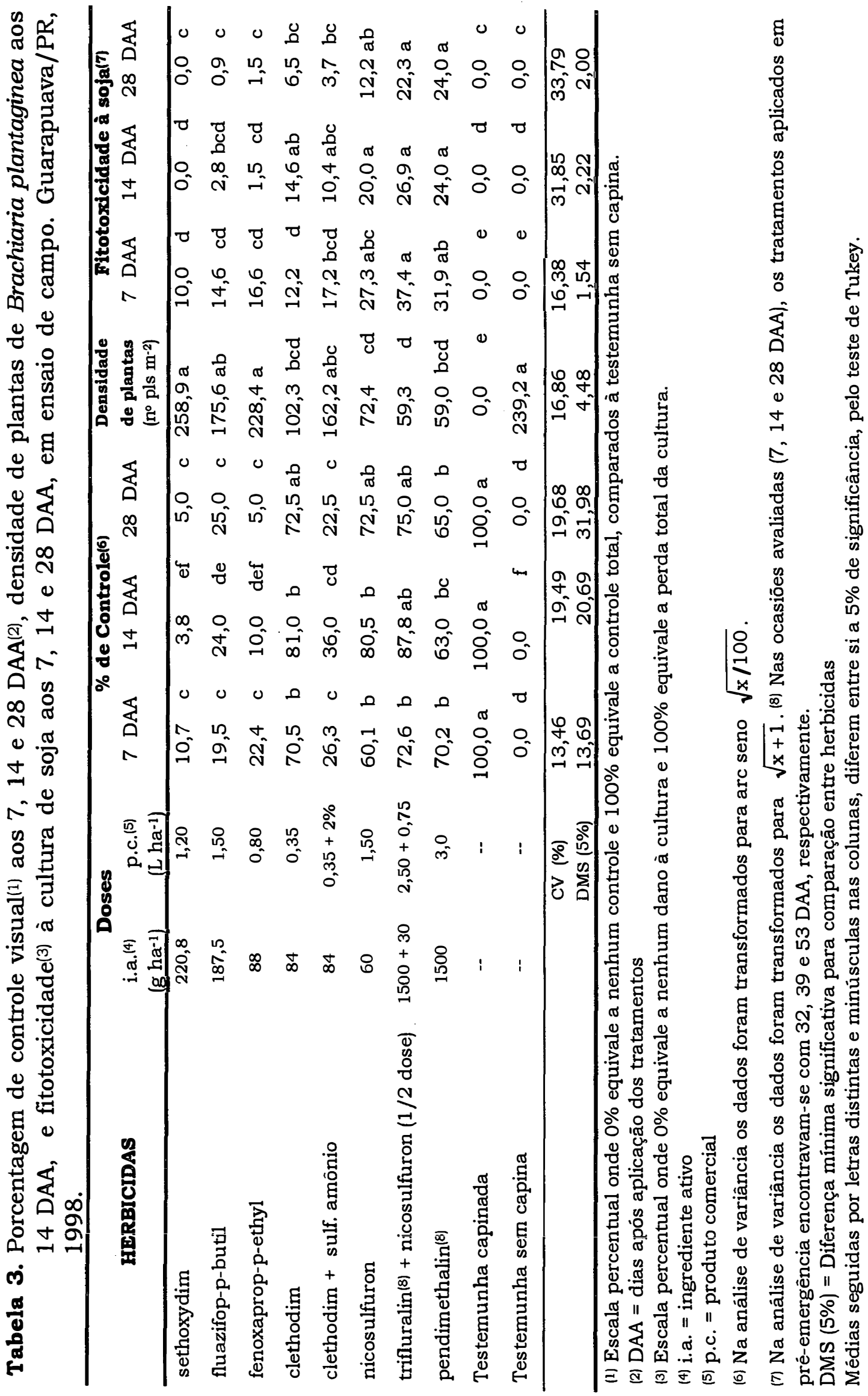


resultados evidenciam assim, a importância de se evitar o uso continuo, nas mesmas áreas, dos mesmos herbicidas ou de herbicidas com o mesmo mecanismo de ação. Christoffoleti et al. (1994) afirmam que a rotação de culturas pode permitir o uso de diferentes herbicidas, podendo desta forma colaborar para reduzir a pressão de seleção sobre o agroecossistema.

Dentre os resultados apresentados na Tabela 3, verifica-se também uma relação direta entre densidade de plantas de $B$. plantaginea encontradas aos 14 DAA e os niveis de controle obtidos. As menores

densidades de plantas foram encontradas entre os tratamentos que apresentaram melhores niveis de controle (nicosulfuron, trifluralin+nicosulfuron e pendimethalin).

Quanto à fitotoxicidade, os herbicidas inibidores da ACCase não afetaram a soja. Entretanto, os tratamentos com os herbicidas nicosulfuron, trifluralin+nicosulfuron e pendimethalin, afetaram fracamente a cultura, sendo que a soja tratada com nicosulfuron apresentou uma sensivel recuperação, resultando em fitotoxicidade minima deste herbicida na avaliação, aos 28 DAA.

O Herbicide Resistance Action Committee (HRAC) recomenda, dentre as estratégias de prevenção da resistência o uso da rotação de culturas que permite a alternância de herbicidas, e de misturas com diferentes mecanismos de ação que apresentem eficácia similar no controle da planta daninha alvo.

O herbicida nicosulfuron, embora não exista registro do seu uso em cultura de soja, foi incluido entre os tratamentos como uma possibilidade de controle alternativo à $B$. plataginea resistente, uma vez que foi utilizada no experimento a variedade de soja COODETEC-201, reconhecidamente tolerante a este herbicida. Desta forma, a utilização do herbicida nicosulfuron poderia justificar-se como produto alternativo em áreas com B. plantaginea resistente, não só na rotação de cultura com o milho como também na cultura da soja, desde que restrita ao uso da variedade citada.

Esta questão merece mais estudos, principalmente considerandose a ausência de registro do uso deste herbicida na cultura e também a falta de 
informaçōes com relaçāo a produtividade da soja, tratada nestas condiçōes. O experimento de campo realizado para este trabalho nāo permitiu que a colheita da soja fosse realizada por causa da intensa infestaçāo de $B$. plantaginea na ocasiāo da colheita.

Segundo Gressel \& Segel (1990) o uso de herbicidas alternativos, com diferentes mecanismos de açāo, pode tornar-se uma estratégia de sucesso no controle de plantas daninhas resistentes.

A utilizaçāo de herbicidas alternativos justifica-se à medida que se ampliam o espectro de controle necessário para a cultura da soja e as possibilidades de utilizaçāo de outras culturas em rotaçāo. Novos herbicidas e estratégias de controle devem ser incluídos em programas de manejo, nāo só através de misturas, mas também em rotaçāo de herbicidas.

Porém, no caso especial da cultura da soja em plantio direto, a restriçāo ao uso de herbicidas alternativos para o controle de plantas daninhas de folhas estreitas é grande, em funçāo da falta de opçōes de graminicidas pósemergentes seletivos à cultura e da necessidade de análises criteriosas quanto ao uso de herbicidas pré-emergentes.

O uso de herbicidas pré emergentes no sistema de plantio direto tem sido alvo de questionamentos por vários autores (Banks \& Robinson, 1982; Rodrigues, 1993) e de técnicos ligados à extensāo, a cooperativas, ao ensino e aos agricultores em geral. Alguns defendem a hipótese de que, no plantio direto pode-se reduzir ou até mesmo eliminar o uso de herbicidas de pré-emergência com o efeito físico e/ou alelopático das coberturas mortas. Por outro lado, há os que argumentam sobre a necessidade de se aumentar a dose de herbicidas pré-emergentes pois a grande parte do produto que fica retida na palhada, ou ainda porque sofre adsorçāo pela elevada quantidade de matéria orgânica presente nos solos deste sistema de cultivo, impedindo assim a disponibilidade do produto nas plantas. Estas perdas, segundo alguns autores, poderiam chegar até $50 \%$, dependendo das característica físico-químicas do herbicida, da quantidade de palha e da quantidade de chuva após aplicaçāo (Peixoto et al., 1997). 
O uso de herbicidas alternativos pode converter-se em uma ajuda ou alternativa às práticas normalmente recomendadas no controle de plantas daninhas resistentes a herbicidas, tais como a rotaçāo de culturas (nem sempre economicamente rentável), rotaçāo de herbicidas (nem sempre possível) e rotação de práticas culturais (nem sempre admitidas pelo agricultor).

Segundo o Comitê Brasileiro de Resistência de Plantas aos Herbicidas (CBRPH), é recomendável para a prevenção e manejo da resistência o manejo integrado de plantas daninhas, mantendo o ambiente desfavorável para estas plantas com a utilizaçāo isolada ou combinada dos métodos biológicos, culturais, mecânicos, químicos e físicos de controle. Também é necessário, um monitoramento constante e efetivo das áreas agrícolas, visando o desenvolvimento de métodos econômicos, eficientes e capazes de preservar o ambiente, e controlar as plantas daninhas.

\section{CONCLUSŌes}

Nas condições em que os experimentos foram realizados, os resultados obtidos permitem extrair as seguintes conclusōes:

- A população de Brachiaria plantaginea do experimento de campo em Guarapuava/PR é resistente a herbicidas inibidores da ACCase;

- No bioensaio em casa-de-vegetaçāo foi possivel comprovar diferenças significativas entre os biotipos resistente e suscetivel de Brachiaria plantaginea;

- No bioensaio em casa-de-vegetaçāo e no experimento de campo o herbicida nicosulfuron apresentou equivalência no controle do biotipo resistente;

- No campo, a mistura trifluralin+nicosulfuron apresentou o melhor controle observado;

- O herbicida nicosulfuron e a mistura rifluralin+nicosulfuron podem representar uma alternativa de controle quimico de populações resistentes à Brachiaria plantaginea, desde que utilizados com a soja da variedade COODETEC-201. 


\section{REFERÊNCLAS BIBLIOGRÁFICAS}

ALCÂNTARA, E.N. DE; CARVALHO, D.A. de Controle de plantas daninhas. Informe agropecuário, v.8, n.90, p.30-33, 1982.

BANKS , P.A.; ROBINSON, E.L. The influence off straw mulch on the soil reception and persisitence of metribuzin. Weed Science. v.30, p. 164-168, 1982

BARTLETT, M.S. Properties of sufficiency and statistical tests. Proc. Royal Soc., v.160, p. 268-282, 1937.

BLANCO, H.G. Catálogo das espécies de mato infestantes de áreas cultivadas no Brasil; gramineas de ciclo anual. O Biológico, São Paulo, v.41, n.1, p.6-14, 1975.

BROWN, H.M.; COTTERMAN, J.C. Recent advances in sulfonylurea herbicides. In: STETTER, J. ed. Herbicides Inhibiting Branched-Chain Acid Biosynthesis Springer-Verlag, New York. 1994.

CARVALHO, D.A. de Contribuiçao ao conhecimento da competição especifica de malerbas na cultura do feijoeiro (Phaseolus vulgaris L.). Rio Claro, UNESP, 1980. 65p (Dissertação de MS) UNESP-Rio Claro

CHRISTOFFOLETI, P.J.; CORTEZ, M.G. e VICTORIA FILHO, R. Resistance of alexanderweed (Brachiaria plantaginea) to ACCase inhibitor herbicides in soybean from Paraná State - Brazil. In: MEETING OF THE WEED SCIENCE SOCIETY OF AMERICA, CHICAGO, 1998. Abstracts. Chicago: WSSA, 1998. p. 65. 
CUSSANS, G.W. Which weed management strategies are appropriate? Proc. 2nd Int. Weed Control Congress, Copenhagen, p.1159-1166. 1996.

FREITAS, R.R. de; CARVALHO, A. de; ALVARENGA, A. A.de Quebra de dormência e germinaçāo de sementes de capim-marmelada (Brachiaria plantaginea). Revista Brasileira de Fisiologia Vegetal. v.2, p.31-35. 1990.

GARCÍA TORRES, L.; FERNÁNDEZ-QUINTANILLA, C. Fundamentos sobre malas hierbas y herbicidas. Mundi-Prensa. Madrid. 1991. 348p.

GRESSEL, J.; SEGEL, L.A. Herbicide rotations and mixtures: effective strategies to delay resistance. In: GREEN, M.B.; LeBARON, H.L.; MOBERG, W.R. Managing Resistance to Agrochemicals: from Fundamental Research to Practical Strategies. American Chemical Society. Washington, 1990. p.430-458.

JUTSUM, A. R.; GRAHAM, J. C. Managing weed resistance: the role of the agrochemical industry. Proc. Brighton Crop Prot. Con. Weeds, p. 557566. 1995.

KISSMANN, K.G. Plantas infestantes e nocivas. 1ed. São Paulo, SP: BASF Brasileira S.A., 1991. 603p.

LILLIEFORS, H.W. On the Kolmoganov - Smirnov test for normality with mean and variance unknown. Journal American Statistical, v.62, p.399-402, 1967.

LORENZI, H. Plantas daninhas do Brasil: terrestres, aquáticas, parasitas, tóxicas e medicinais. 2ed. Nova Odessa, SP: Editora Plantarum, 1991. 440 . 
MARLES, M.A.S.; DEVINE, M.D.; HALL, J.C. Herbicide resistance in Setaria viridis conferred by a less sensitive form of acetyl coenzyme A carbozylase. Pesticide Biochemistry and Physiology, v. 46, p.7-14, 1993.

MORRISON, I.N.; BOURGEOIS, L. Approaches to managing ACCase inhibitor resistance in wild oat on the Canadian prairies. Proceedings of the Brighton Crop Protection Conference-Weeds, Brighton, England, p. 567576. 1995

MOSS, S.R. Techniques for determining herbicide resistance.. Proceedings of the Brighton Crop Protection Conference-Weeds, Brighton, England, n. 38, p.547-556. 1985.

NORDMEYER, H.; HÄUSLER, A.; NIEMANN, P. Weed mapping as a tool for patchy weed control. Proc. 2nd Int. Weed Control Com. Copenhagen, p.119-124. 1996.

PEIXOTO, R.T.G.; AHRENS, D.C.; SAMAHA, M.J. Plantio direto: o caminho para uma agricultura sustentável. Ponta Grossa, PR: IAPAR, PRP?PG, 1997. 275p.

RODRIGUES, B.N. e ALMEIDA, F.S. Guia de herbicidas. 4. ed. Londrina: IAPAR, 1998, 648p.

RODRIGUES, B.N. Influência da cobertura morta no comportamento dos herbicidas imazaquin e clomazone. Planta Daninha. v.11, n.1/2, p. 21-28, 1993.

RUBIM, B. Herbicide resistant weeds. The inevitable phenomenon: mechanisms, distribution and significance. Zeitschrift fur Pflanzenkrankheiten und Pflanzenshutz, v.15, p.17-32, 1996. 
RUBIM, B. Herbicide resistance in weeds and crops, progress and prospects. In: CASELEY, J.C.; CUSSANS, G.W.; ATKIN, R.K.. Herbicide Resistance in Weeds and Crops. Butterworth-Heinemann Ed. Oxford, 1991. pp. 387414.

SHANER, D.L. Studies on the mechanism and genetics of resistance: their contribution to herbicide resistance management. Proc. Brighton Crop Prot. Conf.-Weeds, p.537-545. 1995.

VOOL, E.; GAZZIERO, D.L.P.; QUINA, E.; KRYZANOWSKI, F.C. Avaliação fisiológica de sementes de Brachiaria plantaginea com procedimentos da superação de dormência. Revista Brasileira de Sementes. v.18. p.186192. 1996.

WHYTE, R.O.; MOIR, T.R.G.; COOPER, J.P. Las gramineas en la agricultura. Roma, FAO, 1975. 464p. 


\section{CAPÍtulo vI}

\section{CONCLUSŌES GERAIS}

Do estudo da resistência de biotipos de Brachiaria plantaginea a herbicidas inibidores da ACCase, obteve-se as seguintes conclusões gerais:

a) Com relação a identificação de populações resistentes e a ocorrência de resistência cruzada em biotipos de $B$. plantaginea:

- As populações de $B$. plantaginea estudadas apresentaram niveis variados de sensibilidade aos herbicidas APP e CHD testados, sendo que a população suscetivel foi eficazmente controlada por estes produtos;

- Os biotipos resistentes estudados apresentaram resistência cruzada a diferentes herbicidas pertencentes aos grupos quimicos APP e CHD;

- De modo geral, o biotipo A apresentou maior resistência em relação ao outro biotipo testado.

b) Com relação ao mecanismo de resistência em biotipos de $B$. plantaginea resistente a herbicidas do grupo químico CHD:

- As diferenças na capacidade de absorçāo do sethoxydim e do tepraloxydim encontradas nos biotipos resistente e suscetivel de $B$. plantaginea não foram suficientes para justificar a ocorrência da resistência a estes herbicidas; 
- O processo de translocação dos herbicidas pelas diferentes parte da planta parece não contribuir de maneira significativa na resistência aos herbicidas CHD, no biotipo estudado;

- Considerando a inibição da ACCase como o mecanismo de ação dos herbicidas CHD, o estudo da sensibilidade da ACCase ao sethoxydim mostrou diferenças significativas entre os biotipos resistente e suscetivel estudados.

c) Com relação a alternativas de controle quimico para $B$. plantaginea existente em cultura de soja, no plantio direto:

- A população de Brachiaria plantaginea do experimento de campo em Guarapuava/PR é resistente a herbicidas inibidores da ACCase;

- No bioensaio em casa-de-vegetação foi possivel comprovar diferenças significativas entre os biotipos resistente e suscetivel de Brachiaria plantaginea;

- No bioensaio em casa-de-vegetação e no experimento de campo o herbicida nicosulfuron apresentou equivalência no controle do biotipo resistente;

- No campo, a mistura trifluralin+nicosulfuron apresentou o melhor controle observado;

- O herbicida nicosulfuron e a mistura trifluralin+nicosulfuron podem representar uma alternativa de controle químico de populaçōes resistentes à Brachiaria plantaginea, desde que utilizados com a soja da variedade COODETEC-201. 


\section{CAPÍTULO VII}

\section{REFERÊNCLAS BIBLIOGRÁFICAS GERAIS}

AHRENS, W.H. (Ed.) Herbicide handbook. 7. ed. Champaign, WSSA, 1994. $352 \mathrm{p}$.

ALBAN, C.; BALDET, P.; DOUCE, R. Localization and characterization of two structurally different forms of acetyl-CoA carboxylase in young pea leaves, of which one is sensitive to aryloxyphenoxypropionate herbicides. Biochemical Journal n.300, p.557-565, 1994.

ALCÂNTARA, E.N. DE; CARVALHO, D.A. de Controle de plantas daninhas. Informe agropecuário, v.8, n.90, p.30-33, 1982.

BANKS , P.A.; ROBINSON, E.L. The influence off straw mulch on the soil reception and persisitence of metribuzin. Weed Science. v.30, p. 164-168, 1982

BARTLETT, M.S. Properties of sufficiency and statistical tests. Proc. Royal Soc., v.160, p. 268-282, 1937.

BETTS, K.J.; EHLKE, N.J.; WYSE, D.L.; GRONWALD, J.W.; SOMMERS, D.A. Mechanism of inheritance of dicloflop resistance in Italian ryegrass (Lolium multiflorum). Weed Science, n.40, p.184-189, 1992. 
BLANCO, H.G. Catálogo das espécies de mato infestantes de áreas cultivadas no Brasil; gramineas de ciclo anual. O Biológico, São Paulo, v.41, n.1, p.6-14, 1975.

BOLDT, L.D.; BARRETT, M. Effects of Diclofop and Haloxyfop on Lipid Synthesis in Corn (Zea mays) and Bean (Phaseolus vulgaris). Weed Science, v.39, p.143-148, 1991.

BORGEOIS, L.; KENKEL, N.C.; MORRISON, I.N. Characterization of crossresistance patterns in acetyl-CoA carboxylase inhibitor resistance wild oat (Avena fatua). Weed Science, v.45, p.750-755. 1997

BREZEANU, A.G.; DAVIS, D.G.; SHIMABUKURO, R.H. Ultraestructural effects and translocation of methyl 2-(4-(2,4-dichloro-phenoxy)phenoxy) propanoate in wheat (Triticum aestivum) and wild oat (Avena fatua). Canadian Journal of Botanic, v.54, p.2038-48, 1976.

BROMILOW, R.H.; CHAMBERLAIN, K. Pathways and mechanisms of transport of herbicide in plants. In: KIRKWOOD, R.C., ed Targest sites for herbicides action. Plenum Press, Nueva York, p.245-284. 1991.

BROWN, H.M.; COTTERMAN, J.C. Recent advances in sulfonylurea herbicides. In: STETTER, J. ed. Herbicides Inhibiting Branched-Chain Acid Biosynthesis Springer-Verlag, New York. 1994.

BURNET, M.W.; LOVEYS, B.R.; HOLTUM, J.A.M.; POWLES, S.B. Increased detoxification is a mechanism of simazine resistance in Lolium rigidum. Pesticide Biochemistry and Physiology, n. 4h, p. 207-218, 109.3. 
BURNET, M.W.M; LOVEYS, B.R.; HOLTUM, J.A.M.; POWLES, S.B. A mechanism of chlorotoluron resistance in Lolium rigidum. Planta, n.190, p.182-189, 1993.

BURTON, J.D.; GRONWALD, J.W.; KEITH, R.A.; SOMERS, D.A.; GENGENBACH, B.G.; WYSE, D.L. Kinetics of Inhibition of AcetylCoenzyme A Carboxylase by Sethoxydim and Haloxyfop. Pesticide Biochemistry and Physiology, v. 9, p.100-109, 1991.

BURTON, J.D.; GRONWALD, J.W.; SOMERS, D.A.; BURLE, G.G.; WYSE, D.L. Inhibition of corn acetyl CoA carboxylase by cylclohexanodione and aryloxypropionate herbicides. Pesticide Biochemistry and Physiology, n. 34, p. 76-85, 1989.

BURTON, J.D.; GRONWALD, J.W.; SOMERS, D.A.; CONNELY, J.A.; GENGENBACH, B.G.; WYSE, D.L. Inhibition of Plant Acetyl-oenzyme A Carboxylase by the Herbicidez Sethoxydim and Haloxyfop. Biochemical Biophys. Res. Commum., v.148, p.1039-1044, 1987.

CARVALHO, D.A. de Contribuiçao ao conhecimento da competição específica de malerbas na cultura do feijoeiro (Phaseolus vulgaris L.). Rio Claro, UNESP, 1980. 65p (Dissertação de MS) UNESP-Rio Claro

CHRISTOFFOLETI, P.J.; CORTEZ, M.G. e VICTORIA FILHO, R. Resistance of alexanderweed (Brachiaria plantaginea) to ACCase inhibitor herbicides in soybean from Paraná State - Brazil. In: MEETING OF THE WEED SCIENCE SOCIETY OF AMERICA, CHICAGO, 1998. Abstracts. Chicago: WSSA, 1998. p. 65.

CHRISTOFFOLETI, P.J.; VICTORIA FILHO, R.; SILVA, C.B. Resistência de plantas daninhas aos herbicidas. Planta Daninha, v.12, n.1, p.1320., 1994 . 
COBLE, H.D. Weed management tools and their impact on the agro-ecosystem. Proc. 2nd Int. Weed Control Congress, Copenhagen, p. 1143-1146. 1996.

COLE, D.J. Detoxification and activation of agrochemicals in plants. Pesticide Science, v.42, p.209-222, 1994.

CORBETT, J.R.; WRIGHT, D.; BAILLIE, A.C. The biochemical mode of action of pesticides. Academic Press, London. 1984.

CORNES, D.W.; MILLS, C.E.; RYAN, P.J. Development and management of resistance to aryloxyphenoxypropionates in Alopecurus mysuroides in the UK. Proc. International Symp. Weed and Crop Resistance to Herbicides, Cordoba, Spain, p.229-230, 1995.

CORTEZ, M.G. CHRISTOFFOLETI, P.J.; VICTORIA FILHO, R.; DE PRADO, R. Differential tolerance to graminicides in Brachiaria plantaginea biotypes found in Brazil. In: $11^{\text {th }}$ SYMPOSIUM OF EUROPEAN WEED RESEARCH SOCIETY, 1999. Procedings. Basel: Switzerland, 1999. p.164

COUPLAND, D. The role of compartmentation of herbicides and their metabolites in resistance mechanisms. In: CASELEY, J.; C. CUSSANS, G.W.; ATKIN, R.K. eds Herbicides resistance in weeds and crops. Butterworth-Heinemann Ltd., Oxford. p-263-278. 1991.

CUSSANS, G.W. Which weed management strategies are appropriate? Proc. $2^{\text {nd }}$ Int. Weed Control Congress, Copenhagen, p.1159-1166. 1996.

DE PRADO, R.; DOMINGUEZ, C.; TENA, M. Characterizacion of riazineresistant biotypes of common lamhsquaters (Chenonndium album), Hairy Fleabane (Conyza bonariensis), and Yellow Foxtail (Setaria glauca) found in Spain. Weed Science, n.37, p.1-4, 1996. 
DE PRADO, R.; DOMINGUEZ, C.; TENA, M. Triazine resistance in biotypes of Solanum nigrum and four Amaranthus species found in Spain. Weed Research. n.33, p.17-24, 1993a.

DE PRADO, R.; LOPEZ, N. Resistencia a herbicidas: Detección en campo y laboratorio. In: I CURSO SOBRE EL USO DE HERBICIDAS EN LA AGRICULTURA MODERNA. Cordoba/Espanha, 1999. Resumos. ETSIAM/UCO, 1999. p. 52.

DE PRADO, R.; LOPEZ-MARTINEZ, N.; GIMENEZ-ESPINOSA, R. Herbicide resistant weeds in Europe: agricultural, physiological and biochemical aspects. In: DE PRADO, R., JORRIN, J.,Y GARCIA-TORRES, L., (eds). Weed and Crop Resistance to Herbicides. Kluwer Academic Publisher, p. 17-27. 1997.

DE PRADO, R.; MENÉNDEZ, J.; TENA, M. Response to substituted ureas, triazines and chloroacetanilides in a biotype of Alopecurus myossuroides resistant to chlorotoluron. In: BRIGHTON CROP PROTECTION CONFERENCE - WEEDS. p. 1065-1070, 1991.

DE PRADO, R.; MENENDEZ, J.L. Cross-resistance and herbicide metabolism in Alopecurus myosuroides Huds. In: Regulation of Enzymatic System Detorifying Xenobiotics in Plants (HATZIOS, K. K., ed.). Kluwer Academic Publisher, p. 351-366. 1997.

DE PRADO, R.; ROMERA, E.; JORRIN, J. Effects of chloroacetamides and photosynthesis-inhibiting herbicides on growth and photosynthesis in sunflower (Helianthus annus L.) and Amaranthus hybridus L. Weed Research. n .33, p. 369-374, 1993b. 
DEVINE, M.; HALL, J.C.; ROMANO, M.L.; MARLES, M.A.S.; THOMPSON, L.W.; SHIMABULURO, R.H. Diclofop and fenoxaprop resistance in wild oat is associated with an altered effect on the plasma membrane electrogenic potential. Pesticide Biochemistry and Physiology, v.45, p.167-177, 1993b.

DEVINE, M.D. Mechanisms of resistance to acetyl coenzyme A carboxylase inhibitors: a review. Pesticide Science, v.51, p.259-264, 1997.

DEVINE, M.D. The biochemical basis of herbicide resistance in wild oat. In: Wild Oats in World Agriculture. In: 4TH INT. OAT CONF. (Barr, A. R., Medd, R.W., eds.). Adelaide, Australia, Proceedings. p. 41-44. 1992a.

DEVINE, M.D.; DUKE, S.O.; FEDTKE, C. Physiology of Herbicide Action. Prentice Hall, Englewood Cliffs, NJ. 1993a.

DEVINE, M.D.; McISAAC, S.A.; ROMANO, M.L.; HALL, J.C. Investigation of the Mechanism of Diclofop Resistance in Two Biotypes of Avena Fatua.. Pesticide Biochemistry and Physiology, v.42, p.88-96, $1992 \mathrm{~b}$.

DEVINE, M.D.; SHIMABUKURO, R.H. Acetyl coenzyme A carboxylase inhibiting herbicides. In: POWLES, S.B. ; HOLTUM, J. A.M. eds Herbicide Resistance in Plants: Biology and Biochemistry, p.141-169. CRC Press, London. 1994.

DITOMASO, J.M.; STOWE, A.E.; BROWN, P.H. Inhibition of Lipid Synthesis by Diclofop-Methyl is Age Dependent in Roots of Oat and Corn. Pesticide Biochemistry and Physiology, v.45, p.210-219, 1993.

DUKE, S.O. Modes of action of herbicides used in cotton. In: McWHORTER, C.G.; ABERNATHY, J.L, eds. Weeds of Cotton: Characterization and Control The Cotton Foundation, Memphis, TN, p. 403-437. 1992. 
DUKE, S.O.; KENYON, W. H. Polyciclic alkanoic acids. In: KEARNEY, P.C.; KAUFMAN, D.D. eds. Herbicides: Chemistry, Degradation, and Mode of Action Marcel Dekker, New York, p. 71-116. 1988.

EBEL, J.; HAHLBROCK, K. Enzymes of flavone and flavonol glycoside biosynthesis. Coordinated and selective induction in cell-suspension cultures of Petroselinum hortense. European Journal of Biochemistry, v. 75, p. 201-209, 1977.

EGLI, M.A.; GENGENBACH, B.; GRONWALD, J.W.; SOMERS, D.A.; WISE, D.L. Characterization of maize acetyl-Coenzime A carboxylase. Plant Physiology, n.101, p.499-506, 1993.

F.A.O. Production Yearbook. Vol. 51. 1997.

FREITAS, R.R. de; CARVAlHO, A. de; ALVARENGA, A. A.de Quebra de dormência e germinação de sementes de capim-marmelada (Brachiaria plantaginea). Revista Brasileira de Fisiologia Vegetal. v.2, p.31-35. 1990.

GARCÍA TORRES, L.; FERNÁNDEZ-QUINTANILLA, C. Fundamentos sobre malas hierbas $\mathrm{y}$ herbicidas. Mundi-Prensa. Madrid. 1991. 348p.

GAZZIERO, D.L.P; BRIGHENTI, A.M.; MACIEL, C.D.G.; CHRISTOFFOLETI, P.J.; ADEGAS, F.S. Resisitência der amendoim-bravo aos herbicidas inibidores da enzima ALS. Planta Daninha, v.16, p. 117-126, 1998.

GAZZIERO, D.L.P; CHRISTOFFOLETI, P.J.; MACIEL, C.D.M.; SCARAMUZA JÚNIOR., J.R. Resistência de biótipos de Brachiaria plantaginea aos herbicidas inibidores da ACCase aplicados em soja. In: CONGRESSO BRASILEIRO DA CIÊNCIA DAS PLANTAS DANINHAS. 21, Caxambu/MG, 1997. Resumos. Caxambu:SBCPD, 1997. p.88. 
GILLET, M. Las gramineas forrajeras: descripción, funcionamento, aplicaciones al cultivo de la hierba. Zaragoza, Acribia, 1984. 355p.

GIMENEZ-ESPINOSA, M.R.M. Mecanimos de tolerência de garbanzo a piridato e y a los herbicidas ariloxifenoxipropionatos. Interacción entre la tolerância a herbicidas y la resistência a Fusarium oxysponum. Cordoba, 1997. 251p. (Tese Doutorado) - Escuela Técnica de Inginieros Agrônomos y de Montes - Universidad de Cordoba/Espanha.

GRESSEL, J. Why get resistance ? It can be prevented or delayed. In: CASELEY, J.C.; CASELEY, G.W.; ATKIN, R.K. Herbicide Resistance in Weeds and Crops. Buterworth-Heinemann Ed. Osford, 1991. p.1-25.

GRESSEL, J.; SEGEL, L.A. Herbicide rotations and mixtures: effective strategies to delay resistance. In: GREEN, M.B.; LeBARON, H.L.; MOBERG, W.R. Managing Resistance to Agrochemicals: from Fundamental Research to Practical Strategies. American Chemical Society. Washington, 1990. p.430-458.

GRESSEL, J.L.; SEGEL, L.A. Interrelating factors controlling the rate of apperance of resistance: the outlook for the future. In: LeBARON, H. M.; GRESSEL, J.L., Herbicide Resistance in Plants John Wiley \& Sons, New York, p.325-347. 1982.

GRIGNON, C.; SENTENAC, H. pH and ionic conditions in the apoplast. Annual Review of Plant Physiology and Plant Molecular Biology, v.42, p. $103-128,1991$.

GRONWALD, J.,W.; EBERLEIN, C.V.; BETTS, K.J.; ROSCOW, K.M.; EHLKE, N.J.; WYSE, D.L. Diclofop resistance in a biotype of Italian rye-grass. Plant Physiology 89 (Abstract no. 685), 115. 1989. 
GRONWALD, J.W. Lipid biosynthesis inhibitors. Weed Science, v.39, p.435449, 1991.

GRONWALD, J.W. Herbicides inhibiting acetyl-CoA carboxylase. Biochemical Society Transactions, v. 22, n.3, p.616-621, 1994b.

GRONWALD, J.W. Resistance to photosystem II inhibiting herbicides. In: POWLES, S.B. ; HOLTUM, J. A.M. eds Herbicide Resistance in Plants: Biology and Biochemistry, p. 27-60. 1994a.

GRONWALD, J.W.; EBERLEIN, C.V.; BETTS, K.J.; BAERG, R.J.; EHLKE, N.J.; WYSE, D.L. . Mechanism of diclofop resistance in na Italian ryegrass (Lolium multiflonum Lam.) biotype. Pesticide Biochemistry and Physiology, n. 44, p.126-139, 1992.

GUNSOLUS, J.L. Herbicide resistant weeds. Extension Publication. Minessota Extension Service. 1993. 468p.

HALL, L.M.; TARDIFF, F.; POWLES, S.B. Mechanism of cross and multiple resistance in Alopecurus mysuroides and Lolium rigidum. Phytoprotecion, v. 73, p.17-23, 1994.

HARWOOD, J.L. Fatty acid metabolism. Annu. Rev. Plant Physiol. Plant Mol. Biol., v.39, p.101-138, 1988.

HATZIOS, K.K..; PENNER, D. Metabolism of herbicides in higher plants. Minneapolis: Burgess, 1990. 142p.

HÄUSLER, R.E.; HOLTUM, J.A.M.; POWLES, S.B. Cross-resistance to herbicides in annual ryegrass (Lolium rigidum). IV. Correlation between membrane effects and resistance to graminicides. Plant physiology, n.97, p.1035-1043, 1991 
HEAP, I.M. International survey of herbicide-resistant weeds. Orlando (FL): WSSA/HRAC, 1997. 33 p. (Annual Report)

HEAP, I.M. The ocurrence of herbicide-resistant weeds worlwide. Pesticide Science, v.51, p.235-243, 1997.

HEAP, I.M.; KNIGHT, R. Variation in Cross-Resistance among Populations of Annual Ryegrass (Lolium rigidum) Resistant to Diclofop-Methyl. Australian Journal of Agricultural Reseach. v.41, p.21-128, 1990.

HEAP, I.M.; KNIGHT, R.A population of ryegrass tolerant to the herbicide diclofop-methyl. Journal Austral. Ins. Agric. Sci., v.48, p.156-157, 1982.

HEAP, I.M.; MORRISON, I. N. Resistance to aryloxyphenoxypropionate and cyclohexanodione herbicides in Green Foxtail (Setaria viridis). Weed Science, v.44, p.25-30. 1996.

HEAP, I.M.; MORRISON, I.N. Resistance to aryloxyphenoxypropionate and cyclohexanodione herbicides (Group 1) herbicides in Green foxtail (Setaria viridis L. Beav.). WSSA Abstracts. Denver, Colorado. 55: p.164. 1982.

HEAP, I.M.; MURRAY, B.G.; LOEPPKY, H.A.; MORRISON, I.N. Resistance to aryloxyphenoxypropionate and cyclohexanodione herbicides in wild oat (Avena fatua). Weed Science, v.41, p.232-238, 1993.

HERBERT, D.; COLE, D.J.; PALLETT, K.E.; HARWOOD, J.L. Susceptibilities of different tests systems from mays (Zea mays), Poa annua and Festuca rubra to herbicides that inhibit the enzyme acetyl-coenzyme A carboxylase. Pesticide Biochemistry and Physiology, v. 55, p.129-139, 1996. 
HESS, F.D. Herbicide absorption and translocation and their relationship to plant tolerance and susceptibility. In: DUKE, S.O. ed. Weed Phsyiology, vol. II: Herbicide Physiology CRC Press, Boca Raton. p.192-214., 1985.

HOLT, J. Fimess and ecological adaptability of herbicide resistant biotypes. In: GREEN, M.B.; LeBARON, H.L.; MOBERG, W.K. Managing Resistance to Agrochemicls: from Fundamental Research to Practical Strategies. American Chemical Society. Washington, p.419-429. 1995.

HOLT, J.S.; LeBARON, H.M. Significance and distribution of herbicide resistance. Weed Technology, n.4, p.141-49, 1990.

HOLTUM, J. A.M. Herbicide resistant wild oats in Australia. In: Wild Oats in World Agriculture, Proc. 4th Int. Oat Conf. (Barr, A. R., Medd, R. W., eds.). Adelaide, Australia, p. 45-48. 1992.

HOLTUM, J.A.M.; HÄUSLER, R.E.; DEVINE, M.D.; POWLES, S.B. Recovery of transmembrane potentials in plants resistant to aryloxyphenoxypropanoate herbicides: A phenomenon awaiting explantion. Weed Science, n.42, p.293-301, 1994.

HOLTUM, J.A.M.; MATTHEWS, J.M.; HÄUSLER, R.E.; LILJEGREN, D.R.; POWLES, S.B. Cross-resistance to herbicides in annual ryegrass (Lolium rigidum).III. On the mechanism of resistance to diclofop-methyl. Plant Physiology, n.97, p.1026-1034, 1991.

HOPPE, H.H. Differential Effect of Diclofop-Mehtyl on Fatty Acid Biosynthesis in Leaves of Sensitive and Tolerant Plant Species. Pesticide Biochemistry and Physiology., v. 23, p. 297-308, 1985. 
HOPPE, H.H. Fatty acid biosynthesis - a target site of herbicide action. In: BÖGER, P.; SANDMANN, G., eds Target sites of herbicide action, CRC Press, Boca Ration. p.65-83, 1989.

HOSAKA, H.; TAKAGI, M. Biochemical effects of sethoxydim in excised root tips of corn (Zea mays). Weed Science, v.35, p.612-618, 1989.

ISHIHARA, K.; KOSAKA, H.; KUBOTA, M.; KAMIMURA, H.; TAKAKUSA, M.; YASUDA, Y. Effects of sethoxydim on the metabolism of excised root tips of corn. In: GREENHALGH, R. ; ROBERTS, T. (eds.) Pesticide Chemistry and Techonolgy, Blackwell Scientific, Palo Alto, CA. 1987, p.187-190.

JAGER, G. Herbicides. In: BÜCHEL, K. H. Chemistry of pesticides John Wiley \& Sons, New York, p.322-392. 1983.

JEFFCOAT, B.; HARRIES, W.N. Selectivity and mode of action of ethyl $( \pm)$-2Nbenzoyl-3, 4-dichloroanilino) propionate in the control of Avena species in wheat. Pesticide Science, v. 4, p.891, 1973.

JOSEPH, O.O.; HOBBS, S.L.A. \& JANA, S. Diclofop Resistance in Wild Oat (Avena fatua). Weed Science, v. 38, p. 475-479, 1990.

JUTSUM, A. R.; GRAHAM, J. C. Managing weed resistance: the role of the agrochemical industry. Proc. Brighton Crop Prot. Con. Weeds, p. 557566. 1995.

KAFIZ, B.; CAUSSANEL, J.P.; SCALLA, R.; GAILLARDON, P. Interaction Between Diclofop-methyl and 2,4-D in Wild Oat (Avena fatua L.) and Cultivated Oat (Avena sativa L.) and Fate of Diclofop-Methyl in Cultivated Oat. Weed Research, v. 29, p. 299-305, 1989. 
KISSMANN, K.G. Plantas infestantes e nocivas. 1ed. São Paulo, SP: BASF Brasileira S.A., 1991. 603p.

KOBEK, K.; FOCKE, M.; LICHTENTHALER, H. K. Fatty acid biosynthesis and acetyl-CoA carboxylase is a target of diclofop, fenoxaprop and other ariloxyphenoxy-propionic acid herbicides. Z. Naturforsch., v.43, p.47-54, 1987.

KOBEK, K.; FOCKE, M.; LICHTENTHALER, H. K.; RETZLAFF, G.; WÜRZER, B. Inhibition of fatty acid biosynthesis in isolated chloroplast by cycloxidim and other cyclohexane-1,3-diones. Physiology Plantarum, v.72, p.492498, 1988.

KONISHI, T.; SASAKI, Y. Compartmentalization of two forms of acetyl-CoA carboxylase in plants and the origin of their tolerance toward herbicides. Proc. Natl. Acad. Sci., USA, v.91, p.3598-3601, 1994.

LADLIE, J.S. Guide to herbicide injury symptoms in soybeans with "look-alike" symptoms. Hollamdale: Agri-Growth Research, 1991, 86 p.

LeBARON, H.M. Herbicide resitance in crops and weeds and its management. In: TROPICAL WEED SCIENCE CONFERENCE, 3, Kuala Lumpur/Malasia, 1992. Proceedings. p.23-24. 1992.

LeBARON, H.M.; GRESSEL, J. Herbicide resistance in plants. New York: John Wiley \& Sons. 1982. 441p.

LICHTENTHALER, H.K.; KOBEK, K. Inhibition by sethoxydim of pigment accumulation and fatty acid biosynthesis in chloroplast of Avena seedlings. Z. Naturforsch, v.42, p.1275-1279, 1987. 
LILLIEFORS, H.W. On the Kolmoganov - Smimov test for normality with mean and variance unknown. Journal American Statistical, v.62, p.399-402, 1967.

LORENZI, H. Plantas daninhas do Brasil: terrestres, aquáticas, parasitas, tóxicas e medicinais. 2ed. Nova Odessa, SP: Editora Plantarum, 1991. 440 .

MALLORY-SMITH, C.A.; THILL, D.C.; MORISHITA, D. Herbicide-resistant weeds and their management. Corvallis: Oregon State University. PNW Extension Publication, 1993. 437p.

MANEECHOTE, C.; HOLTUM, J.M.; PRESTON, C.; POWLWS, S.B. Resistant acetyl-CoA carboxylse is a mechanism of herbicide resisitance in a biotype of Avena sterilis spp ludoviciana. Plant Cell Physiology, v.35, p.27-35, 1994.

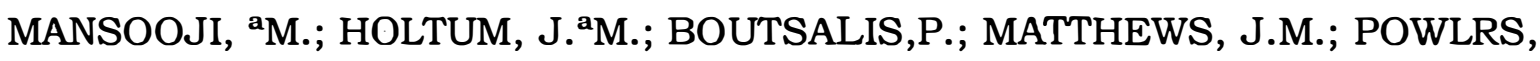
S.B. Resistance to aryloxyfhenoxypropionate herbicides in two wild oat species (Avena fatua and Avena sterilis). Weed Science, v.40, p.599-605, 1992.

MARLES, M.A.S.; DEVINE, M.D.; HALL, J.C. Herbicide resistance in Setaria viridis conferred by a less sensitive form of acetyl coenzyme A carbozylase. Pesticide Biochemistry and Physiology, v. 46, p.7-14, 1993.

MARSHALL G.; KIRKWOOD, R.C.; LEACH, G.E. Comparative studies on graminicide-resistant and susceptible biotypes of Eleusine indica. Weed Research, v. 34, n.3, p.177-185, 1994. 
MATHEWS, J.M.; HOLTUM, J.A.M.; LILJEGREN, D.R.; FURNESS, B.; POWLES, S.B. Cross-resistance to herbicides in annual ryegrass (Lolium rigidum). I. Properties of the target enzymes acetyl-coenzyme A carboxylase and acetatolactate synthase. Plant Physiology, v.94, p.1180-1186, 1990.

MATTHEWS, J.M. Management of herbicide resistant weed populations. In: POWLES, S.B.; HOLTUM, J.A.M., eds. Herbicide Resistance in plants: Biology and biochemistry p. 317-335, CRC PRESS, Boca Ration. 1994.

MAXWELL, B.D.; MORTIMER, M. Selection for herbicide resistance. In: Herbicide Resistance in Plants: Biology and Biochemistry (Powles, S. B., y Holtum, J. A. M., eds.). CRC Press, Boca Raton, p.1-25. 1994.

MENENDEZ, J.; DE PRADO, J.L.; DE PRADO, R. Diclofop metabolism in resistant biotypes of Lolium rigidum Gaudin. Proceedings of the International Symposium on Weed and Crop Resistance to Herbicide, Cordoba, Spain, 1996, p.97-98.

MENENDEZ J.; JORRIN, J.; TABERNER, A.; DE PRADO, R. Penetration, translocation and metabolization of diclofop-methyl in chlorotoluronresistant and susceptible biotypes of Alopecurus myosuroides. Proceedings of the Brighton Crop Protection Conference-Weeds, Brighton, England 1993, p.213-220.

MENENDEZ, J. Mecanismos de resistência a herbicidas en biotipos de Alopecurus myosuroides huds. Cordoba, 1997. 246p. Tese (Doutorado) Escuela Técnica de Ingenieros Agrónomos y de Montes - Universdiad de Cordoba/Espanha. 
MENENDEZ, J.; DE PRADO, R. Detoxification of chlorotoluron in a chlorotoluron - resistant biotype of Alopecurus myossuroides. Comparison between cell cultures and whole plants. Physiologia Plantarum. v.99, p.97-104, 1997.

MENENDEZ, J.; DE PRADO, R. Detoxification of chlorotoluron in a chlorotoluron - resistant biotype of Alopecurus myossuroides. Comparison between cell cultures and whole plants Physiologia Plantarum. v. 99, p.97-104, 1997.

MENENDEZ, J.; DE PRADO, R. Diclofop-methyl cross-resistance in a chlorotoluron resistant biotype of Alopecurus myossuroides. Pesticide Biochemistry and Physiology, v. 56, p. 123-133, 1996.

MENENDEZ, J.; DE PRADO, R. La resistencia de las malas hierbas a los herbicidas. Phytoma, 94, 43-50, 1998.

MENENDEZ, J.; JORRIN, J.; ROMERA, E.; DE PRADO, R. Resistance to chlorotoluron of a slender foxtail (Alopecurus myosuroides) biotype. Weed Science, v. 42, p. 340-353, 1994.

MONQUEIRO, P.A. Biologia, manejo e caracterizaçāo bioquímica e genética de biotipos de plantas daninhas resistentes aos herbicidas inibidores da acetolato sintase (ALS). ESALQ-Piracicaba, SP, 1999. 94p. (Dissertação Mestrado) - ESALQ - Universidade de Sāo Paulo

MORGAN, W.C. Alternatives to herbicides. Plant Protection Quality. v. 4, n.1, p. 33-37, 1989. 
MORRISON, I.N.; BOURGEOIS, L. Approaches to managing ACCase inhibitor resistance in wild oat on the Canadian prairies. Proceedings of the Brighton Crop Protection Conference-Weeds, Brighton, England, p. 567576. 1995

MOSS, S.R. Herbicide cross-resistance in slender foxtail (Alopecurus myosuroides). Weed Science, v. 38, p. 492-496, 1990,

MOSS, S.R. Techniques for determining herbicide resistance.. Proceedings of the Brighton Crop Protection Conference-Weeds, Brighton, England, n. 38, p.547-556. 1985.

MOSS, S.R.; CUSSANS, G.W. The development of herbicide-resistant populations of Alopecurus myosuroides (black-grass) in England. In: CASELEY, J.C.; CUSSANS, G.W.; ATKIN, R.K., eds, Herbicide resistance in weeds and crops, Butterworth-Heinemann, Oxford. p.45-55, 1991.

NEALE, M.C.; SUTTON, A. European view of horticultural crop protection. In: D. TYSON, ed Crop protection: Crisis for UK Horticulture? British Crop Protection Council, Farnham. p.79-88, 1993.

NIKOLAU, B. J.; Y HAWKE, J. C. Purification and characterization of maize leaf acetyl-coenzime A carboxylase. Arch. Biochem. Biophys., v.228, p.86-96, 1984.

NORDMEYER, H.; HÄUSLER, A.; NIEMANN, P. Weed mapping as a tool for patchy weed control. Proc. 2ad Int. Weed Control Com. Copenhagen, p.119-124. 1996.

O'SULLIVAN, P.A. Diclofop. In: DONALD, W.W. Systems of weed control in wheat in North America, WSSA, Champaign, p.321-345, 1990. 
OHLROGGe, J.; BROWSE, J. Lipid Biosynthesis. The Plant Cell, v.7, p.957970, 1995.

OLIVEIRA, P.R.P. de; MASTROCOLA, M.A. Longevidade das sementes de gramineas forrageiras tropicais (1). Boletim da Indústria Animal, n.41, p. 203-211, 1984.

PARKER, W.B.; MARSHALL, L.C.; BURTON, J.D.; SOMERS, D.A. WYSE, D.L.; GRONWALD, J.W.; GENGENBACH, B.G. Dominant mutations causing alterations in acetyl-Coenzyme. A carboxylase confer tolerance to cyclohexanedione and aryloxyphenoxypropionate herbicides in maize. Proc. Natl. Acad. Sci. USA, n.87, p.7175-7179. 1990a.

PARKER, W.B.; SOMERS, D.A.; WYSE, D.L.; KEITH, R.A.; BURTON, J.D.; GRONWALD, J.W.; GENGENBACH, B.G. Selection and characterization of sethoxydim-tolerant maize tissue cultures. Plant Physiology, v.92. p.12201225, 1990b.

PEIXOTO, R.T.G.; AHRENS, D.C.; SAMAHA, M.J. Plantio direto: o caminho para uma agricultura sustentável. Ponta Grossa, PR: IAPAR, PRP?PG, 1997. 275p.

PILLMOOR, J.B.; CASELEY, J.C. The biochemical and physiological effects and mode of action of AC 222,293 againts Alopecurus myosuroides Huds. and Avena fatua L. Pesticide Biochemistry and Physiology, v.27, p.340-349, 1987.

PILMOOR, J.B.; LINDELL, S.D.; BRIGGS, G.G.; WRIGHT, K. In: RAGSDALE, N.N.; KEARNEY, P.C.; PLIMMER, J.R., Eigth International Congress of Pesticide Chemistry, Options 2000. American Chemical Society, Washington, D. C., p. 292-303. 1995. 
PONCHIO, J.A.R. Resistência de Bidens pilosa aos herbicidas inibidores da enzima acetolactato sintase. ESALQ-Piracicaba, 1997. 120p. (Tese Doutorado)- ESALQ - Universidade de São Paulo..

PONCHIO, J.A.R.; CHRISTOFFOLETI, P.J.; VICTORIA FILHO, R. ALS enxyme assay from Bidens pilosa biotypes of the Brazilian soybean areas to determine the sensitivety to imidazolinone and sulfonylurea herbicides. In: MEETING OF THE WEED SCIENCE SOCIETY OF AMERICA, 36, Nortfolk, 1996. Proceedings. p.79.

POST-BEITTENMILLER D.; JAWARSKI, J.G.; OHLROGGE, J.G. In vivo pools of free and acylated-acyl carrier proteins in spinach: Evidence for sites of regulation of fatty acid biosynthesis. Journal of Biological Chemistry, v. 266, p.1858-1865, 1991.

POWLES, S.B.; PRESTON, C. Herbicide cross resistance and multiple resistance in plants. Departament of crop protection. Waite Agricultural Research Institute. University of Adelaide. South Australia, 1995. 34 p.

POWLES, S.B; HOLTUM, J.A.M. Herbicide resistance in plants: Biology and biochemistry. Boca Raton: Lewis, 1994, 353 p.

PRESTON, C. Resistance to photosystem I disrupting herbicides. In: Herbicide Resistance in Plants (Powles, S. B., y Holtum, J. A. M., eds.). Lewis Publishers, Boca Raton, FL, p. 61-82. 1994.

RATTERMAN, D.M.; BALKE, N.E. 1989. Diclofop-methyl increases the proton permeability of isolated oat-root tonoplast. Plant Physiology, v. 91, p.756$765,1989$. 
RENDINA, A.R.; CRAIG-KENNARD, A.C.; BEAUDOIN, J.D.; BREEN, M.K. Inhibition of Acetyl-Coenzyme A Carboxylase by Two Classes of GrassSelective Herbicides. J. Agric. Food Chem. v.38, p.1282-1287, 1990.

RENDINA, A.R.; FELTS, J.M. Cyclohexanodione herbicides are selective and potent inhibitors of acetyl-CoA carboxylase from grasses. Plant Physiology, v.86, p.983-986, 1988.

RODRIGUES, B.N. e ALMEIDA, F.S. Guia de herbicidas. 4. ed. Londrina: IAPAR, 1998, 648p.

RODRIGUES, B.N. Influência da cobertura morta no comportamento dos herbicidas imazaquin e clomazone. Planta Daninha. v.11, n.1/2, p. 21-28, 1993.

RUBIM, B. Herbicide resistant weeds. The inevitable phenomenon: mechanisms, distribution and significance. Zeitschrift fur Pflanzenkrankheiten und Pflanzenshutz, v.15, p.17-32, 1996.

RUBIM, B. Herbicide resistance in weeds and crops, progress and prospects. In: CASELEY, J.C.; CUSSANS, G.W.; ATKIN, R.K.. Herbicide Resistance in Weeds and Crops. Butterworth-Heinemann Ed. Oxford, 1991. pp. 387414.

RYAN, G.F. Resistance of common groundsel to simazine and atrazine. Weed Science, v.18, p.614-616, 1970.

SAARI, L.L.; COTTEMAN, J.C.; THILL, D.C.. Resistance to acetolactate synthase inhibiting herbicides. In: Ferbicide Resistance in Plants (Powles, S. B., y Holtum, J.A.M., CRC Press, Boca Raton, pp. 83-140. 1994 
SASAKI, Y.; HAKAMADA, K.; SUAMA, Y.; NAGANO, Y.; FURUSAWA, I.; MATSUNO, R. Chloroplast-encoded protein as a subunit of acetyl-CoA carboxylase in pea plant.. J. Biol. Chem., v.268, p.25118-25123, 1993.

SASAKI, Y.; KONISHI, T.; NAGANO, Y. The compartmentation of acetylcoenzyme A carboxylase in plants. Plant Physiology, v.108, p. 445449, 1995.

SAWICKI, R.M. Definition, detection and documentation of insecticide resistance. In: FORD, M.G.; HOLLMAN, D.W.; KHAMBAY, B,. SAWICKI, R.M. Combating Resistance to Xenobiotics: Biological and Chemical Approaches. Ellis Horwood, Ed. Chichester, 1987. p.105-117.

SECOR, J.; CSÉKE, C.; OWEN, W.J. The discovery of the selective inhibition of acetyl coenzyme A carboxylase activity by two classes of graminicides. Proceedings of the Brighton Crop Protection Conference-Weeds, Brighton, England, v.1, p.145-154. 1989.

SECOR, J.; CZEKE, C. Inhibition of acetyl-CoA carboxylase activity by haloxyfop and tralkoxydim. Plant Physiology., v.86, p.10-12, 1988.

SEEFELDT, S.S.; FUERST, E.P.; IRZYK, G.P.; GEALY, D.R.; SHUKLA, A. HOFFMAN, D.; BREWSTER, B.D. Diclofop-resistant Avena fatua from the Willamette Valley of Oregon, Weed Science, v.44, p.776-781, 1996.

SEEFELDT, S.S.; GEARLY, D.R.; BREWSTER, B.D.; FUERST, E.P. Crossresistance of several diclofop-resistant wild oat (Avena fatua) biotypes from the Willamette Valey of Oregon. Weed Science, v.42, p.430-437, 1994.

SEEFELDT, S.S.; JENSEN, J.E.; FUERST, E.P. Log-logistc analysis of herbicide dose-response relationships. Weed Technology. v. 9, n.2, p. 218-227, 1995. 
SENDULSKY, T. Brachiaria: taxonomy of cultivated and native species in Brazil. Hoehnea, v.7, p.99-139, 1978.

SENTENAC H.; GRIGNON, C. Effect of $\mathrm{H}^{+}$excretion on the surface $\mathrm{pH}$ of corn cells evaluated by using weak acid influx as a $\mathrm{pH}$ proble. Plant Physiology, v.84, p.1367-1372, 1987.

SHANER, D.L. Herbicide resistance in North America: History, circunstances of development and current situation. In: De PRADO, R.; JRRIN, J.; GARCIATORRES, L. eds. Weed and crop resistance to herbicides, Kluwer, Dordrecht. p.29-38. 1997.

SHANER, D.L. Studies on the mechanism and genetics of resistance: their contribution to herbicide resistance management. Proc. Brighton Crop Prot. Conf.-Weeds, p.537-545. 1995.

SHANER, D.L.; SIMCOX, P. D.; ROBSON, P.A. et al. AC - 222,293 translocation and metabolic selectivity. In: PROC. BRITISH PLANT PROT. CON. p. 333-339, 1983.

SHERMAN, T.D.; VAUGHN, K.C.; DUKE, S.O. Mechanism of action and resistance to herbicides. In: DUKE, S.O. (Ed.) Herbicides Resistant Crops. Boca Raton: CRC press, 1996. p.14-28.

SHIMABUKURO, R.H. ; HOFFER, B.L.. Effect of Diclofop on the Membrane Potentials of Herbicide-Resistent and Susceptible Annual Ryegrass Root Tips. Plant Physiology, v.98, p.1415-1422, 1992.

SHIMABUKURO, R.H. Selectivity and Mode of Action of the Postemergence Herbicide Diclofop-Methyl. Plant Growth Regul. Soc. Am. Q., v.18, p.37$54,1990$. 
SHIMABUKURO, R.H.; HOFFER, B.L. Diclofop action: physiological evidence for reversible binding to a receptor-like molecule. Weed Sciences Society of America. Abstracts 182. 1988.

SHIMABUKURO, R.H.; HOFFER, B.L. Perturbation of transmembrane proton gradient and inhibition of fatty acid metabolism: Their roles in the mechanism of action of ficlofop-methyl. Weed Science Society of America. Abstract no. 176. 1990.

SHIMABUKURO, R.H.; HOFFER, B.L. Perturbation of the transmembrane proton gradient and resistance to AOPP herbicides. In: De PRADO, R.; JORRIN, J.; GARCIA-TORRES, L. eds. Weed and crop resistance to herbicides, Kluwer, Dordrecht. p.71-80. 1997.

SHIMABUKURO, R.H.; HOFFER, B.L.. Metabolism of diclofop-methyl in susceptible and resistant biotypes of Lolium rigidum. Pesticide Biochemistry and Physiology, v.39, p.251-258, 1991

SHIMABUKURO, R.H.; WALSH, W.C.; HOERAUF, R.A. Metabolism and selectivity of diclofop-methyl in wild oat and wheat. J. Agric. Food Chem., v.27, p.615-623, 1979.

SHUKLA, A.; DUPONT, S.; DEVINE, M.D. Resistance to ACCase-inhibitor herbicides in wild oat: evidence for target site-based resistance in two biotypes from Canada. Pesticide Biochemistry and Physiology, v.57, p.147-155, 1997.

SILVERTOWN, J.W. Introduction to plant population ecology. New York: Longman. 2.ed. 1987. 220p. 
SINDAG - Sindicato da indústrias de defensivos agricolas - Boletim 99, divulgado por e-mail.

SMEDA, R.J.; BARENTINE, W.L.; SNIPES, C.E. Johnsongrass (Sorghum halepense (L.) Pers.) resistence to postemergence grass herbicides. Weed Science Society of America. Abstract no. 53. 1993.

STOLTENBERG, D.E.; WIEDERHOLT, R.J. Giant foxtail (Setaria faberi Herm.) resistance to acetylCoA carbozylase inhibitors. Weed Science Society of America. Abstract no. 183. 1993.

STOLTENBERG, D.E.; WIEDERHOLT, R.J. Giant foxtail (Setaria faberi) resistance to aryloxyphenoxypropionate and cyclohexanedione herbicides. Weed Science, v.43, p.527-535, 1995.

STOLTENBERG, D.E.; WYSE, D.L. Regrowth of Quackgrass (Agropyron repens) Following Postemergence Applications of Haloxyfop and Sethoxydim. Weed Science. v. 34, p.664-668, 1986.

STUMPF, P.K. The biosynthesis of saturated fatty acids. In: STUMPF, P. K.; CONN, E.E. eds The biochemistry of plants. Vol. 9: Lipids: Structure and Funcytion, v.9, p.121-157. Academy Press, New York. 1987.

TARDIF, F.J.; POWLES, S.B. Herbicide multiple-resistance in a Lolium rigidum biotype is endowed by multiple mechanisms: isolation of a subset with resistant acetyl-CoA carboxylase. Physiologia Plantarum, v.91, p.488494, 1994.

THAI, K.M., JANA, S.; NAYLOR, J.M. Variability for response to herbicides in wild oat (Avena fatua) populations. Weed Science, v.33, p.829-835. 1985. 
UCHIYAMA, M.; WASHIO, N.; IKAI, T.; IGARASHI, H.; SUZUKI, K. Stereospecific responses to (R)-(+)- and (S)-(-)-quilazofop-ethyl in tissues of several plants. Journal Pesticide Science, v.11, p.459-467, 1986.

VALVERDE, B.E.; CHAVES, L.; GONZALEZ, J.; GARITA, I. Field-evolved imazapyr resistance in Ixophorus unisetus and Eleusine indica in Costa Rica. Proc. Brighton Crop Prot. Con. Weeds, p. 557-566. 1993.

VIDAL, R.A.; FLECK, N.G. Three weed species with confirmed resistance to herbicides in Brazil. In: MEETING OF THE WEED SCIENCE OF AMERICA, 1997. Abstracts. p. 100.

VOOL, E.; GAZZIERO, D.L.P.; QUINA, E.; KRYZANOWSKI, F.C. Avaliação físiológica de sementes de Brachiaria plantaginea com procedimentos da superação de dormência. Revista Brasileira de Sementes. v.18. p.186192. 1996.

WAKIL, S.J.; STOOPS, J.K.; JOSHI, V.C. Fatty acid synthesis and its regulation. Annu. Rev. Biochem., v.52, p.537-579, 1983.

WALKER, K.A.; RIDLEY, S.M.; LEWIS, T. \& HARWOOD, J.L. Action of Aryloxyphenoxy Carboxylic Acids on Lipid Metabolism. Weed Science. v.4, p. 71-84, 1989.

WALKER, K.A.; RIDLEY, S.M.; LEWIS, T.; HARWOOD, J.L. Fluazifop, a grass selective herbicide which inhibits acetyl-CoA carboxylase in sensitive plants species. Biochemistry Journal, v.254, p.307-310, 1988.

WEED SCIENCE SOCIETY OF AMERICA. Herbicide handbook, $6^{\text {th }}$ Edition. Champaign :WSSA. 1989. 515p. 
WELLER, S.C. Herbicide resistance in weeds: In: Herbicide action: an intensive course on activity, selectivity, behavior and fate of herbicides in plants and soils. Purdue University. West Lafayette, 1992. $666 \mathrm{p}$.

WHITEHEAD, C.W.; SWITZER, C.M. The differencial response of strains of wild carrot to 2,4-D and related herbicides. Canadian Journal of Plant Science. v. 43, p.255-262, 1962.

WHYTE, R.O.; MOIR, T.R.G.; COOPER, J.P. Las gramineas en la agricultura. Roma, FAO, 1975. 464p.

WIEDERHOLT, R.J.; STOLTENBERG, D.E. Cross-resistance of a large crabgrass (Digitaria sanguinalis) accession to aryloxyphenypropionate and cyclohexanedione herbicides. Weed Technology, v.9, n.3, p.518-524, 1995.

WOODBURN, A.T. Global and regional market estimates. In: Allan Woodburn Associates, Agrochemicals-Executive Review, 6th edition, , Edinburgh. p.12-13. 1995.

WRIGHT, J.P.; SHIMABUKURO, R.H. Effects of diclofop and diclofop-methyl on the membrane potentials of wheat and oat coleoptiles. Plant Physiology, v. 85, p.188-193, 1987.

WRIGHT, J.P.; SHIMABUKURO, R.H. Effects of diclofop and diclofop-methyl on the membrane potentials of wheat and oat coleoptiles. Plant Physiology, v.85, p.188-193, 1987. 
WSSA. N.E. HUMBURG, S.R. COLBY, R.G. LYM, E.R. HILL, W.J. MCAVOY, L.M. KITCHEN Y R. PRASAD, eds., Herbicide Handbook of the Weed Science Society of America, $6^{\text {th }}$ edition, Weed Science Society of America, Champaign, Illinois. 1989. 301p.

ZADOKS, J.C.. The cost of the change in plant protection. Journal Plant. Protection In the Tropics, v.9, n.2, p.151-159. 1992. 
ANEXOS 


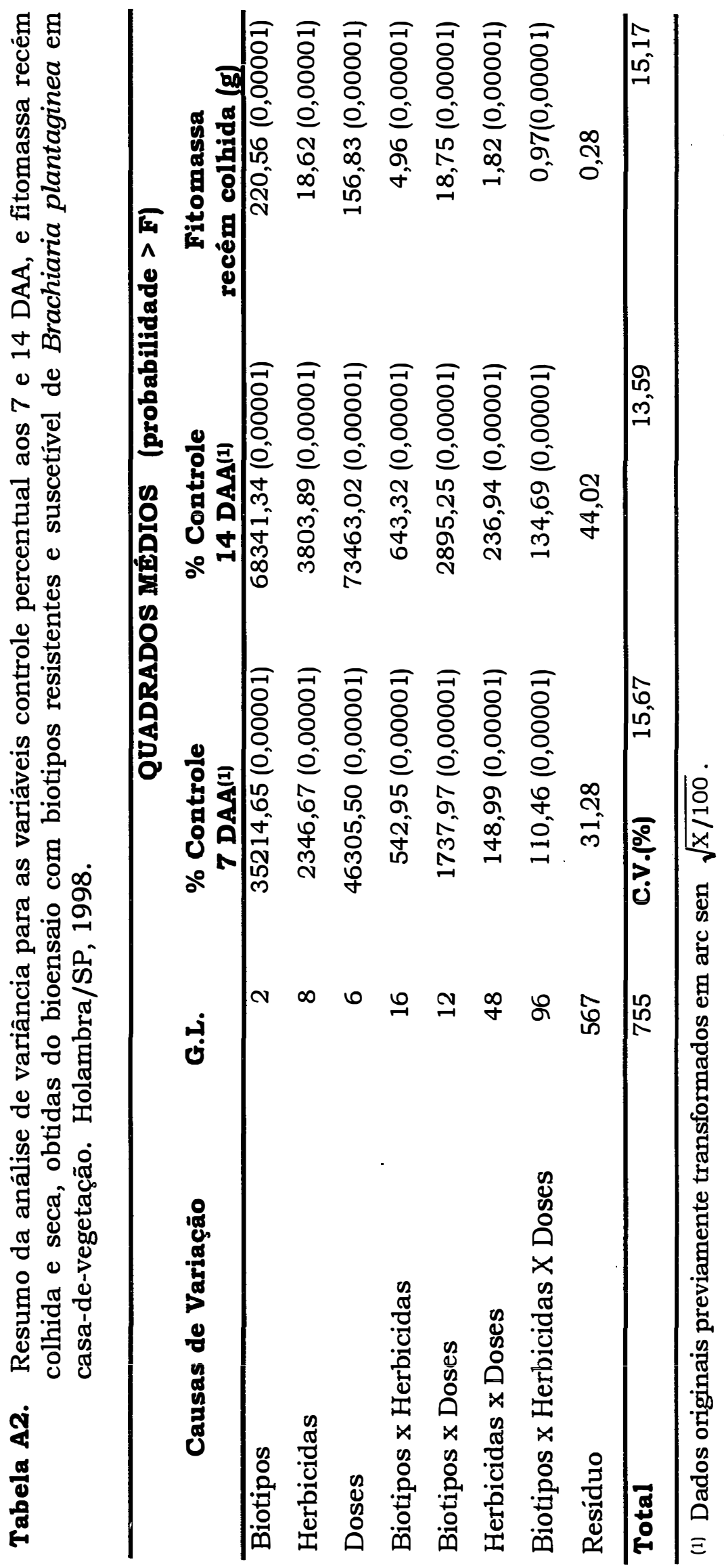




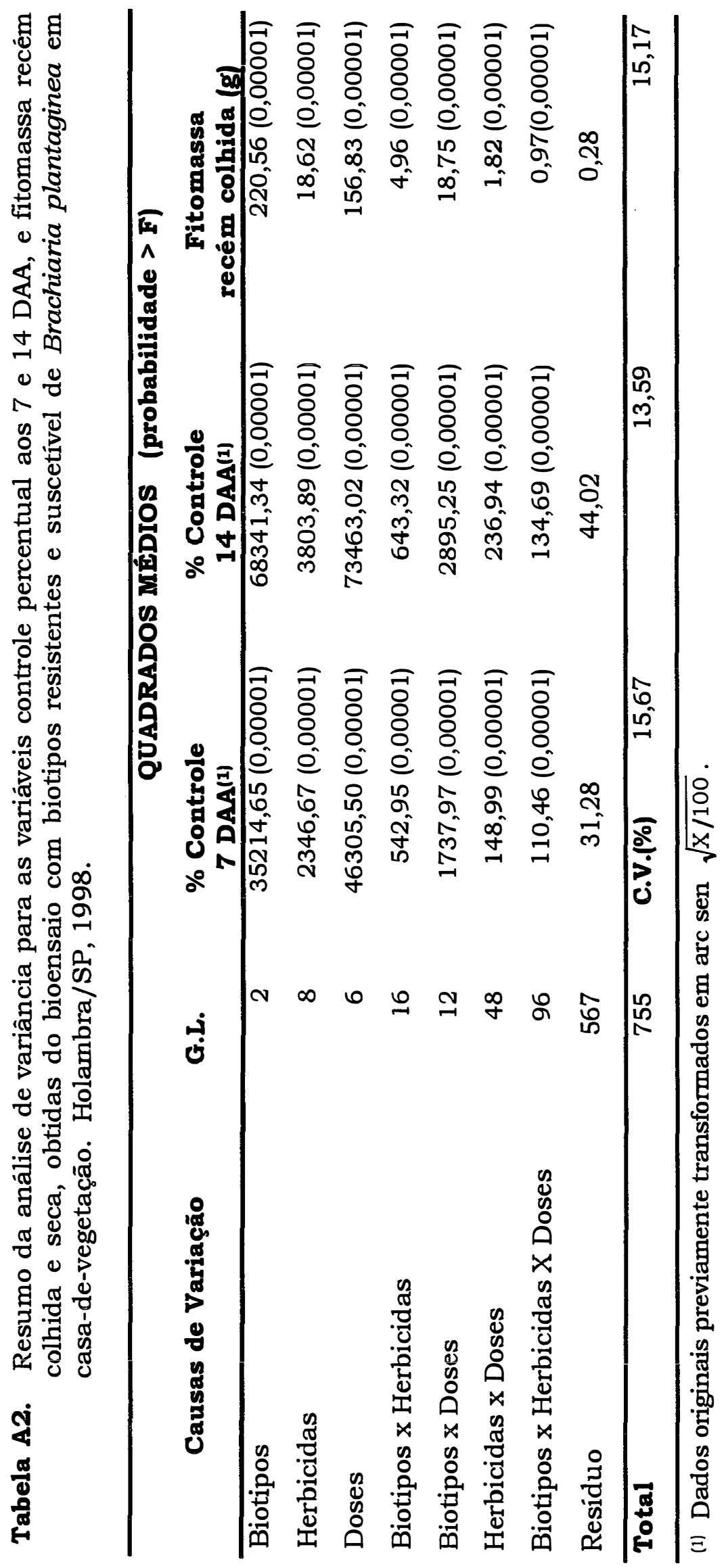




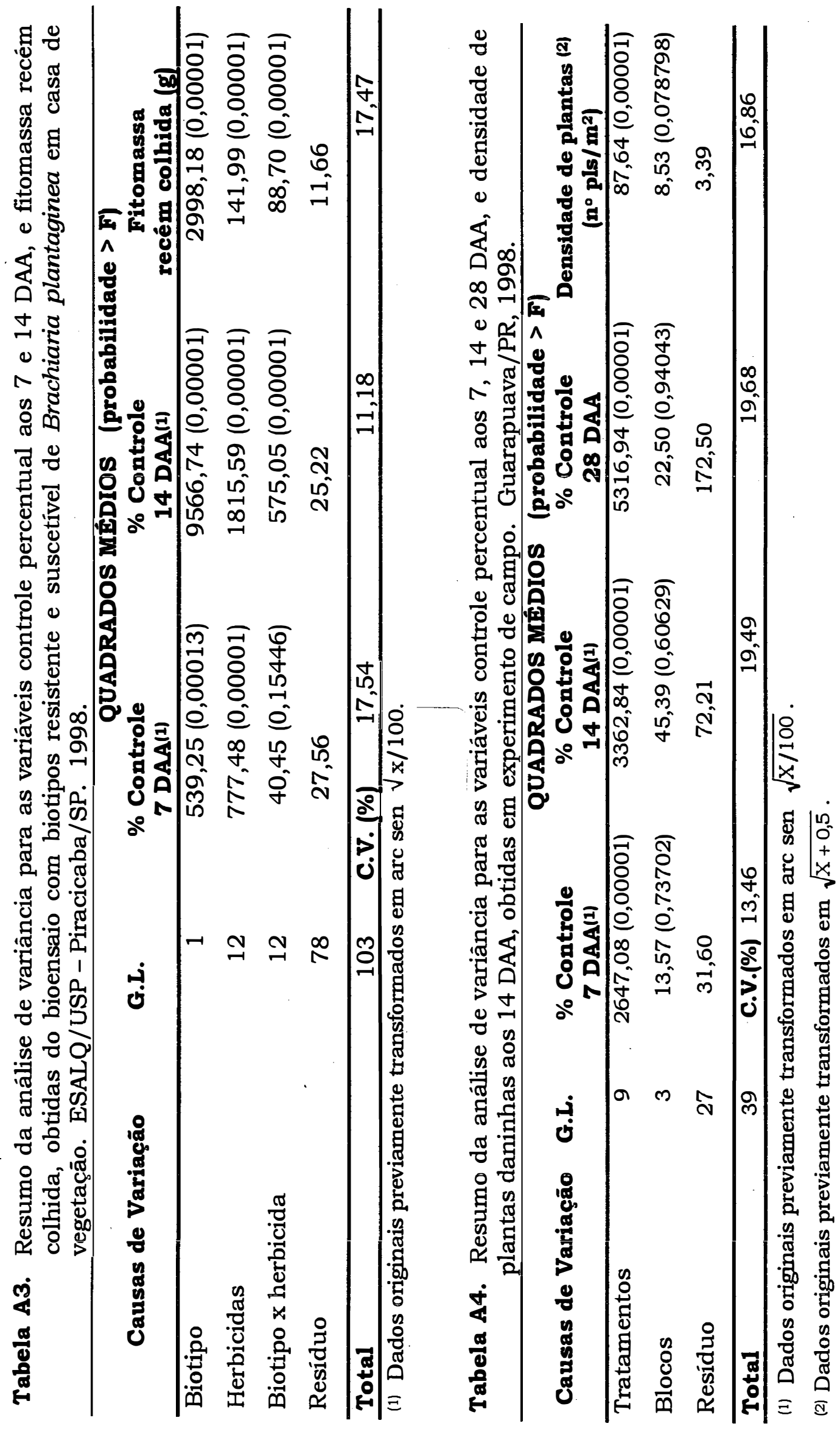

